
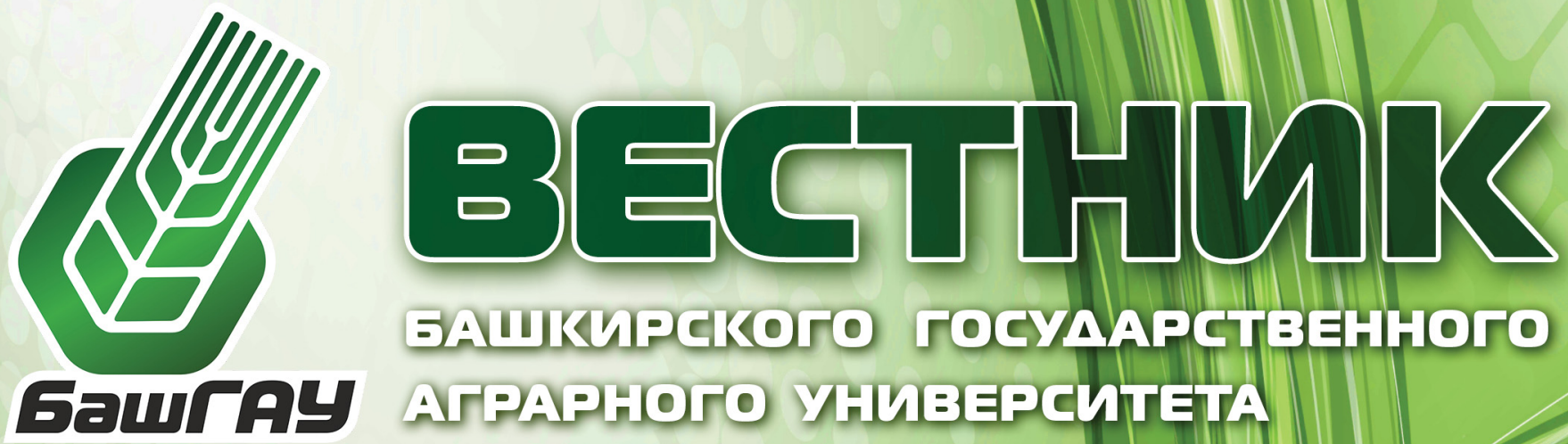

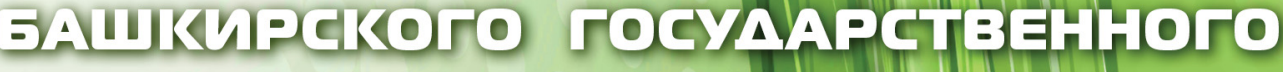

\section{$15+$}




\section{ПОДПИСНОЙ ИНДЕКС \\ В КАТАЛОГЕ «ИЗДАНИЯ ОРГАНОВ \\ НАУЧНО-ТЕХНИЧЕСКОЙ ИНФОРМАЦИИ" \\ ОАО АГЕНТСТВО "РОСПЕЧАТЬ" \\ 66024}

Катахожная цена подписки

за помугодие - 700 рубцей

Выходит один раз в квартал 
Научный журнал

Учредитель:

Башкирский государственный аграрный университет

Основан в 2001 г.
Вестник

Башкирского государственного аграрного университета

$16+$

Журнал входит в Перечень рецензируемых научных изданий, в которых должны быть опубликованы основные научные результаты диссертаций на соискание учёной степени кандидата наук, на соискание учёной степени доктора наук

\section{СОДЕРЖАНИЕ}

Агрономия

Ветеринария и Зоотехния
DOI: $10.31563 / 1684-7628-2019-51-3-6-9$

И.Е Анищенко, О.Ю. Жигунов, Л.М. Ишбирдина

Некоторые малоиспользуемые пряно-ароматические растения в Башкирском Предуралье. 6

DOI: $10.31563 / 1684-7628-2019-51-3-10-13$

Н.Н. Зайцева, Н.А. Фадеева, О.А. Васильев Эффективность применения твердых продуктов биогазовой установки на нефтезагрязненных почвах 10

DOI: $10.31563 / 1684-7628-2019-51-3-14-19$

И.Г. Сабирзянов, К.М. Габдрахимов, Л.Н. Блонская Депонирование углерода растениями в Республике Башкортостан 14

DOI: 10.31563/1684-7628-2019-51-3-20-26

Д.В. Чикишев, Н.В. Абрамов, Н.С. Ларина, С.В. Шерстобитов Влияние азотных удобрений на аминокислотный состав зерна яровой пшеницы

DOI: 10.31563/1684-7628-2019-51-3-26-31

Е.А. Ажмулдинов, Ю.Н. Чернышенко, М.Г. Титов Физиологическое состояние и продуктивность животных при воздействии теплового стресса. 26

DOI: 10.31563/1684-7628-2019-51-3-31-35

А.В. Альдяков, С.Г. Кондручина Висцеральная блокада телят при гастроэнтерите 31

DOI: 10.31563/1684-7628-2019-51-3-36-41

Г.З. Бронникова, Е.Н. Сковородин

Ультраструктура и кариоцитометрия гепатоцитов перепелов. 36 
DOI: $10.31563 / 1684-7628-2019-51-3-42-47$

E.В. Егорашина, Р.В. Тамарова

Использование маркерной селекции

в племенной работе со стадом молочного скота

разных пород

DOI: 10.31563/1684-7628-2019-51-3-48-52

Д.Н. Латфуллин, Р.М. Ахмадеев, Н.Р. Мифтахов, Х.Н. Макаев

Результаты исследований напряженности иммунитета

крупного рогатого скота, вакцинированного против

бешенства, в Республике Татарстан и приграничных

с ней районах Республики Башкортостан 48

DOI: $10.31563 / 1684-7628-2019-51-3-52-58$

А.И. Любимов, Ю.В. Исупова

Интенсивность роста и развития ремонтных телок

черно-пестрой породы в зависимости

от происхождения

DOI: $10.31563 / 1684-7628-2019-51-3-58-63$

T.A. Русских, В.А. Бычкова

Влияние возраста первого осеменения

на продуктивное долголетие коров черно-пестрой

и холмогорской породы .... .58

DOI: 10.31563/1684-7628-2019-51-3-64-69

B.А. Тараненко, С.Н. Косников

Оценка и перспективы развития

молочной промышленности в Краснодарском крае 64

DOI: 10.31563/1684-7628-2019-51-3-69-74

М.Б. Улимбашев

Типы телосложения голштинского скота в зависимости от удельно-массового коэффициента

Процессы и машины агроинженерных систем
DOI: $10.31563 / 1684-7628-2019-51-3-74-82$

Р.С. Аипов, Д.С. Леонтьев, В.Ю. Кабашов

Экспериментальное исследование линейного электропривода двухножевого режущего аппарата жатки зерноуборочного комбайна 74

DOI: 10.31563/1684-7628-2019-51-3-83-92

Л.П. Андрианова, В.Ю. Кабашов, Д.С. Хайрисламов Индикативные показатели надежности SAIFI и SAIDI сельских электрических сетей с интеллектуальными секционирующими реклоузерами

DOI: 10.31563/1684-7628-2019-51-3-92-99

М.В. Борисова, А. Ю. Титов, В. В. Новиков, В. В. Коновалов Влияние количества воздействий лопастей тихоходного смесителя на качество приготавливаемой смеси. 92 
DOI: $10.31563 / 1684-7628-2019-51-3-99-106$

А.В. Неговора, Р.Ж. Магафуров, А.И. Низамутдинов Обоснование температуры рабочей жидкости при испытании дизельных инжекторов.

DOI: 10.31563/1684-7628-2019-51-3-106-114

И.Р. Кафиев, П.С. Романов, И.П. Романова, Р.Р. Галиуллин

Методика распознавания нечетких ситуаций при управлении сельскохозяйственными мобильными роботами .

DOI: 10.31563/1684-7628-2019-51-3-114-120

Э.Р. Хасанов, Д.И. Маскулов, Р.З. Мусин

Обоснование показателей качества работы скарификатора семян козлятника

РОССИЙСКИЙ ИНДЕКС НАУЧНОГО ЦИТИРОВАНИЯ Science Index

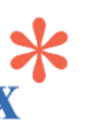

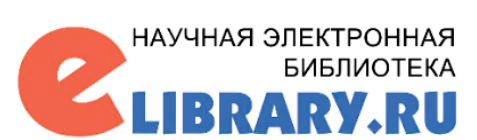

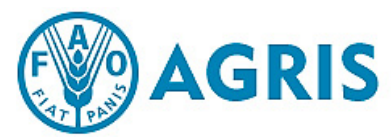

Полные тексты статей доступны на сайте электронной научной библиотеки eLIBRARY.RU: http://elibrary.ru и на сайте www.bsau.ru

\section{DOI журнала: $10.31563 / 1684-7628$ \\ DOI выпуска: 10.31563/1684-7628-2019-51-3}

Главный редактор: И.И. Габитов, д-р техн. наук, профессор

Заместители главного редактора: Р.Р. Султанова, д-р с.-х. наук, профессор

И.В. Чудов, д-р биол. наук, доцент

Редакционная коллегия: Р.М. Баширов, член-корр. АН РБ, д-р техн. наук, профессор; В.В. Гимранов, д-р вет. наук, профессор; М. Грингс, проф., д-р сельского хозяйства (Германия); Б. Деген, доктор, профессор (Германия); Ф.С. Амиршоев, д-р биол. наук, профессор (Таджикистан); Р.Р. Исмагилов, член-корр. АН РБ, д-р с.-х. наук, профессор; К. Канненберг, д-р экон. наук (Польша); Ж.К. Керималиев, д-р вет. наук (Кыргызстан); Д.Д. Лукманов, д-р экон. наук, доцент; С.Г. Мударисов, член-корр. АН РБ, д-р техн. наук, профессор; Х.Х. Тагиров, д-р с.-х. наук, профессор; Н.К. Мазитов, д-р с.-х. наук, профессор, член-корр. РАН (Республика Татарстан); А.А. Стекольников, д-р вет. наук, профессор, академик РАН (Санкт-Петербург); И.О. Чанышев, д-р с.-Х. наук; Ю.А. Янбаев, д-р биол. наук, профессор

Адрес учредителя, издателя и редакции: 450001, Республика Башкортостан, г. Уфа, ул. 50-летия Октября, д. 34 Тел./факс: (347) 228-15-11

E-mail: vestnik-bsau@mail.ru www.vestnik.bsau.ru

ISSN 1684-7628

\section{Редактор: H.A. Hиколаенко}

Технический и художественный редактор: A.E. Aepeeвa

Подписано в печать 20.09.2019. Формат бумаги $60 \times 84 / 8$

Усл.-печ. л. 13,95. Бумага офсетная. Гарнитура «Таймс».

Печать трафаретная. Заказ 1292. Тираж 300 экз.

РИО ФГБОУ ВО БашкирскиЙ ГАУ

450001, г. Уфа, ул. 50-летия Октября, 34, каб. 109

(C) ФГБОУ ВО Башкирский ГАУ, 2019
Журнал зарегистрирован

в Федеральной службе по надзору в сфере связи, информационных технологий и массовых коммуникаций (Роскомнадзор), регистрационный номер ПИ № ФС77-67713 от 10.11.2016 
Scientific journal

\section{Constituter:}

Bashkir

State

Agrarian

University

Founded in 2001 year Issued quarterly

\section{Vestnik}

\author{
Bashkir State \\ Agrarian University
}

№ 3 (51), 2019

\section{CONTENTS}

Agronomics

Veterinary and animal science
I. Anishchenko, O. Zhigunov, L. Ishbirdina

Rarely used aromatic plants in the Bashkir Cis-Urals 6

N. Zaytseva, N. Fadeeva, O. Vasilyev

Efficiency of application of solid products of biogas installation on oil-polluted soils

I. Sabirzyanov, K. Gabdrakhimov, L. Blonskaya

Carbon sequestration in plants

in the Republic of Bashkortostan.

D. Chikishev, N. Abramov, N. Larina. S. Sherstobitobov

Effect of nitrogen fertilizers on amino acid composition

of spring wheat grain

E. Azhmuldinov, Yu. Chernyshenko, M. Titov

Physiological state and productivity of animals

under thermal stress

V. Aldyakov, S. Kondruchina

Visceral procaine blockade at gastroenteritis in calves

G. Bronnikova, E. Skovorodin

Ultrastructure and hepatocyte karyocytometry of quails

E. Egorashina, R. Tamarova

Using a marker-based selection in breeding

of dairy cattle of different breeds

D. Latfullin, R. Akhmadeev, N. Miftahov, Kh. Makaev

Study results of immune response intensity in cattle vaccinated against rabies in the Republic

of Tatarstan and border areas of the Republic of Bashkortostan

A. Lyubimov, Yu. Isupova

Growth and development of black-and-white replacement

heifers depending on the origin

T. Russkikh, V. Bychkova

Influence of the age at the first insemination

on the productive longevity of black and white

and kholmogory cows 
V. Taranenko, S. Kosnikov

Dairy industry in Krasnodar territory:

assessment and development prospects

M. Ulimbashev

Holstein cattle constitution types depending

on the specific weight rate.

Processes and machinery of agroengineering systems

R. Aipov, D. Leontiev, V. Kabashov

Experimental study of linear electric drive

of the double-breed cutting machine

of the grain combine header

L. Andrianova, V. Kabashov, D. Khairislamov

SAIFI and SAIDI indicative reliability figures

of rural electric networks with smart island reclosers

M. Borisova, A. Titov, V. Novikov, V. Konovalov Influence of a number of impacts of low-speed

mixer blades on concrete quality being prepared

A. Negovora, R. Mugafarov, A. Nizamutdinov

Substatiation of the working fluid temperature

when testing diesel injectors

I. Kafiev, P. Romanov, I. Romanova, R. Galiullin

Recognition methods of fuzzy situations

to manage mobile robots in farming....

E. Khasanov, D. Maskulov, R. Musin

Substantiation of work quality indicators

of the eastern galega seeds scarificator.

Editor-in-chief: I. Gabitov, Dr. tech. sci., Professor

Deputy Editor-in-chief: R. Sultanova, Dr. agr. sci.,

I. Chudov, Dr. biol. sci.

Editorial board: R. Bashirov, Corresponding Member AS RB, Dr. tech. sci., Professor; V. Gimranov, Dr. vet. sci., Professor; M. Grings, Prof. Dr. agr. habil. (Germany); B. Degen, Dr., Professor (Germany); F. Amirshoyev, Dr. biol. sci., Professor (Tajikistan); R. Ismagilov, Corresponding Member AS RB, Dr. agr. sci., Professor; K. Kannenberg, Dr. econ. sci. (Poland); Z. Kerimaliev, Dr. vet. sci. (Kyrgyz Republic); S. Mudarisov, Corresponding Member AS RB, Dr. tech. sci., Professor; H. Tagirov, Dr. agr. sci., Professor; N. Mazitov, Dr. agr. sci., Professor, Corresponding Member of the Russian Academy of Sciences (Republic of Tatarstan); A. Stekolnikov, Dr. vet. sci., Professor, Academician of the Russian Academy of Sciences (St. Petersburg); I. Chanyshev, Dr. agr. sci.; Y. Yanbaev, Dr. biol. sci., Professor

Editorial Office Address:

34, 50-letia October St.,

Ufa, 450001

Tel.: (347) 228-15-11

E-mail: vestnik-bsau@mail.ru

ISSN 1684-7628
Publishing house FSEI HE Bashkir SAU

Printed FSEI HE Bashkir SAU

Editor: N. Nikolaenko

Technical editor, corrector, make-up: A. Dereeva

(C) FSEI HE Bashkir SAU, 2019 
УДК 635.7

DOI: $10.31563 / 1684-7628-2019-51-3-6-9$

И.Е Анищенко, О.Ю. Жигунов, Л.М. Ишбирдина

\section{НЕКОТОРЫЕ МАЛОИСПОЛЬЗУЕМЫЕ ПРЯНО-АРОМАТИЧЕСКИЕ РАСТЕНИЯ В БАШКИРСКОМ ПРЕДУРАЛЬЕ}

\section{Ключевые слова: пряно-ароматические растения; морфометрические параметры; сезонный ритм развития; успешность интродукции.}

Введение. Пряно-ароматические растения известны человеку с древних времен. Потребность в пряно-ароматических растениях до сих пор постоянно растет. Они необходимы в различных отраслях промышленности (косметической, парфюмерной, фармацевтической), и прежде всего - в пищевой. Это связано с наличием в них минеральных солей, витаминов, эфирных масел, гликозидов, терпенов, терпеноидов и др. соединений. Пряности улучшают вкус пищевых продуктов [1]. Республика Башкортостан отличается богатством и разнообразием растительности. Более 200 видов дикорастущих растений республики представляют интеpec с точки зрения использования их в качестве лекарственного и пряно-ароматического сырья. Интродукционное изучение местных и инорайонных растений позволяет выявить биологические особенности растений, изучить ритм развития и рекомендовать наиболее перспективные виды для выращивания в Башкирском Предуралье. Особой популярностью пользуются такие пряные растения семейства Apiaceae Lindl. (Сельдерейные), как петрушка, укроп, кориандр, сельдерей, фенхель и др. Но это семейство содержит не менее ценные, к сожалению, еще малоиспользуемые виды, такие как Silaum silaus (L.) Schinz et Thell (морковник обыкновенный) и Levisticum officinale Koch. (любисток лекарственный).

Цель исследований - изучение особенностей сезонного ритма роста и развития, морфометрических показателей и оценки успешности интродукции двух малоиспользуемых пряноароматических видов семейства Apiaceae Silaum silaus и Levisticum officinale в условиях культуры.

Условия и методы исследований. Исследования проводились в Южно-Уральском ботаническом саду с 2001 г.

Климат г. Уфы континентальный, характерный для северных лесостепей. Среднегодовая температура воздуха $+3,8^{\circ} \mathrm{C}$, а сумма осадков -
589 мм. Отрицательные средние месячные температуры характерны для пяти месяцев в году, отдельные заморозки возможны во все месяцы, кроме июля и августа. Средняя январская температура $-14,6^{\circ}$. Абсолютный минимум $-54^{\circ}$. Средняя температура июля равна $19^{\circ}$, абсолютный максимум достигает $40^{\circ}$. Безморозный период длится около 140 дней [3].

В работе нами использованы методики И.Н. Бейдеман [4], Н.В. Трулевич [5], статистическая обработка фактического материала проведена по Г.Н. Зайцеву [6], оценка успешности интродукции по Р.А. Карписоновой [7] и Л.И. Томиловой [8].

Результаты исследований. Изученные виды имеют большое пищевое значение и обладают лечебными свойствами благодаря наличию в своем составе эфирных масел, флавоноидов, алкалоидов, витаминов, кумаринов и др. Морковник положительно влияет на систему кровообращения, мочевыделительную систему, обладает тонизирующим, противовоспалительным и общеукрепляющим действием. Любисток имеет желчегонное, седативное, спазмолитическое, антибактериальное действие, улучшает пищеварение [2].

Способность прохождения полного цикла сезонного развития изучаемого вида растений является основным критерием успешности его интродукции. Весеннее отрастание у Silaum silaus и Levisticum officinale происходит в конце апреля, в фазу бутонизации растения вступают во второй декаде июня, массовое цветение у любистока лекарственного начинается в первой декаде июля, у морковника обыкновенного - во второй декаде июля. Период цветения обоих видов в среднем составляет 35 дней. Созревание семян у любистока лекарственного начинается в конце августа, у морковника обыкновенного - в середине сентября. Результаты измерений морфологических особенностей изученных видов приведены в таблице 1. 
Таблица 1 Морфологические показатели морковника обыкновенного и любистока лекарственного

\begin{tabular}{|c|c|c|c|c|c|}
\hline \multirow{2}{*}{\multicolumn{2}{|c|}{ Параметр }} & \multicolumn{2}{|c|}{ Silaum silaus } & \multicolumn{2}{|c|}{ Levisticum officinale } \\
\hline & & $\mathrm{M} \pm \mathrm{m}$ & $\mathrm{C}_{\mathrm{v}}, \%$ & $\mathrm{M} \pm \mathrm{m}$ & $\mathrm{C}_{\mathrm{v}}, \%$ \\
\hline \multicolumn{2}{|l|}{ Высота растения, см } & $123,6 \pm 1.31$ & 2,8 & $168,4 \pm 0,87$ & 1,4 \\
\hline \multicolumn{2}{|l|}{ Толщина стебля, см } & $0,7 \pm 0,02$ & 7,2 & $1,7 \pm 0,05$ & 9,7 \\
\hline \multicolumn{2}{|c|}{ Длина прикорневых листьев с черешком, см } & $58,6 \pm 1,72$ & 7,8 & $67,4 \pm 2.19$ & 8,6 \\
\hline \multicolumn{2}{|c|}{ Ширина прикорневых листьев, см } & $15,6 \pm 0,43$ & 7,3 & $24,7 \pm 0,57$ & 6,1 \\
\hline \multicolumn{2}{|c|}{ Длина стеблевых листьев с черешком, см } & $32,4 \pm 0,84$ & 6,9 & $31,6 \pm 0,38$ & 12,6 \\
\hline \multicolumn{2}{|c|}{ Ширина стеблевых листьев, см } & $17,0 \pm 0,38$ & 5,9 & $12,6 \pm 0,30$ & 6,3 \\
\hline \multicolumn{2}{|c|}{ Число прикорневых листьев, шт. } & $45,7 \pm 0,94$ & 5,5 & $15,9 \pm 0,96$ & 16,0 \\
\hline \multicolumn{2}{|c|}{ Число листьев на генеративном побеге, шт. } & $7,0 \pm 0,38$ & 14,3 & $4,3 \pm 0,18$ & 11,4 \\
\hline \multicolumn{2}{|c|}{ Число генеративных побегов, шт. } & $10,0 \pm 0,38$ & 10,0 & $3,4 \pm 0,20$ & 15,6 \\
\hline \multirow{2}{*}{$\begin{array}{l}\text { Число зонтиков } \\
\text { на генеративном побеге, шт. }\end{array}$} & I пор. & $6.1 \pm 0.40$ & 17,4 & $8,3 \pm 0,42$ & 13,4 \\
\hline & II пор. & $15,4 \pm 0,72$ & 12,3 & $16,1 \pm 1,20$ & 19,7 \\
\hline \multirow{2}{*}{$\begin{array}{l}\text { Число зонтичков } \\
\text { в зонтике, шт. }\end{array}$} & I пор. & $14,0 \pm 0,62$ & 11,7 & $14,1 \pm 0,40$ & 7,6 \\
\hline & II пор. & $11,0 \pm 0,31$ & 7,4 & $10,6 \pm 0,20$ & 5,1 \\
\hline \multirow{2}{*}{ Диаметр зонтика, см } & I пор. & $4,3 \pm 0,07$ & 4,2 & $5,3 \pm 0,08$ & 3,7 \\
\hline & II пор. & $1,8 \pm 0,04$ & 5,4 & $2,1 \pm 0,08$ & 10,3 \\
\hline \multirow{2}{*}{$\begin{array}{l}\text { Число цветков } \\
\text { в зонтике, шт. }\end{array}$} & I пор. & $17,6 \pm 0,37$ & 5,6 & $27,4 \pm 0,53$ & 5,1 \\
\hline & II пор. & $13,4 \pm 0,43$ & 8,4 & $14,9 \pm 1,08$ & 19,2 \\
\hline \multirow{2}{*}{$\begin{array}{l}\text { Диаметр зонтичка } \\
\text { в зонтике, см }\end{array}$} & I пор. & $0,5 \pm 0,02$ & 9,8 & $1,0 \pm 0,04$ & 10,0 \\
\hline & II пор. & $0,3 \pm 0,02$ & 16,3 & $0,4 \pm 0,02$ & 15,1 \\
\hline
\end{tabular}

Морковник обыкновенный в природе встречается в Скандинавии и других странах Европы. В России - в степных и лесостепных районах южной полосы европейской части, на Кавказе, в Сибири. В Республике Башкортостан встречается в степях, на солончаках, солонцах, среди степных кустарников, окраинах полей, вдоль дорог $[1,9]$. Это многолетнее травянистое растение, которое в условиях культуры в ботаническом саду г. Уфы достигает высоты 123,6 \pm 1,31 см. Листья трижды и четырежды перисторассеченные, в очертании яйцевидные. Прикорневые листья крупные на длинных черешках, $58,6 \pm 1,72$ см длиной и $15,6 \pm 0,43$ см шириной. Стеблевые листья более мелкие, $32,4 \pm 0,84 \mathrm{~cm}$ длиной и $17,0 \pm 0,38$ см шириной, менее рассеченные. Прикорневые листья многочисленные $(45,7 \pm 0,94$ шт.) по сравнению со стеблевыми (7,0 \pm 0,38 шт.). Цветы мелкие бледно-желтые, собраны в сложные зонтики. Любисток лекар- ственный произрастает в горах южной части Ирана, почти по всей Европе и Северной Америке. В одичавшем виде встречается на Кавказе и европейской части России, в Башкортостане [10].

Многолетнее травянистое растение, в культуре достигает 168,4 \pm 0,87 см высоты. Стебель прямой, полый, голый, бороздчатый, вверху ветвистый, толщиной $1,7 \pm 0,05$ см. Листья перисторассеченные, темно-зеленые, блестящие. Нижние листья крупные $(67,4 \pm 2,19$ см длиной и $24,7 \pm 0,57$ см шириной) на длинных черешках, стеблевые листья сидячие, влагалищные, $31,6 \pm 0,38$ см длиной и $12,6 \pm 0,30$ см шириной. Цветки беловато-желтоватые, собраны в соцветие - сложный зонтик. Из двух изученных видов пряно-ароматических растений любисток лекарственный отличается более высокими показателями по высоте растений и толщине стебля, но при этом он образует почти в три раза меньше прикорневых листьев и генеративных побегов.

Таблица 2 Оценка успешности интродукции

\begin{tabular}{|l|c|c|c|c|c|c|c|c|c|}
\hline \multicolumn{1}{|c|}{ Вид } & $\begin{array}{c}\text { Интенсив- } \\
\text { ность пло- } \\
\text { доношения }\end{array}$ & $\begin{array}{c}\text { Всхо- } \\
\text { жесть } \\
\text { семян }\end{array}$ & $\begin{array}{c}\text { Семенное } \\
\text { размноже- } \\
\text { ние }\end{array}$ & $\begin{array}{c}\text { Вегетатив- } \\
\text { ное раз- } \\
\text { множение }\end{array}$ & $\begin{array}{c}\text { Габитус } \\
\text { в куль- } \\
\text { туре }\end{array}$ & $\begin{array}{c}\text { Повреждаемость } \\
\text { болезнями } \\
\text { и вредителями }\end{array}$ & $\begin{array}{c}\text { Зимо- } \\
\text { стой- } \\
\text { кость }\end{array}$ & $\begin{array}{c}\text { Сумма } \\
\text { баллов }\end{array}$ & $\begin{array}{c}\text { Перспек- } \\
\text { тивность }\end{array}$ \\
\hline Silaum silaus & 3 & 3 & 3 & 3 & 3 & 3 & - & 21 & ОП \\
\hline Levisticum officinale & 3 & 3 & 3 & 3 & 3 & 3 & 3 & 21 & ОП \\
\hline
\end{tabular}

Примечание: ОП-очень перспективные. 
Морфологические показатели характеризуются нормальной степенью варьирования (от 1,4 до $19,7 \%$ ). Для оценки успешности интродукции нами по трехбалльной системе оценивались семь признаков растений. Балл 1 - наихудшее состояние, балл 3 - наилучшее. По суммарной оценке виды отнесены к группе очень перспективных (ОП - 18-21 баллов) и их можно рекомендовать для широкого использования в качестве пряного сырья.

Выводы. В результате интродукции морковника обыкновенного и любистока лекар- ственного нами выявлено, что в условиях Башкирского Предуралья они проходят полный цикл своего развития, ежегодно цветут, плодоносят, завязывая полноценные семена. Могут быть рекомендованы к использованию в качестве сырья в некоторых отраслях пищевой промышленности и кулинарии, а также в ликероводочном производстве.

Работа выполнена в рамках государственного задания ЮУБСИ УФИЦ РАН по теме № AAAA-A18-118011990151-7.

\section{Библиографический список}

1. Машанов, В.И. Пряно-ароматические растения [Текст] / В.И. Машанов, А.А. Покровский. М.: Агропромиздат, 1991. С. 184-187.

2. Поляков, В.А. Плодово-ягодное и растительное сырьё в производстве напитков [Текст] / В.А. Поляков, И.И. Бурачевский, А.В. Тихомиров и др. М.: ДеЛи плюс, 2011. С. 105-106.

3. Кадильникова, Е.И. Климат района г. Уфы. Записки Башкирского филиала Географического общества СССР [Текст] / Е.И. Кадильникова. Уфа, 1960. С. 61-71.

4. Бейдеман, И.Н. Методика изучения фенологии растений и растительных сообществ [Текст] / И.Н. Бейдеман. Новосибирск: Наука, 1974. $155 \mathrm{c}$.

5. Трулевич, Н.В. Эколого-фитоценотические основы интродукции растений [Текст] / Н.В. Трулевич. М.: Наука, 1991. 216 с.
6. Зайцев, Г.Н. Математика в экспериментальной ботанике [Текст] / Г.Н. Зайцев. М.: Наука, 1990. 296 с.

7. Карписонова, Р.А. Редкие виды травянистых растений широколиственных лесов СССР в Главном ботаническом саду [Текст] / Р.А. Карписонова // Бюлл. ГБС АН СССР. 1979. Вып. 112. C. $54-59$.

8. Томилова, Л.И. Эндемики флоры Урала в Ботаническом саду в Свердловске [Текст] / Л.И. Томилова // Бюлл. ГБС. 1982. Вып. 126. С. 25-31.

9. Определитель высших растений Башкирской АССР [Текст]. М.: Наука, 1989. С. 165166 .

10. Воронина, Е.П. Новые ароматические растения для Черноземья [Текст] / Е.П. Воронина, Ю.Н. Горбунов, Е.О. Горбунова. М.: Наука, 2001. С. 64-67.

\section{Сведения об авторах}

1. Анищенко Ирина Евгеньевна, кандидат биологических наук, ведущий научный сотрудник лаборатории дикорастущей флоры и интродукции травянистых растений Южно-Уральского ботанического сада-института УФИЦ РАН, 450080, Республика Башкортостан, г. Уфа, ул. Менделеева, д. 195/3, тел.: (347) 286-12-55, e-mail: irina6106@mail.ru.

2. Жигунов Олег Юрьевич, кандидат биологических наук, старший научный сотрудник лаборатории дикорастущей флоры и интродукции травянистых растений Южно-Уральского ботанического сада-института УФИЦ РАН, 450080, Республика Башкортостан, г. Уфа, ул. Менделеева, д. 195/3, тел.: (347) 286-12-55, e-mail: zhigunov2007@yandex.ru.

3. Иибирдина Лилия Маратовна, кандидат биологических наук, доцент кафедры лесоводства и ландшафтного дизайна, ФГБОУ ВО Башкирский ГАУ, 450001, Республика Башкортостан, г. Уфа, ул. 50-летия Октября, д. 34, тел.: (347) 228-68-11.

В настоящей работе представлены результаты изучения особенностей сезонного ритма роста и развития, морфометрических показателей и оценки успешности интродукции двух малоиспользуемых пряно-ароматических видов семейства Apiaceae - Silaum silaus (морковник обыкновенный) и Levisticum officinale (любисток лекарственный) в условиях культуры. Исследования проводились в Южно-Уральском ботаническом саду. Весеннее отрастание у Silaum silaus и Levisticum officinale происходит в конце апреля, в фазу бутонизации растения 
вступают во второй декаде июня, массовое цветение у любистока лекарственного начинается в первой декаде июля, у морковника обыкновенного - во второй декаде июля. Период цветения обоих видов в среднем составляет 35 дней. Созревание семян у любистока лекарственного начинается в конце августа, у морковника обыкновенного - в середине сентября. Из двух изученных видов пряно-ароматических растений любисток лекарственный отличается более высокими показателями по высоте растений и толщине стебля, но при этом он образует почти в три раза меньше прикорневых листьев и генера- тивных побегов. Морфологические показатели характеризуются нормальной степенью варьирования (от 1,4 до 19,7 \%). В результате интродукции морковника обыкновенного и любистока лекарственного нами выявлено, что в условиях Башкирского Предуралья они проходят полный цикл своего развития, ежегодно цветут, плодоносят, завязывая полноценные семена. Могут быть рекомендованы к использованию в качестве сырья в некоторых отраслях пищевой промышленности и кулинарии, а также в ликероводочном производстве.

I. Anishchenko, O. Zhigunov, L. Ishbirdina

\title{
RARELY USED AROMATIC PLANTS IN THE BASHKIR CIS-URALS
}

\begin{abstract}
Key words: aromatic plants; morphometric parameters; seasonal rhythm of development; success of introduction.
\end{abstract}

\section{Authors' personal details}

1. Anishchenko Irina, Candidate of Biological Sciences, Leading Researcher of the laboratory of wildgrowing flora and herbaceous plant introduction, South-Ural Botanical Garden-Institute of Ufa Federal Research Center of Russian Academy of Sciences, 450080, Bashkortostan, Ufa, Mendeleev St., 195/3, phone: (347) 286-12-55, e-mail: irina6106@mail.ru.

2. Zhigunov Oleg, Candidate of Biological Sciences, Senior Researcher of the laboratory of wild-growing flora and herbaceous plant introduction, South-Ural Botanical Garden-Institute of Ufa Federal Research Center of Russian Academy of Sciences, 450080, Bashkortostan, Ufa, Mendeleev St., 195/3, phone: (347) 286-12-55, e-mail: zhigunov2007@yandex.ru.

3. Ishbirdina Liliya, Candidate of Biological Sciences, Associate Professor of Forestry and Landscaping Department, Federal State Budgetary Educational Institution of Higher Education «Bashkir State Agrarian University», 450001, Bashkortostan, Ufa, 50-letiya Oktyabrya St., 34, phone: (347) 228-68-11.

Two rarely used aromatic species of the Apiaceae family - Silaum silaus and Levisticum officinale in their habitat were studied. Features of their seasonal growth and development rhythm, morphometric indicators were considered, success of the plant introduction was measured. The study was conducted in the South Ural botanical garden. Silaum silaus and Levisticum officinale both have spring aftergrowing at the end of April, budding in the second ten-day period of June; Levisticum officinale starts to blossom in the first ten-day period of July, while Silaum silaus starts to bloom in the second ten-day period of July. The blooming period of both plants averages 35 days. Seeds of Levisticum officinale begin to mature at the end of August, while seeds of Silaum silaus start ripening in the middle of September. In comparison to the second species Levisticum officinale features higher rates in height and stalk thickness, however, the plant forms three times fewer bottom leaves and generative shoots. Morphological indicators have standard variation rates (from 1,4 to $19,7 \%$ ). The introduction of Silaum silaus and Levisticum officinale revealed that in the Bashkir Cis-Urals the plants complete the development cycle, that is, blossom, give yield, set full seeds. The study plants can be recommended for use as raw materials in food production, cooking and alcoholic beverage production.

(c) Анищенко И.Е, Жигунов О.Ю., Ишбирдина Л.М. 
УДК 634.445

DOI: $10.31563 / 1684-7628-2019-51-3-10-13$

Н.Н. Зайцева, Н.А. Фадеева, О.А. Васильев

\title{
ЭФФЕКТИВНОСТЬ ПРИМЕНЕНИЯ ТВЕРДЫХ ПРОДУКТОВ БИОГАЗОВОЙ УСТАНОВКИ НА НЕФТЕЗАГРЯЗНЕННЫХ ПОЧВАХ
}

\author{
Ключевые слова: биологическое удобрение; нефтезагрязненные почвы; нефтепродукты; про- \\ дукты биогазовой установки; химический состав; ячмень.
}

Введение. Химическое загрязнение земель это изменение их химического состава в результате антропогенной деятельности, способное вызвать ухудшение качества земель, что в конечном счете отрицательно влияет на продуктивность почв и здоровье проживающих на территории людей. От загрязнений нефтью и ее продуктами в первую очередь страдает почва: уменьшается поровое пространство, понижаются значения окислительно-восстановительного потенциала, угнетается активность аэробных микроорганизмов, что приводит к снижению плодородия. Восстановление химически загрязненных земель - дорогостоящее мероприятие, поэтому поиск эффективных и менее затратных приемов носит актуальный характер.

Исследования по использованию твердых продуктов биогазовой установки (биоудобрений) на основе птичьего помета, присланного из ООО «НПО «Агробиогаз» г. Санкт-Петербург, проводились на опытном участке ФГБОУ ВО «Чувашская государственная сельскохозяйственная академия». На опытном участке верхний гумусовый горизонт был удален в связи с реконструкцией и планировкой территории, поэтому почвенный покров его представлен «скальпированной» светло-серой лесной тяжелосуглинистой почвой на элювии пермских глин с выходящим на дневную поверхность подпахотным горизонтом $\mathrm{A}_{2} \mathrm{~B}$.

Действие биогазовой установки основано на анаэробном сбраживании органических веществ (птичьего помета, навоза, гнилого картофеля, отходов переработки зерна и др.), в результате чего образуется биогаз, а также жидкие и твердые продукты, имеющие переменный химический состав и пригодные для применения в качестве удобрений сельскохозяйственных культур. Жидкие продукты биогазовой установки исследовались в качестве удобрения сельскохозяйственных культур в 2014-2016 гг. и показали положительное воздействие на их продуктивность $[1,2,8]$.

В последние годы в Российской Федерации широкое развитие получила птицеводческая промышленность, а именно - производство куриного мяса и яиц. При этом ежедневно образуются тысячи тонн куриного навоза, который не всегда перерабатывается на удобрение. В свежем курином помёте содержится 50-60 \% воды, 1,6-2,0 \% азота, 1,3-2,5 \% фосфора, 0,8-1,0\% калия, 2,-3,0 \% кальция, 0,5-0,9 \% магния, 0,30,7 \% серы, 39,0-45,0 \% - органическое вещество. Однако в свежем виде куриный навоз в больших дозах токсичен для культурных растений, а хранение его в пределах птицефабрики сокращает производственные площади и загрязняет окружающую воздушную среду. Поэтому одним из вариантов утилизации свежего куриного навоза является его переработка. Куриный помет, преобразуясь в биогазовой установке с выделением используемых в хозяйственных целях горючей смеси газов для отопления помещений и жидких продуктов в качестве удобрения, выпадая на дне биореактора в твердый осадок, сохраняет питательную ценность для сельскохозяйственных культур. Однако эффективность твердых продуктов биогазовой установки в качестве удобрений сельскохозяйственных культур слабо изучена.

Цель исследований - изучить возможность восстановления плодородия нефтезагрязненных почв с помощью применения твердых продуктов биогазовой установки.

Условия и методы исследований. Опыт закладывался летом 2017 г. в пятикратной повторности на делянках площадью $1 \mathrm{~m}^{2}$. Сначала на делянках удалялся верхний слой почвы и поверхность выравнивалась строго горизонтально, чтобы нефтепродукты не концентрировались в понижениях, а распределялись равномерно по всей площади. После этого вносилось загрязняющее вещество (масло-отработка в дозе 3 л/м²). Далее поверхность опытных делянок покрывалась слоем удаленной почвы 5 см, который уплотнялся, и сверху насыпался песок слоем $10 \mathrm{~cm}$, перемешанный с разными дозами твердого биоудобрения из расчета 30, 60 и 90 т/га. Так на делянке имитировались предполагаемые операции рекультивации нефтезагрязненных зе- 
мель. Агрохимические показатели почв делянок определяли в вытяжке по Кирсанову; содержание гумуса - методом Тюрина. На делянки высевался ячмень сорта Памяти Чепелева. На каждой делянке было посеяно одинаковое количество семян ячменя (по 500 штук на каждую делянку). Контролем служил вариант, загрязненный нефтепродуктами и покрытый песком без внесения биоудобрения. Еженедельно фиксировалось развитие растений ячменя.

Результаты исследований. Птичий помет, служащий основным сырьем для переработки в биогазовой установке, богат азотом, фосфором, калием, кальцием, магнием и другими элементами питания растений. Анаэробное брожение в биогазовой установке понижает содержание азота в твердых продуктах, так как он частично переходит в состав горючего газа. Фосфор, калий, кальций, марганец и другие катионы металлов, включая микроэлементы, в основном остаются в твердых продуктах. Таким образом, с твердыми отходами биогазовой установки, используемыми в качестве удобрения, одновременно с нормой азота вносятся и другие элементы питания растений, восполняющие вынос их из почвы с урожаем, а также и микроорганизмы, повышающие биологическую активность почвы, активаторы роста и развития растений - ауксины, гумусовые вещества и др. [2, $5]$.

При внесении их в почву в качестве удобрения сельскохозяйственных культур в пахотном слое увеличиваются биологическая активность, содержание подвижных форм макро- и микроэлементов и др. питательных веществ, что в итоге повышает эффективность производства продукции растениеводства $[3,4]$.

Извлеченные из биореактора твердые продукты некоторое время хранятся на площадке до достижения влажности 55-62 \%. Готовые твердые продукты биогазовой установки (ПТБУ) представляют собой темно-серую или черную торфоподобную рыхлую массу с влажностью 50-60 \% со слабым болотным запахом. Содер- жание макроэлементов в сухом веществе биоудобрения несколько выше (в 4-10 раза), чем в полуперепревшем навозе КРС, и сравнимо с химическим составом осадков городских сточных вод [5]. Одна тонна натурального вещества ТБУ содержит в среднем 16,5 кг/т общего азота, 20 кг/т общего фосфора и около 16 кг/т общего калия, большое количество микроэлементов. Пестицидов обнаружено не было. Отличие твердых отходов биогазовой установки от исходного материала - свежего птичьего помета - проявляется в том, что они рыхлые, рассыпчатые и равномернее вносятся в почву, не обжигая растения.

Всходы ячменя были равномерными на всех делянках. В дальнейшем по мере развития растений ячменя и достижения их корневыми системами загрязненного нефтепродуктами слоя растения в контрольном варианте, также искусственно загрязненного нефтепродуктами (без применения ТБУ), начали угнетаться в развитии. В меньшей степени угнетение в развитии, выражающееся в отставании в росте, желтизне на кончиках листьев, проявилась во втором варианте (доза 30 т/га биоудобрения) и практически не было заметно в делянках с внесением ПТБУ в дозах из расчета 60 и 90 т/га.

В вариантах с внесением ПТБУ в дозах 60 и 90 т/га растения ячменя не испытывали дефицита азота: листья имели насыщенный зеленый цвет. Кущение ячменя также лучше на участках с максимальными дозами внесения биоудобрения. Применение биоудобрения положительно отразилось на урожайности ячменя - она показана в таблице 1 .

Таким образом, применение ПТБУ на загрязненных почвах ослабляет токсическое действие нефтепродуктов и с увеличением дозы последовательно повышает урожайность ячменя с 0,50 (контроль) до 1,29 (60 т/га) и до 2,67 т/га (90 т/га). Почвенные пробы с делянок отбирались после уборки ячменя. Агрохимические показатели почвы в слое 0-15 см в вариантах опыта показаны в таблице 2 .

Таблица 1 Урожайность ячменя на искусственно загрязненных нефтепродуктами почвах

\begin{tabular}{|c|c|c|c|c|c|}
\hline № п.п. & Вариант & $\begin{array}{c}\text { Среднее количество растений } \\
\text { на делянке, шт. }\end{array}$ & 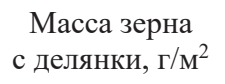 & Урожайность,т/га & Прибавка, т/га \\
\hline 1 & Контроль & 94 & 49,8 & 0,50 & - \\
\hline 2 & ПТБУ 30 т/га & 136 & 76,1 & 0,76 & 0,26 \\
\hline 3 & ПТБУ 60 т/га & 219 & 129,2 & 1,29 & 0,79 \\
\hline 4 & ПТБУ 90 т/га & 292 & 267,1 & 2,67 & 2,17 \\
\hline- & $\mathrm{HCP}_{05}$ & - & - & 0,18 & - \\
\hline
\end{tabular}


Таблица 2 Агрохимическая характеристика подвижной формы элементов питания растений в слое $0-15$ см на 27.10.17 г.

\begin{tabular}{|c|c|c|c|c|c|c|}
\hline № п.п. & Вариант & Гумус, $\%$ & К $_{2} \mathrm{O}$, мг/кг & СаО, мг/кг & $\mathrm{Na}_{2} \mathrm{O}$, мг/кг & $\mathrm{P}_{2} \mathrm{O}_{5}$, мг/кг \\
\hline 1 & Контроль & 0,14 & 67,5 & 105 & 40,0 & 57 \\
\hline 2 & ПТБУ 30т/га & 1,18 & 202,9 & 310 & 120,0 & 262,3 \\
\hline 3 & ПТБУ 60 т/га & 1,35 & 435,3 & 390 & 160,0 & 378,6 \\
\hline 4 & ПТБУ 90 т/га & 1,82 & 485,3 & 400 & 215,0 & 490,2 \\
\hline
\end{tabular}

Из данных таблицы 2 следует, что применение ПТБУ вызывает увеличение содержания гумуса и подвижных элементов питания растений в пахотном слое почвы $[3,4,6,7]$. Таким образом, в результате проведенных научных исследований в течение вегетационного периода 2017 г. выявлено, что биоудобрения в дозах 60 и 90 т/га снижают токсичность загрязненных почв нефтепродуктами и повышают урожайность ячменя.
Заключение. Применение ПТБУ в условиях вегетационного периода 2017 г. на искусственно загрязненных нефтепродуктами почвах повысило урожайность ячменя с 0,50 (контроль) до 1,29 (60 т/га) и до 2,67 т/га (90 т/га). Результаты проведенных научных исследований показали, что твердые продукты биогазовой установки могут эффективно применяться в качестве мелиоранта на загрязненных нефтепродуктами почваx.

\section{Библиографический список}

1. Васильев, О.А. Эффективность использования отходов биогазовой установки в качестве некорневой подкормки яровой пшеницы на серых лесных почвах Чувашии [Текст] / О.А. Васильев, Н.Н. Зайцева, Д.П. Кирьянов // Вестник Башкирского государственного аграрного университета. 2016. № 4 (40). С. 7-12.

2. Васильев, О.А. Влияние некорневой подкормки микроэлементами на урожайность и качество зерна яровой пшеницы на серых лесных почвах Чувашии [Текст] / О.А. Васильев, А.Н. Смирнова // Вестник Башкирского государственного аграрного университета. 2015. № 1 (33). C. 11-16.

3. Иванова, Т.Н. Динамика агрохимических показателей плодородия почвы по результатам локального мониторинга [Текст] / Т.Н. Иванова, В.С. Сергеев // Вестник Башкирского аграрного университета. 2017. № 2 (42). C. 11-15.

4. Ильина, Т.А. Экологическое состояние агроландшафтов и особо охраняемых природных территорий Чувашской Республики [Текст]: монография / Т.А. Ильина, О.А. Васильев. Чебоксары: Новое время, 2011. С. 153.
5. Кириллов, Н.К. Действие осадков сточных вод г. Чебоксары на урожайность и качество сельскохозяйственной продукции [Текст] / Н.К. Кириллов, Л.Н. Михайлов, Н.А. Кириллов, О.А. Васильев, Н.А. Фадеева // Вестник Саратовского госагроуниверситета им. Н.И. Вавилова. 2006. № 1. С. 23-27.

6. Ложкин, А.Г. Мониторинг физического состояния серых лесных почв при сельскохозяйственном использовании [Текст] / А.Г. Ложкин, А.В. Чернов, В.Г. Егоров // Землеустройство, кадастр и мониторинг земель. 2018. № 5 (160). C. 57-62.

7. Чернов, А. В. Динамика плодородия почв Чувашской Республики [Текст] / А.В. Чернов, О.А. Васильев // Агроэкологические и организационно-экономические аспекты создания и эффективного функционирования экологически стабильных территорий. Материалы Всероссийской научно-практической конференции. 5 октября 2017 г. Чебоксары: ЧГСХА, 2017. С. 157 163.

8. Чернов, А.В. Влияние ЭМ-технологии на плодородие серых лесных почв [Текст] / А.В. Чернов, О.П. Нестерова // Землеустройство, кадастр и мониторинг земель. 2017. № 4.

\section{Сведения об авторах}

1. Зайцева Наталья Николаевна, соискатель, генеральный директор ООО «Аталану» Канашского района Чувашской Республики, 428003, Чувашская Республика, г. Чебоксары, ул. К. Маркса, 29, e-mail: atalanu@mail.ru. 
2. Фадеева Наталья Анатольевна, кандидат сельскохозяйственных наук, доцент кафедры земледелия, растениеводства, селекции и семеноводства, ФГБОУ ВО Чувашская ГСХА, 428003, Чувашская Республика, г. Чебоксары, ул. К. Маркса, 29, e-mail: nfadeeva1@yandex.ru.

3. Васильев Олег Александрович, доктор биологических наук, профессор кафедры землеустройства и кадастров, ФГБОУ ВО «Чувашская государственная сельскохозяйственная академия», 428003, Чувашская Республика, г. Чебоксары, ул. К. Маркса, 29, тел.: (8352) 62-06-19.

Статья содержит результаты научных исследований по применению твердых продуктов переработки птичьего помета в биогазовой установке $\mathrm{OOO}$ «НПО «Агробиогаз» г. Санкт Петербург (далее - ТБУ или твердое биоудобрение) на почвах, загрязненных нефтепродуктами. Твердые продукты переработки биогазовой установки относятся к нетрадиционному виду органических удобрений. Определен химический состав биоудобрения: в 1 тонне натурального вещества содержатся в среднем 16,5 кг/т общего азота, 20 кг/т общего фосфора и около 16 кг/т об- щего калия, а также микроэлементы. Проведенные научные исследования выявили, что применение биоудобрения на искусственно загрязненных нефтепродуктами почвах ослабляет их токсическое действие и с увеличением дозы внесения биоудобрений последовательно повышает урожайность ячменя. Результаты научных исследований показали, что твердые продукты биогазовой установки могут эффективно применяться в качестве мелиоранта на загрязненных нефтепродуктами почвах.

N. Zaytseva, N. Fadeeva, O. Vasilyev

EFFICIENCY OF APPLICATION

OF SOLID PRODUCTS OF BIOGAS INSTALLATION

ON OIL-POLLUTED SOILS

Key words: biological fertilizer; oil contaminated soils; oil products; biogas plant products; chemical composition; barley.

\section{Authors' personal details}

1. Zaytseva Natalya, applicant, general director of Atalanu LLC, Kanashsky district of the Chuvash Republic, 428003, the Chuvash Republic, Cheboksary, K. Marx, 29, e-mail: atalanu@mail.ru.

2. Fadeeva Natalya, Candidate of Agricultural Sciences, Associate Professor of the Department of Agriculture, Plant Growing, Breeding and Seed Production, Chuvash State Agricultural Academy, 428003, Chuvash Republic, Cheboksary, K. Marx, 29, e-mail: nfadeeva1@yandex.ru.

3. Vasilyev Oleg, Doctor of Biological Sciences, Professor of the Department of Land Management and Cadastres, Chuvash State Agricultural Academy, 428003, the Chuvash Republic, Cheboksary, K. Marx, 29, phone: (8352) 62-06-19.

The article contains the results of scientific research on the use of solid products from the processing of poultry manure in a biogas plant of $\mathrm{OOO}$ NPO Agrobiogaz, St. Petersburg (hereinafter referred to as TBU or solid bio-fertilizer) on soils contaminated with oil products. Solid biogas plant processing products are a non-traditional type of organic fertilizer. The chemical composition of biofertilizer was determined: 1 ton of a natural substance contains on average $16,5 \mathrm{~kg} /$ ton of total ni- trogen, $20 \mathrm{~kg} /$ ton of total phosphorus and about $16 \mathrm{~kg} /$ ton of total potassium, as well as trace elements. Scientific studies have shown that the use of bio-fertilizer on artificially polluted soils weakens their toxic effect, and with an increase in the dose of bio-fertilizers, it consistently increases the yield of barley. The results of scientific studies have shown that solid products of a biogas plant can be effectively used as improver on oil-polluted soils.

(C) Зайцева Н.Н., Фадеева Н.А., Васильев О.А. 
УДК $630 * 261$

DOI: $10.31563 / 1684-7628-2019-51-3-14-19$

И.Г. Сабирзянов, К.М. Габдрахимов, Л.Н. Блонская

\section{ДЕПОНИРОВАНИЕ УГЛЕРОДА РАСТЕНИЯМИ В РЕСПУБЛИКЕ БАШКОРТОСТАН}

\section{Ключевые слова: парниковые газы; депонирование углерода; зелёные растения; нетто-погло- щение; бюджет углерода.}

Введение. Парниковые газы всегда присутствуют в атмосфере и благодаря им на земле поддерживается определённая температура воздуха, при которой зарождаются и поддерживаются различные формы жизни на нашей планете [19]. За последние столетия концентрация углекислоты в атмосфере повысилась на $20 \%$, и это не сопровождается увеличением запасов фитомассы растительного покрова. При этом площадь мировых лесов в результате рубок и пожаров ежегодно сокращается [14]. В связи с этим не исключена возможность возникновения на планете так называемого «парникового эффекта», что может привести к глобальному изменению климата [2]. Согласно докладу о кадастре антропогенных выбросов из источников и абсорбции поглотителями парниковых газов, нерегулируемых Монреальским протоколом за 1990-2016 гг. (таблица 1), доминирующая роль по атмосферным выбросам в России принадлежит сектору энергетики. Выбросы, которые связаны с отходами, также показывают постоянный рост. Вклад сельского хозяйства в связи с сокращением пахотных площадей и увеличением урожайности культур по выбросам в атмосферу парниковых газов за последнее десятилетие уменьшился [10].

Экологические проблемы не могут быть решены без участия лесов. Ведение лесного хозяйства должно быть ориентировано на охрану, преобразование и восстановление лесов на наиболее высокой ступени - на создание лесов повышенной экологической продуктивности. Экологическая продуктивность тесно взаимосвязана с биологической. Обычно чем больше биологическая продуктивность, тем выше и экологическая [2]. В связи со сложившейся проблемой по выбросам в атмосферу огромного объёма углекислого газа, метана и других парниковых газов лесные экосистемы стали рассматривать в новом аспекте. Ежегодные суммарные объёмы углерода, поглощаемые лесами Российской Федерации, составляют 261,64 млн т, что является эквивалентом 959 млн т углекислого газа [7]. По состоянию на 1 января 2018 г. площадь земельного фонда в Республике Башкортостан составляет 14294,7 тыс. га, из которых на земли сельскохозяйственного назначения приходится 7279,4 тыс. га (50,9 \%), земли промышленности, транспорта и иного назначения - 116,3 тыс. га $(0,8 \%)$, на долю земель лесного фонда приходится 5721,5 тыс. га $(40,0 \%)$ земель. Около 6624,7 тыс. га (91,0 \%) площади земель сельскохозяйственного назначения приходится на долю сельскохозяйственных угодий, где доля пашен составляет 3458 тыс. га. Леса, не входящие в лесной фонд, распределены на площади 316,2 тыс. га (4,4 \%) [3]. Леса, депонируя углерод, являются поглотителями парниковых газов, что хотя бы отчасти балансирует мощные выбросы в атмосферу углекислого газа, образуемые при сжигании природного топлива.

Таблица 1 Распределение выбросов парниковых газов по секторам, \%

\begin{tabular}{|c|c|c|c|c|c|}
\hline \multirow{2}{*}{ Год } & \multicolumn{5}{|c|}{ Сектор } \\
\cline { 2 - 6 } & энергетика & промышленность & сельское хозяйство & отходы & всего \\
\hline 2017 & 82,3 & 8,2 & 5,1 & 4,4 & 100 \\
\hline 1990 & 81,5 & 7,6 & 8,7 & 2,2 & 100 \\
\hline
\end{tabular}

Цель исследований: изучение депонирования углерода (C) на территории Республики Башкортостан.

Задачи исследований: рассчитать и провести сравнительный анализ бюджета углерода на территории земель лесного фонда в Республике
Башкортостан по состоянию на 2007 и 2017 годы; изучить показатели по нетто-поглощению углерода хвойными древесными растениями в зависимости от группы возраста; рассчитать объём депонированного углерода и определить факторы зависимости этих изменений. 
Условия, материалы и методы исследования. Материалами для исследований явились данные государственного лесного реестра. Депонирование углерода хвойными насаждениями рассчитано по методике, утверждённой распоряжением Минприроды от 30.06.2017 г. № 20-р «Об утверждении методических указаний по количественному определению объёма поглощения парниковых газов». Научная новизна: проведён расчёт депонирования углерода растениями по новой методике [1].

Результаты исследования. Агроэкосистемы очень разнообразны в зависимости от выращиваемых культур, севооборотов, от состава и плодородия почв, а также от состояния последних, определяемого степенью эрозии, заболоченности, засоления и т. д. и даже от формы собственности на землю. При этом пулами системы являются пул фитомассы урожая, пул сорняков, послеуборочных остатков (солома, стерня, ботва, корни), привноса органических удобрений, пул почвенного гумуса после выноса углерода с урожаем. В последнее время площади земель сельхозназначения постепенно сокращаются, брошенные пашни зарастают деревьями и кустарниками. При этом сокращаются площади посевов зерновых и кормовых культур, что приводит к уменьшению запасов углерода на сельхозугодиях $[5,15-18]$. Леса в
Республике Башкортостан представлены в основном семнадцатью лесообразующими видами древесной растительности. Общая площадь основных лесообразующих пород - 5162752 га. Преобладающими из них являются насаждения берёзы, на долю которых приходится около $27 \%$ лесопокрытой площади. Второе место по площади занимают насаждения липы - $22 \%$, далее идут сосняки - $15 \%$, осинники - $14 \%$, ельники $-5 \%$. В целом на долю хвойных насаждений приходится более 20 \% площади занятых лесными насаждениями земель. Для оценки динамики экологического потенциала лесов в Республике Башкортостан, по материалам государственного лесного реестра (ГЛР), были рассчитаны показатели поглощения, потерь и бюджет углерода за 2007 и 2017 гг. (таблица 2). Согласно расчётам, по данным ГЛР 2017 года, леса ежегодно депонируют 3618,9 тыс. т С в год, в том числе биомасса древостоя 2763 тыс. т С в год [11]. На долю мёртвой древесины приходится 468 тыс. т С в год, подстилки - 87,9 тыс. т С в год, почвы - 300,2 тыс. т С в год. При этом ежегодные потери углерода деструктивными лесными пожарами, сплошными рубками, воздействием вредителей и болезнями составляют 755,2 тыс. т С в год. Бюджет углерода - разница между нетто-поглощением и потерей углерода равен 3124,4 тыс. т С в год [9].

Таблица 2 Оценка экологического потенциала лесов в РБ

\begin{tabular}{|c|c|c|c|}
\hline \multirow{2}{*}{ Функция } & \multirow{2}{*}{ Показатель } & \multicolumn{2}{|c|}{ Тыс. т С в год } \\
\hline & & за 2007 год & за 2017 год \\
\hline \multirow{5}{*}{ Нетто-поглощение } & Биомасса древостоя & 3032,2 & 2763 \\
\hline & Мёртвая древесина & 506,8 & 468 \\
\hline & Подстилка & 82,5 & 87,9 \\
\hline & Почва & 281,3 & 300,2 \\
\hline & Итого по всем пулам & 3902,7 & 3618,9 \\
\hline \multirow{4}{*}{$\begin{array}{c}\text { Потеря углерода } \\
\text { управляемыми лесами }\end{array}$} & Деструктивные лесные пожары & $-20,9$ & $-18,9$ \\
\hline & Вредители и болезни & $-5,11$ & $-15,6$ \\
\hline & Сплошные рубки & $-511,49$ & $-720,7$ \\
\hline & Всего потери & $-537,5$ & $-755,2$ \\
\hline \multirow{5}{*}{$\begin{array}{c}\text { Бюджет углерода } \\
\text { по пулам }\end{array}$} & Биомасса древостоя & 2639 & 2475,2 \\
\hline & Мёртвая древесина & 427,3 & 354 \\
\hline & Подстилка & 68,8 & 68,3 \\
\hline & Почва & 230,1 & 227 \\
\hline & Итого по всем пулам & 3365,2 & 3124,4 \\
\hline
\end{tabular}

При этом показатели нетто-поглощения углерода по сравнению с 2007 годом имеют тенденцию к уменьшению. Это связано с некоторым увеличением доли перестойных древесных насаждений мягколиственных пород. Потери уг- лерода управляемыми лесами в 2017 году имеют тенденцию к увеличению от 537,5 до 755,2 тыс. т С в год. Увеличение потерь углерода связано с изменением площадей заражённых лесных участков болезнями, вредителями и увеличе- 
нием площадей сплошных рубок. Всё это в целом повлияло на некоторое снижение бюджета углерода. Объём поглощения углерода лесами зависит от интенсивности лесохозяйственной деятельности. Изменение объёмов лесозаготовок приводит к существенному изменению стока углерода [4]. Разные лесные древесные породы по-разному влияют на стоки углерода. Это зависит от биологических особенностей растений, в том числе от наземной биомассы и ежегодного прироста. Российские леса ежегодно накапливают 34 млрд т C, среди них на долю хвойных лесных древесных растений приходится более 25 млрд т С [13]. Нами проведён анализ нетто-поглощения углерода различными лесными древесными породами, входящими в класс хвойные, которые в лесах Республики Башкортостан представлены сосной, елью, пихтой, лиственницей и кедром. Для определения нетто-поглощения углерода хвойными лесообразующими насаждениями были проведены расчёты запаса углерода в биомассе древостоев хвойных пород. При этом больше всего накоплено углерода в сосняках, что составляет 51668,86 тыс. т С (таблица 3). На втором месте еловые насаждения с запасом углерода 13074,07 тыс. т С. Замыкают ряд площади лиственничных, пихтовых и кедровых древостоев. При изучении распределения запасов углерода в биомассе насаждений в зависимости от группы возраста в сосняках выявлено, что больше всего углерода накоплено в молодняках - 33,35 \% от общего запаса, в средневозрастных их объём составляет $21,90 \%$, в приспевающих - 13,89 \%, в спелых насаждениях - 30,86 \%.

При определении средних запасов углерода биомассы насаждений были получены данные, при которых больше всего углерода в биомассе насаждений у сосняков в средневозрастных древостоях - 79,62 т С/га, немного меньше в приспевающих насаждениях - 76,66 т С/га, в спелых - 77,3 т С/га, в молодняках - 49,34 т С/га. Конверсионные коэффициенты для расчёта запаса углерода в биомассе древостоя по объёмному запасу для зоны, в которой располагается Республика Башкортостан, в зависимости от группы возраста насаждений распределяются так, что в молодняках для сосняков он равен 0,435 т С/ куб. м, для средневозрастных насаждений 0,352 т C/ куб. м, приспевающих - 0,329 т C/ куб. м, для спелых - 0,356 т С/ куб. м. Значения средних углеродных запасов в биомассе древесной растительности зависят от запасов насаждений и от группы возраста. В связи с этим, несмотря на то, что каждый кубический метр биомассы молодняков накапливает до 0,435 т С/ куб. м, из-за небольшого их запаса на единице площади среднее содержание углерода в биомассе минимальное. Больше всего накапливается углерода в приспевающих и средневозрастных группах сосновых насаждений. Относительно большие запасы углерода в биомассе насаждений молодняков - это результат больших площадей, созданных в последние годы лесных культур хвойных видов. По еловым насаждениям получены аналогичные данные: в молодняках накоплено 52 \% углерода, в средневозрастных - 11,73 \%, приспевающих - 12,35 \%, спелых и перестойных - 23,92 \% углерода соответственно. Чем моложе насаждения, тем они лучше выполняют свои экологические функции, то есть имеют больше возможности для накопления углерода в биомассе [12].

При исследовании накопления углерода биомассой другими насаждениями мы получили данные, которые примерно схожи с результатами исследований по соснякам.

По распределению площади (таблица 4) покрытой лесной растительностью земель на долю хвойных молодняков приходится 48,71 \% земель, средневозрастные насаждения занимают 15,28 \%, приспевающие - 11,46 \%, спелые, перестойные - 24,55 \%. По запасу углерода в биомассе древостоев больше всего их в молодняках, что связано высокими конверсионными коэффициентами и их большими площадями.

Таблица 3 Распределение запаса углерода в биомассе насаждений

\begin{tabular}{|c|c|c|c|c|c|c|}
\hline \multirow[t]{2}{*}{ Группа возраста } & \multicolumn{6}{|c|}{$\begin{array}{c}\text { Запас углерода в биомассе древостоев, тыс. т C / } \\
\text { средний запас углерода биомассы насаждений, т C/ га }\end{array}$} \\
\hline & ель & пихта & сосна & лиственница & кедр & итого \\
\hline Молодняки & $\begin{array}{c}6864,21 / \\
36,78\end{array}$ & $\begin{array}{c}237,13 / \\
26,41\end{array}$ & $\begin{array}{c}17230 / \\
49,34 \\
\end{array}$ & $\begin{array}{c}431,83 / \\
33,92 \\
\end{array}$ & $\begin{array}{l}8,71 / \\
46,79 \\
\end{array}$ & $\begin{array}{c}24771,9 / \\
146,45\end{array}$ \\
\hline Средневозрастные & $\begin{array}{c}1533,78 / \\
73,61 \\
\end{array}$ & $\begin{array}{c}560,71 / \\
54,86\end{array}$ & $\begin{array}{c}10797,07 / \\
79,62\end{array}$ & $\begin{array}{c}644,87 / \\
78,02 \\
\end{array}$ & $\begin{array}{c}0,14 / \\
136 \\
\end{array}$ & $\begin{array}{c}13536,57 / \\
422,11 \\
\end{array}$ \\
\hline Приспевающие & $\begin{array}{c}1615,02 / \\
77,26\end{array}$ & $\begin{array}{c}629,56 / \\
62,96\end{array}$ & $\begin{array}{c}7176,08 / \\
76,66\end{array}$ & $\begin{array}{c}564,24 / \\
83,23 \\
\end{array}$ & 0 & $\begin{array}{c}9984,90 / \\
300,11 \\
\end{array}$ \\
\hline Спелые, перестойные & $\begin{array}{c}3061,06 / \\
76,76\end{array}$ & $\begin{array}{c}740,23 / \\
51,18\end{array}$ & $\begin{array}{c}16465,712 / \\
77,3\end{array}$ & $\begin{array}{c}1235,67 / \\
68,53\end{array}$ & 0 & $\begin{array}{c}21502,67 / \\
273,37\end{array}$ \\
\hline Всего & $\begin{array}{c}13074,07 / \\
264,41\end{array}$ & $\begin{array}{c}2167,63 / \\
195,41\end{array}$ & $\begin{array}{c}51668,86 / \\
282,92\end{array}$ & $\begin{array}{c}2876,61 / \\
263,7\end{array}$ & $\begin{array}{c}8,85 / \\
182,79\end{array}$ & $\begin{array}{c}69796 / \\
1142,44\end{array}$ \\
\hline
\end{tabular}


Далее идут спелые, перестойные насаждения, где большое накопление углерода связано с большими запасами древесины. При изучении распределения средних запасов углерода в биомассе по группам возраста в молодняках, средневозрастных, приспевающих насаждениях идёт прирост, а в спелых - небольшое уменьшение, что связано с уменьшением среднего запаса насаждений. При исследовании годичной абсорбции углерода пулом биомассы насаждений по группам возраста (таблица 5) получены результаты, по которым наилучшие показатели в средневозрастных насаждениях всех рассматриваемых видов. В этой группе возраста наблюдается наибольший прирост запаса насаждений, что соответственно напрямую влияет на депонирование углерода биомассой древесной растительности. В других группах возраста депонирование углерода у всех изучаемых видов незначительное.

Таблица 4 Распределение площади покрытой лесной растительностью земель по группам возраста, га

\begin{tabular}{|c|c|c|c|c|c|c|}
\hline \multirow{2}{*}{ Группа возраста } & \multicolumn{5}{|c|}{ Преобладающая порода } & \multirow{2}{*}{ Итого хвойных } \\
\hline & сосна & ель & лиственница & пихта & кедр & \\
\hline Молодняки 1 класса & 162802 & 128068 & 3990 & 6173 & 116 & 301149 \\
\hline Молодняки 2 класса & 186426 & 58550 & 4990 & 6557 & 70 & 256593 \\
\hline Средневозрастные & 135599 & 20836 & 10221 & 8265 & 11 & 174922 \\
\hline Приспевающие & 93604 & 20903 & 10000 & 6779 & - & 131286 \\
\hline Спелые & 203180 & 34684 & 13497 & 11866 & - & 262262 \\
\hline Перестойные & 93604 & 5196 & 965 & 6165 & - & 18816 \\
\hline Всего & 875215 & 268237 & 43663 & 45805 & 197 & 1145028 \\
\hline
\end{tabular}

Таблица 5 Годичная абсорбция углерода пулом биомассы насаждений по группам возраста, т С/ год

\begin{tabular}{|l|c|c|c|c|c|c|}
\hline \multirow{2}{*}{\multicolumn{1}{|c}{ Группа возраста }} & \multicolumn{5}{|c|}{ Годичная абсорбция углерода пулом биомассы насаждений, т С /год } \\
\cline { 2 - 7 } & сосна & ель & лиственница & пихта & кедр & итого хвойных \\
\hline Молодняки & 556890,17 & 276699,44 & 17185,50 & 10186,66 & 191,74 & 861153,5 \\
\hline Средневозрастные & 88790,22 & 16695,04 & 5206,95 & 6848,07 & 0,44 & 117540,7 \\
\hline Приспевающие & 1684,87 & 1796,61 & 565,00 & 2000,00 & 0,00 & 6046,48 \\
\hline Спелые, перестойные & 3912,14 & 199,40 & 2372,20 & 1094,61 & 0,00 & 7578,35 \\
\hline Всего & 651277,40 & 295390,5 & 25329,65 & 20129,34 & 192,18 & 992319,1 \\
\hline
\end{tabular}

Ежегодное депонирование углерода биомассой хвойных древесных растений составляет 9923,319 тыс. т С/год, что составляет $35,9 \%$ от общей массы депонированного углерода биомассой всех древесных растений.

Значимость лесов в регуляции содержания парниковых газов атмосферы была признана ключевыми международными соглашениями по сохранению глобального климата: Рамочной конвенцией ООН об изменении климата (РКИК $\mathrm{OOH})$ и Киотским протоколом $[8,11]$. Одним из важных мероприятий по снижению парникового эффекта является создание искусственных насаждений на нелесных территориях и на лесных землях, на которых, в силу ряда обстоятельств, естественного лесовосстановления не происходит. Вновь созданные лесные культуры активно вовлекаются в процессы связывания углекислого газа и повышения биологической продуктивности лесных экосистем [6].
Выводы. Бюджет углерода в лесах в Республике Башкортостан за последнее десятилетие имеет тенденцию к уменьшению, причинами чего являются накопление площадей перестойных мягколиственных насаждений, увеличение количества лесных пожаров, площади заражённых вредителями и болезнями лесов и увеличение интенсивности рубок. Наилучшие показатели по нетто-поглощению углерода имеют молодняки и средневозрастные лесные насаждения хвойной древесной растительности. Объём депонированного углерода лесными древесными растениями зависит от их биологических особенностей, возраста и изменения запаса. Хвойные древесные виды, занимая немногим более одной пятой лесных площадей, занятых лесообразующими породами, депонируют одну третью часть от общей массы депонированного биомассой углерода. 


\section{Библиографический список}

1. Об утверждении методических указаний по количественному определению объёма поглощения парниковых газов [Текст]: распоряжение Минприроды от 30.06.2017 г. № 20-р.

2. Габдрахимов, К.М. Воспроизводство и повышение экологической продуктивности лесов Южного Урала [Текст]: монография / К.М. Габдрахимов, И.Г. Сабирзянов. М.: МГУЛ, 2006. $310 \mathrm{c}$.

3. Государственный (национальный) доклад о состоянии и использовании земель в Республике Башкортостан в 2017 году [Текст]. Уфа. $244 \mathrm{c}$.

4. Замолодчиков, Д.Г. Динамика бюджета углерода лесов России за два последних десятилетия [Текст] / Д.Г. Замолодчиков, В.И. Грабовский, Г.Н. Краев // Лесоведение. 2011. № 6. C. 16-28.

5. Замолодчиков, Д.Г. УГлерод в лесном фонде и сельскохозяйственных угодьях России [Текст] / Д.Г. Замолодчиков, Г.Н. Коровин, А.И. Уткин, О.В. Честных, Б. Сонген. М.: Товарищество научных изданий КМК, 2005. 200 с.

6. Замолодчиков, Д.Г. Системы оценки и прогноза запасов углерода в лесных экосистемax [Текст] / Д.Г. Замолодчиков // Устойчивое лесопользование. 2011. № 4 (29). С. 15-22.

7. Исаев, А.С. Экологические проблемы поглощения углекислого газа посредством лесовосстановления и лесоразведения в России (аналитический обзор) [Текст] / А.С. Исаев, Г.Н. Коровин, В.И. Сухих, С.П. Титов, А.И. Уткин, А.А. Голуб, Д.Г. Замолодчиков, А.А. Пряжников. М.: Центр экологической политики, 1995. $156 \mathrm{c}$.

8. Киотский протокол к Рамочной конвенции ООН об изменении климата. Официальный русский перевод [Текст]. ООН, 1997. - 27 с.

9. Лесной план Республики Башкортостан на период с 2019 по 2018 гг.: утверждён Указом временно исполняющего обязанности Главы Республики Башкортостан от 27 декабря 2018 г. № УГ-340 [Текст]. Уфа: Министерство лесного хозяйства Республики Башкортостан, 2018. 122 с.

10. Национальный доклад о кадастре антропогенных выбросов из источников и абсорбции поглотителями парниковых газов, не регулируемых Монреальским протоколом за 1990-2016 гг. Часть 1 [Текст]. М., 2018. 471 с.

11. Рамочная конвенция $\mathrm{OOH}$ об изменении климата. Официальный русский перевод [Текст]. ООН, 1992. $30 \mathrm{c}$.

12. Сабирзянов, И.Г. Экологический потенциал лесов Республики Башкортостан [Текст] / И.Г. Сабирзянов, К.М. Габдрахимов // Актуальные проблемы лесного комплекса. Информационные материалы международной научно-технической конференции «Лес-2000». Брянск, 2000. С. 28-29.

13. Филипчук, А.Н. Вклад лесов России в углеродный баланс планеты [Текст] / А.Н. Филипчук, Б.Н. Моисеев // Парниковые газы - экологический ресурс России. Международная конференция 16 июня 2004 г. Голицыно, 2004.

14. Чураков, Б.П. Депонирование углерода разновозрастными культурами сосны [Текст]/ Б.П. Чураков, Е.В. Манякина // Ульяновский медико-биологический журнал. 2012. № 1. С. 125129.

15. Султанова, Р.Р. Лесоводственные методы формирования нектарных липняков на Южном Урале [Текст]: автореф. дис. ... доктора сельскохозяйственных наук / Р.Р. Султанова. Екатеринбург: Уральский государственный лесотехнический университет, 2005. $42 \mathrm{c}$.

16. Мартынова, М.В. Состав и биомасса травянистого яруса в нарушенном рубками древостое липы мелколистной [Текст] / М.В. Мартынова, Р.Р. Султанова // Аграрный вестник Урала. 2014. № 10 (128). C. 59-63.

17. Султанова, Р.Р. Формирование нектарных липняков_[Текст] / Р.Р. Султанова, Р.М. Мустафин, К.М. Габдрахимов. Уфа, 2001. 72 с.

18. Султанова, Р.Р. Нектарные липняки [Текст] / Р.P. Султанова, Р.М. Мустафин, А.Ф. Хайретдинов. Уфа, 2002. 125 с.

19. Иванова, О. Парниковый газ. Источники выбросов парниковых газов [электронный ресурс] / О. Иванова. Режим доступа: Https://www. syl.ru/article/288869/new_parnikovyiy-gaz-istoch niki-vyibrosov-parnikovyih-gazov (05.08.2019).

\section{Сведения об авторах}

1. Сабирзянов Ильдар Галиханович, кандидат сельскохозяйственных наук, заведующий кафедрой лесоводства и ландшафтного дизайна, ФГБОУ ВО Башкирский ГАУ, г. Уфа, ул. 50-летия Октября, 34, тел.: (347) 252-72-52, e-mail: Sabirzyanov.63@mail.ru. 
2. Габдрахимов Камиль Махмутович, доктор сельскохозяйственных наук, профессор кафедры лесоводства и ландшафтного дизайна, ФГБОУ ВО Башкирский ГАУ, г. Уфа, ул. 50-летия Октября, 34, тел.: (347) 252-72-52, e-mail: Gabdrahimov@mail.ru.

3. Блонская Любовь Николаевна, кандидат биологических наук, доцент кафедры лесоводства и ландшафтного дизайна, ФГБОУ ВО Башкирский ГАУ, г.Уфа, ул. 50-летия Октября, 34, тел.: (347) 25272-52, e-mail: L.n.blonskaya@mail.ru.

Приведены данные о влиянии углерода на парниковый эффект в атмосфере, о составе земельного фонда Республики Башкортостан, в том числе распределении площади земель сельскохозяйственного назначения и земель лесного фонда. Приведены данные расчёта по нетто-поглощению, потерям и бюджету углерода биомассой лесообразующих лесных древесных растений в лесах в Республике Башкортостан. Дана информация о динамике стока углерода по состоянию на 2007 и 2017 годы в лесах в РБ. Сде- ланы расчёты поглощения углерода биомассой насаждений, в том числе их средних запасов на единице площади в разрезе древесных видов хвойных растений, определены объёмы депонирования углерода. Определены причины уменьшения углеродного стока в лесах. Выделены группы возраста лесных насаждений, древесные виды, имеющие большее депонирование углерода. Предложены мероприятия по повышению депонирования углерода в целях принятия мер по уменьшению парникового эффекта.

I. Sabirzyanov, K. Gabdrakhimov, L. Blonskaya

\section{CARBON SEQUESTRATION IN PLANTS} IN THE REPUBLIC OF BASHKORTOSTAN

Key words: greenhouse gases; carbon sequestration; green plants; net absorption; carbon balance.

\section{Authors' personal details}

1. Sabirzyanov Ildar, Candidate of Agricultural Sciences, head of the Forestry and Landscape Design Department, Federal State Budgetary Educational Institution of Higher Education «Bashkir State Agrarian University», Ufa, 50-letiya Oktyabrya St., 34, phone: (347) 252-72-52, e-mail: Sabirzyanov.63@mail.ru.

2. Gabdrahimov Kamil, Doctor of Agricultural Sciences, Professor of the Forestry and Landscape Design Department, Federal State Budgetary Educational Institution of Higher Education «Bashkir State Agrarian University», Ufa, 50-letiya Oktyabrya St., 34, e-mail: Gabdrahimov@mail.ru.

3. Blonskaya Lyubov, Candidate of Biological Sciences, Associate Professor of the Forestry and Landscape Design Department, Federal State Budgetary Educational Institution of Higher Education «Bashkir State Agrarian University», Ufa, 50-letiya Oktyabrya St., 34, e-mail: L.n.blonskaya@mail.ru.

The article reports the impact of carbon on the greenhouse effect in the atmosphere, the composition of the land Fund of the Republic of Bashkortostan, including the distribution of agricultural land and forest land. Figures of the net carbon captured, lost and the carbon balance in biomass of forest tree species in the Republic of Bashkortostan are presented. Carbon behavior pattern in the forests in the Republic of Bashkortostan is described as of 2007 and 2017. Carbon sequestration in plants is calcu- lated including the average plant reserves per unit area in the context of coniferous tree species. Carbon sequestration capacity is identified. The paper presents causes of low carbon flow in the study forests. The age groups of forest stand as well as tree species with higher carbon capture capacity are revealed. In conclusion, the authors come up with measures to increase carbon sequestration and reduce the greenhouse effect in the long term.

(C) Сабирзянов И.Г., Габдрахимов К.М., Блонская Л.Н. 
УДК 631.811:631.84:633.111.1

DOI: $10.31563 / 1684-7628-2019-51-3-20-26$

Д.В. Чикишев, Н.В. Абрамов, Н.С. Ларина, С.В. Шерстобитов

\section{ВЛИЯНИЕ АЗОТНЫХ УДОБРЕНИЙ НА АМИНОКИСЛОТНЫЙ СОСТАВ ЗЕРНА ЯРОВОЙ ПШЕНИЦЫ}

\section{Ключевые слова: азотные удобрения; яровая пиеница; урожайность; аминокислоты; неорга- нический азот.}

Введение. Очень часто в Тюменской области сельскохозяйственные растения испытывают дефицит доступного азота в почве [1-3]. Его недостаточное количество может стать ограничивающим фактором в получении высокого и качественного урожая. Азотные удобрения представляют собой дополнительный источник доступного азота для растений. Их преимущество заключается в том, что они содержат азот в наиболее растворимых и доступных для растений формах, таких как аммонийная и нитратная.

Неорганический азот легко поглощается корнями растений и в дальнейшем используется для синтеза различных органических веществ, в основном белков [4]. Включение азота в состав белков протекает по следующей цепочке: нитрат-ион - ион аммония - аминокислоты - белки. Реакции трансформации азота из одного соединения в другое протекают с помощью различных ферментов. При их недостаточной активности скорость катализируемых реакций замедляется. В связи с этим часть поступившего в растения минерального азота может накопиться в исходной форме. С другой стороны, непотребившийся растениями минеральный азот из удобрений может являться причиной загрязнения окружающей среды $[5,6]$.

Таким образом, при использовании азотных удобрений важно правильно рассчитать их дозы, а для этого необходимо знать вынос азота растением на единицу продукции, правильно оценить содержание доступного азота в почве перед его внесением и спланировать урожайность. Проблемой при внесении азотных удобрений в почву может являться неоднородность содержания азота на различных участках поля, которая отмечена исследователями [7-9]. Традиционный способ подразумевает внесение минеральных удобрений одной нормой на всё поле с учётом среднего содержания доступного азота на этом поле. Поэтому на участках поля с наиболее выраженным дефицитом азота его внесения будет недостаточно, а на участках с содержанием выше среднего его концентрация в почве будет избыточна. В настоящее время получает распространение технология дифференцированного (точного) внесения минеральных удобрений по элементарным участкам поля с учётом содержания азота на этих участках и планируемой урожайности.

Цель исследования - изучение влияния азотсодержащих удобрений на урожайность, накопление неорганического азота, а также аминокислотного состава в зерне яровой пшеницы. Удобрения на всех вариантах вносились дифференцировано.

Материалы и методы исследования. Опыт заложен в 2016 г. на полях учхоза ГАУ Северного Зауралья. Выращиваемая культура - яровая пшеница сорта Новосибирская 31. Исследования проводились на 4 вариантах с различной планируемой урожайностью: контроль без внесения удобрений $(К)$, внесение удобрений на планируемую урожайность 3 т/га (3), на 4 т/га (4) и 5 т/га (5). Повторность трёхкратная. Элементарные участки имели квадратную форму с размером сторон 50 м (площадь 0,25 га). Применяемые удобрения в опыте - аммиачная селитра $(34,4 \%$ азота) и азофоска (15\% азота, $15 \%$ фосфора и 15 \% калия). Для определения доз удобрений под планируемую урожайность весной в промежуток времени после боронования поля и перед посевом проводился отбор почвы. С каждого участка методом конверта отбиралось по 20 точечных проб в слое почвы 0-30 см, которые были усреднены в объединённую пробу. Отобранные образцы почвы доводились до воздушно-сухого состояния путём их распределения тонким слоем на фильтровальной бумаге при комнатной температуре. Из высушенных образцов вручную отбирались растительные остатки и мелкие камни. Почва размалывалась вручную в фарфоровой чашке и пропускалась через сито с диаметром отверстий 1 мм. Далее проводились анализы почвы на агрохимические показатели: $\mathrm{pH}$ водной и солевой вытяжек, гидролитическая кислотность и сумма поглощенных оснований, содержание в почве нитратного азота, подвижных форм фосфора и калия, извле- 
каемых по методу Чирикова, и содержание гумyса.

Образцы зерна отбирались из комбайна после уборки каждого участка. В дальнейшем пробу зерна перемешивали и размалывали. В подготовленной пробе зерна определяли следующие показатели: содержание азота в форме неорганических соединений - иона аммония и нитрат-иона по ГОСТ Р 56374-2015 и ГОСТ Р 56375-2015, аминокислотный состав по М-0435-2009 (2014), и содержание белка по ГОСТ 10846-91. При определении нитрат-иона навеску зерна массой 0,5 г помещали в коническую колбу и заливали 25 мл дистиллированной воды. Проводили экстракцию в течение 20 минут. С учётом того, что практически все нитраты растворимы в воде, они переходили из зерна в водную вытяжку. Полученную вытяжку фильтровали, отбирали аликвоту объёмом 1 мл, помещали в пробирку эппендорфа и центрифугировали. Далее пробирку помещали в систему капиллярного электрофореза и определяли содержание нитрат-ионов в вытяжке с дальнейшим расчётом содержания нитрат-ионов в зерне. Для определения иона аммония навеску зерна массой 100 мг помещали в термостойкую виалу с герметичной закручивающейся крышкой. Добавляли 10 мл 6М соляной кислоты. Данное количество кислоты по отношению к навеске является избыточным для гидролиза белка из любых проб. Проводили гидролиз в течение 12-14 часов при температуре $110{ }^{\circ} \mathrm{C}$. В процессе гидролиза неорганические катионы полностью переходят из зерна в солянокислую вытяжку. Содержимое охлаждённых виал после гидролиза фильтровали, отбирали аликвоту в фарфоровую чашечку и осторожно выпаривали в струе тёплого воздуха для испарения оставшейся кислоты. Сухой остаток растворяли в воде, помещали в пробирку эппендорфа и центрифугировали. Далее пробирку помещали в систему капиллярного электрофореза и определяли содержание иона аммония.

Анализ зерна на содержание аминокислот проводили тремя различными вытяжками. Из первой вытяжки определяли содержание 14 аминокислот: пролина, аргинина, метионина, треонина, лизина, лейцина, изолейцина, аланина, валина, гистидина, фенилаланина, тирозина, серина, глицина. Начальная пробоподготовка проводится аналогично определению иона аммония, однако после испарения аликвоты в чашечку для выпаривания последовательно добавляются водный раствор карбоната натрия и фенилизотиоцианат в изопропиловом спирте и проводится дериватизация в течение 35 минут. В процессе этой процедуры аминокислоты переводятся в форму фенилтиокарбамильных производных (ФТК-производных). Далее содержимое чашечки с дериватами выпаривали и растворяли в воде, помещали в пробирку эппендорфа и центрифугировали. Пробирку помещали в систему капиллярного электрофореза и определяли содержание ФТК-производных аминокислот.

Для определения сумм глутамина и глутаминовой кислоты, аспарагина и аспарагиновой кислоты, цистина и цистеина проводили предварительное окисление определяемых аминокислот в соответствующие устойчивые к гидролизу кислоты: глутаминовую, аспарагиновую, цистеиновую. Предварительное окисление проводили добавлением к пробе зерна смеси перекиси водорода с муравьиной кислотой. Предварительно окисленную пробу переносили в виалу для гидролиза и поступали аналогично определению других аминокислот.

Для определения триптофана в виалу с помещённой навеской зерна добавляли гидроокись бария. Проводили гидролиз при аналогичных условиях. После гидролиза содержимое виалы количественно переносили в мерную колбу, добавляли индикатор и нейтрализовали избыток щёлочи серной кислотой. Объём в колбе доводили до метки водой, аликвоту помещали в пробирку эппендорфа и центрифугировали. Далее пробирку помещали в систему капиллярного электрофореза и определяли прямое содержание триптофана (а не в форме ФТК-производных, как другие аминокислоты).

Так как цистеин, цистин, аспарагин и глутамин являются неустойчивыми к гидролизу аминокислотами, то при определении иона аммония результаты его содержания могут быть немного завышены.

Результаты исследования. На основе полевых опытов различными авторами установлено, что в зависимости от условий выращивания урожайность яровой пшеницы в условиях Тюменской области и соседних регионов может изменяться в широких пределах и достигать 6,0 т/га [10-12]. Наше исследование показало, что применение минеральных удобрений в условиях недостатка питательных элементов в почве способствует увеличению урожайности яровой пшеницы относительно контрольного варианта, где удобрения не вносились [13]. Максимальная эффективность применения удобрений была отмечена в варианте с планируемой урожайностью 4 т/га, где внесли 390 кг/га минеральных удобрений в физическом весе и получили 
5,40 т/га зерна (такое несовпадение между фактически полученной и планируемой урожайностью зерна вызвано несовершенством применяемой методики для расчёта доз минеральных удобрений). По сравнению с контрольным вари- антом, где получили 3,78 т/га зерна, прибавка составила 1,62 т/га (42 \%). Дополнительное внесение минеральных удобрений не позволило получить более высокий урожай, даже несколько его снизив.

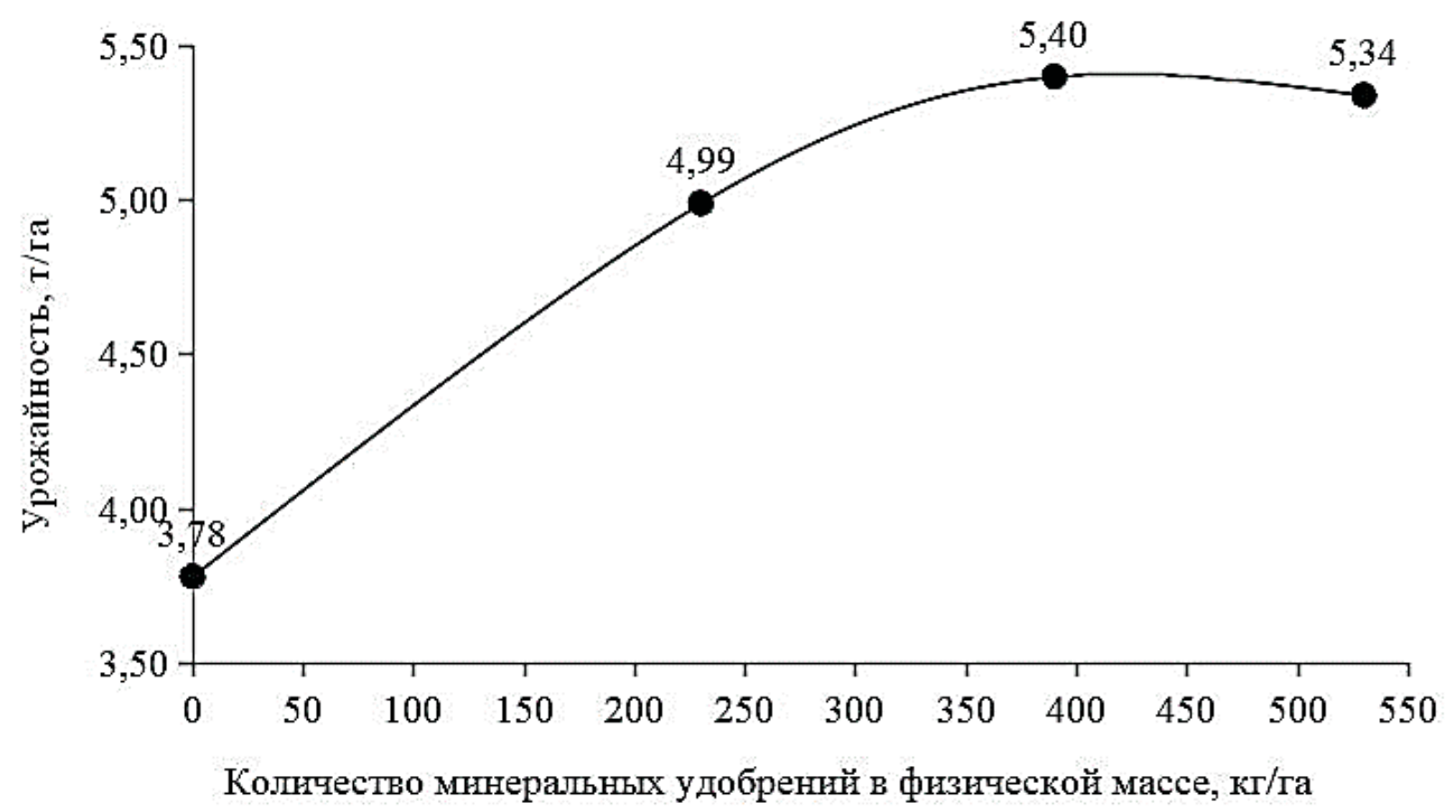

\footnotetext{
Рисунок 1

Влияние доз внесения минеральных удобрений на урожайность яровой пшеницы $(\mathrm{n}=3, \mathrm{P}=0,95)$
}

Применяемые в опыте удобрения - аммиачная селитра $\left(\mathrm{NH}_{4} \mathrm{NO}_{3}\right)$ и азофоска $\left(\mathrm{NH}_{4} \mathrm{H}_{2} \mathrm{PO}_{4}\right.$ * $\left.\mathrm{NH}_{4} \mathrm{NO}_{3}{ }^{*} \mathrm{KCl}\right)$ - содержат азот в аммонийной и нитратной формах, и с увеличением дозы их внесения количество доступного азота в почве также будет повышаться. Обе эти формы азота являются основными при питании растений азотом и могут легко поглощаться корнями. Опыт показал, что яровая пшеница накапливает неорганический азот преимущественно в аммонийной форме. Восстановление нитратов идёт по следующей схеме: нитрат-ион - нитрит-ион - гипонитрит-ион - гидроксиламин - ион аммония. Для ферментов, восстанавливающих нитрат-ион до иона аммония, на различных этапах необходимы: молибден, медь, железо и марганец [14]. Так как содержание аммонийного азота $(0,40-0,59 \%$ в пересчёте иона аммония на азот) в зерне значительно превышало содержание нитратного азота $(0,016-0,020 \%$ в пересчёте нитрат-иона на азот), можно сделать вывод, что обеспеченность пшеницы на чернозёме указанными микроэлементами достаточная (рисунок 2).
Аммонийный азот растения используют для синтеза аминокислот. Основные пути их синтеза: прямое аминирование и трансаминирование кетокислот под действием соответствующих ферментов, количество и активность которых влияет на скорость катализируемых ими реакций. Повышение содержания иона аммония в зерне говорит о том, что накопленный аммонийный азот не успевает включиться в состав аминокислот.

Для устранения его избытка растения начинают образовывать аспарагин и глутамин, которые являются амидами аспарагиновой и глутаминовой кислот и в отличие от иона аммония для растений не токсичны $[15,16]$. Результаты наших исследований показали, что преимущественно образуется глутамин (таблица 1). Это связано с тем, что глутаминовая кислота (предшественник глутамина) является доминирующей в аминокислотном составе основного белка яровой пшеницы - глютена [17]. Причём с увеличением содержания иона аммония, глутаминовой кислоты и глутамина заметно снижение содержания аргинина, путь синтеза которого до- 
вольно большой и занимает 8 стадий. Растение начинает устранять избыток токсичного для него иона аммония по самому простому пути в ущерб синтезу аргинина и, вероятно, других со- единений. Несбалансированное азотное питание может являться причиной снижения урожайности.

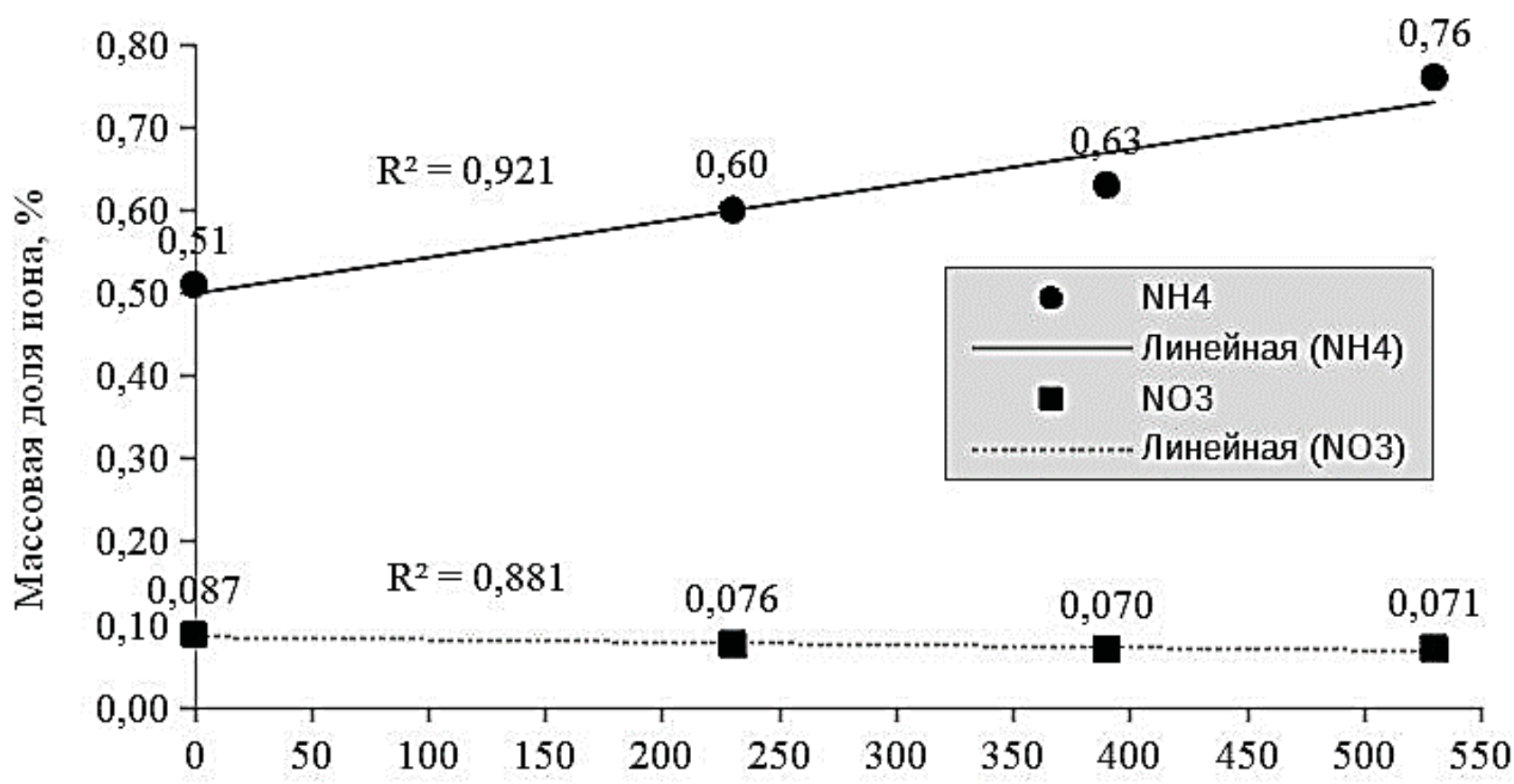

Колнчество мннеральньх удобреннй в физнческой массе, кг/га

Рисунок 2

Влияние доз удобрений на содержание нитрат-иона и иона аммония в зерне яровой пшеницы $(\mathrm{n}=3, \mathrm{P}=0,95)$

Существуют исследования, доказывающие, что избыток иона аммония может накапливаться также и при недостатке углеводов [14]. В основе их образования лежит процесс фотосинтеза процесс формирования углеводов с использованием углекислого газа, воды и солнечной энергии. В период исследования гидротермический коэффициент Селянинова составил 1,3, что соответствовало достаточному уровню увлажнения. Замеры энергии света не входили в про- грамму исследований. Концентрация аминокислот других семейств мало зависела от доз применяемых удобрений. Так, например, содержание лизина в зерне яровой пшеницы находилось на контрольном варианте и без применения минеральных удобрений составило 0,3 \%, а при внесении различных доз минеральных удобрений - 0,4 \%. Содержание тирозина на всех исследуемых вариантах находилось в пределах 0,4-0,5 \% (таблица 2).

Таблица 1 Содержание аминокислот семейства $\alpha$-кетоглутурата в зерне яровой пшеницы $(\mathrm{n}=3, \mathrm{P}=0,95)$

\begin{tabular}{|c|c|c|c|}
\hline Вариант опыта & $\begin{array}{c}\text { Глутаминовая кислота }+ \\
\text { глутамин }\end{array}$ & Пролин & Аргинин \\
\hline К & $\underline{3,6 \pm 1,8}$ & $\underline{1,3 \pm 0,2}$ & $\underline{5,1 \pm 1,6}$ \\
\hline 3 & $\underline{4,8 \div 4,2}$ & $\underline{4,5 \pm 1,4}$ & $\underline{4,2 \pm 5,0}$ \\
\hline 4 & $\underline{3,9 \div 5,0}$ & $\underline{1,6 \pm 0,1}$ & $\underline{1,5}$ \\
\hline 5 & $\underline{5,4 \pm 2,1}$ & $\underline{1,5 \pm 2,1,6}$ & $0,7 \div 2,4$ \\
\hline
\end{tabular}


Таблица 2 Содержание аминокислот $(\mathrm{n}=3, \mathrm{P}=0,95)$

\begin{tabular}{|c|c|c|c|c|c|c|c|}
\hline $\begin{array}{c}\text { Вариант } \\
\text { опыта }\end{array}$ & $\begin{array}{c}\text { Аспарагино- } \\
\text { вая к-та + } \\
\text { аспарагин }\end{array}$ & Метионин & Треонин & Лизин & $\begin{array}{c}\text { Лейцин + } \\
\text { изолейцин * }\end{array}$ & Аланин & Валин \\
\hline Семейство & \multicolumn{4}{|c|}{ Оксалоацетата } & \multicolumn{3}{|c|}{ Пирувата } \\
\hline K & $<0,5$ & $<\frac{0,3 \pm 0,0}{<0,25 \div 0,3}$ & $\begin{array}{l}0,6 \pm 0,1 \\
0,5 \div 0,6\end{array}$ & $\frac{0,3 \pm 0,0}{0,3 \div 0,3}$ & $\frac{1,2 \pm 0,1}{1,1 \div 1,2}$ & $\begin{array}{l}0,5 \pm 0,1 \\
0,4 \div 0,5\end{array}$ & $<0,5$ \\
\hline 3 & $<0,5$ & $<0, \frac{<0,25}{<0,25 \div 0,3}$ & $\frac{0,6 \pm 0,1}{0,6 \div 0,7}$ & $\frac{0,4 \pm 0,0}{0,4 \div 0,4}$ & $\frac{1,3 \pm 0,3}{1,2 \div 1,4}$ & $\frac{0,6 \pm 0,1}{0,5 \div 0,6}$ & $\frac{0,6 \pm 0,0}{0,6 \div 0,6}$ \\
\hline 4 & $<0,5$ & $<0, \underline{0,3}=0,4$ & $\frac{0,6 \pm 0,4}{0,5 \div 0,8}$ & $\frac{0,4 \pm 0,2}{0,3 \div 0,5}$ & $\frac{1,3 \pm 0,7}{1,1 \div 1,6}$ & $\frac{0,5 \pm 0,0}{0,5 \div 0,5}$ & $\frac{0,6 \pm 0,2}{<0,5 \div 0,7}$ \\
\hline 5 & $<0,5$ & $\underline{0,4 \pm 0,2}$ & $\frac{0,6 \pm 0,2}{0,5 \div 0,7}$ & $\frac{0,4 \pm 0,0}{0,4 \div 0,4}$ & $\frac{1,4 \pm 0,1}{1,3 \div 1,4}$ & $\frac{0,5 \pm 0,1}{0,5 \div 0,6}$ & $\frac{0,5 \pm 0,1}{0,5 \div 0,6}$ \\
\hline
\end{tabular}

* Содержание лейцина и изолейцина определено суммарно. Изолейцин относится к семейству оксалоацетата, а лейцин пирувата.

Таблица 2 (продолжение) Содержание аминокислот ( $\mathrm{n}=3, \mathrm{P}=0,95)$

\begin{tabular}{|c|c|c|c|c|c|c|c|}
\hline $\begin{array}{c}\text { Вариант } \\
\text { опыта }\end{array}$ & Гистидин & Фенилаланин & Тирозин & Триптофан & Серин & $\begin{array}{l}\text { Цистин + } \\
\text { Цистеин* }\end{array}$ & Глицин \\
\hline Семейство & $\begin{array}{c}\text { Рибозо- } \\
\text { 5-фосфата }\end{array}$ & \multicolumn{3}{|c|}{ Фосфоенолпирувата + эритрозо-4-фосфата } & \multicolumn{3}{|c|}{ 3-фосфоглицерата } \\
\hline K & $<0,5$ & $\frac{0,7 \pm 0,3}{0,6 \div 0,8}$ & $\frac{0,4 \pm 0,1}{0,4 \div 0,5}$ & $\frac{0,3 \pm 0,1}{0,2 \div 0,3}$ & $\underline{0,8 \pm 0,1}$ & $<0,1$ & $\frac{0,6 \pm 0,1}{0,5 \div 0,6}$ \\
\hline 3 & $<0,5$ & $\frac{0,6 \pm 0,1}{0,6 \div 0,7}$ & $\frac{0,4 \pm 0,2}{0,3 \div 0,5}$ & $\frac{0,2 \pm 0,1}{0,2 \div 0,3}$ & $\frac{1,0 \pm 0,2}{0,9 \div 1,0}$ & $<0,1$ & $\frac{0,6 \pm 0,0}{0,6 \div 0,6}$ \\
\hline 4 & $<0,5$ & 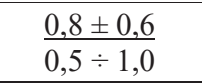 & $\frac{0,5 \pm 0,1}{0,4 \div 0,5}$ & $\frac{0,2 \pm 0,0}{0,2 \div 0,2}$ & $\frac{0,9 \pm 0,3}{0,8 \div 1,0}$ & $<0,1$ & $\frac{0,9 \pm 0,8}{0,6 \div 1,2}$ \\
\hline 5 & $<0,5$ & 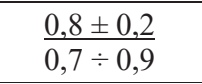 & $\frac{0,5 \pm 0,3}{0,4 \div 0,6}$ & $\frac{0,2 \pm 0,1}{0,2 \div 0,3}$ & $\begin{array}{l}1,0 \pm 0,1 \\
0,9 \div 1,0\end{array}$ & $<0,1$ & $\frac{0,6 \pm 0,1}{0,6 \div 0,7}$ \\
\hline
\end{tabular}

* Содержание цистина и цистеина определено суммарно.

Выводы. Применение минеральных азотных удобрений способствует увеличению урожайности яровой пшеницы до 1,62 т/га (42% относительно контрольного варианта). Неорганический азот из почвы и удобрений, усвоившись растением, восстанавливается до иона аммония и включается в состав аминокислот. Его избыток, достигающий $0,76 \%$, спровоцирован биологическими факторами - недостаточным количеством и активностью ферментов, необходимых для его нейтрализации, и условиями внеш- ней среды - недостатком солнечной энергии. При обильном азотном питании яровой пшеницы и накоплении в ней токсичного иона аммония в растении включаются механизмы нейтрализации его избыточного количества путём включения аммония в состав глутамина в ущерб синтезу аргинина. Избыточные дозы минеральных удобрений снижают урожайность зерна яровой пшеницы, а также могут являться причиной загрязнения внешней среды.

\section{Библиографический список}

1. Абрамов, Н.В. Дифференцированное внесение минеральных удобрений с использованием космических систем [Текст] / Н.В. Абрамов, С.В. Шерстобитов, О.Н. Абрамов // Агропродовольственная политика России. 2014. № 2 (26). C. 2-8.

2. Дёмин, Е.А. Азотный режим кукурузы, выращенной по зерновой технологии в лесостепной зоне Зауралья [Текст] / Е.А. Дёмин, Д.И. Ерёмин // Вестник Алтайского государственного аграрного университета. 2017. № 12 (158). C. $10-16$.
3. Рыбников, В.С. Агроэкологическая оценка почв $3 \mathrm{AO}$ «Успенское» Тюменского района [Текст] / В.С. Рыбников // Мир инноваций. 2018. № 1-2. C. 64-74.

4. Leghari S.J., Wahocho N.A., Laghari G.M., Talpur K.H. and Wahocho S.A. and Lashari A.A. (2016). Role of nitrogen for plant growth and development: A review. Advances in Environmental Biology (Jordon), 10(9): 209-2018.

5. Khan M.N., Mobin M., Abbas Z.K. and Alamri S.A. (2018) Fertilizers and Their Contaminants in Soils, Surface and Groundwater. In: Domi- 
nick A. DellaSala, and Michael I. Goldstein (eds.) The Encyclopedia of the Anthropocene, vol. 5, p. 225-240. Oxford: Elsevier.

6. Гречишкина, Ю.И. Экологические аспекты применения удобрений в современном земледелии [Текст] / Ю.И. Гречишкина, А.Н. Есаулко, Л.С. Горбатко, А.А. Беловолова, С.А. Коростылев, Т.С. Айсанов // Вестник АПК Ставрополья. 2012. № 3 (7). С. 112-115.

7. Денисов, К.Е. Повышение экономической эффективности растениеводства на основе дифференцированного внесения удобрений в системе точного земледелия [Текст] / К.Е. Денисов, К.А. Петров, Н.С. Григорьев // Наука вчера, сегодня, завтра. 2016. № 5-2 (27). С. 72-76.

8. Балабанов, В.И. Дифференцированное внесение удобрений в точном земледелии [Текст] / В.И. Балабанов, Е.В. Березовский, А.И. Беленков, С.В. Железова // Фермер. Поволжье. 2016. № 2 (44). С. 61-63.

9. Długosz J., Piotrowska-Długosz A. (2016). Spatial variability of soil nitrogen forms and the activity of N-cycle enzymes. Plant Soil Environ, Vol. 62, 2016, No. 11: 502-507.

10. Галеев, Р.Р. Урожайность и качество зерна сортов яровой мягкой пшеницы в зависимости от уровня интенсификации производства в лесостепи Приобья [Текст] / Р.Р. Галеев, И.С. Самарин // Вестник Новосибирского государственного аграрного университета. 2018. № 1 (46). C. 9-15.

11. Рзаева, В.В. Урожайность яровой пшеницы в зависимости от основной обработки почвы и предшественника возделываемой в Тю- менской области [Текст] / В.В. Рзаева // EUROPEAN RESEARCH: сборник статей XI Международной научно-практической конференции. Пенза: Наука и Просвещение. 2017. C. $115-117$.

12. Волынкина, О.В. Фосфорное удобрение усиливает действие азота на урожай и качество пшеницы [Текст] / О.В. Волынкина // Проблемы агрохимии и экологии. 2019. № 1. С. 21-25.

13. Чикишев, Д.В. Влияние дифференцированного внесения минеральных удобрений на продуктивность и качество яровой пшеницы [Электронный ресурс] / Д.В. Чикишев, Н.В. Абрамов, Н.С. Ларина // АгроЭкоИнфо. 2019. № 2. Режим доступа: http://agroecoinfo.narod.ru/ journal/STATYI/2019/2/st_237.doc.

14. Агрохимия / Под ред. акад. В.М. Клечковского и засл. деятеля науки А.В. Петербургского. Изд. 2-е, испр. и доп. М.: Колос, 1967. C. $183-185$.

15. Causin H.F., Barneix A.J. The effect of glutamine and asparagine on net $\mathrm{NH} 4+$ uptake in young wheat plants. Plant and Soil, 1994, Volume 161, Number 2, Pages 257-265.

16. Joy W.K. 2011. Ammonia, glutamine and asparagine: A carbon-nitrogen interface. Canadian Journal of Botany. 66. 2103-2109.

17. Ine Rombouts, Lieve Lamberts, Inge Celus, Bert Lagrain, Kristof Brijs, Jan A. Delcour Wheat gluten amino acid composition analysis by highperformance anion-exchange chromatography with integrated pulsed amperometric detection. Journal of Chromatography A, Volume 1216, Issue 29, 17 July 2009, Pages 5557-5562.

\section{Сведения об авторах}

1. Чикишев Дмитрий Владимирович, аспирант, ФГБОУ ВО ГАУ Северного Зауралья, г. Тюмень, ул. Республики, д. 7, e-mail: 79088690714@yandex.ru.

2. Абрамов Николай Васильевич, доктор сельскохозяйственных наук, профессор, заведующий кафедрой почвоведения и агрохимии, ФГБОУ ВО ГАУ Северного Зауралья, г. Тюмень, ул. Республики, д.7, e-mail: vip.anv.55@mail.ru.

3. Ларина Наталья Сергеевна, кандидат химических наук, профессор, профессор кафедры органической и экологической химии, ФГАОУ ВО Тюменский государственный университет, г. Тюмень, ул. Володарского, д. 6, e-mail: nslarina@yandex.ru.

4. Шерстобитов Сергей Владимирович, кандидат сельскохозяйственных наук, доцент, доцент кафедры почвоведения и агрохимии, ФГБОУ ВО ГАУ Северного Зауралья, г. Тюмень, ул. Республики, д.7, e-mail: sv5888857@yandex.ru.

В статье представлены результаты применения азотных минеральных удобрений под яровую пшеницу сорта Новосибирская 31. Их применение позволило дополнительно получить 1,62 т/га зерна относительно контрольного варианта. Максимальная урожайность составила 5,40 т/га. С увеличением доз минеральных удоб-

рений повышается содержание иона аммония в зерне, которое достигает 0,76 \%. Его избыток яровая пшеница нейтрализует путём включения в состав глутамина, содержание которого доходит до 5,4 \%. При этом синтез аргинина снижается с 5,1 до $1,0 \%$. 


\section{EFFECT OF NITROGEN FERTILIZERS ON AMINO ACID COMPOSITION OF SPRING WHEAT GRAIN}

Key words: nitrogen fertilizers; spring wheat; yield; amino acids; inorganic nitrogen.

\section{Authors' personal details}

1. Chikishev Dmitry, Post-graduate student, Federal State Budgetary Educational Institution of Higher Education «Northern Trans-Ural State Agricultural University», Russia, Tyumen, Respubliki St., 7, e-mail: 79088690714@yandex.ru.

2. Abramov Nikolay, Doctor of Agricultural Sciences, Professor, Head of the Department of Soil Science and Agrochemistry, Federal State Budgetary Educational Institution of Higher Education «Northern TransUral State Agricultural University», Russia, Tyumen, Respubliki St., 7, e-mail: vip.anv.55@mail.ru.

3. Larina Natalia, Candidate of Chemical Sciences, Professor, Professor of the Department of Organic and Ecological Chemistry, Federal State Autonomous Educational Institution of Higher Education «Tyumen State University», Russia, Tyumen, Volodarskogo St., 6, e-mail: nslarina@yandex.ru.

4. Sherstobitov Sergey, Candidate of Agricultural Sciences, Associate Professor, Associate Professor of the Department of Soil Science and Agrochemistry, Federal State Budgetary Educational Institution of Higher Education «Northern Trans-Ural State Agricultural University», Russia, Tyumen, Respublika St., 7, e-mail: sv5888857@yandex.ru.

The paper presents the results of applying nitrogen fertilizers for spring wheat of the Novosibirsk 31 variety. The use of the fertilizers produced additional 1,62 t/ha of grain relative to the control variant. The maximum yield was $5,4 \mathrm{t} / \mathrm{ha}$. The increased doses of the mineral fertilizers resulted in the increased ammonium ion in the grain, the rate reached $0,76 \%$. The excess of ammonium ion in spring wheat is neutralized by glutamine in the composition; the glutamine content reached $5,4 \%$. At the same time, the synthesis of arginine was reduced from 5,1 to $1,0 \%$.

(C) Чикишев Д.В., Абрамов Н.В., Ларина Н.С., Шерстобитов С.В.

УДК 636.92:612.11:612.53

DOI: 10.31563/1684-7628-2019-51-3-26-31

Е.А. Ажмулдинов, Ю.Н. Чернышенко, М.Г. Титов

\section{ФИЗИОЛОГИЧЕСКОЕ СОСТОЯНИЕ И ПРОДУКТИВНОСТЬ ЖИВОТНЫХ ПРИ ВОЗДЕЙСТВИИ ТЕПЛОВОГО СТРЕССА}

\section{Ключевые слова: кролики; стресс; температура; физиологические показатели; кровь.}

Введение. Кролики очень чувствительны к неблагоприятным условиям окружающей среды, особенно высоким температурам. Они приспосабливаются к холоду, главным образом, уменьшая потери тепла через кожу. Терморегуляция у кроликов довольно бедна, так как у них мало функциональных желез. Пониженная способность к терморегуляции у кроликов объясняется слабо развитой потовой железой: у большинства из них она не функционирует и пот вы- деляется путем изменения частоты дыхания. Комфортный температурный режим для нормальной жизнедеятельности кроликов - от 15 до $20^{\circ} \mathrm{C}$. Кролики, подвергнутые воздействию температуры окружающей среды $25{ }^{\circ} \mathrm{C}$, имели более низкий прирост массы тела, чем содержащиеся при $15{ }^{\circ} \mathrm{C}$. Высокая температур (от 30 до $35^{\circ} \mathrm{C}$ ) способствует увеличению скорости метаболизма на $20 \%$ и снижению потребления корма. Критическая температура окружающей 
среды для кролика $27-28^{\circ} \mathrm{C}$, при этом начинает работать химическое регулирование температуры его тела. Когда температура воздуха поднимается за верхний предел диапазона термонейтральности $\left(32{ }^{\circ} \mathrm{C}\right)$, физическая регуляция температуры тела происходит путем подъема сосудов ближе к коже и выделения пота. В общем, постоянное воздействие повышенных температур приводит к отклонению от норм физиологических и биологических механизмов с последующим повреждением многих органов [1, 2]. Известно, что при гипертермии у кроликов увеличиваются сердцебиение, температура тела, частота дыхания, а также повышается уровень эритроцитов, лейкоцитов, глюкозы и других параметров, характеризующих биохимический состав крови [3-5]. Важным фактором, влияющим на продуктивные и физиологические качества кроликов, считается тепловой стресс. Поэтому температура тела используется во многих исследованиях как основной показатель реакции животных на колебания температуры окружающей среды. Данных о физиологических показателях кроликов при воздействии температурного стресса очень мало. Исходя из этого, изучение влияния высокой температуры на их физиологические функции является актуальной проблемой и представляет определенный научный и практический интерес.

Цель и задачи исследования. Целью проведенных исследований являлось изучение влияния теплового стресса на продуктивные качества и физиологическое состояние кроликов. Задачи исследований - определить особенности роста и провести сравнительную оценку физиологического состояния на основе морфологического и биохимического состава крови у кроликов при воздействии теплового стресса.

Условия, материалы и методы исследования. Эксперименты были выполнены в соответствии с инструкциями и рекомендациями Russian Regulations, 1987 (Order No. 755 on 12.08. 1977 the USSR Ministry of Health) and «The Guide for Care and Use of Laboratory Animals (National Academy Press Washington, D.C. 1996)». При выполнении исследований были предприняты меры по сведению к минимуму страдания изучаемого объекта и уменьшению числа используемых образцов. Исследования проводили на 6 кроликах-самцах 5-месячного возраста в стандартных условиях вивария. Средняя начальная масса тела кроликов - 1551 г. В течение 14 дней они адаптировались к новым условиям содержа- ния. После подготовительного периода их разделили на две группы по 3 головы: контрольную и опытную. Тепловой стресс создавали с помощью тепловой пушки. Продолжительность воздействия составляла 3 часа при температуре $+42{ }^{\circ} \mathrm{C}$ и влажности $75 \%$. Живая масса тела регистрировалась до и после теплового стресса. Определяли частоту пульса, дыхания, температуру тела. Кровь для биохимического анализа у животных отбирали из краевой ушной вены. Биохимический анализ сыворотки крови выполняли на автоматическом анализаторе CS-T240 («DIRUI Industrial Co., Ltd», Китай) с коммерческими наборами для ветеринарии (ДиаВетТест, ЗАО «ДИАКОН-ДС», Россия; «Randox Laboratories Ltd», Великобритания), взвешивание проводилось на электронных весах Momert 6550 (производитель MOMERT Co Ltd, Венгрия), температура определялась электронным термометром. Основной материал, полученный в исследованиях, обработан с использованием пакета программ «Statistica 10.0» («Stat Soft Inc.», США). Хранение полученных результатов исследования и первичную обработку материала осуществляли в оригинальной базе данных «Microsoft Excel 2010».

Результаты исследования. Терморегуляция у кроликов довольно слабая, так как у них мало функциональных потовых желез. Перегрев организма оказывает сверхотрицательное влияние на их физиологическое состояние. Для создания оптимальных условий содержания целесообразно контролировать микроклимат в местах их обитания. Заранее обнаруженные перепады температуры, а также других параметров микроклимата и правильные корректирующие действия могут снизить их пагубное влияние [13]. Проведенные исследования различных ученых свидетельствуют об угнетении секреции желудочного сока при воздействии высоких температур. Происходит торможение секреции ферментов поджелудочной железы, угнетается моторика кишечника [3]. Соответственно снижается аппетит, а следовательно, падает продуктивность. Снижение живой массы за период опыта наблюдалось в обеих группах, но в большей степени в опытной по сравнению с контролем после теплового стресса (таблица 1). При тепловом стрессе потери массы тела в опытной группе увеличились на $2,0 \%$, а в контрольной они были в пределах $0,2 \%$.

Высокая температура окружающей среды стимулирует передачу сигнала тепловым рецеп- 
торам, подавляющим нервные импульсы к центру аппетита в гипоталамусе, вызывающие снижение потребления корма. Это может способствовать спаду биосинтеза белка и меньшему отложению жиров, что приводит к снижению живой массы. В этот период происходит увеличение потребления воды [6].

В ответ на тепловой стресс организм снижает температуру тела повышенным пото- и слюноотделением и увеличивает частоту дыхания. В результате этого часть энергии, использовавшейся ранее для прироста живой массы, пе- ренаправляется на терморегуляцию [8]. Исследователи отмечают, что уже при температуре в помещениях $+28 \ldots+29{ }^{\circ} \mathrm{C}$ у животных увеличивается в 1,5 раза интенсивность дыхания, а пульс - на 20-30 ударов в минуту. Частота пульса не проявлялась в согласованной и определенной тенденции с изменяющимися условиями окружающей среды. Некоторые исследователи наблюдали уменьшение частоты пульса, тогда как другие - увеличение при повышении температуры окружающей среды [10].

Таблица 1 Живая масса кроликов, г

\begin{tabular}{|l|c|c|}
\hline \multirow{2}{*}{\multicolumn{1}{|c|}{ Показатель }} & \multicolumn{2}{|c|}{ Группа } \\
\cline { 2 - 3 } & контрольная & опытная \\
\hline До воздействия стресс-фактора & $1694 \pm 1,05$ & $1681 \pm 1,03$ \\
\hline После воздействия стресс-фактора & $1690 \pm 1,02$ & $1647 \pm 1,07$ \\
\hline
\end{tabular}

Частота пульса отражает, прежде всего, гомеостаз, циркулирующий наряду с общим метаболическим статусом. При повышении температуры пульс заметно учащается [6]. Кролики, подвергнутые воздействию теплового стресса, показали более высокую частоту пульса (на 6,6 \%) по сравнению с животными контрольной группы (таблица 2).

Таблица 2 Физиологические показатели

\begin{tabular}{|l|c|c|}
\hline \multirow{2}{*}{\multicolumn{1}{|c|}{ Показатель }} & \multicolumn{2}{|c|}{ Группа } \\
\cline { 2 - 3 } & контрольная & опытная \\
\hline Частота пульса в мин & $152 \pm 0,94$ & $162 \pm 0,90$ \\
\hline Частота дыхания в мин & $122 \pm 0,83$ & $140 \pm 0,87$ \\
\hline Температура тела, ${ }^{\circ} \mathrm{C}$ & $38,9 \pm 0,98$ & $39,7 \pm 0,95$ \\
\hline
\end{tabular}

Частота дыхания и ректальная температура оказались более чувствительными показателями теплового напряжения, чем частота пульса. Учащение частоты дыхания с увеличением температуры окружающей среды свидетельствует о высокой положительной корреляции между этими показателями [7]. Увеличение частоты дыхания при тепловом стрессе позволило животному рассеять избыточное тепло тела, испаряя больше влаги в выдыхаемом воздухе [8]. При сравнительном анализе физиологических показателей была установлена значительная разница в ректальной температуре на 2,1 \% и частоты дыхания на 14,8 \% выше у кроликов опытной группы, чем у контрольных сверстников. Эти результаты согласуются с данными других ученых [9]. Повышение температуры тела можно объяснить тем, что при воздействии данного стресс-фактора происходит увеличение скорости метаболизма, приводящее к гипертермическому эффекту у животного [10]. Через учащен- ное дыхание они снижают эту гипертермию, что составляет около $30 \%$ от общей теплоотдачи. Анализ полученных в ходе эксперимента данных выявил выраженную реакцию крови на тепловое воздействие: ее показатели повысились у животных по отношению к контрольным сверстникам (таблица 3).

Из данных физиологических показателей видно, что кролики обеих групп были здоровыми и имели высокую продуктивность. В результате воздействия температурного стресса физиологическое состояние животных опытной группы значительно изменилось. Характеристика морфологических показателей крови животных, находящихся в условиях стресса, показала отрицательное его воздействие на адаптационные механизмы организма, выразившиеся в увеличении количества эритроцитов, концентрации гемоглобина и гематокрита на 1,1-3,6 \%. Увеличилось количество лимфоцитов на $12,0 \%$, а лейкоцитов - на 4,5 \% по сравнению с показа- 
телями сверстников, которые находились в комфортных условиях. Это можно объяснить механизмом развития стресса, а именно: в организме возникает недостаток кислорода, который восполняется увеличением количества эритроцитов в крови и соответственно уровня гемоглобина, что дает возможность для менее травмирующей адаптации животных к изменяющимся условиям среды.

При воздействии высокой температуры изменялась биохимическая картина крови (таблица 4). По результатам биохимических показателей сыворотки крови животных на фоне стресса наблюдалось повышение содержания общего белка, глюкозы и других компонентов, что свидетельствует об усилении в их организме белкового и липидного обменов, транспортировки питательных веществ для клеточных структур, защиты организма от неблагоприятных факторов внешней среды. В опытной группе наблюдается повышение уровня общего белка на 4,3 \% (P < 0,05). Происходит увеличение доли альбумина на 3,6 \% (P < 0,05). Содержание билирубина было выше на 20,9 \% (P < 0,001). Общее количество холестерина было повышено на 8,5 \% (P < 0,01), а уровень глюкозы в крови был выше у кроликов, подверженных тепловому стрессу, на 14,1 \%. Участие глюкозы в энергетическом обмене во время стресса привело к тому, что ее количественное определение стало полезным инструментом для оценки стресса [4].

Таблица 3 Морфологический состав крови

\begin{tabular}{|l|c|c|}
\hline \multirow{2}{*}{\multicolumn{1}{|c|}{ Показатель }} & \multicolumn{2}{|c|}{ Группа } \\
\cline { 2 - 3 } & контрольная & опытная \\
\hline Лейкоциты, $10^{9} /$ л & $6,60 \pm 0,39$ & $6,90 \pm 0,42$ \\
\hline Лимфоциты, $\%$ & $42,10 \pm 0,35$ & $43,80 \pm 0,38$ \\
\hline Лимфоциты, $10^{9} /$ л & $2,50 \pm 0,52$ & $2,80 \pm 0,48$ \\
\hline Эритроциты, $10^{12} /$ л & $3,79 \pm 0,41$ & $3,83 \pm 0,44$ \\
\hline Гемоглобин, г/л & $89,00 \pm 0,43$ & $91,00 \pm 0,40$ \\
\hline Гематокрит, $\%$ & $25,20 \pm 0,40$ & $26,10 \pm 0,51$ \\
\hline Тромбоциты, $10^{9} /$ л & $177,00 \pm 0,39$ & $161,00 \pm 0,48$ \\
\hline
\end{tabular}

Таблица 4 Биохимические показатели крови

\begin{tabular}{|l|c|c|}
\hline \multirow{2}{*}{\multicolumn{1}{|c|}{ Показатель }} & \multicolumn{2}{|c|}{ Группа } \\
\cline { 2 - 3 } & контрольная & опытная \\
\hline Глюкоза, ммоль/л & $6,87 \pm 0,12$ & $7,84 \pm 0,14$ \\
\hline Общий белок, г/л & $55,14 \pm 0,27$ & $37,49 \pm 0,31$ \\
\hline Альбумин, г/л & $30,00 \pm 0,35$ & $87,60 \pm 0,15$ \\
\hline АЛТ, Ед/л & $74,90 \pm 0,11$ & $58,80 \pm 0,03$ \\
\hline АСТ, Ед/л & $53,50 \pm 0,02$ & $1,68 \pm 0,05$ \\
\hline Билирубин, мкмоль/л & $1,39 \pm 0,03$ & $1,41 \pm 0,44$ \\
\hline Холестерин, ммоль/л & $1,30 \pm 0,42$ & $3,77 \pm 0,23$ \\
\hline Са, ммоль/л & $3,58 \pm 0,26$ & $29,90 \pm 0,38$ \\
\hline Fе, мкмоль/л & $29,50 \pm 0,41$ & $0,78 \pm 0,55$ \\
\hline Мg, ммоль/л & $0,71 \pm 0,53$ & $3,78 \pm 0,47$ \\
\hline Р, ммоль/л & $3,51 \pm 0,44$ & $350,00 \pm 0,28$ \\
\hline Щел. фосфотаза, Ед/л & $370,0 \pm 0,25$ & \\
\hline
\end{tabular}

Увеличение содержания глюкозы в сыворотке крови при воздействии повышенной температуры может характеризовать наличие у животных стресс-реакции, при развитии которой происходит выброс в кровь катехоламинов, которые мобилизуют энергетические резервы ор- ганизма (гликоген печени и мышц) для преодоления чрезмерного стрессорного воздействия [8, 9]. Активность ферментов АЛТ и АСТ значительно возросла у всех животных во время стресса на 17,0 ( $<<0,001)$ и 9,9 \% $(\mathrm{P}<0,001)$ соответственно. Уровень щелочной фосфотазы 
после воздействия теплового стресса снизился у особей опытной группы на $5,4 \%(\mathrm{P}<0,05)$ по сравнению с контролем.

Выводы. При анализе результатов влияния теплового стресса на организм кроликов были выявлены значительные изменения в физиологических и гематологических показателях, что говорит об отрицательном воздействии повышенных температур на организм животных.

\section{Библиографический список}

1. Кизаев, М.А. Влияние кратковременной тепловой нагрузки на биохимические показатели крови животных [Текст] / М.А. Кизаев, М.Г. Титов, Т.В. Казакова, О.В. Маршинская, С.В. Нотова // Мясное скотоводство - приоритеты и перспективы развития: материалы международной научно-практической конференции / Под общ. ред. С.А. Мирошникова. Оренбург: ФНЦ БСТ РАН, 2018. С. 186-189.

2. Косова, Т.И. Кролики: разведение, выращивание, кормление [Текст] / Т.И. Косова, С.Н. Александров. М.: АСТ, Сталкер, 2004. $120 \mathrm{c}$.

3. Marder J., Eylath U., Moskovitz E., Sharir R. The effect of heat exposure on blood chemistry of the hyperthermic rabbit. J. Comparative Biochemistry and Physiology. № 97 (2). P. 245.

4. Nakyinsige K., Sazili A.Q., Aghwan Z.A., Zulkifli I., Goh Y.M., Fatimah A.B. Changes in Blood Constituents of Rabbits Subjected to Transportation under Hot, Humid Tropical Conditions. Asian-Australasian Journal of Animal Sciences. 2013. № 26 (6). P. 874-878.

5. Миронова, И.В. Показатели крови кроликов при включении в рацион пробиотической кормовой добавки Биогумитель [Текст] / И.В. Миронова, Е.Н. Черненков, А.А. Черненкова // Известия Оренбургского государственного аграрного университета. 2017. № 1 (63). C. 212-215.
6. Liste M.G., María G.A., García-Belenguer S., Chacón G., Gazzola P., Villarroel M. The effect of transport time, season and position on the truck on stress response in rabbits. J. World Rabbit Science. 2008. № 16. P. 229-235.

7. Левахин, В.И. Морфологические и биохимические показатели крови бычков при технологических стрессах [Текст] / В.И. Левахин, Е.А. Ажмулдинов, М.Г. Титов, М.М. Поберухин, И.А. Бабичева // Вестник мясного скотоводства. 2017. № 2 (98). С. 88-92.

8. Левахин, В.И. Физиологические показатели бычков в период стрессовой нагрузки при скармливании антистрессовых препаратов [Текст] / В.И. Левахин, Е.А. Ажмулдинов, Ю.А. Ласыгина, М.Г. Титов, Ф.Х. Сиразетдинов, Н.И. Рябов // Вестник мясного скотоводства. 2016. № 3 (95). С. 80-84.

9. Кизаев, М.А. Физиологические показатели бычков чёрно-пёстрой породы при воздействии транспортного стресса [Текст] / М.А. Кизаев, Е.А. Ажмулдинов, М.Г. Титов, Н.В. Соболева // Животноводство и кормопроизводство. 2018. T. 101. № 3. С. 39-44.

10. Миронова, И.В. Естественная резистентность кроликов при скармливании пробиотической кормовой добавки Биогумитель [Текст] / И.В. Миронова, Е.Н. Черненков // Известия Оренбургского государственного аграрного университета. 2017. № 1 (63). С. 115-117.

\section{Сведения об авторах}

1. Ажсмулдинов Елемес Ажмулдинович, доктор сельскохозяйственных наук, профессор, главный научный сотрудник отдела технологии мясного скотоводства и производства говядины, ФГБНУ «Федеральный научный центр биологических систем и агротехнологий Российской академии наук», 460000, г. Оренбург, ул. 9 Января, 29, тел.: (3532) 43-46-78.

2. Чернышенко Юлия Николаевна, кандидат химических наук, доцент кафедры «Технология мясных, молочных продуктов и химии», ФГБОУ ВО Башкирский ГАУ, 450001, Приволжский федеральный округ, Республика Башкортостан, г.Уфа, ул. 50-летия Октября, 34, тел.: (347) 228-07-19.

3. Титов Максим Геннадвевич, кандидат сельскохозяйственных наук, старший научный сотрудник отдела технологии мясного скотоводства и производства говядины, ФГБНУ «Федеральный научный центр биологических систем и агротехнологий Российской академии наук», 460000, г. Оренбург, ул. 9 Января, 29, тел.: (3532) 43-46-78, e-mail: titow.ru@mail.ru. 
Было проведено исследование влияния теплового стресса на клинико-физиологическое состояние кроликов-самцов 5-месячного возраста со средней живой массой 1551 г. Максимальная температура воздействия во время эксперимента составляла $+42{ }^{\circ} \mathrm{C}$. Результаты исследования показали, что при этом уменьшилось поедание корма, увеличилось потребление воды, сни- зилась живая масса. Также высокая температура отрицательно сказалась на физиологических функциях, отражаемых морфологическими и биохимическими параметрами крови, - увеличением показателей гемоглобина, эритроцитов, лейкоцитов, общего белка плазмы, альбуминов и холестерина в период действия данного стресс-фактора.

E. Azhmuldinov, Yu. Chernyshenko, M. Titov

\section{PHYSIOLOGICAL STATE AND PRODUCTIVITY OF ANIMALS UNDER THERMAL STRESS}

\section{Key words: rabbits; stress; temperature; physiological indicators; blood.}

\section{Authors' personal details}

1. Azhmuldinov Elemes, Doctor of Agricultural Sciences, Professor, Chief Researcher of the Department of Technology of Meat Cattle Breeding and Beef Production, Federal Scientific Center for Biological Systems and Agrotechnologies of the Russian Academy of Sciences, 460000, Orenburg, 9 January St., 29, phone: (3532) 43-46-78.

2. Chernyshenko Yulia, Candidate of Chemical Sciences, Associate Professor of the Department of Technology of Meat, Dairy Products and Chemistry, Federal State Budgetary Educational Institution of Higher Education «Bashkir State Agrarian University», Bashkortostan, Ufa, 50-letiya Oktyabrya St., 34, phone: (347) 228-07-19.

3. Titov Maxim, Candidate of Agricultural Sciences, Senior Researcher, Department of Beef Cattle Breeding and Beef Production, Federal Research Center for Biological Systems and Agrotechnologies, Russian Academy of Sciences, 460000, Orenburg, 9 January St., 29, phone: (3532) 43-46-78, e-mail: titow.ru @mail.ru.

A study was conducted of the effect of heat stress on the clinical and physiological state of male rabbits at the age of 5 months with an average live weight of $1551 \mathrm{~g}$. The maximum temperature the animals were exposed to during the experiment was $+42{ }^{\circ} \mathrm{C}$. The study results showed a decrease in feed intake and an increase in water consumption, which contributed to a decrease in live weight. Hematolog-

(C) Ажмулдинов Е.А., Чернышенко Ю.Н., Титов М.Г. ical parameters, including hemoglobin, erythrocytes, leukocytes, total plasma protein, globulins and cholesterol increased during the action of this stress factor. It was found that the effect of high ambient temperatures on rabbits negatively affected their physiological functions; the negative effect was reflected by the morphological and biochemical blood parameters.

УДК 619.616.98:085

DOI: 10.31563/1684-7628-2019-51-3-31-35

А.В. Альдяков, С.Г. Кондручина

\section{ВИСЦЕРАЛЬНАЯ БЛОКАДА ТЕЛЯТ ПРИ ГАСТРОЭНТЕРИТЕ}

\section{Ключевые слова: гастроэнтерит; антибиотики; висцеральная блокада; телята; новокаин.}

Введение. Желудочно-кишечные заболевания относятся к серьезным и тяжелым и пред- ставляют немалую, нередко неизлечимую опасность для животных. В современных условиях 
выращивания телят в хозяйствах предупреждение подобных заболеваний производится в основном за счет ветеринарной профилактики, особых условий зоогигиенического содержания и кормления. В настоящее время часто встречаются различные виды гастроэнтеритов: катаральные, серозные, фибринозные, гнойные и геморрагические. Многие ветеринарные специалисты считают, что основной причиной подобных болезней у телят являются неправильное кормление, резкий переход на грубые корма. Склонность к гастроэнтериту наблюдается у телят, рожденных от коров, получающих не сбалансированные по составу корма. Это заболевание протекает в острой форме, длится долго, приводит к интоксикации, понижению температуры и обезвоживанию $[5,6]$. При заболевании органов пищеварения в основном используют антибиотики широкого спектра действия в сочетании с витаминными и минеральными препаратами. Основное направление лечения болезни кишечника у телят - это подавление патогенных микроорганизмов в тонком и толстом отделах кишечника и поддержание обмена веществ в организме. Во врачебной практике используют новокаиновые блокады для снятия сенсибилизации, спазма гладкой мускулатуры, снижения возбудимости периферических холинергических систем и уменьшения образования ацетилхолина [1-3, 7]. До настоящего времени лечение острых желудочно-кишечных заболеваний остается актуальной проблемой, так как количество больных с острыми гастроэнтеритами различной этиологии продолжает расти. Несмотря на введение новых методов заблаговременной диагностики гастроэнтерита, количество летальных случаев при данной патологии остается достаточно высоким. Многие случаи летальных исходов объясняются отсутствием у ветеринарных врачей необходимых знаний обо всех тонкостях диагностики желудочно-кишечных заболеваний и способах их лечения [4].

Целью нашей работы является изучение степени влияния на организм телят для излечения гастроэнтерита висцеральной новокаиновой блокады совместно с антибиотиками.

Методы и материалы. Объектом исследования являлись животные, имеющие ярко выраженную симптоматику гастроэнтерита. Животные были разделены на контрольную и опытную группы. Диагноз заболевания был поставлен на основе данных клинической картины крови при ее лабораторном исследовании. Биохимический анализ крови проводился по 7 показателям, гематологический - по 3. Из клинических показателей учитывались следующие: общее состоя- ние и особенности поведения животных, температура их тела, частота дыхания, результаты пальпации брюшной стенки. Уточнялись данные о его длительности, первоначальных проявлениях заболевания, характере поражения желудочно-кишечного тракта. Животным контрольной группы внутрибрюшинно вводили 0,25 \% теплый раствор новокаина в дозе 1 мл на кг живой массы с бициллином 7000 ЕД/кг один раз в течение трех суток. Опытной группе инъецировали внутримышечно Нитокс в дозе 1 мл на 10 кг массы животного и повторили через 72 часа. Большое значение имело применение методов укрепления резистентности и иммунологической реактивности организма [8]. В качестве заместительной (заменяющей) терапии в контрольной и опытной группах применялся инъекционный раствор суперамина-С, который обычно используется для улучшения углеводного обмена, профилактики авитаминоза и при недостаточном количестве аминокислот у животных. Раствор суперамина-С вводили телятам внутримышечно в дозе 1 мл на 4,5 кг массы тела через семь суток. Для определения прироста живой массы телят один раз в месяц индивидуально взвешивали. Во время нашей работы мы наблюдали за состоянием органов пищеварения и обменными процессами. Исследования организма телят в возрасте от двух до пяти месяцев производились в УНПЦ «Студенческий» ФГБОУ ВО Чувашского ГСХА. В ветеринарной лаборатории Чувашской ГСХА проводились гематологические и биохимические исследования.

Результаты исследования. При постановке диагноза учитывались эпизоотологические данные, клинико-морфологические признаки, результаты лабораторных исследований, условия кормления и содержания животных. Терапевтические мероприятия при заболеваниях органов пищеварения телят проводились исходя из причин их возникновения и особенностей протекания. Было установлено, что у животных постепенно происходило усиление перистальтики кишечника, снижался аппетит, наблюдались угнетенное состояние, изменения в дыхательной и сердечно-сосудистой системах и повышение температуры тела. Животные мало двигались, больше лежали, потребляли корм в недостаточном количестве, не реагировали на окружающие раздражители. Нарушения при содержании и кормлении коров до и после родов явились тем фактором, который, прежде всего, приводил к появлению заболеваний желудочно-кишечного тракта. В начальный период болезни температура организма животных оставалась в пределах физиологической нормы или слегка изменялась. 
Количество дыхательных движений и частота пульса менялись незначительно, намечалась тенденция в сторону некоторого увеличения. Начальная стадия гастроэнтерита характеризовалась незначительным увеличением гиперемии, слизистых оболочек ротовой полости, истечения при этом не наблюдались. Слизистая оболочка носовой полости была гиперемированной, влажной, ее целостность оставалась ненарушенной, наблюдались прозрачные водянистые необильные истечения, наложений, инородных тел и язвы не обнаружено.

У животных после введения новокаина в брюшную полость наблюдалось незначительное увеличение дыхательного движения грудной клетки и пульса, а также повышение температуры на $0,5^{\circ}$. Общее состояние животных в результате внутрибрюшинного введения 0,5 \% новокаина с бициллином не претерпело явных изменений. Кроме того, было выявлено, что телята мало двигались, иногда проявляли незначительное беспокойство, спокойно стояли, что указывает на естественное воздействие новокаина на центральную нервную систему. Время пребывания бициллина в организме животных при гастроэнтерите было обусловлено их функциональным состоянием. Раствор бициллина с новокаином поступал в кровь животных при внутрибрюшинном введении гораздо быстрее, чем при внутримышечном.

Таблица 1 Морфологические показатели крови телят при терапии гастроэнтерита

\begin{tabular}{|c|c|c|}
\hline \multirow{2}{*}{ Показатель крови } & \multicolumn{2}{|c|}{ Группа телят } \\
\hline & контрольная & опытная \\
\hline \multicolumn{3}{|c|}{ до применения препаратов } \\
\hline Гемоглобин, г/л & $98,2 \pm 1,16$ & $97,8 \pm 1,11$ \\
\hline Эритроциты, $10^{12} / л$ & $6,4 \pm 0,26$ & $6,3 \pm 0,32$ \\
\hline Лейкоциты, $10^{9} /$ л & $7,6 \pm 0,65$ & $7,5 \pm 0,44$ \\
\hline \multicolumn{3}{|c|}{ на 7 сутки } \\
\hline Гемоглобин, г/л & $102,7 \pm 1,54$ & $101,8 \pm 1,2$ \\
\hline Эритроциты, $10^{12} / л$ & $7,8 \pm 0,28$ & $7,9 \pm 0,56$ \\
\hline Лейкоциты, 109/л & $8,9 \pm 0,15$ & $9,0 \pm 0,19$ \\
\hline \multicolumn{3}{|c|}{ на 15 сутки } \\
\hline Гемоглобин, г/л & $109,5 \pm 0,56$ & $112,5 \pm 1,25$ \\
\hline Эритроциты, $10^{12} /$ л & $7,9 \pm 0,18$ & $7,9 \pm 0,08$ \\
\hline Лейкоциты, $10^{9} / л$ & $8,4 \pm 0,32$ & $8,01 \pm 0,11$ \\
\hline
\end{tabular}

Кровь для исследования брали стерильными внутривенными иглами разного размера (в зависимости от возраста животного) из яремной вены. Сосудами для сбора крови послужили специально предназначенные для гематологического анализа стерильные и вакуумные пробирки с активатором свертывания гелем для биохимического анализа. Данные, представленные в таблице 1 , удостоверяют, что гематологические показатели крови телят контрольной и опытной групп до введения лекарственных препаратов - фоновые показатели гемоглобина, эритроцита и лейкоцита - были в пределах близких величин. В контрольной группе на 7-е сутки гемоглобин увеличился на 4,5 \% по сравнению с периодом, предшествующим введению лекарственных препаратов, и на 0,9 \% по сравнению с опытной группой. А на 15 -е сутки наблюдалось повышение гемоглобина по сравнению с предшествующими данными: на 7 -е сутки - на 6,2 \%, а в опытной группе - на 9,2 \%. Нами была выявлена позитивная динамика концентрации гемоглобина в крови контрольной и опытной групп телят.

Количество эритроцитов в крови телят контрольной и опытной групп соответствовало показателям изменений концентрации гемоглобина. До введения препарата содержание эритроцитов в контрольной группе было $6,4 \pm 0,26 *$ $10^{12} /$, в дальнейшем отмечалось увеличение их количества по сравнению с предыдущими периодами на $17,9 \%$ и $18,9 \%$, а при сравнении с показателями опытной группы наблюдалось увеличение на $20 \%$. Содержание лейкоцитов у телят подверглось изменениям, в контрольной группе на 7-е сутки отмечалось их увеличение на $14,6 \%$, а в последующем - снижение на 9,5\%, в опытной группе - на 16,6 \%, 6,3\% соответственно. Такая динамика являлась положительной для телят и контрольной, и опытной групп. 
До введения препаратов общий белок, каротин, кальций, фосфор, резервная щелочность, сахар в контрольной и опытной группах были в пределах одинаковых величин и в последующие сроки не выходили за принятые нормативные показатели. В контрольной группе телят на 7-е сутки увеличилось содержание общего белка до $12,3 \%$, кальция - до $6,5 \%$, на 15 -е сутки - до $3 \%$, в опытной группе общий белок на 7-е сутки - до 9,8\%, кальций - до 10,2 \%, на 15 -е сутки до $12,2 \%$ и $12,5 \%$ соответственно. Увеличение уровня каротина способствует его благоприятному влиянию на обменный процесс, так как он обладает иммуномодулирующими свойствами, участвует в синтезе жирных кислот, усиливает скорость гликолиза в мышцах, почках и печени, подавляет аргиназную активность пепсина, увеличивает активность инсулина, адреналина и улучшает функцию половых желез.

Результаты исследований свидетельствуют о том, что при лечении гастроэнтерита введение новокаина в органы брюшной полости не приводит к выраженному терапевтическому эффекту. Однако после введения в низких концентрациях раствора новокаина в брюшную полость в очагах воспаления наступают положительные сдвиги. Новокаин, обладая нейротропностью, оказывает положительный эффект непосредственно на звенья рефлекторной дуги. Благоприятное лечебное воздействие новокаина проявляется и в его положительном воздействии на центральную нервную систему. Введение бициллина с новокаином в брюшную полость не оказало значительного влияния на поведение телят.

Внутримышечное введение нитокса, входящего в состав препарата окситетрациклина дигидрат, действует бактериостатически на большинство грамположительных и грамотрицательных бактерий и быстро всасывается в кровь. Его лечебный эффект в сыворотке крови сохраняется 3 суток. Препарат выводится преимущественно с мочой и желчью. Пролонгированное действие нитокса обусловлено его составом, в который входит комплекс препаратов: окситетрациклина дигидрат с магнием. Окситетрациклина дигидрат подавляет в микроорганизме процесс синтеза белка. При аллергических реакциях телятам внутривенно вводили препарат кальция борглюконата.
При внутрибрюшинном введении 0,5 \% раствора новокаина с бициллином в контрольной группе клинические признаки гастроэнтерита стали исчезать на 4 сутки, в опытной группе на 5 сутки. В конце исследований у животных контрольных и опытных групп улучшился аппетит, сформированные каловые массы и температура тела были в пределах физиологической нормы.

Актуальность исследования проблемы возникновения желудочно-кишечных заболеваний и способов их лечения объясняется многими причинами, среди которых следует, прежде всего, назвать высокую распространенность заболеваний, осложняющихся гастроэнтеритами, трудность ранней диагностики их причин. Положительный эффект антибиотикотерапии связан, прежде всего, с применением ее на ранних сроках начала болезни, так как это позволяет практически сразу купировать очаг воспаления, предупреждает развитие бактериемии и метастазирования болезни. При этом следует учитывать механизм действия антибактериального препарата на микробную клетку и на организм животного. Лечебный эффект при внутрибрюшинном введении новокаина связывают с непосредственным воздействием его на рецепторы серозных покровов кишечника, желудка и брыжеечного нервного сплетения. Применение висцеральной новокаиновой блокады с антибиотиками при лечении животных, больных гастроэнтеритом, способствует незначительному изменению крови. Это связано с диффузным всасыванием новокаина и общим действием на организм животного препарата суперамина-С, увеличением фагоцитарной активности лейкоцитов, улучшением обменных процессов и оказанием бактерицидного воздействия антибиотиков на патогенную микрофлору. Длительность гастроэнтерита зависит от возраста, состояния организма, возможностей устранения вызвавших его причин, своевременности и правильности оказания врачебного лечения. Исход лечения животных при желудочно-кишечных заболеваниях во многом определяется организацией и своевременным проведением мероприятий, связанных с оказанием лечебной помощи и профилактикой заболеваний.

\section{Библиографический список}

1. Варганов, А.И. Обезболивание и новокаиновая терапия [Текст] / А.И. Варганов, В.Г. Чупраков, В.А. Созинов. Киров: Вятка, 2001. 320 с.
2. Зайцева, М.Н. Применение новокаина в хирургической операции [Текст] / М.Н. Зайцева // Студенческая наука - первый шаг в академи- 
ческую науку: сборник материалов студенческой научно-практической конференции. Чебоксары: ЧГСХА, 2013. $331 \mathrm{c.}$

3. Новокаиновые блокады, применяемые в ветеринарной терапии [Текст] / С.С. Абрамов, А.А. Белко, Ю.К. Коваленок, А.А. Мацинович. Минск, 2001. 22 c.

4. Новокаин в ветеринарной медицине [Текст]: учебное пособие для студентов вузов / В.П. Лабинов, А.С. Зенкин, С.В. Лабинов. Саранск: Морд. ун-т, 2000. 110 с.

5. Лекарственные средства для ветеринарного применения в России [Текст]: справочник. М.: Видаль Рус, 2017. 448 с.
6. Субботин, В.В. Основные элементы профилактики желудочно-кишечной патологии новорожденных животных [Текст] / В.В. Субботин // Ветеринария. 2004. № 1. С. 36-39.

7. Смирнов, Л.Г. Внутрибрюшинное введение новокаина с пенициллином при диспепсии телят [Текст] / Л.Г. Смирнов // Ветеринария. 1965. № 4. C. 67-69.

8. Шакуров, М.Ш. Новокаиновые блокады в ветеринарии [Текст] / М.Ш. Шакуров, С.В. Тимофеев, И.Г. Галимзянов. М.: Колос, 2007. 72 с.

\section{Сведения об авторах}

1. Альдяков Алексей Владимирович, кандидат ветеринарных наук, доцент кафедры морфологии, акушерства и терапии, ФГБОУ ВО «Чувашская государственная сельскохозяйственная академия», 428003, Чувашская Республика, г. Чебоксары, ул. К. Маркса, 29, e-mail: aav050857@mail.ru.

2. Кондручина Светлана Геннадьевна, кандидат ветеринарных наук, доцент кафедры морфологии, акушерства и терапии, ФГБОУ ВО «Чувашская государственная сельскохозяйственная академия», 428003, Чувашская Республика, г. Чебоксары, ул. К. Маркса, 29, e-mail: kondruchina@yandex.ru.

В статье рассматривается вопрос применения патогенетической терапии при лечении внутрибрюшинных незаразных болезней животных. Было установлено, что лечение телят, больных гастроэнтеритом, с применением висцеральной блокады с антибиотиками способствует незначительному изменению крови. Описаны результаты комплексного лечения телят при гастроэнтерите с помощью соответствующей витаминотерапии, а также при введении внутрибрюшинно новокаина, использовании пролонгированных антибиотиков, бициллина, нитокса.

V. Aldyakov, S. Kondruchina

\section{VISCERAL PROCAINE BLOCKADE AT GASTROENTERITIS IN CALVES}

Key words: gastroenteritis; antibiotics; visceral blockade; calves; novocaine.

\section{Authors' personal details}

1. Aldyakov Alexey, Candidate of Veterinary Sciences, Associate Professor of the Department of Morphology, Obstetrics and Therapy, Chuvash State Agricultural Academy, 428003, Chuvash Republic, Cheboksary, K. Marx St., 29, e-mail: aav050857@mail.ru.

2. Kondruchina Svetlana, Candidate of Veterinary Sciences, Associate Professor of the Department of Morphology, Obstetrics and Therapy, Chuvash State Agricultural Academy, 428003, Chuvash Republic, Cheboksary, K. Marx St., 29, e-mail: kondruchina@yandex.ru.

The paper considers the use of pathogenetic therapy for peritoneal noninfectious diseases in animals. It was found that visceral procaine blockade at gastroenteritis in calves resulted in minor changes of blood. The results of the complex treatment of gastroenteritis in calves are described: vitamin therapy, intraperitoneal novocaine injections, use of prolonged antibiotics, Bicillinum, Nitox.

(C) Альдяков А.В., Кондручина С.Г. 
УДК 619:612.35:639.122

DOI: 10.31563/1684-7628-2019-51-3-36-41

Г.З. Бронникова, Е.Н. Сковородин

\title{
УЛЬТРАСТРУКТУРА И КАРИОЦИТОМЕТРИЯ ГЕПАТОЦИТОВ ПЕРЕПЕЛОВ
}

\author{
Ключевые слова: перепела; печень; гепатоциты; ультраструктура; клеточные органеллы; ка- \\ риоцитометрия; ядра гепатоцитов; ядрышки клеток.
}

Введение. Морфологическое исследование печени, особенно с использованием электронной микроскопии и кариоцитометрии, занимает в современной гепатологии особое место, т. к. позволяет наиболее точно оценить морфофункциональное состояние органа и дать оценку влияния препаратов, используемых для профилактики гепатопатий [4]. Морфология печени пернатых различных видов изучена довольно подробно, но имеется мало работ по кариоцитометрии и ультраструктуре гепатоцитов птиц при использовании кормовых добавок и микроэлементов $[1,2]$. Исследования, посвященные ультраструктуре гепатоцитов перепелов с использованием количественных кариоцитометрических методов, в доступной литературе отсутствуют.

Цель и задачи исследования: изучить функциональную морфологию гепатоцитов перепелов в норме.

Материал и методы исследования. Провели электронно-микроскопическое исследование печени перепелов и помощью кариоцитометрии количественно оценили структуру ядра и ядрышка.

Использовали печень десяти клинически здоровых перепелов месячного возраста, выведенных в КФХ и содержащихся в условиях вивария кафедры. Рацион кормления и условия содержания соответствовали зоотехническим нормам. Все эксперименты были проведены методом острого обескровливания после эфирного наркоза с соблюдением требований «Европейской конвенции о защите позвоночных животных, используемых для экспериментальных и научных целей», в соответствии с законодательством Российской Федерации (Закон РФ «О ветеринарии»; Уголовный кодекс Российской Федерации. Ст. 245. «Жестокое обращение с животными»; приказом Министерства здравоохранения № 755 от 12 августа 1977 г. «О мерах по дальнейшему совершенствованию организационных форм работы с использованием экспериментальных животных») [5-8]. Для электронной микроскопии материал фиксировали в охлажденном 2,5 \% глютаральдегиде на фосфатном буфере с $\mathrm{pH} 7,3$. Фиксировали в $1 \%$ растворе ос- миевой кислоты на фосфатном буфере. Кусочки заливали в эпон-аралдит. Ультратонкие срезы монтировали, контрастировали цитратом свинца и просматривали в электронном микроскопе при увеличении до 30000. Измерения проводили с помощью миллиметровых линеек и методом точечного счета. Объем ядра и ядрышек определяли по формуле:

$$
V=\frac{\pi}{6} \times L \times B^{2},
$$

где $L$ - длинный диаметр, $B$ - короткий диаметр.

Результаты исследований и их обсуждение. Установили, что гепатоциты представляют собой полигональную клетку диаметром 510 мкм. Они имеют два полюса - синусоидальный и билиарный, различающиеся характером расположения органелл. Цитоплазма гепатоцитов характеризуется наличием большого количества митохондрий округлой или вытянутой формы диаметром от 1-1,5 мкм и длиной на продольных срезах до 3 мкм. Встречаются гантелевидные, вероятно делящиеся митохондрии. При этом в некоторых гепатоцитах преобладают митохондрии округлой формы, в других вытянутые до нескольких микрон. С чем это связано? По нашему мнению, это объясняется однонаправленностью митохондриальной сети в гепатоцитах вытянутой формы и плотным расположением митохондриальных тяжей, что характерно для печени перепелов (рисунки 1,8 ). Митохондрии имеют характерное строение, содержат значительное число расширенных, полукруглых коротких крист, расположенных по периферии и не доходящих до середины органеллы. Некоторые кристы на фоне электронноплотного гранулированного матрикса выглядят светлыми, а в митохондриях относительно светлого матрикса - темными со светлой серединой (рисунки 2, 3). В светлых гепатоцитах чаще встречаются митохондрии небольшой величины с множеством мелких крист. Митохондрии гепатоцитов располагаются в околоядерной зоне, на синусоидальном и билиарных полюсах. Функции митохондрий связаны со способностью «хранить» энергию в фосфатных связях АТФ, окислением трикарбоновых и жирных кислот, синтезом мочевой кислоты и других веществ. 
Синтетическая активность клеток связана с их количеством и морфологией. Количество митохондрий может увеличиваться. Это особенно ярко выражено при делении, увеличении функциональной активности клетки. Происходит постоянное обновление митохондрий [3]. Мы наблюдали большее количество митохондрий и большую величину этих ультраструктур в крупных клетках с большим светлым ядром и ядрышком гранулированного типа. В двуядерных гепатоцитах митохондрий больше и они крупнее. В гепатоцитах перепелов хорошо развита цитоплазматическая сеть. При электронно-микроскопическом исследовании она выявляется в виде ограниченных мембранных канальцев и везикул. Зернистая цитоплазматическая сеть (ЗЦС) покрыта рибосомами. Гладкая цитоплазматическая сеть (ГЦС) лишена рибосом. Соотношение ЗЦС и ГЦС различно в зависимости от функционального состояния клетки и видовых особенностей организма. У крыс ЗЦС составляет более 60 \%, у мышей ЗЦС преобладает над ГЦС, у собак это соотношение изменено в сторону ГЦС, у человека относительное содержание ЗЦС и ГЦС составляет соответственно 25 и 75 \% всей цитоплазматической сети [4].

ЗЦС перепелов представлена главным образом плоскими цистернами, лежащими чаще всего близко к митохондриям, окружая их частично или полукругом, образуя своеобразную «шапочку» (рисунок 2), или вокруг митохондрии в виде кольца (рисунки 4, 9). Последнее чаще наблюдается в двуядерных гепатоцитах. Если в срезе видны удлиненные митохондрии, профили ЗЦС располагаются близко между ними в виде тяжей (рисунок 1). Описанная картина является видовой особенностью гепатоцитов перепелов. Цистерны ЗЦС в гепатоцитах перепелов, в отличие от млекопитающих животных, фрагментированы, не образуют стопок параллельно расположенных мембран. ГЦС гепатоцитов у перепелов представлена двумя типами: первым - преобладающим, который имеет вид везикул различных размеров и форм, чаще диаметром 0,1 мкм (рисунки 1, 3); вторым плотно упакованными мембранами без выраженных полостей. Функциональное значение указанных типов ГЦС не выяснено. Первый тип располагается преимущественно на билиарном полюсе гепатоцита.

Кроме того, в цитоплазме гепатоцитов перепелов встречаются лизосомы, периксомы, пластинчатый комплекс, филаментозные структуры, липиды, гликоген. Но наибольшую информативность для оценки функционального состояния гепатоцитов имеет ядро и располага- ющееся в нем структуры и ядрышко. Ядра гепатоцитов имеют преимущественно округлую, овальную форму, редко они выглядят овально вытянутыми. Величина ядра колеблется от 4 до 6 мкм. Интегрирующим показателем размеров ядра является его объем, рассчитываемый по указанной выше формуле на основе короткого и длинного диаметров. Этот показатель колеблется от 21 до 81 мкм $^{3}$. Во всех ультратонких срезах гепатоцитах перепелок, прошедших через ядро, видны ядрышки, в которых можно различить следующие пять компонентов: гранулярный компонент, фибриллярные центры, плотный фибриллярный компонент, хроматин, белковый сетчатый матрикс. Ретикулярный или нуклеолонемный, компактный, кольцевидный, остаточный (покоящийся), сегрегированный типы ядрышек различают на основании преобладания какого-то компонента.

Ультраструктура ядрышек гепатоцитов характеризуется волокнистой и сетчатой структурами, заключенными в плотную диффузную массу, которая окружает гранулярную структуру с низкой плотностью и формирует фибриллярные центры. Вокруг ядрышек выявляется компактная зона хроматина (околоядрышкового), который виден не только по периферии, но и между петлями гранулярного компонента. Структура и величина ядрышек тесно коррелирует с синтетической активностью клетки. Кроме того, установлено, что действие различных веществ (антибиотиков, токсинов, лекарств) вызывает в клетках падение синтетической активности и в первую очередь активности ядрышек, проявляющей морфологическими изменениями. Кариометрия ядрышек и ядер позволяет выявить закономерности изменения объема ядрышек при разных функциональных состояниях и сравнить их с ультраструктурными изменениями ядра и цитоплазмы. Установили, что величина ядрышек гепатоцитов перепелок колеблется от 1 до 2,5 мкм. Наиболее точным и информативным, по нашему мнению, является такой показатель, как объем ядрышка, поскольку эти структуры имеют округлую или овальную форму. Установили, что объем ядрышек варьирует от 0,2 до 9 мкм ${ }^{3}$, что существенно коррелирует с гранулярно-фибриллярной структурой этой органеллы, объемом ядра и количеством митохондрий и гранулярной эндоплазматической сети. Ядрышки объемом от 0,2 до 0,5 мкм $^{3}$ встречаются у $25 \%$ гепатоцитов. Такие ядрышки располагаются эксцентрично или ближе к центру ядра, имеют округлую форму. Они не обладают нуклеонемной гранулярной структурой (рисунки 4, 5), плотные, состоящие 
из тесно расположенных тонких фибрилл. Гранул в них совсем нет или же одиночные гранулы встречаются иногда по периферии. Такую структуру можно отнести к сжатому фибриллярному типу или компактному типу строения ядрышка. Более крупные ядрышки, величина которых достигает 0,5-1 мкм ${ }^{3}$, встречаются чаще (35\%). Они становятся более светлыми за счет снижения осмиофильных свойств и в них появляется небольшой светлый участок, окруженный плотным фибриллярным компонентом фибриллярный центр, а по периферии располагаются крупные участки конденсированного хроматина, так называемые «спутники» ядрышка (рисунок 6). Еще более крупные ядрышки (1-6 мкм ${ }^{3}$ ) встречаются в $35 \%$ случаев. Они становятся еще более светлыми, в них увеличивается гранулярная часть, они приобретают неправильную форму за счет инвагинаций и выступов, растут величина фибриллярных центров до 0,55 мкм и их количество; число «спутников» увеличивается до трех (рисунки 1, 10-12). Крупные гипертрофированные ядрышки, объем которых достигает 9 мкм $^{3}$, встречается в 5 \% гепатоцитов. У них нуклеонемная часть выражена хорошо, они богаты гранулами, фибриллярные зоны невелики и не выделены в обособленные участки, не всегда имеются фибриллярные центры вследствие декоденсации, наблюдается

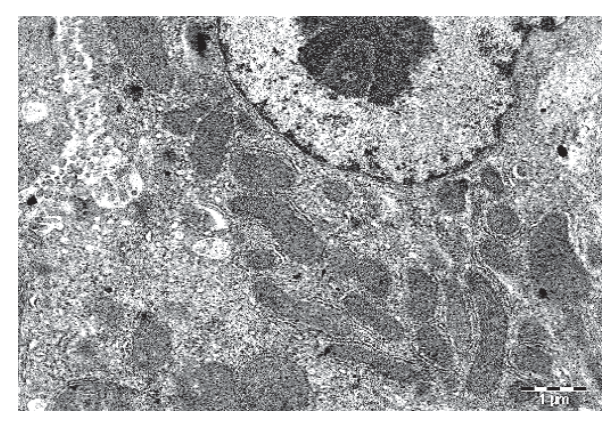

Рисунок 1

Билиарный полюс гепатоцита. Ув. 8000

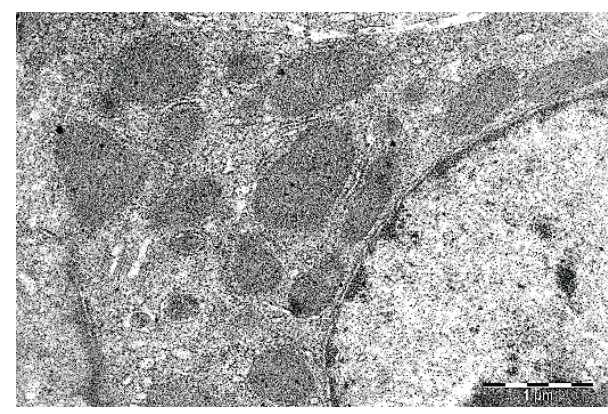

Рисунок 3

Цитоплазма и фрагмент ядра гепатоцита. Ув. 16000 проникновение светлого ядерного вещества, за счет чего создается впечатление разделения ядрышка (рисунок 8). Такую структуру можно отнести к ретикулярному типу ядрышка. Структура ядрышек в гипертрофированных двуядерных клетках имеет свои особенности. Двуядерные гепатоциты с близко расположенными ядрами приблизительно одинаковой величины, давящими друг на друга, содержат ядрышки различной структуры, отличающиеся по величине в 2-3 раза. Крупное ядрышко может достигать 9 мкм $^{3}$ и имеет типичный ретикулярный тип строения. Ядрышко во втором ядре имеет переходный тип строения от компактного к ретикулярному. Это свидетельствует о разной функциональной нагрузке ядер в двуядерном гепатоците. Второе ядро можно рассматривать как «дополнительное», обеспечивающее повышенную синтетическую активность гипертрофированного гепатоцита (рисунки 7, 8). Важным показателем морфофункциональной активности клетки является ядрышко ядерное отношение (Яко/Я), которое рассчитывали делением объема ядрышка на объем ядра. Этот показатель колеблется более чем в десять раз $(0,01$ до 0,13). Низкое Яко/Я-отношение наблюдается в гепатоцитах с небольшим ядром, что отражает низкую синтетическую активность этих клеток.

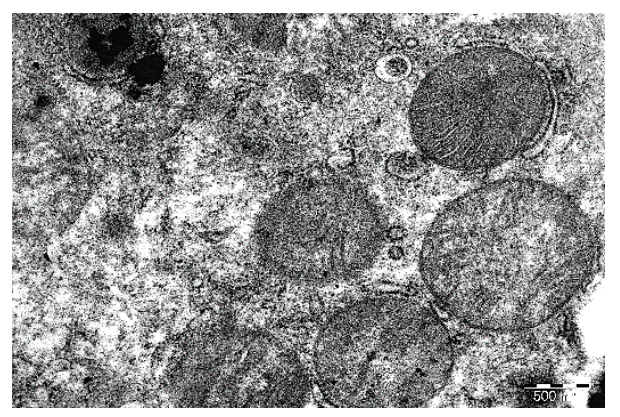

Рисунок 2

Митохондрии с хорошо видимыми кристами в гепатоцитах. Ув. 30000

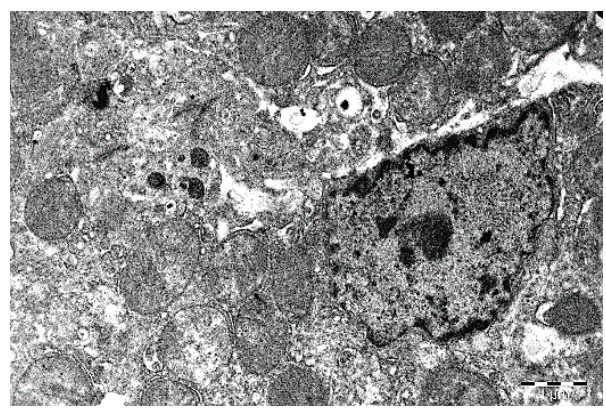

Рисунок 4

Билиарный полюс гепатоцита, пигменты в лизосомах. Ув. 8000 


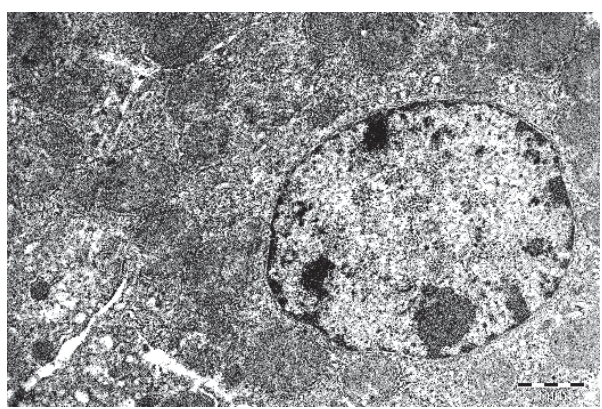

Рисунок 5

«Темный» гепатоцит. Интерхроматиновые гранулы в ядре. Ув. 10000

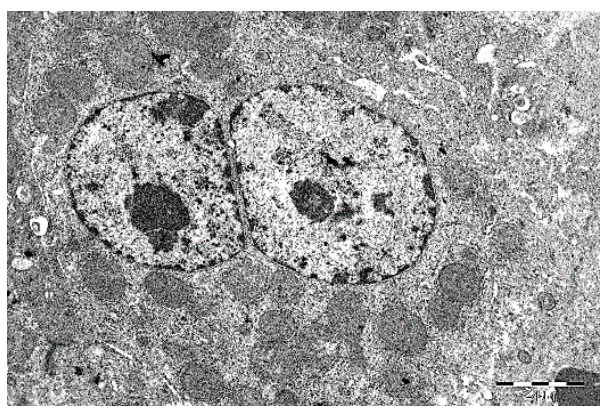

Рисунок 7

Двуядерный гепатоцит. Ядра с ядрышками, митохондрии, ЗЦС. Ув. 10000

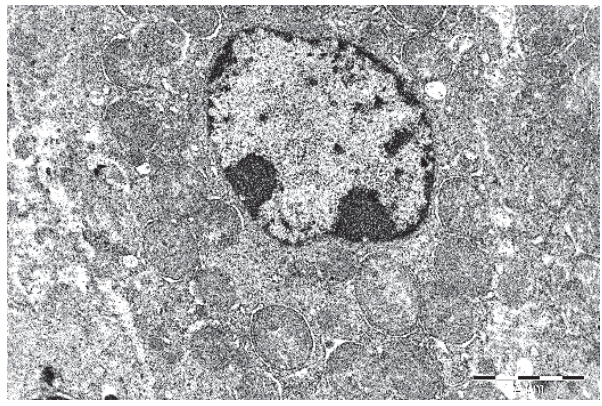

Рисунок 9

«Темный» гепатоцит. Ядро с интерхомати-новыми гранулами Ув. 10000

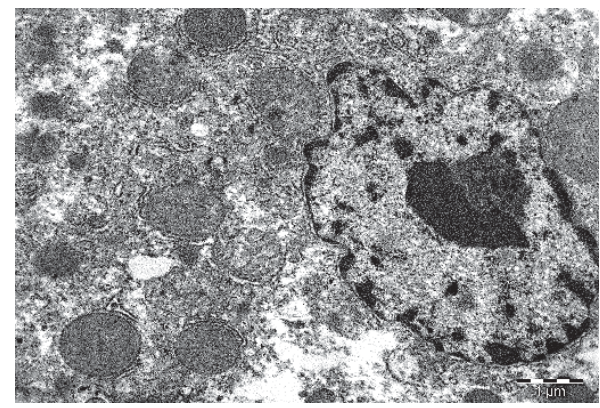

Рисунок 11

«Светлый» гепатоцит. Ядрышко со «спутником». Ув. 10000

Средняя величина отношения наблюдается как в мелких, так средних и крупных гепатоцитах, что свидетельствует о функциональной ге-

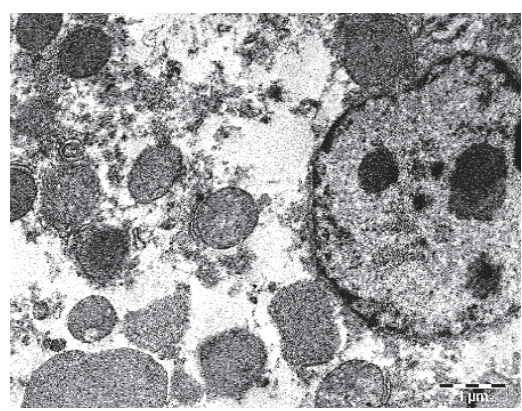

Рисунок 6

«Светлый» гепатоцит. Ядрышко, митохондрии, ЗЦС, ГЦС, лизосомы. Ув. 10000

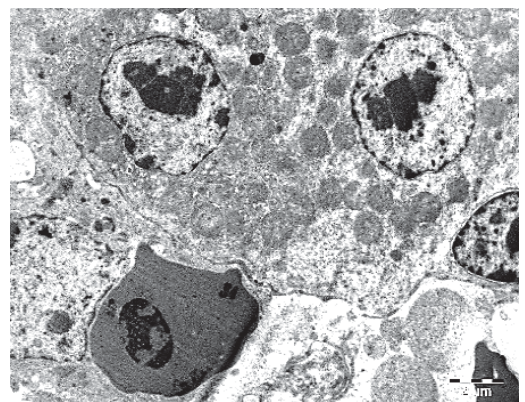

Рисунок 8

Двуядерный гепатоцит, звездчатый макрофаг, эритроцит, синусоид. Ув. 8000

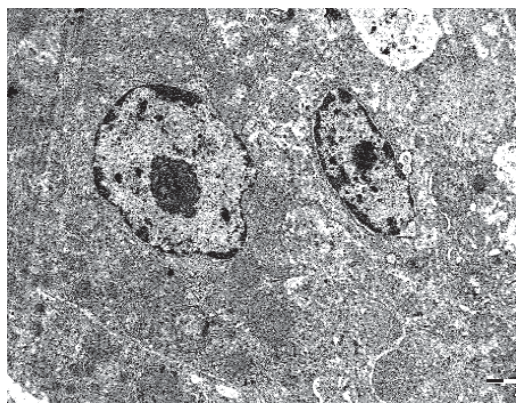

Рисунок 10

«Темный» гепатоцит с фибриллярными центрами в ядрышках. Ув. 10000

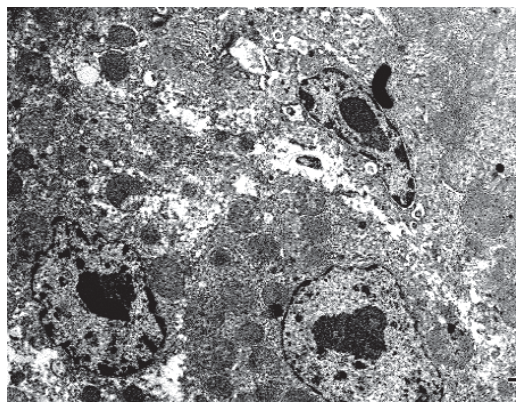

Рисунок 12

Гепатоциты, звездчатый макрофаг, синусоид.

Ув. 5000

терогенности гепатоцитов. Высокое Яко/Я-отношение наблюдается в двуядерных гипертрофированных гепатоцитах. Этот показатель поз- 
воляет интегрировать величины объема ядра и ядрышка и оценивать функциональную активность клетки.

Гепатоциты - это функционально активные клетки, выполняющие более пятисот функций, поэтому ядра этих клеток светлые и содержат мало периферического хроматина, формирующего вытянутые уплощенные тяжи, между которыми располагаются внутриядерные канальцы. Имеется также околоядрышковый хроматин. Кроме того, в большинстве ядер встречаются перихроматиновые гранулы. Периферический хроматин по ходу внутренней ядерной мембраны образует тяжи. Они тонкие, в виде небольших овальных возвышений, крупных возвышений, вытянутых к центру ядра островков или крупных конгломератов. В крупных ядрах (рисунки 8,11 ) периферический хроматин имеет вид узких полосок с большим количеством близко расположенных внутриядерных канальцев. В более мелких ядрах (рисунки 4, 6, 10) периферический хроматин представлен более крупными гранулами или даже конгломератами с редко расположенными внутриядерными канальцами. Хроматиновые островки в нуклеоплазме гепатоцитов располагаются на значительных расстояниях. Они преимущественно небольшой величины, осмиофильные. Кроме того, встречаются формы островков, имеющих гранулярную структуру. В крупных ядрах островков мало, а в более мелких их заметно больше и они более крупные и осмиофильные. Перихроматиновые гранулы мелкие и окружены просветленным ободком. Между гранулами и перихроматинованными фибриллами существует структурная связь. При увеличении более чем в 30 тысяч раз внутри гранул можно видеть тонкие извитые фибриллы [3]. Располагаются они ближе к центру ядра, только на периферии конденсированного хроматина, в диффузном хроматине их нет. Ин- терхроматиновые гранулы - это третий тип структур, содержащих РНК (наряду с перихроматиновыми фибриллами и гранулами). У перепелов они группируются в форме крупных скоплений между участками хроматина в виде «россыпи» (рисунки 5, 9). У водоплавающих птиц они имеют аналогичную структуру $[1,2]$. У животных эти гранулы не одинаковы по величине, переплетены с тонкими фибриллами и образуют четкообразные или сетчатые фигуры. Совершенно не ясно их функциональное значение [3]. Ядерная оболочка гепатоцитов имеет типичное строение и состоит из двух мембран, внешней и внутренней, между которыми располагается перинуклеарное пространство. Ядерная оболочка имеет характерную особенность, отличающую ее от других двухмембранных структур клетки (митохондрии и пластиды). Это наличие особых ядерных пор, которые образуются за счет многочисленных зон слияния двух ядерных мембран и представляют собой как бы округлые, сквозные перфорации всей ядерной оболочки.

Выводы. Ультраструктура гепатоцитов перепелов свидетельствует о высокой синтетической активности данных клеток, выполняющих в организме этих быстро растущих птиц более пятисот функций. Кариоцитометрия гепатоцитов позволяет выявить скрытые морфофункциональные особенности ультраструктуры клеток, которые при обычном качественном описании электроннограмм не выявляются. Кариоцитометрия гепатоцитов перепелов свидетельствует о ярко выраженной структурно-функциональной гетерогенности гепатоцитов. Электронномикроскопическое исследование с использованием кариоцитометрических методов является высокоинформативным методом оценки морфофункционального состояния органа, и его необходимо использовать при оценке влияния на организм фармакологических препаратов.

\section{Библиографический список}

1. Губайдуллин, А.С. Ультраструктурная характеристика печени гусей при использовании гепатопротектора «Диронакс» [Текст] / А.С. Губайдуллин, Е.Н. Сковородин, И.Р. Кильметова // Актуальные проблемы современной ветеринарной науки и практики: материалы международной научно-практической конференции, посвященной 70-летию Краснодарского научноисследовательского ветеринарного института (июнь 2016 г.). Краснодар, 2016. С. 19-21.

2. Давлетова, В.Д. Количественная цитометрия печени мускусных уток [Текст] / В.Д. Давлетова // Инновационному развитию аг- ропромышленного комплекса - научное обеспечение. Материалы международной научнопрактической конференции в рамках XXII Международной специализированной выставки «Агрокомплекс-2012». Уфа, 2012. С. 234-236.

3. Ченцов, Ю.С. Введение в клеточную биологию [Текст] / Ю.С. Ченцов. М., 2004. 495 с.

4. Serov V.V., Lapish K. Morphological diagnosis of liver diseases. Moscow, 1989. 336 p.

5. О ветеринарии [Текст]: Закон РФ.

6. Жестокое обращение с животными [Текст]: статья 245 // Уголовный кодекс Российской Федерации. 
7. О мерах по дальнейшему совершенствованию организационных форм работы с использованием экспериментальных животных [Текст]: приказ министерства здравоохранения СССР № 755 от 12 августа 1977.
8. Council of Europe - ETS no. 125 - European Convention for the Protection of Pet Animals.

\section{Сведения об авторах}

1. Бронникова Гузель Замилевна, аспирант кафедры морфологии, патологии, фармации и незаразных болезней, ФГБОУ ВО Башкирский ГАУ, 450001, Республика Башкортостан, г. Уфа, ул. 50-летия Октября, 34, тел.: (347) 228-28-77, e-mail: skovorodinen@mail.ru.

2. Сковородин Евгений Николаевич, доктор ветеринарных наук, профессор, зав. кафедрой морфологии, патологии, фармации и незаразных болезней, ФГБОУ ВО Башкирский ГАУ, 450001, Республика Башкортостан, г. Уфа, ул. 50-летия Октября, 34, тел.: (347) 228-28-77, e-mail: skovorodinen@mail.ru.

Изучена функциональная морфология гепатоцитов перепелов. Для этого проведено электронно-микроскопическое исследование печени перепелов. Количественно оценили структуру ядра и ядрышка с помощью объективных методов кариоцитометрии. Установили, что гепатоциты перепелов характеризуются высокой синтетической активностью. Кариоцитометрия гепатоцитов позволяет выявить скрытые морфофункциональные особенности ультраструктуры клеток, которые при обычном качественном описании электроннограмм не выявляются. Кариоцитометрия гепатоцитов перепелов свидетельствует о ярко выраженной структурнофункциональной гетерогенности гепатоцитов. Электронно-микроскопическое исследование с использованием кариоцитометрических методов является высокоинформативным методом оценки морфофункционального состояния органа, и его необходимо использовать при оценке влияния на организм фармакологических препаратов.

G. Bronnikova, E. Skovorodin

\section{ULTRASTRUCTURE AND HEPATOCYTE KARYOCYTOMETRY OF QUAILS}

Key words: quails; liver; hepatocytes; ultrastructure; cell organelles; hepatocyte nuclei; cell nucleoli.

\section{Authors' personal details}

1. Bronnikova Guzel, Post-graduate student the Morphology, pathology, pharmacy and noncontagious diseases department, Federal State Budgetary Educational Institution of Higher Education «Bashkir State Agrarian University», Ufa, 50-letiia Octiabria St., 34, phone: (347) 228-28-77, e-mail: skovorodinen@mail.ru.

2. Skovorodin Evgeny, Doctor of veterinary sciences, professor, head of the Morphology, pathology, pharmacy and noncontagious diseases department, Federal State Budgetary Educational Institution of Higher Education «Bashkir State Agrarian University», Ufa, 50-letiia Octiabria St., 34, phone: (347) 228-28-77, e-mail: skovorodinen@mail.ru.

The paper studies the functional morphology of quail hepatocytes. To conduct the research there was an electron-microscopic examination of quail liver. The structure of the nucleus and nucleolus were quantitatively assessed using objective methods of karyocytometry. Quail hepatocytes are found to have high synthetic activity. Hepatocyte karyocytometry enables to reveal hidden morphological characteristics of the cell ultrastructure being hardly detected under normal qualitative description of electron-diffraction photos. Quail hepatocyte karyocytometry indicates a pronounced structural and functional heterogeneity of hepatocytes. Therefore, electron-microscopic examination using karyocytometric methods is a highly informative method for assessing the morphological and functional state of the body and it should be used in assessing the impact of pharmacological agents on the body.

(C) Бронникова Г.3., Сковородин Е.Н. 
УДК 636.082.23

DOI: $10.31563 / 1684-7628-2019-51-3-42-47$

Е.В. Егорашина, Р.В. Тамарова

\section{ИСПОЛЬЗОВАНИЕ МАРКЕРНОЙ СЕЛЕКЦИИ В ПЛЕМЕННОЙ РАБОТЕ СО СТАДОМ МОЛОЧНОГО СКОТА РАЗНЫХ ПОРОД}

Ключевые слова: маркерная селекция; полиморфизм; белковомолочность; генотипирование; каппа-казеин; бета-лактоглобулин; айрширская порода; голитинская порода; голштино-ярославские помеси.

Введение. В Государственной программе развития сельского хозяйства и регулирования рынков сельскохозяйственной продукции, сырья и продовольствия на 2013-2020 годы предусматривается к 2020 году увеличение производства молока до 38,2 млн т (рост к 2010 году $19,9 \%$ ), скота и птицы на убой - до 14,07 млн т (рост 33,3 \%) Это позволит обеспечить достижение намеченных показателей Продовольственной доктрины по молоку и молочным продуктам на 90,2 \%, мясу и мясопродуктам - на 88,3\% [1, 2]. Но пока еще импортозависимость по основным продуктам в РФ остается значительной [3, 4]. Для решения проблемы необходимо более эффективно использовать современные методы зоотехнической науки, позволяющие в ускоренные сроки не только увеличить количество получаемой от животных продукции, но и улучшить ее качество. В молочном скотоводстве целесообразно внедрять методы ДНК-диагностики и маркерной селекции, широко применяемые в селекционных программах стран Европы и Америки. Актуальны эти задачи и для нашей страны $[5,6]$. Исследованиями зарубежных и отечественных ученых установлено, что надежными генетическими маркерами белковомолочности коров являются генотипы по каппа-казеину и бета-лактоглобулину [7-14].

Цель исследований - изучение полиморфизма молочных белков, сочетаний генотипов во взаимосвязи с молочной продуктивностью и породной принадлежностью коров. Эти исследования проводились с 2013 года в племзаводе по айрширской породе и племрепродукторе по голштинской - ЗАО «Агрофирма «Пахма» Ярославской области, где разводят также голштиноярославских помесей с кровностью по голштинам от 50 до $94 \%$, условно называемых «улучшенные генотипы».

Материалы и методы исследований. Общее поголовье коров в хозяйстве составляет
1100 голов, удельный вес пород: айрширской $40,0 \%$, голштинской $-36,4 \%$, голштино-ярославских помесей $-23,6 \%$. Средняя продуктивность по стаду, по данным бонитировок ОАО «Ярославское» по племенной работе, составляла за 305 дней лактации - 8045 кг молока, 4,35 \% жира, 3,17 \% белка [15]. Кормление коров проводят по детализированным нормам, концентрированные корма составляют в среднем $43 \%$. Система содержания - круглогодовая стойловопривязная, доение - в молокопровод фирмы ДеЛаваль, контрольные дойки 2 раза в месяц. Бонитировку коров ведут с использованием компьютерной программы «Селэкс». Имеется свой цех по переработке молока с изготовлением молочных продуктов - сметаны, творога, творожной массы и других. Оценка генотипов коров разной породности в единых средовых условиях являлась предпосылкой для получения наиболее достоверных результатов исследований. Подбор коров в группы для исследований осуществляли по методу сбалансированных групп-аналогов по возрасту в отелах (не менее 3 -х отелов), живой массе, с хорошей молочной продуктивностью, представляющих интерес для дальнейшей селекции. Для оценки животных использовали карточки племенных коров формы 2-МОЛ, каталоги быков-производителей, данные бонитировок ОАО «Ярославское» по племенной работе (2013-2017 годы). В выборку вошли 99 коров, в том числе 36 - айрширской породы, 33 голштинской и 30 - голштино-ярославских помесей с кровностью по голштину в среднем $84,2 \%$.

Методы исследований - общезоотехнические и популяционно-генетические с биометрической обработкой количественных показателей и расчетом достоверности разности при трех уровнях вероятности. Образцы крови для исследований генотипов по каппа-казеину и бета-лактоглобулину отбирали в соответствии с требованиями ветеринарного законодательства и по об- 
щепринятой методике. ДНК-тестирование проводили в лаборатории ДНК-технологий ФГБНУ ВНИИплем методом ПЦР-ПДРФ [6]. По результатам тестирования рассчитаны частоты встречаемости генотипов $\mathrm{AA}, \mathrm{AB}$ и ВB каппа-казеина и бета-лактоглобулина, а также аллельных вариантов А и В этих белков молока [16]. Состояние генного равновесия оценивали по закону ХардиВайнберга [16].

Результаты исследований. Данные оценки подконтрольных коров по основным показателям молочной продуктивности с учетом породности и в разрезе трех лактаций приведены в таблице 1 .

Таблица 1 Основные количественные показатели молочной продуктивности с учетом породности и в разрезе трех лактаций

\begin{tabular}{|c|c|c|c|c|c|c|c|}
\hline $\begin{array}{c}\text { Средний показатель } \\
\text { удоя за } 305 \text { дней } \\
\text { лактации } \\
\end{array}$ & $\begin{array}{c}\text { Кол-во } \\
\text { коров } \\
\text { (n) } \\
\end{array}$ & МДЖ, \% & МДБ, \% & МЖ, кг & МБ, кг & МБ + МЖ, кг & $\begin{array}{c}\text { Средняя } \\
\text { живая масса, } \\
\text { кг } \\
\end{array}$ \\
\hline \multicolumn{8}{|c|}{ Айрширская порода } \\
\hline \multicolumn{8}{|c|}{ по 1 отелу } \\
\hline $5985,11 \pm 139,50$ & 36 & $4,26 \pm 0,05$ & $3,17 \pm 0,03^{* * *}$ & $254,41 \pm 5,87$ & $190,05 \pm 4,96$ & $444,47 \pm 10,58$ & $509,44 \pm 3,04$ \\
\hline \multicolumn{8}{|c|}{ по 2 отелу } \\
\hline $6934,08 \pm 306,02$ & 24 & $4,19 \pm 0,05$ & $3,28 \pm 0,04$ & $291,05 \pm 13,67$ & $226,95 \pm 10,14$ & $518,00 \pm 23,59$ & $533,17 \pm 1,82$ \\
\hline \multicolumn{8}{|c|}{ по 3 отелу и старше } \\
\hline $8044,19 \pm 259,64$ & 16 & $4,31 \pm 0,09$ & $3,31 \pm 0,04$ & $347,43 \pm 14,16$ & $266,02 \pm 8,61$ & $613,45 \pm 22,17$ & $564,63 \pm 4,85$ \\
\hline \multicolumn{8}{|c|}{ Голштинская порода } \\
\hline \multicolumn{8}{|c|}{ по 1 отелу } \\
\hline $6254,15 \pm 157,82$ & 33 & $4,22 \pm 0,06$ & $3,00 \pm 0,03^{* * *}$ & $263,04 \pm 6,23$ & $187,59 \pm 5,13$ & $450,63 \pm 10,97$ & $533,15 \pm 5,48$ \\
\hline \multicolumn{8}{|c|}{ по 2 отелу } \\
\hline $7681,94 \pm 255,64$ & 33 & $4,02 \pm 0,07$ & $3,23 \pm 0,03$ & $308,69 \pm 11,97$ & $248,01 \pm 8,41$ & $556,70 \pm 19,67$ & $590,18 \pm 7,42$ \\
\hline \multicolumn{8}{|c|}{ по 3 отелу и старше } \\
\hline $10045,63 \pm 181,58$ & 30 & $4,58 \pm 0,06$ & $3,24 \pm 0,03$ & $459,83 \pm 9,62$ & $325,13 \pm 5,84$ & $784,96 \pm 14,80$ & $606,53 \pm 6,22$ \\
\hline \multicolumn{8}{|c|}{ Голштино-ярославские помеси } \\
\hline \multicolumn{8}{|c|}{ по 1 отелу } \\
\hline $6025,73 \pm 180,47$ & 30 & $4,13 \pm 0,05$ & $3,19 \pm 0,03 * * *$ & $248,09 \pm 7,30$ & $191,88 \pm 5,60$ & $439,98 \pm 12,70$ & $523,80 \pm 6,64$ \\
\hline \multicolumn{8}{|c|}{ по 2 отелу } \\
\hline $7347,17 \pm 212,60$ & 30 & $4,06 \pm 0,05$ & $3,26 \pm 0,04$ & $298,27 \pm 10,00$ & $238,61 \pm 6,61$ & $536,89 \pm 16,08$ & $560,73 \pm 5,91$ \\
\hline \multicolumn{8}{|c|}{ по 3 отелу и старше } \\
\hline $8447,61 \pm 239,33$ & 23 & $4,08 \pm 0,06$ & $3,21 \pm 0,04$ & $343,63 \pm 10,43$ & $270,74 \pm 7,64$ & $614,36 \pm 17,62$ & $617,13 \pm 8,75$ \\
\hline
\end{tabular}

Все коровы имеют высокий уровень молочной продуктивности и хорошо раздаиваются (коэффициент раздоя для коров айрширской породы от первой лактации ко второй $-1,16$, от третьей лактации к первой - 1,3 ; для голштинской породы соответственно 1,23 и 1,61 ; голштино-ярославских помесей $-1,22$ и 1,40). Рекомендуемые средние зоотехнические нормы соотношения удоев 1 и 2 лактации -1,2; 1-3 лактации - 1,3 (раздой 20-30 \%). Наибольший раздой от первой до третьей лактации выявлен у коров голштинской породы и голштино-ярославских помесей, что характерно для голштинов. По удою и МДЖ разность статистически не достоверна, по содержанию белка в молоке разность между коровами айрширской, голштинской пород и голштино-ярославских помесей высоко достоверна $(\mathrm{P}>0,999)$. Показатели изменчивости признаков находятся в пределах статистических норм: по удою - от 13 до $21 \%$, по МДЖ - от 5,7 до 7,65 \%, по МДБ - от 4,2 до $5,5 \%$. О полиморфизме гена каппа-казеина коров разных пород можно судить по данным таблицы 2.

Из таблицы 2 видно, что из 36 подконтрольных коров айрширской породы генотип АA каппа-казеина имеют 86,0 \% (31 голова), генотип $\mathrm{AB}$ каппа-казеина - 14,0 \% (5 голов), при этом отсутствует генотип ВВ по каппа-казеину; частота аллеля А составила $0,93 \pm 0,030$, а аллеля $\mathrm{B}-0,07 \pm 0,030$. Статистический метод Харди Вайнберга и метод $\chi^{2}\left(\chi^{2}=0,20\right)$ для выявления отклонений эмпирического распределения частот генотипов каппа-казеина от теоретического показал, что в группе коров айрширской породы не имеется статистически достоверного сдвига генетического равновесия ни по одному из трех генотипов по локусу гена каппа-казеина. Среди коров голштинской породы генотип АА по каппа-казеину обнаружили у 19 животных 
(58,0 \%), генотип АВ - у $11(33 \%)$ и наиболее желательный генотип ВВ по каппа-казеину - у 3 коров (9 \%). Частота аллея А составила $0,74 \pm$ 0,054 , а аллеля В $-0,26 \pm 0,054$. Не выявлено достоверной разности между частотами наблюдаемых и ожидаемых генотипов $\left(\chi^{2}=0,597\right)$, что указывает на генное равновесие у животных голштинской породы по локусу гена каппа-казеина.

У голштино-ярославских помесей генотип AА каппа-казеина имеют 77,0 \% (23 гол.), генотип $\mathrm{AB}$ каппа-казеина - 23,0 \% (7 гол.), генотип BB по каппа-казеину отсутствует, частота аллеля А составила $0,88 \pm 0,042$, а аллеля В $0,12 \pm 0,042$. Статистическую достоверность выявленных генотипов у голштино-ярославских помесей выявить не удалось $\left(\chi^{2}=0,387\right)$, при этом прослеживается большой недостаток гете- розигот и гомозигот по аллелю В. Таким образом, в ЗАО Агрофирма «Пахма» у коров всех изучаемых нами пород достаточно высокая частота встречаемости аллеля А каппа-казеина $(0,74-0,93)$ и низкая - аллеля В $(0,07-0,12)$. Низкая частота встречаемости аллеля В у айрширской породы и голштино-ярославских помесей выразилась в очень высокой (58-86 \%) встречаемости в стадах коров носителей генотипа АA, довольно редкой встречаемости генотипа $\mathrm{AB}$ и низкой (0-9 \%) встречаемости генотипа ВB. Результаты ДНК-диагностики по гену каппа-казеина свидетельствуют о том, что практически отсутствует генетическое разнообразие в локусе гена каппа-казеина. Причиной такой ситуации является использование в селекционном процессе быков-производителей, не имеющих в своем геноме аллель В.

Таблица 2 Полиморфизм генов каппа-казеина подконтрольных коров айрширской, голштинской пород и голштино-ярославских помесей

\begin{tabular}{|c|c|c|c|c|c|c|c|c|c|c|c|c|}
\hline \multicolumn{10}{|c|}{ CSN3 } & \multirow{4}{*}{$\mathrm{He}$} & \multirow{4}{*}{ Ho } & \multirow{4}{*}{$\chi^{2}$} \\
\hline \multirow{3}{*}{$\mathrm{n}$} & \multicolumn{7}{|c|}{ Частота встречаемости генотипов } & \multirow{2}{*}{\multicolumn{2}{|c|}{ Частота встречаемости аллелей $\pm m_{A}\left(m_{B}\right)$}} & & & \\
\hline & \multirow{2}{*}{$\begin{array}{l}\text { распре- } \\
\text { деление }\end{array}$} & \multicolumn{2}{|c|}{ AA } & \multicolumn{2}{|c|}{$\mathrm{AB}$} & \multicolumn{2}{|c|}{ BB } & & & & & \\
\hline & & $\mathrm{n}$ & $\%$ & $\mathrm{n}$ & $\%$ & $\mathrm{n}$ & $\%$ & A & $\mathrm{B}$ & & & \\
\hline \multicolumn{13}{|c|}{ Айрширская порода } \\
\hline \multirow{2}{*}{36} & $\mathrm{H}$ & 31 & 86 & 5 & 14 & - & - & \multirow{2}{*}{$0,93 \pm 0,030$} & \multirow{2}{*}{$0,07 \pm 0,030$} & \multirow{2}{*}{0,13} & \multirow{2}{*}{0,14} & \multirow{2}{*}{0,200} \\
\hline & $\mathrm{O}$ & 31 & 86,5 & 5 & 13 & 0 & 0,5 & & & & & \\
\hline \multicolumn{13}{|c|}{ Голштинская порода } \\
\hline \multirow{2}{*}{33} & $\mathrm{H}$ & 19 & 58 & 11 & 33 & 3 & 9 & \multirow{2}{*}{$0,74 \pm 0,054$} & \multirow{2}{*}{$0,26 \pm 0,054$} & \multirow{2}{*}{0,38} & \multirow{2}{*}{0,33} & \multirow{2}{*}{0,597} \\
\hline & $\mathrm{O}$ & 19 & 58 & 12 & 36 & 2 & 6 & & & & & \\
\hline \multicolumn{13}{|c|}{ Голштино-ярославские помеси } \\
\hline \multirow{2}{*}{30} & $\mathrm{H}$ & 23 & 77 & 7 & 23 & - & - & \multirow{2}{*}{$0,88 \pm 0,042$} & \multirow{2}{*}{$0,12 \pm 0,042$} & \multirow{2}{*}{0,21} & \multirow{2}{*}{0,23} & \multirow{2}{*}{0,385} \\
\hline & $\mathrm{O}$ & 23 & 78 & 6 & 21 & 1 & 1 & & & & & \\
\hline
\end{tabular}

Примечание: здесь и далее $\mathrm{H}$ - наблюдаемое распределение генотипов; О - ожидаемое распределение генотипов; $m_{A}\left(m_{B}\right)$ ошибка частот аллелей, Не - ожидаемая гетерозиготность, Но - наблюдаемая гетерозиготность, $\chi^{2}-$ критерий соответствия.

Полиморфизм гена бета-лактоглобулина подконтрольных коров можно проследить по данным таблицы 3. У 36 подконтрольных коров айрширской породы генотип АА бета-лактоглобулина имеют $11,0 \%$ (4 головы), генотип АВ бета-лактоглобулина - 47,0 \% (17 голов), а генотип ВВ бета-лактоглобулина - 42,0 \% (15 голов), при этом частота аллеля А составила $0,35 \pm$ 0,056 , а аллеля $\mathrm{B}-0,65 \pm 0,056$. Расчет по формулам Харди - Вайнберга и методу $\chi^{2}$ у группы коров айрширской породы показал, что нет достоверной разности между наблюдаемой и ожидаемой величинами частот генотипов $\mathrm{AA}, \mathrm{AB}$ и $\mathrm{BB}\left(\chi^{2}=0,037\right)$. У коров голштинской породы не был обнаружен генотип АА по бета-лактоглобулину, генотип $\mathrm{AB}$ выявили у 28 (85\%) коров и наиболее желательный генотип ВВ по бета-лактоглобулину - у 5 (15\%) животных. Частота встречаемости аллея А составила $0,42 \pm 0,061$, а аллеля В $-0,58 \pm 0,061$.

При исследовании коров голштинской породы была обнаружена достоверная разница между наблюдаемой и ожидаемой величинами частот генотипов в сторону преобладания генотипа АВ бета-лактоглобулина, что свидетельствует о нарушении генетического равновесия $\left(\chi^{2}=21,51 ; \mathrm{df}=1 ; \mathrm{p}<0,01\right)$, так как закон Харди - Вайнберга характерен для свободно размножающихся популяций; по-видимому, у животных голштинской породы стада ЗАО «Агрофирма «Пахма» проводится искусственный отбор по локусу гена бета-лактоглобулина. Среди голш- 
тино-ярославских помесей генотип АА бета-лактоглобулина имеют 10,0 \% (3 гол.), генотип АВ бета-лактоглобулина - 40,0 \% (12 гол.), генотип ВВ бета-лактоглобулина - 50,0 \% (15 гол.), частота встречаемости аллеля А составила $0,30 \pm$ 0,059 , а аллеля В - 0,70 $\pm 0,059$. Не выявлено достоверной разности между частотами наблюдаемых и ожидаемых генотипов $\left(\chi^{2}=0,037\right)$, что указывает на генное равновесие у голштино-ярославских помесей по локусу гена бета-лактоглобулина. В ЗАО «Агрофирма «Пахма» частота встречаемости аллеля В бета-лактоглобулина достаточно высокая $(0,58-0,70)$, а аллеля А находится на среднем уровне $(0,30-0,42)$.

В группе коров голштино-ярославских помесей встречаются все три варианта генотипа по бета-лактоглобулину, но наименьшая частота встречаемости у генотипа АА (10 \%). Соответственно, и частота встречаемости аллеля А ниже, чем аллеля В $(0,30$ против 0,70$)$. Таким об- разом, большинство исследованных нами животных несут в своем геноме желательный для молочной промышленности аллель В гена беталактоглобулина. Значения ожидаемой гетерозиготности по локусу гена бета-лактоглобулина у животных айрширской породы $(0,45 \%$ и $0,47 \%)$ и голштино-ярославских помесей $(0,42 \%$ и 0,49 \%) достоверно не различаются, а у животных голштинской породы получена достоверная разность между наблюдаемой $(0,85 \%)$ и ожидаемой $(0,49 \%)$ гетерозиготностью. Все быки ОАО «Ярославское» по племенной работе тестированы по генотипам каппа-казеина. Анализ по каталогам генотипов быков, использованных в подборе к стаду (быков-отцов), показал, что было мало производителей с В-аллельным вариантом каппа-казеина в генотипе. Основная селекция велась на удой, маркером которого является А-аллельный вариант и генотип АА по каппа-казеину [17].

Таблица 3 Полиморфизм генов бета-лактоглобулина подконтрольных коров айрширской, голштинской пород и голштино-ярославских помесей по анализируемым генам

\begin{tabular}{|c|c|c|c|c|c|c|c|c|c|c|c|c|}
\hline \multicolumn{10}{|c|}{ LGB } & \multirow{4}{*}{$\mathrm{He}$} & \multirow{4}{*}{ Ho } & \multirow{4}{*}{$\chi^{2}$} \\
\hline \multirow{3}{*}{$\mathrm{n}$} & \multicolumn{7}{|c|}{ Частота встречаемости генотипов } & \multirow{2}{*}{\multicolumn{2}{|c|}{ Частота встречаемости аллелей $\pm m_{A}\left(m_{B}\right)$}} & & & \\
\hline & \multirow{2}{*}{$\begin{array}{l}\text { распре- } \\
\text { деление }\end{array}$} & \multicolumn{2}{|c|}{ AA } & \multicolumn{2}{|c|}{$\mathrm{AB}$} & \multicolumn{2}{|c|}{ BB } & & & & & \\
\hline & & $\mathrm{n}$ & $\%$ & $\mathrm{n}$ & $\%$ & $\mathrm{n}$ & $\%$ & $\mathrm{~A}$ & B & & & \\
\hline \multicolumn{13}{|c|}{ Айрширская порода } \\
\hline \multirow{2}{*}{36} & $\mathrm{H}$ & 4 & 11 & 17 & 47 & 15 & 42 & \multirow{2}{*}{$0,35 \pm 0,056$} & \multirow{2}{*}{$0,65 \pm 0,056$} & \multirow{2}{*}{0,45} & \multirow{2}{*}{0,47} & \multirow{2}{*}{0,037} \\
\hline & $\mathrm{O}$ & 4 & 12 & 17 & 46 & 15 & 42 & & & & & \\
\hline \multicolumn{13}{|c|}{ Голштинская порода } \\
\hline \multirow{2}{*}{33} & $\mathrm{H}$ & - & - & 28 & 85 & 5 & 15 & \multirow{2}{*}{$0,42 \pm 0,061$} & \multirow{2}{*}{$0,58 \pm 0,061$} & \multirow{2}{*}{0,49} & \multirow{2}{*}{0,85} & \multirow{2}{*}{$21,51 * * *$} \\
\hline & $\mathrm{O}$ & 12 & 37 & 16 & 48 & 5 & 15 & & & & & \\
\hline \multicolumn{13}{|c|}{ Голштино-ярославские помеси } \\
\hline \multirow{2}{*}{30} & $\mathrm{H}$ & 3 & 10 & 12 & 40 & 15 & 50 & \multirow{2}{*}{$0,30 \pm 0,059$} & \multirow{2}{*}{$0,70 \pm 0,059$} & \multirow{2}{*}{0,42} & \multirow{2}{*}{0,40} & \multirow{2}{*}{0,037} \\
\hline & $\mathrm{O}$ & 3 & 9 & 12 & 41 & 15 & 50 & & & & & \\
\hline
\end{tabular}

Выводы. В единых средовых условиях при сбалансированном кормлении межпородные различия по удою и содержанию жира в молоке коров статистически не достоверны, а по содержанию белка в молоке разность высоко достоверна (P $\geq 0,999)$. Это обусловлено отсутствием целенаправленной селекции по белковомолочности, вследствие чего этот показатель у айрширских коров и голштино-ярославских помесей достоверно ниже породных возможностей (3,2-3,3 \% против 3,4-3,5\%). У коров всех исследованных пород в группах установлена высокая частота встречаемости аллеля А каппа-казеина $(0,74-0,93)$ и низкая - аллеля В $(0,07-0,12)$, особенно у коров айрширской породы ввиду отсутствия его у быков-отцов. По частоте встреча- емости аллельных вариантов и генотипов беталактоглобулина, наоборот, ситуация обратная: В-аллель бета-лактоглобулина в генотипах всех коров установлен с частотой $0,58-0,70$, А-аллель - на среднем уровне - 0,30-0,42. Такое распределение у коров генотипов бета-лактоглобулина (маркера хороших технологических качеств молока) желательно для выработки молочной продукции.

Предложение производству. Для повышения белковомолочности коров стада целесообразно больше использовать в подборе быковпроизводителей с В-аллельным вариантом по каппа-казеину и вести целенаправленную селекцию по этому признаку наряду с селекцией по удою. 


\section{Библиографический список}

1. Молочное скотоводство России [Текст]/ Под ред. Н.И. Стрекозова и Х.А. Амерханова. Москва, 2013. 616 с.

2. Развитие сельского хозяйства и регулирование рынков сельскохозяйственной продукции, сырья и продовольствия на 2013-2020 годы [Текст]: Государственная программа. Постановление Правительства Российской Федерации от 14 июля 2012 г. № 717. 2012. 80 с.

3. Социально-экономическое положение России - 2017. Статистическое обозрение [Электронный ресурс] / Федеральная служба государственной статистики. Режим доступа: http:// www.gks.ru/wps/wcm/connect/rosstat main/rosstat/ ru. Дата обращения: 06.12.2018 г.

4. О текущей ситуации в агропромышленном комплексе Российской Федерации [Электронный ресурс] / Министерство сельского хозяйства Российской Федерации. Режим доступа: http://old.mcx.ru/documents/document/show/15381. htm. Дата обращения 21.02.2018 г.

5. Калашникова, Л.А. Возможности использования ДНК маркеров продуктивных качеств животных в практической селекционной работе [Текст] / Л.А. Калашникова // Современные достижения и проблемы биотехнологии сельскохозяйственных животных. Дубровицы, 2003. C. 33-39.

6. Калашникова, Л.А. Рекомендации по геномной оценке крупного рогатого скота [Текст] / Л.А. Калашникова, Я.А. Хабибрахманова. Московская область: ФГБНУ ВНИИплем, 2015. $34 \mathrm{c}$.

7. Зиновьева, Н.А. Роль ДНК-маркеров признаков продуктивности сельскохозяйственных животных [Текст] / Н.А. Зиновьева, О.В. Костюнина, Е.А. Гладырь, А.Д. Банникова и др. // Зоотехния. 2010. № 1. С. 8-10.

8. Тамарова, Р.В. Экономическая эффективность производства молока коров с разными генотипами каппа-казеина [Текст] / Р.В. Тамарова, Л.А. Андриянова. Ярославль: Ярославская ГСХА, 2003. С. 14-16.

9. Тамарова, Р.В. Селекционные методы повышения белковомолочности коров с использованием генетических маркеров [Текст]: моно- графия / Р.В. Тамарова, Н.Г. Ярлыков, Ю.А. Корчагина. Ярославль: Ярославская ГСХА, 2014. $124 \mathrm{c}$.

10. Танана, Л.А. Использование ДНК-тестирования по гену CSN3 в селекции молочного крупного рогатого скота [Текст]: монография / Л.А. Танана и др. Гродно: ГГАУ, 2014. 193 с.

11. Хабибрахманова, Я.А. Генное разнообразие молочных пород крупного рогатого скота [Текст] / Я.А. Хабибрахманова, Л.А. Калашникова // Устойчивое развитие экономики: состояние, проблемы, перспективы. Сборник науч. тр. Минск: ПГУ, 2009. С. 48-49.

12. Ярлыков, Н.Г. Влияние генотипа каппаказеина на сыропригодность молока коров ярославской породы и михайловского типа [Текст]: монография / Н.Г. Ярлыков, Р.В. Тамарова. Ярославль: Ярославская ГСХА, 2014. 124 с.

13. Mohammadi Y., Aslaminejad A.A., Nassiri M.R., Koshkoieh A.E. Allelic polymorphism of $\mathrm{K}$-casein, $\beta$-Lactoglobulin and leptin genes and their association with milk production traits in Iranian Holstein cattle. J. of Cell and Molecular Research. 2013. 5 (2). P. 75-80.

14. Sitkowska B. Kowaliszyn B., Mroczkowski S. Comparison of daily milk yield and its chemical composition between cows from selected genetic groups of beta-lactoglobulin and kappa-casein genes. J. Cent. Eur. Agric. 2010. V. 11, №3. P. 317324.

15. Ежегодник по племенной работе в молочном скотоводстве в хозяйствах Российской Федерации [Текст]. М.: ВНИИплем МСХ РФ, Департамент животноводства и племенного дела, 2016.

16. Меркурьева, Е.К. Генетика с основами биометрии [Текст] / Е.К. Меркурьева, Г.Н. Шангин-Березовский. М.: Колос, 1983. 424 с.

17. Каталог быков-производителей молочных и молочно-мясных пород, оцененных по качеству потомства [Текст] / ОАО «Головной центр по воспроизводству сельскохозяйственных животных», ОАО «Московское по племенной работе», ОАО «Ярославское» по племенной работе, ФГНУ ВНИИплем]. Ярославль. М., 2009-2018.

\section{Сведения об авторах}

1. Егорашина Екатерина Валерьевна, аспирант, ФГБОУ ВО Ярославская ГСХА, 150042, Ярославская обл., г. Ярославль, Тутаевское шоссе, 58, тел.: (4852) 50-53-60, e-mail: egorashina@yarcx.ru. 
2. Тамарова Раиса Васильевна, доктор сельскохозяйственных наук, профессор, ФГБОУ ВО Ярославская ГСХА, 150042, Ярославская обл., г. Ярославль, Тутаевское шоссе, 58, тел.: (4852) 50-53-70, e-mail: r.tamarova@yarcx.ru.

В РФ сохраняется импортозависимость по основным продуктам питания. В Государственных программах ставится задача в короткие сроки увеличить не только количество выпускаемой продукции, но и ее качество, что возможно благодаря внедрению в молочное скотоводство ДНК-технологий. Надежными генетическими маркерами белковомолочности коров являются генотипы по каппа-казеину и бета-лактоглобулину. Нами изучен полиморфизм молочных белков, сочетание генотипов во взаимосвязи с молочной продуктивностью и породной принадлежностью коров айрширской, голштинской пород и голштино-ярославских помесей. Установлено, что в единых средовых условиях при сбалансированном кормлении межпородные разли- чия по удою и содержанию жира в молоке коров статистически не достоверны, а по содержанию белка в молоке разность высоко достоверна (P $\geq$ 0,999). У коров всех пород в группах установлена высокая частота встречаемости аллеля А каппа-казеина $(0,74-0,93)$ и низкая - аллеля В $(0,07-0,12)$, особенно у коров айрширской породы. В-аллель бета-лактоглобулина в генотипах всех коров встречался с частотой $0,58-0,70$, А-аллель - на среднем уровне - 0,30-0,42. Хозяйству для повышения белковомолочности коров стада целесообразно больше использовать в подборе быков-производителей с В-аллельным вариантом по каппа-казеину и вести целенаправленную селекцию по этому признаку наряду с удоем.

E. Egorashina, R. Tamarova

\section{USING A MARKER-BASED SELECTION IN BREEDING OF DAIRY CATTLE OF DIFFERENT BREEDS}

Key words: marker-based selection; polymorphism; protein milkability; genotyping; kappa casein; betalactoglobulin; Ayrshire breed; Holstein breed; Holstein-Yaroslavl cross breed.

\section{Authors' personal details}

1. Egorashina Ekaterina, Post-graduate, Federal State Budgetary Educational Institution of Higher Professional Education Yaroslavl State Agricultural Academy, Yaroslavl, Tutaevskoe highway, 58, phone: (4852) 50-53-60, e-mail: egorashina@yarcx.ru.

2. Tamarova Raisa, Doctor of agricultural sciences, professor, Federal State Budgetary Educational Institution of Higher Professional Education Yaroslavl State Agricultural Academy, Yaroslavl, Tutaevskoe highway, 58, phone: (4852) 50-53-70, e-mail: r.tamarova@yarcx.ru.

Dependence on imports of main food products remains unchanged in the Russian Federation. Government programms set goals to increase quantity as well as quality of manufactured products. It is possible due to the introduction of a DNA technology into dairy cattle breeding. Reliable genetic markers of a cow protein milk ability are kappa casein and beta-lactoglobulin. We have studied milk proteinpolymorphism, genotype combinations in interconnection with milk ability and breed for the Ayrshire, Holstein and Holstein-Yaroslavl cross breed cows. It was found that in the same conditions and with the balanced feeding differences in milk yield and quantity of fat in milk among breeds are statistically unreliable while in milk protein quantity the difference is highly reliable $\mathrm{D} \geq 0,999$. There is high occurrence frequency of A kappa casein allele $(0,74$ $0,93)$ and low of kappa casein allele B $(0,07-0,12)$, especially in case of the Ayrshire breed. B-allele of beta-lactoglobulin in the genotype of all cows is seen with the frequency of $0,58-0,70$, A-allele is average $(0,30-0,42)$. In order to increase the protein milk ability of the cows farms are to use more Ballele kappa-casein servicing bulls. Target breeding according to this characteristic as well as milk yield is also recommended.

(C) Егорашина Е.В., Тамарова Р.В. 
УДК 619:616.98:578.824.11

DOI: 10.31563/1684-7628-2019-51-3-48-52

Д.Н. Латфуллин, Р.М. Ахмадеев, Н.Р. Мифтахов, Х.Н. Макаев

\section{РЕЗУЛЬТАТЫ ИССЛЕДОВАНИЙ НАПРЯЖЕННОСТИ ИММУНИТЕТА КРУПНОГО РОГАТОГО СКОТА, ВАКЦИНИРОВАННОГО ПРОТИВ БЕШЕНСТВА, В РЕСПУБЛИКЕ ТАТАРСТАН И ПРИГРАНИЧНЫХ С НЕЙ РАЙОНАХ РЕСПУБЛИКИ БАШКОРТОСТАН}

\section{Ключевые слова: бещенство; вирус; эпизоотологический анализ; вакцинация; крупный рога- тый скот.}

Введение. Бешенство - острое инфекционное заболевание человека и животных, вызываемое вирусом и характеризующееся высокой летальностью $[3,7,8,12,13]$. Заболевание передается главным образом через укус больного или, очень редко, в результате попадания инфицированной слюны на поврежденную кожу или слизистую оболочку $[9,10,14]$. Мировой опыт показывает, что современные меры борьбы с бешенством позволяют взять его под контроль, а в ряде случаев полностью ликвидировать у наземных млекопитающих [15]. Проведение противоэпизоотических мероприятий должно основываться на изучении краевой эпизоотологии этого зооноза, своевременном выявлении возбудителя бешенства и изучении его биологических свойств $[1,2,4]$. Основной концепцией борьбы с этой болезнью является вакцинация животных [11]. Однако успех может быть достигнут только при использовании комплекса мер, включающих научно обоснованное планирование проведения вакцинации и мониторинга ее эффективности [5].

Цель исследований - оценка эпизоотической ситуации по бешенству на территории Республики Татарстан и объемов проведения противоэпизоотических мероприятий среди домашних, диких и сельскохозяйственных животных, исследование сывороток крови крупного рогатого скота по оценке эффективности вакцинопрофилактики бешенства.

Условия, материалы и методы. С целью анализа заболеваемости бешенством среди животных использовали отчетные данные Департамента ветеринарии Минсельхоза России, Россельхознадзора и Главного управления ветеринарии Кабинета Министров Республики Татарстан. Для обобщения информации по поголовью крупного рогатого скота использовали официальные данные Росстата. Исследования сывороток крови крупного рогатого скота по оценке эффективности вакцинопрофилактики бешенства проводили с использованием «Иммуноферментной тест-системы для определения уровня антител к вирусу бешенства в сыворотках крови животных, вакцинированных против бешенства методом непрямого иммуноферментного анализа, разработанным ФГБНУ «ФЦТРБ-ВНИВИ» и утвержденным в установленном порядке. В качестве положительной сыворотки использовали отраслевой стандартный образец антирабической сыворотки (референс-сыворотка) ВГНКИ с активностью $20 \mathrm{ME} / \mathrm{мл}$.

Результаты исследований. За последние годы бешенство среди животных было зарегистрировано во всех административных единицах Республики Татарстан. В период с 2010 по 2018 годы в республике заболело 1776 животных, в том числе 373 гол. - в 2009 г., 239 гол. - в 2010 г., 126 гол. - в 2011 г., 296 гол. - в 2012 г., 255 гол. - в 2013 г., 132 гол. - в 2014 г., 295 гол. - в 2015 г., 20 гол. - в 2016 г., 18 гол. - в 2017 г., 24 гол. - в 2018 г.

В среднем с 2009 по 2015 гг. диагноз был установлен в 245 случаях, с 2016 по 2018 гг. бешенство в среднем регистрировалось в 20 случаях. Заболеваемость животных снизилась в 12 раз. Данный показатель связан с увеличением охвата поголовья животных, подвергнутых вакцинации. Если в период с 2010 по 2014 год объемы вакцинации подвергались 230-280 тыс. гол./год крупного рогатого скота, то с 2015 года данный показатель увеличился до 500-800 тыс. гол./год. Показатели вакцинации домашних животных за те же периоды увеличились в 1,52 раза. В 2016 г. бешенство выявлено в 16 административных районах Республики Татарстан, в том числе 4 - в Сабинском, 2 - в Спасском и по 1 в Азнакаевском, Актанышском, Альметьевском, Арском, Балтасинском, Бугульминском, Заинском, Менделеевском, Мензелинском, Муслюмовском, Пестречинском, Сармановском, Тукаевском и Ютазинском районах, т. е. всего 20 случаев. Лисы составили 9 гол., кошки -6 гол., собаки - 3 гол., КРС - 1 гол., лось - 1 гол. 
В 2017 г. бешенство выявлено в 13 административных районах Республики Татарстан, в том числе по 2 - в Агрызском, Высокогорском, Елабужском, Сабинском и по 1 - в Апастовском, Атнинском, Арском, Балтасинском, Кайбицском, Кукморском, Мамадышском, Тукаевском и Тюлячинском районах, т. е. всего 18 случаев. Лисы составили 11 гол., кошки - 4 гол., собаки - 2 гол., КРС - 1 гол. В 2018 г. бешенство выявлено в 17 административных районах Республики Татарстан, в том числе по 3 - в Пестречинском и Сабинском, по 2 - в Муслюмовском, Лениногорском и Тукаевском, по 1 - в Алексеевском, Альметьевском, Апастовском, Буинском, Верхне-Услонском, Высокогорском, Заинском, Зеленодольском, Мензелинском, Рыбно-Слободском и Спасском районах, т. е. всего 24 случая.

Структура заболеваемости бешенством животных в Республике Татарстан в 2018 году выглядит следующим образом (гол.): 13 - лисы, 4 - кошки, 3 - собаки, 2 - енотовидные собаки, 1 - крупный рогатый скот.

Основным источником возбудителя бешенства в Республике Татарстан являются представители дикой фауны, при этом наибольшее количество выявленных случаев заболевания бешенством приходится на лисиц.

В Республике Башкортостан также сохраняется напряженная эпизоотическая ситуация по бешенству. Бешенство животных регистрируется на территории всех районов и даже в городах. В 2018 году было зарегистрировано 12 случаев бешенства среди животных на территории 12 населенных пунктов. Наибольшее количество выявленных случаев заболевания приходится на домашних собак и кошек. Из сельскохозяйственных животных бешенство установлено только у 1 гол. крупного рогатого скота. Вакцинация животных является одним из основных факторов сдерживания инфекции. Особое значение имеет проведение профилактических мероприятий против бешенства среди сельскохозяйственных животных. В связи с этим в лаборатории иммунологии ФГБНУ «ФЦТРБ-ВНИВИ» проводили исследования по оценке профилактики бешенства среди крупного рогатого скота из ряда районов Республики Татарстан и приграничных районах Республики Башкортостан.
В Республиках Татарстан и Башкортостан насчитывается свыше 1025 тыс. гол. и свыше 1028,5 тыс. гол. крупного рогатого скота соответственно. Пробы сывороток крови крупного рогатого скота в лабораторию иммунологии доставляли из Пестречинского, Кукморского, Высокогорского, Рыбно-Слободского, Сабинского, Чистопольского, Лениногорского, Альметьевского, Арского, Нурлатского, Муслюмовского, Апастовского, Азнакаевского, Мензелинского районов Республики Татарстан (всего 149 проб). Все пробы поступали в феврале - марте 2018 г.

Исследования сывороток крови крупного рогатого скота проводили методом ИФА согласно ГОСТ 26075-2013. В 2017 и 2018 гг. в Республике Татарстан было вакцинировано соответственно 802540 и 786964 гол. крупного рогатого скота. Применялась вакцина «Щелково$51 »$.

Пробы сывороток крови крупного рогатого скота из Республики Башкортостан доставляли из Туймазинского, Шаранского и Буздякского районов (всего 199 проб). Проведенными исследованиями сывороток крови крупного рогатого скота после вакцинации установили высокий уровень специфических антител к вирусу бешенства, составляющий от 1:50 - 1:400 в непрямом ИФА, что соответствует 0,5-4,0 МЕ/мЛ в реакции нейтрализации. Поголовье животных считается защищенным от возможного заражения вирусом бешенства, если доля животных, обладающих защитным титром, составляет не менее $70 \%$.

Выводы. Исследованиями, проведенными в лаборатории иммунологии ФГБНУ «ФЦТРБВНИВИ» установили, что в районах Республики Татарстан и приграничных районах Республики Башкортостан уровень защищенности поголовья крупного рогатого скота достаточно высокий. Данные лабораторных исследований подтверждаются низким процентом выявления больных бешенством сельскохозяйственных животных, в частности у крупного рогатого скота. Для выяснения более полной картины состояния защищенности крупного рогатого скота от возможного заболевания бешенством работы в данном направлении будут продолжены с охватом большего количества животных.

\section{Библиографический список}

1. Авилов, В.М. Необходим учет новых особенностей эпизоотологии бешенства [Текст] / В.М. Авилов, В.А. Седов, С.А. Коломыцев, В.А. Ведерников, П.Н. Пыталев, А.М. Гулюкин, Г.В. Хакин // Ветеринария. 1998. № 6. С. 3-6.
2. Апалькин, В.А. Бешенство животных в России. Особенности современной эпизоотической обстановки [Текст] / В.А. Апалькин, В.А. Ведерников, И.В. Балдина, Н.А. Яременко, А.М. Гулюкин, А.А. Харкевич, С.А. Коломыцев, 
А.А. Шабейкин // Ветеринария. 2004. № 12. C. 3-7.

3. Бурдов, Г.Н. Мониторинг бешенства животных на территории Удмуртской Республики [Текст] / Г.Н. Бурдов, Е.И. Марасинская, Н.А. Хисматуллина, С.Г. Явкин // Ветеринарный врач. 2014. № 3. С. 21-25.

4. Крюков, С.В. Борьба с бешенством в Кировской области. Особенности эпизоотического процесса [Текст] / С.В. Крюков, Н.В. Мельник, В.Н. Боровой, С.Г. Дресвянникова // Вопросы нормативно-правового регулирования в ветеринарии. 2011. № 2. С. 25-28.

5. Метлин, А.Е. Оральная вакцинация диких плотоядных животных против бешенства [Текст] / А.Е. Метлин, С.С. Рыбаков, В.В. Михалишин, Th. Muller // Ветеринария. 2009. № 8. C. $18-25$.

6. Мухин, А.Н. Длительность и напряженность антирабического иммунитета у кошек после вакцинации вакциной «Рабифел» [Текст] / А.Н. Мухин, С.А. Раев, М.А. Лосич, О.Н. Зайкова, О.В. Остапчук, И.В. Непоклонова, О.А. Верховский, Т.И. Алипер // Ветеринария и кормление. 2018. № 6. С. 37-39.

7. Недосеков, В.В. Сравнительная оценка методов лабораторной диагностики бешенства [Текст] / В.В. Недосеков // Ветеринарная патология. 2002. № 1. С. 41-47.

8. Профилактика и борьба с болезнями, общими для человека и животных. Бешенство [Текст]: санитарные правила СП 3.1.096-96. Ветеринарные правила ВП 13.3.1103-96. М., 1996. $34 \mathrm{c}$.

9. Сидорчук, А.А. Инфекционные болезни животных [Текст] / А.А. Сидорчук, Н.А. Масимов, В.Л. Крупальник и др. М.: ИНФРА-М, 2017. $954 \mathrm{c}$.
10. Сокова, Л.С. Проблемы профилактики бешенства безнадзорных собак и кошек [Текст] / Л.С. Сокова, В.Н. Сазонкин, Н.М. Пухова // Актуальные вопросы ветеринарной биологии. 2015. № 3. C. 33-37.

11. Таршис, М.Г. Болезни животных, опасные для человека [Текст] / М.Г. Таршис, Б.Л. Черкасский. М.: Колос, 1997. 298 с.

12. Фазылов, В.Х. Диагностика бешенства (клинический случай) [Текст] / В.Х. Фазылов, Г.Х. Муртазина, Ю.Р. Урманчеева, Р.И. Мингажева // Практическая медицина. 2014. № 7 (83). C. $127-129$.

13. Хисматуллина, Н.А. Эпизоотолого-эпидемиологический надзор и прогноз бешенства в Республике Татарстан [Текст] / Н.А. Хисматуллина, Р.Х. Юсупов, А.З. Равилов, Т.А. Савицкая, М.М. Каримов, А.В. Иванов, А.Н. Чернов // Ветеринарные и медицинские аспекты зооантропонозов: труды Междунар. науч.-практ. конф., посвящ. 45-летию ВНИИВВиМ. Ч. 1, г. Покров, 24-26 сент. 2003 г. Покров, 2003. С. 107-114.

14. Хрипунов, Е.М. Бешенство диких плотоядных животных [Текст] / E.M. Хрипунов, С.Д. Евсеева, М.Г. Окрошидзе, И.А. Сливко, В.М. Котляров, В.И. Жестерев, Н.В. Дмитриенко, А.В. Книзе, А.Н. Егоров, В.И. Фертиков, С.А. Пархомцев // Ветеринария. 2002. № 2. С. 6-9.

15. Чернов, А.Н. Динамика распространения бешенства среди животных на территории Республики Татарстан на фоне всей территории Российской Федерации [Текст] / А.Н. Чернов, Д.Н. Латфуллин, Р.М. Ахмадеев, Ш.М. Насыров, И.И. Самерханов, Н.Р. Мифтахов // Ветеринария Кубани. 2019. № 2. С. 6-9.

\section{Сведения об авторах}

1. Латфуллин Дамир Наилевич, кандидат ветеринарных наук, и. о. зав. лабораторией иммунологии, ФГБНУ «Федеральный центр токсикологической, радиационной и биологической безопасности», 420075, г. Казань, Научный городок-2, e-mail: domrich@mail.ru.

2. Ахмадеев Рафаил Мазитович, кандидат ветеринарных наук, ведущий научный сотрудник, ФГБНУ «Федеральный центр токсикологической, радиационной и биологической безопасности», 420075, г. Казань, Научный городок-2, e-mail: ahm_rafail@mail.ru.

3. Мифтахов Нияз Рафисович, кандидат биологических наук, старший научный сотрудник лаборатории иммунологии ФГБНУ «Федеральный центр токсикологической, радиационной и биологической безопасности», 420075, г. Казань, Научный городок-2, e-mail: vnivi@mail.ru.

4. Макаев Харис Нуртдинович, доктор ветеринарных наук, профессор, начальник отдела биологической безопасности, ФГБНУ «ФЦТРБ-ВНИВИ», 420075, г. Казань, Научный городок-2, тел.: (843) 239-53-44, e-mail: kharis.makaev@mail.ru.

Борьба с бешенством предусматривает профилактическую иммунизацию сельскохозяй- ственных и домашних животных, отлов безнадзорных собак и кошек, оральную вакцинацию 
диких животных, а также мероприятия по регулированию численности дикой фауны. Жвачные животные являются тупиковым направлением развития эпизоотии бешенства. Наличие фактов заболевания жвачных животных бешенством является результатом развития эпизоотического процесса в популяции диких животных в данной местности, даже в том случае, если эпизоотия среди диких животных не регистрируется. Снижение численности поголовья крупного рогатого скота за последние годы на европейской части России в более чем в два раза повлекло снижение случаев выявления бешенства у этих животных. Вакцинация формирует в поголовье животных прослойку, препятствующую дальнейшему распространению инфекции, и способствует дальнейшему снижению заболеваемости. В статье представлены данные эпизоотической ситуации по бешенству на территории Татарстана в 2018 г., объемы проведения противоэпи- зоотических мероприятий среди домашних, диких и сельскохозяйственных животных, изложены результаты собственных лабораторных исследований проб сывороток крови крупного рогатого скота, вакцинированного против бешенства в ряде районов Республики Татарстан и приграничных районах Республики Башкортостан. Полученные данные свидетельствуют, что мероприятия по профилактике бешенства в указанных субъектах проводятся достаточно эффективно. Заболеваемость сельскохозяйственных животных бешенством сведена к минимуму за счет большого охвата поголовья животных, подвергнутых вакцинации, а также проведения профилактических противоэпизоотических мероприятий в дикой фауне. Для обеспечения более надежной защиты поголовья крупного рогатого скота в ряде районов необходимо проведение ревакцинации крупного рогатого скота.

D. Latfullin, R. Akhmadeev, N. Miftahov, Kh. Makaev

\section{STUDY RESULTS OF IMMUNE RESPONSE INTENSITY IN CATTLE VACCINATED AGAINST RABIES IN THE REPUBLIC OF TATARSTAN AND BORDER AREAS OF THE REPUBLIC OF BASHKORTOSTAN}

Key words: rabies; virus; epizootological analysis; vaccination; cattle.

\section{Authors' personal details}

1. Latfullin Damir, Candidate of Veterinary Sciences, acting head of the laboratory of immunology, Federal State Budgetary Research Institution «Federal center for toxicological, radiation and biological safety»,420075, Kazan, Scientific town-2, e-mail: domrich@mail.ru.

2. Akhmadeev Rafail, Candidate of Veterinary Sciences, leading researcher of laboratory of immunology, Federal State Budgetary Research Institution «Federal center for toxicological, radiation and biological safety», 420075, Kazan, Scientific town-2, e-mail: ahm_rafail@mail.ru.

3. Miftahov Niyaz, Candidate of Biological Sciences, researcher of the laboratory of immunology FSBSO «Federal center for toxicological, radiation and biological safety», 420075, Kazan, Scientific town-2, e-mail: vnivi@mail.ru.

4. Makaev Kharis, Doctor of Veterinary Sciences, Professor, head of Biological Safety Department, Federal State Budgetary Research Institution «Federal center for toxicological, radiation and biological safety, 420075, Kazan, Scientific town-2, phone: (843) 239-53-44, e-mail: kharis.makaev@mail.ru.

Rabies control programs include preventive immunization of farm and domestic animals, catching stray dogs and cats, oral vaccination of wild animals, and measures to control the number of the wildlife. Rabies in ruminants is a deadlock in the rabies epizootic situation. Rabies in ruminant animals is the result of the epizootic process in wild animals of the area, even if the process is not recorded. The more than doubled decrease in the number of cattle the European part of Russia saw in recent years resulted in a decrease in cases of rabies in these animals. Vaccination forms the animal group that prevents the further spread of infection, and further reduces morbidity. The paper presents the data on the rabies epizootic situation on the territory of Tatarstan in 2018, preventive measures against the epizootic situation among domestic, wild and farm animals. Also, it presents laboratory results of blood 
serum samples in the cattle vaccinated against rabies in some areas of Tatarstan and border areas of Bashkortostan. The study results indicate that both regions take effective measures against rabies. The incidence of rabies in farm animals is minimized due to a large number of vaccinated animals, and preventive measures taken against rabies among wild animals. Revaccination of cattle is needed in a number of areas to ensure better protection of animals.

\section{(с Латфуллин Д.Н., Ахмадеев Р.М., Мифтахов Н.Р., Макаев Х.Н.}

УДК 636.237.21.082.355.064.6

DOI: $10.31563 / 1684-7628-2019-51-3-52-58$

А.И. Любимов, Ю.В. Исупова

\section{ИНТЕНСИВНОСТЬ РОСТА И РАЗВИТИЯ РЕМОНТНЫХ ТЕЛОК ЧЕРНО-ПЕСТРОЙ ПОРОДЫ В ЗАВИСИМОСТИ ОТ ПРОИСХОЖДЕНИЯ}

\footnotetext{
Ключевые слова: рост; развитие; абсолютный прирост; относительный прирост; среднесуточный прирост; промеры телосложения; ремонтные телки; линейная принадлежность.
}

Введение. Для ремонта стада необходим тщательный отбор животных по их развитию, экстерьеру и приспособленности к содержанию в промышленных условиях. Специалистам важно учитывать развитие мускулатуры, крепость костяка и конечностей отбираемых животных. При завершении бонитировки в хозяйстве намечаются лучшие высокопродуктивные коровы, потомство которых предназначается для ремонта собственного стада. Основными критериями при этом служат приспособленность животных к определенным технологическим условиям и их развитие $[3,7,11]$. Известно, что породные и продуктивные качества животных закладываются на ранних стадиях эмбриогенеза и формируются в процессе индивидуального развития животных. Качество ремонтного молодняка зависит от многих факторов [2, 13, 14 16]. Получить здоровых и хорошо развитых ремонтных телок с последующей высокой продуктивностью можно только при скармливании полноценных, сбалансированных рационов, учитывающих потребности растущих животных на всех стадиях развития и способствующих формированию интересующего селекционера направления продуктивности. В период выращивания ремонтного молодняка необходимо контролировать его рост и развитие и анализировать получаемые результаты $[4,5,8,10,12]$. На уровень молочной продуктивности стада, здоровье и плодовитость коров существенное влияние оказывает также технология выращивания молодняка. Показатели роста и развития, возраст пер- вого осеменения и отела зависят от многих слагаемых. Главной целью выращивания, как правило, является живая масса и продуктивность будущих коров. При любой цели ремонтные телки должны быть подготовлены к длительной и высокопродуктивной жизни. Практикам хорошо известно, что недостаточно развитый молодняк имеет трудности во время первого отела и в последующем низкую молочную продуктивность, что приводит к ранней выбраковке животных $[1,6,9,15]$.

Целью исследований явилось изучение особенностей роста и развития ремонтных телок черно-пестрой породы различной линейной принадлежности в АО «Учхоз Июльское Ижевской ГСХА» Воткинского района Удмуртской Республики. Для выполнения поставленной цели были определены следующие задачи: 1. Изучить технологию содержания ремонтного молодняка в анализируемом предприятии. 2. Проследить динамику роста живой массы ремонтных телок от рождения до года. 3. Провести анализ изменения промеров телосложения телок с возрастом. 4. Выявить различия в особенностях роста и развития ремонтного молодняка в зависимости от происхождения.

Условия, материалы и методы исследования. Исследования проведены в 2017-2018 гг. в АО «Учхоз Июльское Ижевской ГСХА» Воткинского района Удмуртской Республики. Нами были изучены показатели абсолютного, среднесуточного и относительного приростов живой массы, а также динамика промеров телосложе- 
ния ремонтных телок черно-пестрой породы за период выращивания. Материалом исследования послужили данные зоотехнического и племенного учета (журналы выращивания молодняка, журналы взвешиваний, данные бонитировки) и результаты собственных исследований. Живая масса определялась путем индивидуального взвешивания телят при рождении, затем в возрасте 1, 3, 6, 9 и 12 месяцев. По показателям живой массы рассчитывали абсолютный, относительный и среднесуточный приросты. В возрасте 1, 3, 6, 9 и 12 месяцев у ремонтных телок снимали следующие промеры телосложения: высота в холке, высота в крестце, косая длина туловища, глубина груди, ширина груди, обхват груди, ширина в маклоках, обхват пясти. Анализ показателей роста и развития ремонтного молодняка проводился в зависимости от происхождения, то есть для исследования было отобрано по 10 голов телок трех основных линий, разводимых в хозяйстве: Вис Бэк Айдиал 1013 415, Монтвик Чифтейн 95679 и Рефлекш Соверинг 198998.

Для проведения отелов в хозяйстве имеются родильные отделения. После отела теленка помещают в индивидуальную клетку, а корову - в послеродовое отделение, где ее сразу доят и молозиво выпаивают теленку. В индивидуальной клетке теленок содержится 10 дней, получая молозиво матери, чай из трав. В этот период проводят мечение телят, каждому теленку присваивают индивидуальный номер. Если состояние теленка удовлетворительное, он с 10-дневного возраста переводится в групповую клетку по 67 голов на деревянных полах. Телят приучают к минеральным кормам, овсу, сену. С 3 до 7 месяцев телят содержат в групповых клетках по 78 голов. Поение и кормление осуществляется из групповых поилок. Кормят сеном, концентрированными кормами. Навоз убирают скребковым транспортером ТСН-160. Корма раздают вручную. Для содержания телок 7-18 месяцев применяют беспривязно-боксовую систему. Телки располагаются по 14-18 голов. Кормление и поение - из групповых поилок и кормушек. Кормят сочными кормами, сеном, концентрированными кормами. В каждом боксе свободный доступ к мелу и соли. Сочные корма раздают с помощью миксера. Вентиляция естественная приточно-вытяжная. Телкам предоставляют моцион в загонах. Среднесуточные приросты тесно связаны с вопросами кормления. Согласно схеме кормления до шестимесячного возраста, телятам скармливают следующее количество кор- мов: молоко 480 кг, овес цельный 25 кг, концентраты 300 кг, сено 233 кг, силос (сенаж) 285 кг, соль 2,65 кг, мел кормовой 1,9 кг. Такое кормление предусматривает получение живой массы в конце периода 180 кг.

Результаты исследования. Наследственные факторы (порода, направление продуктивности, генотип, линия, семейство и т. п.) определенным образом влияют на показатели роста и развития молодняка сельскохозяйственных животных. В таблице 1 приведена сравнительная характеристика интенсивности роста ремонтного молодняка линий В.Б. Айдиал, М. Чифтейн и Р. Соверинг. Проведя анализ таблицы, можно сказать, что телки линии В.Б. Айдиал в возрасте 1-го месяца по показателю абсолютного прироста превышают своих сверстниц линий М. Чифтейн и Р. Соверинг на 1,9 и 1,4 кг соответственно. Также молодняк этой линии превышает своих сверстниц по такому показателю, как относительный прирост, на 10,3 и 7,3 \% соответственно. Различия между признаками недостоверны. В 3-месячном возрасте телки линии В.Б. Айдиал по показателю абсолютного прироста также превышают аналогов на 0,3-0,6 кг, по среднесуточному приросту - на 6,0-9,9 г и по относительному приросту - на 3,3-7,4 \%. С 6-месячного возраста начинают доминировать по показателям интенсивности роста телки линии Р. Соверинг. По абсолютному приросту разница составляет от 2,1 до 2,6 кг, по среднесуточному - 22,9-28,8 г, по относительному приросту 2,5-3,5 \%. В следующем возрастном периоде молодняк данной линии показывает также наибольшую интенсивность роста. В возрасте 9 месяцев разница в сравнении с телками линий В.Б. Айдиал и М. Чифтейн по абсолютному приросту составляет от 4,5 до 11,3 кг, по среднесуточному - от 49,1 до 197,4 г, по относительному - от 2,1 до $6,1 \%$. В возрасте 12 месяцев ремонтные телки трех анализируемых линий по показателям интенсивности роста практически не отличаются, но молодняк линии В.Б. Айдиал имеет более высокие значения по сравнению со сверстницами по абсолютному приросту на $0,3-$ 0,4 кг, среднесуточному - на 3,3-5,0 г, по относительному приросту разница составляет от 0,1 до 0,8 \%. Разница по всем показателям за исследуемый период (1-12 месяцев) между сравниваемыми группами является недостоверной. При сравнении показателей интенсивности роста и развития ремонтных телок внутри линий пришли к выводам, что в возрасте 3 месяца среднесуточные приросты выше, чем в возрасте 1 месяц, у телок анализируемых линий на 241295,8 г, разница является достоверной (Р $\geq$ 
0,999). Такая же динамика наблюдается в возрасте 9-12 месяцев, среднесуточные приросты в
12 месяцев ниже, чем в 9 месяцев, в пределах от 340 до 392,3 г.

Таблица 1 Интенсивность роста и развития ремонтных телок разных линий

\begin{tabular}{|c|c|c|c|c|c|c|c|c|c|c|}
\hline \multirow{3}{*}{ Показатель } & \multicolumn{10}{|c|}{ Возраст, мес. } \\
\hline & \multicolumn{2}{|c|}{1} & \multicolumn{2}{|c|}{3} & \multicolumn{2}{|c|}{6} & \multicolumn{2}{|c|}{9} & \multicolumn{2}{|c|}{12} \\
\hline & $\mathrm{X} \pm \mathrm{m}$ & $\mathrm{Cv}, \%$ & $\mathrm{X} \pm \mathrm{m}$ & $\mathrm{Cv}, \%$ & $\mathrm{X} \pm \mathrm{m}$ & $\mathrm{Cv}, \%$ & $\mathrm{X} \pm \mathrm{m}$ & $\mathrm{Cv}, \%$ & $\mathrm{X} \pm \mathrm{m}$ & $\mathrm{Cv}, \%$ \\
\hline Линия & \multicolumn{10}{|c|}{ В.Б. Айдиал $(\mathrm{n}=7)$} \\
\hline Живая масса, кг & $\begin{array}{c}46,8 \pm \\
1,5\end{array}$ & 8,5 & $\begin{array}{c}89 \pm \\
4,1\end{array}$ & 12,5 & $\begin{array}{c}149,7 \pm \\
4,1\end{array}$ & 7,4 & $\begin{array}{c}218,8 \pm \\
6,2\end{array}$ & 7,5 & $\begin{array}{c}257,3 \pm \\
6,2\end{array}$ & 5,7 \\
\hline Абсолютный прирост, кг & $\begin{array}{c}13,8 \pm \\
0,5 \\
\end{array}$ & 10,2 & $\begin{array}{c}42,1 \pm \\
2,9\end{array}$ & 18,6 & $\begin{array}{c}60,7 \pm \\
5,4\end{array}$ & 23,7 & $\begin{array}{c}69,1 \pm \\
3,9\end{array}$ & 15,0 & $\begin{array}{c}38,5 \pm \\
1,47\end{array}$ & 10,2 \\
\hline Среднесуточный прирост, г & $\begin{array}{c}461,3 \pm \\
16,0\end{array}$ & 10,2 & $\begin{array}{l}702,3 \pm \\
49,3 * * *\end{array}$ & 18,6 & $\begin{array}{c}674,6 \pm \\
60,5 \\
\end{array}$ & 23,7 & $\begin{array}{r}768,2 \pm \\
43,5 * * *\end{array}$ & 15,0 & $\begin{array}{c}428,3 \pm \\
16,3\end{array}$ & 10,2 \\
\hline Относительный прирост, \% & $\begin{array}{c}41,8 \pm \\
2,5 \\
\end{array}$ & 18,8 & $\begin{array}{c}89,6 \pm \\
4,5 \\
\end{array}$ & 13,3 & $\begin{array}{c}70,1 \pm \\
8,3 \\
\end{array}$ & 31,4 & $\begin{array}{c}46,3 \pm \\
2,7 \\
\end{array}$ & 15,6 & $\begin{array}{c}17,6 \pm \\
1,1 \\
\end{array}$ & 16,2 \\
\hline Линия & \multicolumn{10}{|c|}{ М. Чифтейн $(\mathrm{n}=11)$} \\
\hline Живая масса, кг & $\begin{array}{c}49,6 \pm \\
1,6\end{array}$ & 10,4 & $\begin{array}{c}91,2 \pm \\
5,6\end{array}$ & 20,2 & $\begin{array}{c}151,4 \pm \\
7,8\end{array}$ & 17,1 & $\begin{array}{c}213,6 \pm \\
8,4\end{array}$ & 13,1 & $\begin{array}{c}251,7 \pm \\
7,0\end{array}$ & 9,3 \\
\hline Абсолютный прирост, кг & $\begin{array}{c}11,9 \pm \\
0,9 \\
\end{array}$ & 28,2 & $\begin{array}{c}41,6 \pm \\
4,2\end{array}$ & 33,8 & $\begin{array}{c}60,2 \pm \\
5,1\end{array}$ & 28,1 & $\begin{array}{c}62,3 \pm \\
3,4\end{array}$ & 18,3 & $\begin{array}{c}38,1 \pm \\
2,3\end{array}$ & 20,5 \\
\hline Среднесуточный прирост, г & $\begin{array}{c}396,6 \pm \\
17,1 \\
\end{array}$ & 12,7 & $\begin{array}{l}692,4 \pm \\
70,5 * * * \\
\end{array}$ & 33,8 & $\begin{array}{c}668,7 \pm \\
56,7\end{array}$ & 28,1 & $\begin{array}{c}691,9 \pm \\
38,1 * * *\end{array}$ & 18,3 & $\begin{array}{c}423,3 \pm \\
24,7\end{array}$ & 18,5 \\
\hline Относительный прирост, \% & $\begin{array}{c}31,5 \pm \\
2,6 \\
\end{array}$ & 32,8 & $\begin{array}{c}82,2 \pm \\
7,3 \\
\end{array}$ & 29,3 & $\begin{array}{c}69,1 \pm \\
7,5 \\
\end{array}$ & 36,0 & $\begin{array}{c}42,3 \pm \\
3,2 \\
\end{array}$ & 25,1 & $\begin{array}{c}17,5 \pm \\
1,8 \\
\end{array}$ & 33,5 \\
\hline Линия & \multicolumn{10}{|c|}{ Р. Соверинг $(\mathrm{n}=9)$} \\
\hline Живая масса, кг & $\begin{array}{c}48,3 \pm \\
2,3\end{array}$ & 14,4 & $\begin{array}{c}90,1 \pm \\
4,8\end{array}$ & 16,0 & $\begin{array}{c}152,9 \pm \\
4,8\end{array}$ & 9,4 & $\begin{array}{c}226,4 \pm \\
7,3\end{array}$ & 9,7 & $\begin{array}{c}264,6 \pm \\
5,2\end{array}$ & 6,0 \\
\hline Абсолютный прирост, кг & $\begin{array}{c}12,4 \pm \\
1,3\end{array}$ & 31,3 & $\begin{array}{c}41,8 \pm \\
3,1\end{array}$ & 22,0 & $\begin{array}{c}62,8 \pm \\
3,4\end{array}$ & 16,2 & $\begin{array}{c}73,6 \pm \\
5,1\end{array}$ & 20,8 & $\begin{array}{c}38,2 \pm \\
2,9\end{array}$ & 25,1 \\
\hline Среднесуточный прирост, г & $\begin{array}{c}413,3 \pm \\
16,9 \\
\end{array}$ & 9,7 & $\begin{array}{l}696,3 \pm \\
51,1 * * *\end{array}$ & 22,0 & $\begin{array}{c}697,5 \pm \\
37,7 \\
\end{array}$ & 16,2 & $\begin{array}{l}817,3 \pm \\
56,6^{* * *}\end{array}$ & 20,8 & $\begin{array}{c}425,0 \pm \\
12,7 \\
\end{array}$ & 14,0 \\
\hline Относительный прирост, \% & $\begin{array}{c}34,5 \pm \\
2,9\end{array}$ & 29,3 & $\begin{array}{c}86,3 \pm \\
5,5\end{array}$ & 19,0 & $\begin{array}{c}72,6 \pm \\
7,8 \\
\end{array}$ & 32,1 & $\begin{array}{c}48,4 \pm \\
3,7 \\
\end{array}$ & 22,9 & $\begin{array}{c}16,8 \pm \\
1,8\end{array}$ & 33,2 \\
\hline
\end{tabular}

Примечание: *** $\mathrm{P} \geq 0,999$.

В таблице 2 представлена динамика промеров телок разных линий с возрастом. Анализируя данные таблицы 2, можно отметить, что телки линии В.Б. Айдиал в возрасте 1-го месяца по показателю высоты в холке превышают своих сверстниц линий М. Чифтейн и Р. Соверинг на 0,7 и 4,6 см $(\mathrm{P} \geq 0,99)$ соответственно. Также молодняк этой линии превышает своих сверстниц по такому показателю, как ширина груди, на 0,3 и 0,4 см соответственно. Различия между признаками недостоверны. В 3-месячном возрасте телки данной линии по промеру высоты в холке превышали своих сверстниц на 0,6-1,6 см. В возрасте 9 месяцев они превышали аналогов по промерам: глубина груди - на $0,2-$ $0,5 \mathrm{~cm}$, ширина в маклоках - на 0,5 см (разница недостоверна). Молодняк линии В.Б. Айдиал в возрасте 12 месяцев превосходил только по одному показателю - глубине груди (0,4-2,9 см). Наибольшая достоверная разница наблюдается при сравнении со сверстницами линии М. Чиф- тейн и составляет 2,9 см $(\mathrm{P} \geq 0,99)$. Телки линии М. Чифтейн превышают аналогов по следующим промерам: высота в крестце - на 0,6-1,0 cм, глубина груди - на 1,8-2,8 cм, обхват груди - на $1,2-1,8$ см, ширина в маклоках - на $0,4-0,7$ см.

Молодняк линии М. Чифтейн превышает сверстниц других линий в возрасте 3 месяца по таким промерам, как глубина груди (1,6-2,1 cм), обхват груди (1,6-2,1 см), ширина в маклоках $(0,8-0,9$ см), обхват пясти $(1,5-2,9$ см). Более существенная и достоверная разница наблюдается в возрасте 3-х месяцев по промерам: глубина груди, обхват груди - составляет $2,1 \mathrm{~cm}(\mathrm{P} \geq$ $0,99)$, ширина в маклоках $-0,9$ см $(\mathrm{P} \geq 0,95)$, обхват пясти $-2,9$ см $(\mathrm{P} \geq 0,999)$. В возрасте 6 месяцев молодняк линии М. Чифтейн превосходит сверстниц по высоте в крестце (0,4-0,7 см), глубине груди (1,4 см), обхвату груди (2,1-2,5 cм). Наибольшая разница наблюдается в данном возрасте по промеру обхвата груди: 2,5 см (Р $\geq$ $0,95)$. 
Таблица 2 Изменение промеров телосложения телок разных линий

\begin{tabular}{|c|c|c|c|c|c|c|c|c|c|c|}
\hline \multirow{3}{*}{ Показатель } & \multicolumn{10}{|c|}{ Возраст, мес. } \\
\hline & \multicolumn{2}{|c|}{1} & \multicolumn{2}{|c|}{3} & \multicolumn{2}{|c|}{6} & \multicolumn{2}{|c|}{9} & \multicolumn{2}{|c|}{12} \\
\hline & $\mathrm{X} \pm \mathrm{m}$ & $\mathrm{Cv}, \%$ & $\mathrm{X} \pm \mathrm{m}$ & $\mathrm{Cv}, \%$ & $\mathrm{X} \pm \mathrm{m}$ & $\mathrm{Cv}, \%$ & $\mathrm{X} \pm \mathrm{m}$ & $\mathrm{Cv}, \%$ & $\mathrm{X} \pm \mathrm{m}$ & $\mathrm{Cv}, \%$ \\
\hline Линия & \multicolumn{10}{|c|}{ В.Б. Айдиал $(\mathrm{n}=7)$} \\
\hline Высота в холке, см & $\begin{array}{l}87,7 \pm \\
1,0 * *\end{array}$ & 3,1 & $\begin{array}{c}101,6 \pm \\
0,5\end{array}$ & 1,3 & $\begin{array}{c}115,4 \pm \\
1,0\end{array}$ & 2,4 & $\begin{array}{c}117,8 \pm \\
0,8\end{array}$ & 1,7 & $\begin{array}{c}119,1 \pm \\
0,7\end{array}$ & 1,5 \\
\hline Высота в крестце, см & $\begin{array}{c}95,4 \pm \\
0,5\end{array}$ & 1,5 & $\begin{array}{c}107,0 \pm \\
0,5\end{array}$ & 1,2 & $\begin{array}{c}118,5 \pm \\
0,5\end{array}$ & 1,1 & $\begin{array}{c}121,1 \pm \\
0,3\end{array}$ & 0,6 & $\begin{array}{c}123,8 \pm \\
0,2\end{array}$ & 0,4 \\
\hline Косая длина туловища, см & $\begin{array}{c}77,0 \pm \\
0,9\end{array}$ & 3,2 & $\begin{array}{c}98,0 \pm \\
0,7\end{array}$ & 1,9 & $\begin{array}{c}119,0 \pm \\
0,9\end{array}$ & 2,0 & $\begin{array}{c}125,1 \pm \\
0,6\end{array}$ & 1,3 & $\begin{array}{c}131,3 \pm \\
1,4\end{array}$ & 1,4 \\
\hline Глубина груди, см & $\begin{array}{c}33,3 \pm \\
1,1\end{array}$ & 9,0 & $\begin{array}{c}43,3 \pm \\
0,6\end{array}$ & 3,4 & $\begin{array}{c}53,3 \pm \\
0,3\end{array}$ & 1,4 & $\begin{array}{c}56,6 \pm \\
0,5\end{array}$ & 2,2 & $\begin{array}{c}59,9 \pm \\
0,9 * *\end{array}$ & 4,0 \\
\hline Ширина груди, см & $\begin{array}{c}21,1 \pm \\
0,5\end{array}$ & 5,7 & $\begin{array}{c}28,3 \pm \\
0,3\end{array}$ & 2,5 & $\begin{array}{c}35,5 \pm \\
0,8\end{array}$ & 5,6 & $\begin{array}{c}38,7 \pm \\
0,3\end{array}$ & 2,1 & $\begin{array}{c}41,9 \pm \\
0,2\end{array}$ & 1,2 \\
\hline Обхват груди, см & $\begin{array}{c}94,4 \pm \\
0,4\end{array}$ & 1,0 & $\begin{array}{c}124,3 \pm \\
0,7\end{array}$ & 1,5 & $\begin{array}{c}154,1 \pm \\
1,3\end{array}$ & 2,2 & $\begin{array}{c}160,5 \pm \\
0,7\end{array}$ & 1,2 & $\begin{array}{c}166,8 \pm \\
0,4\end{array}$ & 0,7 \\
\hline Ширина в маклоках, см & $\begin{array}{c}18,0 \pm \\
0,5\end{array}$ & 7,2 & $\begin{array}{c}27,0 \pm \\
0,3\end{array}$ & 3,0 & $\begin{array}{c}36,1 \pm \\
0,5\end{array}$ & 3,8 & $\begin{array}{c}38,6 \pm \\
0,4\end{array}$ & 2,7 & $\begin{array}{c}41,1 \pm \\
0,4\end{array}$ & 2,9 \\
\hline Обхват пясти, см & $\begin{array}{c}11,6 \pm \\
0,4\end{array}$ & 10,4 & $\begin{array}{c}13,4 \pm \\
0,4\end{array}$ & 8,3 & $\begin{array}{c}16,1 \pm \\
0,4\end{array}$ & 6,9 & $\begin{array}{c}17,0 \pm \\
0,3\end{array}$ & 3,9 & $\begin{array}{c}17,9 \pm \\
0,2\end{array}$ & 2,7 \\
\hline Линия & \multicolumn{10}{|c|}{ М. Чифтейн (n = 11) } \\
\hline Высота в холке, см & $\begin{array}{c}87,0 \pm \\
0,4\end{array}$ & 1,4 & $\begin{array}{c}101,0 \pm \\
0,3\end{array}$ & 1,0 & $\begin{array}{c}115,1 \pm \\
0,4\end{array}$ & 1,1 & $\begin{array}{c}116,9 \pm \\
0,3\end{array}$ & 0,9 & $\begin{array}{c}119,6 \pm \\
0,3\end{array}$ & 0,7 \\
\hline Высота в крестце, см & $\begin{array}{c}96,4 \pm \\
0,6\end{array}$ & 2,0 & $\begin{array}{c}107,6 \pm \\
0,4\end{array}$ & 1,2 & $\begin{array}{c}118,9 \pm \\
0,3\end{array}$ & 0,8 & $\begin{array}{c}121,1 \pm \\
0,2\end{array}$ & 0,5 & $\begin{array}{c}123,4 \pm \\
0,2\end{array}$ & 0,7 \\
\hline Косая длина туловища, см & $\begin{array}{c}75,7 \pm \\
0,7\end{array}$ & 2,9 & $\begin{array}{c}96,7 \pm \\
0,8\end{array}$ & 2,9 & $\begin{array}{c}117,8 \pm \\
1,1\end{array}$ & 3,0 & $\begin{array}{c}123,1 \pm \\
0,6\end{array}$ & 1,4 & $\begin{array}{c}131,6 \pm \\
0,8\end{array}$ & 1,6 \\
\hline Глубина груди, см & $\begin{array}{l}35,1 \pm \\
0,5 * *\end{array}$ & 5,0 & $\begin{array}{c}44,9 \pm \\
0,5^{* *}\end{array}$ & 3,8 & $\begin{array}{c}54,7 \pm \\
0,7\end{array}$ & 4,0 & $\begin{array}{c}55,9 \pm \\
0,4\end{array}$ & 2,6 & $\begin{array}{c}57,0 \pm \\
0,3\end{array}$ & 2,0 \\
\hline Ширина груди, см & $\begin{array}{c}20,8 \pm \\
0,3\end{array}$ & 4,2 & $\begin{array}{c}28,6 \pm \\
0,2\end{array}$ & 2,3 & $\begin{array}{c}36,4 \pm \\
0,3\end{array}$ & 2,5 & $\begin{array}{c}39,5 \pm \\
0,1\end{array}$ & 0,9 & $\begin{array}{c}42,6 \pm \\
0,2\end{array}$ & 1,4 \\
\hline Обхват груди, см & $\begin{array}{c}95,6 \pm \\
0,6\end{array}$ & 2,2 & $\begin{array}{c}125,9 \pm \\
0,5^{* *}\end{array}$ & 1,3 & $\begin{array}{c}156,2 \pm \\
0,8^{*}\end{array}$ & 1,7 & $\begin{array}{c}161,7 \pm \\
0,4\end{array}$ & 0,8 & $\begin{array}{c}167,2 \pm \\
0,2\end{array}$ & 0,4 \\
\hline Ширина в маклоках, см & $\begin{array}{c}18,7 \pm \\
0,5\end{array}$ & 8,3 & $\begin{array}{c}27,9 \pm \\
0,3^{*}\end{array}$ & 3,6 & $\begin{array}{c}37,0 \pm \\
0,4\end{array}$ & 3,5 & $\begin{array}{c}38,6 \pm \\
0,4\end{array}$ & 3,6 & $\begin{array}{c}41,2 \pm \\
0,2\end{array}$ & 1,6 \\
\hline Обхват пясти, см & $\begin{array}{c}13,2 \pm \\
0,6^{*} \\
\end{array}$ & 15,8 & $\begin{array}{l}14,9 \pm \\
0,4 * * *\end{array}$ & 8,4 & $\begin{array}{c}16,5 \pm \\
0,2 \\
\end{array}$ & 4,6 & $\begin{array}{c}17,2 \pm \\
0,1 \\
\end{array}$ & 3,3 & $\begin{array}{c}17,9 \pm \\
0,1 \\
\end{array}$ & 2,7 \\
\hline Линия & \multicolumn{10}{|c|}{ Р. Соверинг $(\mathrm{n}=9)$} \\
\hline Высота в холке, см & $\begin{array}{c}83,1 \pm \\
1,1\end{array}$ & 3,8 & $\begin{array}{c}100,1 \pm \\
0,8\end{array}$ & 2,4 & $\begin{array}{c}117,1 \pm \\
0,9\end{array}$ & 2,2 & $\begin{array}{c}118,3 \pm \\
0,5^{*}\end{array}$ & 1,3 & $\begin{array}{c}119,5 \pm \\
0,8\end{array}$ & 2,0 \\
\hline Высота в крестце, см & $\begin{array}{c}95,8 \pm \\
0,4\end{array}$ & 1,2 & $\begin{array}{c}107,3 \pm \\
0,3\end{array}$ & 0,9 & $\begin{array}{c}118,2 \pm \\
0,6\end{array}$ & 1 , & $\begin{array}{c}121,2 \pm \\
0,3\end{array}$ & 0,9 & $\begin{array}{c}124,1 \pm \\
0,9\end{array}$ & 1,8 \\
\hline Косая длина туловища, см & $\begin{array}{c}77,9 \pm \\
0,4^{*}\end{array}$ & 1,6 & $\begin{array}{c}98,9 \pm \\
0,4^{*}\end{array}$ & 1,3 & $\begin{array}{c}119,8 \pm \\
1,0\end{array}$ & 2,6 & $\begin{array}{l}125,3 \pm \\
0,4 * * *\end{array}$ & 0,9 & $\begin{array}{c}132,1 \pm \\
0,4\end{array}$ & 0,7 \\
\hline Глубина груди, см & $\begin{array}{c}32,3 \pm \\
0,8\end{array}$ & 7,1 & $\begin{array}{c}42,8 \pm \\
0,5\end{array}$ & 3,5 & $\begin{array}{c}53,3 \pm \\
0,3\end{array}$ & 1,8 & $\begin{array}{c}56,4 \pm \\
0,2\end{array}$ & 1,0 & $\begin{array}{c}59,5 \pm \\
0,4\end{array}$ & 2,1 \\
\hline Ширина груди, см & $\begin{array}{c}20,7 \pm \\
0,2\end{array}$ & 3,4 & $\begin{array}{c}28,8 \pm \\
0,3\end{array}$ & 3,0 & $\begin{array}{c}36,8 \pm \\
0,6\end{array}$ & 4,8 & $\begin{array}{c}39,5 \pm \\
0,3 \\
\end{array}$ & 2,5 & $\begin{array}{c}42,2 \pm \\
0,3\end{array}$ & 2,0 \\
\hline Обхват груди, см & $\begin{array}{c}93,8 \pm \\
0,9\end{array}$ & 3,0 & $\begin{array}{c}123,8 \pm \\
0,5\end{array}$ & 1,3 & $\begin{array}{c}153,7 \pm \\
0,7\end{array}$ & 1,3 & $\begin{array}{c}160,4 \pm \\
0,4\end{array}$ & 0,8 & $\begin{array}{c}167,3 \pm \\
0,3\end{array}$ & 0,3 \\
\hline Ширина в маклоках, см & $\begin{array}{c}18,4 \pm \\
0,4\end{array}$ & 7,1 & $\begin{array}{c}27,1 \pm \\
0,4\end{array}$ & 4,7 & $\begin{array}{c}35,5 \pm \\
0,8\end{array}$ & 6,4 & $\begin{array}{c}38,1 \pm \\
0,5\end{array}$ & 4,1 & $\begin{array}{c}40,7 \pm \\
0,5\end{array}$ & 3,8 \\
\hline Обхват пясти, см & $\begin{array}{c}11,1 \pm \\
0,5\end{array}$ & 18,5 & $\begin{array}{c}12,0 \pm \\
0,3\end{array}$ & 6,3 & $\begin{array}{c}16,6 \pm \\
0,1\end{array}$ & 1,6 & $\begin{array}{c}17,2 \pm \\
0,1\end{array}$ & 1,2 & $\begin{array}{c}17,9 \pm \\
0,1\end{array}$ & 1,2 \\
\hline
\end{tabular}

Примечание: * $\mathrm{P} \geq 0,95 ; * * \mathrm{P} \geq 0,99 ; * * * \mathrm{P} \geq 0,999$. 
Ремонтные телки линии Р. Соверинг в возрасте 1-го и 3-х месяцев являются самыми рас-тянутыми. Промер косой длины туловища превышает сверстниц линий В.Б. Айдиал и М. Чифтейн на 0,9-2,2 см и составляет 77,9 и 98,9 см соответственно $(\mathrm{P} \geq 0,95)$. В возрасте 6 месяцев молодняк данной линии превышает аналогов по промерам: высота в холке (1,7-2,0 см), косая длина туловища $(0,8-2,1$ см), ширина груди $(0,4-1,3$ см), обхват пясти $(0,1-0,5 \mathrm{~cm})$, разница недостоверна. В 9-месячном возрасте промеры высоты в холке (0,5-1,4 см), высоты в крестце $(0,1$ см), косой длины туловища $(2,2$ см), ширины груди $(0,8-0,9$ см), обхвата пясти $(0,2 \mathrm{~cm})$ выше промеров сверстниц в этом же возрасте. Наиболее достоверная и существенная разница наблюдается по промерам высоты в холке 1,4 cм $(\mathrm{P} \geq 0,95)$ и косой длины туловища 4,2 см $(\mathrm{P} \geq$ 0,999). В 12 месяцев показатели промеров телок линии Р. Соверинг превышают показатели аналогов по высоте в кресте $(0,3-0,7$ см), косой длине туловища $(0,5-0,8 \mathrm{~cm})$, обхвату груди $(0,1-0,5$ см). Разница не достоверна. В целом по развитию телок можно отметить, что к 12-ме- сячному возрасту молодняк анализируемых линий по высотным промерам практически одинаков, разница составляет от 0 до 0,5 см. По развитию грудной клетки в глубину наиболее развитым является ремонтный молодняк линии В.Б. Айдиал, разница составляет от 0,4 до 2,9 см. По остальным промерам телки данных линий практически не отличаются друг от друга.

Выводы. Телки линий Р. Соверинг и В.Б. Айдиал в возрасте 9 месяцев обладают наибольшими абсолютными и среднесуточными приростами, которые равны 73,6 кг, 817,3 г и 69,1 кг, 768,2 г соответственно. Ремонтный молодняк линии М. Чифтейн во все анализируемые возрастные периоды показывает наименьшую интенсивность роста. Наибольшее увеличение промеров телосложения с возрастом наблюдается у телок линии В.Б. Айдиал. До 6-месячного возраста они превышали по основным промерам своих сверстниц на 6-10 см. С 9-месячного возраста наибольшее увеличение промеров наблюдается у молодняка линии Р. Соверинг, данные показатели выше, чем у сверстниц, на 2-3 см.

\section{Библиографический список}

1. Ачкасова, Е.В. Влияние паратипических факторов на молочную продуктивность и технологические свойства молока коров-первотелок черно-пестрой породы [Текст]: дис. ... канд. c.-х. наук / Е.В. Ачкасова. Ижевск: Ижевская ГСХА, 2009. $166 \mathrm{c}$.

2. Батанов, С.Д. Взаимосвязь состава крови телят с интенсивностью их роста и развития [Текст] / С.Д. Батанов, Г.Ю. Березкина // Молочное и мясное скотоводство. 2004. № 7. С. 41-42.

3. Березкина, Г.Ю. Возрастные изменения роста и развития ремонтных телок [Текст]/ Г.Ю. Березкина // Теория и практика - устойчивому развитию агропромышленного комплекса: материалы Всероссийский научно-практической конференции. Министерство сельского хозяйства Российской федерации, Ижевская ГСХА. Ижевск, 2015. С. 69-72.

4. Валеев, А.Н. Энергетические добавки в рационах нетелей и коров-первотелок чернопестрой породы [Текст] / А.Н. Валеев, Е.М. Кислякова, Ю.В. Исупова // Аграрный вестник Урала. 2011. № 4 (83). С. 34-36.

5. Волков, 3.Я. Использование заменителей цельного молока при интенсивном выращивании ремонтных телок [Текст] / 3.Я. Волков,
С.Д. Батанов, Е.М. Кислякова, Н.М. Тогушев, Р.P. Закирова // Зоотехния. 2006. № 7. С. 13-15.

6. Гиниятуллин, Ш.Ш. Рост, развитие и воспроизводительные особенности чистопородных и помесных телок [Текст] / Ш.Ш. Гиниятуллин // Актуальные проблемы и пути развития животноводства: материалы Всероссийской научно-практической конференции в честь 75летия основания кафедры физиологии и биохимии животных, памяти профессора П.Я. Гущина. Уфа: Башкирский ГАУ, 2009. С. 84-85.

7. Заднепрянский, И.П. Рост и развитие ремонтных телок голштинской породы в условиях интенсивных технологий [Текст] / И.П. Заднепрянский, Ю.В. Щегликов // Молочное и мясное скотоводство. 2014. № 5. С. 32-33.

8. Ижболдина, С.Н. Влияние применения престартерных и стартерных комбикормов в молочный период на рост и развитие телок [Текст] / С.Н. Ижболдина, Н.В. Селезнева // Молочное и мясное скотоводство. 2013. № 5. С. 21-23.

9. Исупова, Ю.В. Хозяйственные и биологические особенности крупного рогатого скота черно-пестрой породы разного уровня продуктивности [Текст]: дис. ... канд. с.-х. наук / Ю.В. Исупова. Ижевск: Ижевская ГСХА, 2005. 158 с. 
10. Кудрин, М.Р. Полноценное кормление основа высокой молочной продуктивности коров [Текст] / М.Р. Кудрин, Е.М. Кислякова // Ученые записки Казанской государственной академии ветеринарной медицины им. Н.Э. Баумана. 2015. № 223. С. 96-101.

11. Кудрин, М.Р. Рост, развитие, воспроизводительные качества ремонтных телок по возрастным периодам [Текст] / М.Р. Кудрин, С.Н. Ижболдина // Известия Горского государственного аграрного университета. 2016. Т. 53. № 1. С. 34-39.

12. Ломаева, А.А. Комбикорма-стартеры в кормлении телят младших возрастов [Текст] / А.А. Ломаева, Е.М. Кислякова // Инновационные технологии в животноводстве и перспективы их использования в ФСИН России: материалы Всероссийской научно-практической конференции. Федеральное казенное образовательное учреждение Пермский институт Федеральной службы исполнения наказаний России. Пермь, 2013. С. 13-19.

13. Любимов, А.И. Характеристика продуктивных качеств линий и ветвей в ОАО «Путь
Ильича» Завьяловского района Удмуртской Республики [Текст] / А.И. Любимов, Ю.В. Исупова, В.М. Юдин // Вестник Донского государственного аграрного университета. 2015. № 1 (15), ч. 1. C. 74-77.

14. Любимов, А.И. Экстерьерные особенности и молочная продуктивность коров чернопестрой породы разных генераций [Текст] / А.И. Любимов, Е.Н. Мартынова, Ю.В. Исупова, Е.В. Ачкасова, Е.А. Ястребова // Ученые записки Казанской государственной академии ветеринарной медицины им. Н.Э. Баумана. 2018. T. 233. № 1. С. 98-102.

15. Мартынова, Е.Н. Проблема воспроизводства в молочном скотоводстве и пути ее решения [Текст] / Е.Н. Мартынова, Г.В. Азимова, Ю.В. Исупова, В.С. Сухова // Вестник Ижевской ГСХА. 2016. № 3 (48). С. 38-44.

16. Хатанов, К.Ю. Влияние быков-производителей на рост и развитие ремонтных телок в СПК «Килачевский» [Текст] / К.Ю. Хатанов, О.Г. Лоретц // Аграрный вестник Урала. 2013. № 7 (113). C. 67-70.

\section{Сведения об авторах}

1. Любимов Александр Иванович, доктор сельскохозяйственных наук, профессор, ФГБОУ ВО Ижевская ГСХА, УР, г. Ижевск, ул. Студенческая, 11, тел.: (3412) 58-99-48, e-mail: info@izhgsha.ru.

2. Исупова Юлия Викторовна, кандидат сельскохозяйственных наук, доцент, Федеральное государственное бюджетное образовательное учреждение высшего образования Ижевская государственная сельскохозяйственная академия (ФГБОУ ВО Ижевская ГСХА), 426000, Удмуртская Республика, г. Ижевск, ул. Студенческая, 11, тел.: (3412) 77-37-34, e-mail: isupova_79@mail.ru.

В ходе работы проведен анализ показателей абсолютного, среднесуточного и относительного приростов живой массы ремонтных телок черно-пестрой породы в АО «Учхоз Июльское Ижевской ГСХА» Воткинского района Удмуртской Республики за период выращивания. Также изучена динамика промеров телосложения молодняка различного происхождения от рождения до 12-месячного возраста. Условия содержания и кормления ремонтного молодняка в данном предприятии отвечают физиологическим требованиям. Наибольшая интенсивность роста телок наблюдается в период 6-9 месяцев. Так, абсолютный прирост равен 67,8 кг, среднесуточный - 753,5 г. При анализе динамики промеров ремонтного молодняка наблюдается более значительное их увеличение до 6-месячного возраста. Высотные промеры изменились в среднем на 11-15 см, косая длина туловища - на 20, про- меры грудной клетки - на 8-30 см, ширина в маклоках - на 9 и обхват пясти - на 2 см в среднем за анализируемые периоды. В зависимости от происхождения было выявлено, что телки линий Р. Соверинг и В.Б. Айдиал в возрасте 9 месяцев обладают наибольшими абсолютными и среднесуточными приростами, которые равны 73,6 кг, 817,3 г и 69, 1 кг, 768, 2 г соответственно. Ремонтный молодняк линии М. Чифтейн во все анализируемые возрастные периоды показывает наименьшую интенсивность роста. Наибольшее увеличение промеров телосложения с возрастом наблюдается у телок линии В.Б. Айдиал. До 6-месячного возраста они превышали по основным промерам своих сверстниц на 6-10 см. С 9-месячного возраста наибольшее увеличение промеров наблюдается у молодняка линии Р. Соверинг, данные показатели выше аналогичных у сверстниц на 2-3 см. 
A. Lyubimov, Yu. Isupova

\section{GROWTH AND DEVELOPMENT \\ OF BLACK-AND-WHITE REPLACEMENT HEIFERS \\ DEPENDING ON THE ORIGIN}

Key words: growth; absolute gain; relative increase; average daily gain; body measurements; replacement heifers; line distinctive feature.

\section{Authors' personal details}

1. Lyubimov Alexander, Doctor of Agricultural Sciences, Professor, Federal State Budgetary Educational Institution of Higher Education «Izhevsk State Agricultural Academy», Udmurt Republic, Izhevsk, Student St., 11, phone: (3412) 58-99-48, e-mail: info@izhgsha.ru.

2. Isupova Yulia, Candidate of Agricultural Sciences, Associate Professor, Federal State Budgetary Educational Institution of Higher Education «Izhevsk State Agricultural Academy», 426000, Udmurt Republic, Izhevsk, Student St., 11, phone: (3412) 77-37-34, e-mail: isupova_79@mail.ru.

The study analysed absolute, average daily and relative live weight growth indices in replacement of the holstein friesian (black-and-white) heifers for the breeding period. The study was conducted at $\mathrm{AO}$ (JSC) «Uchkhoz Iyulskoe Izhevsk state agricultural academy» in Votkinsk district of Udmurt Republic. Also, the study focused on dynamics of body measurements in the young animals of different origin from birth to the age of 12 months. Maintenance and feeding conditions met the physiological requirements. The heifers demonstrated the highest growth indices at the age of 6-9 months. The absolute weight gain was $67,8 \mathrm{~kg}$, the average daily weight gain was $753,5 \mathrm{~g}$. As for the dynamics of body measurements a significant increase was observed up to the age of 6 months. Height measurements increased by an average of 11-15 cm, oblique body length rose by $20 \mathrm{~cm}$, chest measurements increased

(С Любимов А.И., Исупова Ю.В. by $8-30 \mathrm{~cm}$, hip width grew by $9 \mathrm{~cm}$ and shank measurements increased by $2 \mathrm{~cm}$ on average for the study period. Depending on the origin, it was found that heifers of the lines by R. Sovering and V.B. Ideal had the highest absolute and average daily weight values at the age of 9 months, they were $73,6 \mathrm{~kg}, 817,3 \mathrm{~g}$ and $69,1 \mathrm{~kg}, 768,2 \mathrm{~g}$, respectively. M. Chiftain's line heifers showed the lowest growth indices in all of the analysed age periods. Heifers of the line by V.B. Ideal demonstrated the greatest increase in body measurements with age. Up to the age of 6 months, their main body measurements exceeded other line heifers by $6-10 \mathrm{~cm}$. From the age of 9 months, the largest increase in measurements was observed in R. Sovering' line heifers, these indices were higher by $2-3 \mathrm{~cm}$ than in other line heifers.

УДК 636.082

DOI: 10.31563/1684-7628-2019-51-3-58-63

Т.А. Русских, В.А. Бычкова

\section{ВЛИЯНИЕ ВОЗРАСТА ПЕРВОГО ОСЕМЕНЕНИЯ НА ПРОДУКТИВНОЕ ДОЛГОЛЕТИЕ КОРОВ ЧЕРНО-ПЕСТРОЙ И ХОЛМОГОРСКОЙ ПОРОДЫ}

Ключевые слова: черно-пестрая порода; холмогорская порода; возраст первого плодотворного осеменения; продолжительность продуктивного использования; пожизненная продуктивность.

Введение. Продолжительность продуктивного использования молочного скота является одним из важнейших резервов дальнейшего роста поголовья, совершенствования племенных и продуктивных качеств животных [1]. Вопросу о сроке продуктивного использования крупного рогатого скота в последнее время уделяется большое внимание, так как наблюдается тенден- 
ция снижения сроков использования коров, приводящая к сокращению поголовья молочного скота $[10-12,15,16]$. Это говорит о том, что изза различных проблем со здоровьем (мастит, заболевания конечностей, пищеварительной системы и т. д.) коровы не доживают до возраста, в котором могла бы проявиться их максимальная продуктивность. Помимо сокращения сроков использования происходит снижение молочной продуктивности и ухудшение качества молока. При этом у сельскохозяйственных предприятий повышаются затраты на выращивание и содержание нового поголовья, а также замедляются темпы воспроизводства стада. Наиболее ярко тенденция к сокращению срока использования зачастую проявляется у высокопродуктивных коров $[2,9,13]$. Продуктивное долголетие крупного рогатого скота обусловлено как наследственными (линейная принадлежность, влияние быка-производителя), так и паратипическими (кормление и содержание, продолжительность лактации, сервис-период, сухостойный период, возраст коров и др.) факторами. В тесной взаимосвязи находятся продуктивное долголетие коров и возраст первого плодотворного осеменения $[4,8,13]$. При слишком раннем осеменении телок с низкой живой массой и недостаточной физиологической зрелости организма происходит снижение молочной продуктивности. При слишком позднем осеменении телок возрастают затраты на их выращивание, сокращается количество полученных телят, снижается молочная продуктивность коров $[3,4,5$, 9]. Принято считать, что в среднем первое осеменение телок проводят в 16-18 месяцев, однако при этом необходимо учитывать живую массу и развитие животного, так как несоблюдение этих норм приводит к сокращению времени продуктивного использования $[6,7,14]$.

Целью исследований было изучение влияния возраста первого плодотворного осеменения на продуктивное долголетие коров чернопестрой и холмогорской пород. Для достижения данной цели выполнен ряд задач: определено влияние возраста первого осеменения на продолжительность хозяйственного использования коров черно-пестрой и холмогорской пород; выявлена зависимость пожизненной продуктивности коров двух пород от возраста первого осеменения.

Условия, материалы и методы исследований. Исследование проводилось на двух племенных заводах Удмуртской Республики, занимающихся разведением скота черно-пестрой (АО «Учхоз Июльское ИжГСХА») и холмогорской (СПК «Чутырский») пород. На основании данных племенного учета (программа «Селэкс») была сделана выборка коров, выбывших из стада за последние 5 лет. Животные каждой породы были распределены в 4 группы в зависимости от срока первого плодотворного осеменения. В первую группу вошли коровы, осемененные в возрасте до 15 месяцев, во вторую - осемененные в возрасте 16-17 месяцев, в третью осемененные в 18-19 месяцев и в четвертую осемененные в возрасте старше 20 месяцев. У животных, вошедших в выборку, определяли пожизненный удой за все лактации, массовую долю жира и белка в молоке в среднем за все лактации, пожизненный удой в пересчете на базисные нормы по жиру и белку, а также продолжительность хозяйственного использования коров в лактациях.

Результаты исследования. Сравнительный анализ пожизненной продуктивности и срока использования коров двух пород (таблицы 1, 2) выявил, что коровы черно-пестрой породы превосходили холмогорских по пожизненному удою и массовой доле жира в молоке в среднем за все лактации - на 3416,5 кг и 0,47 \% соответственно (Р > 0,999). За счет высокой жирномолочности от коров черно-пестрой породы за весь период использования было получено на 6317,7 кг больше молока в пересчете на базисные нормы белка и жира. Но у коров холмогорской породы массовая доля белка в молоке была выше на 0,03 \% (P> 0,999). Срок хозяйственного использования коров двух пород не имел статистических различий и составлял 3,42-3,43 лактации. При анализе влияния возраста первого плодотворного осеменения на продуктивное долголетие коров черно-пестрой породы выявлено, что наибольшим долголетием (3,85 лактации) и пожизненным удоем (21347,8 кг) отличались коровы, чей возраст первого плодотворного осеменения приходился на 16-17 месяцев (таблица 1). Эти животные отличались средним уровнем жирно- и белковомолочности, но за счет самого высокого удоя количество молока, полученного за все лактации, в пересчете на базисные нормы жира и белка у коров этой группы было наибольшим - 27129,5 кг. С увеличением возраста первого осеменения происходит снижение пожизненной продуктивности и срока хозяйственного использования коров. У животных черно-пестрой породы, плодотворно осемененных в 1819 месяцев, отмечен довольно высокий пожизненный удой - 19214,8 кг, но этот показатель ниже, чем у осемененных в 16-17 месяцев, на 2133,0 кг (Р > 0,95). Коровы, осемененные в 18 19 месяцев, отличались самой высокой жирнои белковомолочностью. По пожизненному удою 
в пересчете на базисные нормы они также уступали коровам, осемененным в 16-17 месяцев, этот показатель был ниже на 2342,4 кг (Р <0,95).
Срок использования коров этой группы был меньше по сравнению с осемененными в 1617 месяцев на 0,35 лактации (P >0,95).

Таблица 1 Продуктивное долголетие коров черно-пестрой породы в зависимости от возраста первого плодотворного осеменения

\begin{tabular}{|c|c|c|c|c|c|c|c|}
\hline \multirow{2}{*}{$\begin{array}{c}\text { Возраст } \\
\text { первого плодо- } \\
\text { творного осе- } \\
\text { менения, мес. }\end{array}$} & \multirow[b]{2}{*}{$\begin{array}{l}\text { Количе- } \\
\text { ство ко- } \\
\text { ров, гол. }\end{array}$} & \multirow{2}{*}{$\begin{array}{l}\text { Доля коров } \\
\text { от общего ко- } \\
\text { личества осе- } \\
\text { мененных, \% }\end{array}$} & \multicolumn{4}{|c|}{ Пожизненная продуктивность } & \multirow{2}{*}{$\begin{array}{c}\text { Продолжитель- } \\
\text { ность продуктив- } \\
\text { ного использова- } \\
\text { ния, лактации }\end{array}$} \\
\hline & & & удой, кг & $\begin{array}{c}\text { массовая } \\
\text { доля } \\
\text { жира, \% }\end{array}$ & $\begin{array}{c}\text { массовая } \\
\text { доля } \\
\text { белка, \% }\end{array}$ & $\begin{array}{c}\text { количество молока } \\
\text { в пересчете на базисную } \\
\text { норму жира и белка, кг }\end{array}$ & \\
\hline До 15 & 1275 & 63,4 & $\begin{array}{l}15491,4 \pm \\
305,3^{* * *}\end{array}$ & $\begin{array}{c}4,14 \pm \\
0,007 * * *\end{array}$ & $\begin{array}{c}3,04 \pm \\
0,005 \\
\end{array}$ & $\begin{array}{l}19114,6 \pm \\
376,1^{* * *} \\
\end{array}$ & $\begin{array}{c}3,33 \pm \\
0,05^{* * *} \\
\end{array}$ \\
\hline $16-17$ & 405 & 20,1 & $\begin{array}{c}21347,8 \pm \\
623,8\end{array}$ & $\begin{array}{c}4,25 \pm \\
0,01^{*}\end{array}$ & $\begin{array}{l}3,05 \pm \\
0,003^{*}\end{array}$ & $\begin{array}{c}27129,5 \pm \\
790,3\end{array}$ & $\begin{array}{c}3,85 \pm \\
0,08\end{array}$ \\
\hline $18-19$ & 207 & 10,3 & $\begin{array}{l}19214,8 \pm \\
889,6^{*} \\
\end{array}$ & $\begin{array}{l}4,30 \pm \\
0,02 \\
\end{array}$ & $\begin{array}{c}3,06 \pm \\
0,004\end{array}$ & $\begin{array}{c}24787,1 \pm \\
1124,7 \\
\end{array}$ & $\begin{array}{l}3,50 \pm \\
0,13 *\end{array}$ \\
\hline Старше 20 & 123 & 6,1 & $\begin{array}{l}16623,0 \pm \\
986,4 * * *\end{array}$ & $\begin{array}{c}4,27 \pm \\
0,03 \\
\end{array}$ & $\begin{array}{l}3,05 \pm \\
0,005\end{array}$ & $\begin{array}{l}21224,5 \pm \\
1221,7 * * *\end{array}$ & $\begin{array}{c}3,07 \pm \\
0,12 * * *\end{array}$ \\
\hline Среднее & 2010 & 100,0 & $\begin{array}{c}18169,3 \pm \\
261,3\end{array}$ & $\begin{array}{c}4,23 \pm \\
0,006^{* * *}\end{array}$ & $\begin{array}{l}3,05 \pm \\
0,003 *\end{array}$ & $\begin{array}{l}23063,9 \pm \\
327,2 * * *\end{array}$ & $\begin{array}{c}3,43 \pm \\
0,04 * * *\end{array}$ \\
\hline
\end{tabular}

Примечание: * $\mathrm{P}>0,95 ; * * \mathrm{P}>0,99$; *** $\mathrm{P}>0,999$.

Таблица 2 Продуктивное долголетие коров холмогорской породы

в зависимости от возраста первого плодотворного осеменения

\begin{tabular}{|c|c|c|c|c|c|c|c|}
\hline \multirow{2}{*}{$\begin{array}{c}\text { Возраст } \\
\text { первого плодо- } \\
\text { творного осе- } \\
\text { менения, мес. }\end{array}$} & \multirow[b]{2}{*}{$\begin{array}{l}\text { Количе- } \\
\text { ство ко- } \\
\text { ров, гол. }\end{array}$} & \multirow{2}{*}{$\begin{array}{c}\text { Доля коров } \\
\text { от общего } \\
\text { количества } \\
\text { осеменен- } \\
\text { ных, \% }\end{array}$} & \multicolumn{4}{|c|}{ Пожизненная продуктивность } & \multirow{2}{*}{$\begin{array}{c}\text { Продолжитель- } \\
\text { ность продуктив- } \\
\text { ного использова- } \\
\text { ния, лактации }\end{array}$} \\
\hline & & & удой, кг & $\begin{array}{c}\text { массовая } \\
\text { доля } \\
\text { жира, \% }\end{array}$ & $\begin{array}{c}\text { массовая } \\
\text { доля } \\
\text { белка, \% }\end{array}$ & $\begin{array}{c}\text { количество молока } \\
\text { в пересчете на базисную } \\
\text { норму жира и белка, кг }\end{array}$ & \\
\hline До 15 & 594 & 12,0 & $\begin{array}{c}14262,0 \pm \\
402,4^{*}\end{array}$ & $\begin{array}{c}3,77 \pm \\
0,008 \\
\end{array}$ & $\begin{array}{c}3,09 \pm \\
0,005\end{array}$ & $\begin{array}{c}16288,5 \pm \\
463,0\end{array}$ & $\begin{array}{c}2,92 \pm \\
0,08 * * *\end{array}$ \\
\hline $16-17$ & 1011 & 20,5 & $\begin{array}{c}14421,05 \pm \\
304,2^{*}\end{array}$ & $\begin{array}{c}3,78 \pm \\
0,006\end{array}$ & $\begin{array}{l}3,09 \pm \\
0,003\end{array}$ & $\begin{array}{c}16513,8 \pm \\
347,3\end{array}$ & $\begin{array}{c}3,24 \pm \\
0,06^{* * *}\end{array}$ \\
\hline $18-19$ & 1226 & 24,8 & $\begin{array}{c}14981,9 \pm \\
290,6\end{array}$ & $\begin{array}{c}3,77 \pm \\
0,005\end{array}$ & $\begin{array}{c}3,07 \pm \\
0,003 * * *\end{array}$ & $\begin{array}{c}16999,9 \pm \\
333,9\end{array}$ & $\begin{array}{c}3,55 \pm \\
0,06^{* * *}\end{array}$ \\
\hline Старше 20 & 2105 & 42,7 & $\begin{array}{c}15346,5 \pm \\
217,9\end{array}$ & $\begin{array}{c}3,72 \pm \\
0,004^{* * *}\end{array}$ & $\begin{array}{c}3,07 \pm \\
0,004 * *\end{array}$ & $\begin{array}{c}17182,7 \pm \\
245,2 \\
\end{array}$ & $\begin{array}{c}3,97 \pm \\
0,05 \\
\end{array}$ \\
\hline Среднее & 4936 & 100,0 & $\begin{array}{c}14752,8 \pm \\
141,7\end{array}$ & $\begin{array}{c}3,76 \pm \\
0,002\end{array}$ & $\begin{array}{c}3,08 \pm \\
0,003\end{array}$ & $\begin{array}{c}16746,2 \pm \\
161,2\end{array}$ & $\begin{array}{c}3,42 \pm \\
0,03\end{array}$ \\
\hline
\end{tabular}

Примечание: * $\mathrm{P}>0,95 ; * * \mathrm{P}>0,99$; *** $\mathrm{P}>0,999$.

Срок использования коров черно-пестрой породы, плодотворно осемененных в 20 месяцев и старше, был минимальным - 3,07 лактации. По сравнению с животными, осемененными в 1617 месяцев, этот показатель снизился на 0,78 лактации $(\mathrm{P}>0,999)$. При этом пожизненный удой был меньше на 4724,8 кг (Р > 0,999), в том числе в пересчете на базисные нормы - на 5905,0 кг (Р > 0,999). Массовая доля жира и белка в молоке у животных этой группы была близка к средним значениям.

Раннее осеменение телок черно-пестрой породы (до 15 месяцев) привело как к снижению пожизненной продуктивности, так и уменьшению срока хозяйственного использования. Эти животные имели наименьший пожизненный удой - 15491,4 кг, что на 5856,4 кг или на $27,4 \%$ меньше по сравнению с удоем животных, осеме- ненных в 16-17 месяцев (Р > 0,999). Срок использования коров этой группы был меньше на 0,52 лактации по сравнению с животными, чей возраст первого плодотворного осеменения приходился на 16-17 месяцев. Массовая доля жира и белка в молоке рано осемененных коров черно-пестрой породы была наименьшей - 4,14 и $3,04 \%$ соответственно. В связи с этим пожизненный удой у коров этой группы в пересчете на базисные нормы также был самым низким 19114,6 кг, что меньше, чем у коров, осемененных в 16-17 месяцев, на 8014,9 кг или на 29,5 \% $(\mathrm{P}>0,999)$. Таким образом, оптимальным возрастом первого плодотворного осеменения для животных черно-пестрой породы можно считать 16-17 месяцев, так как при осеменении в эти сроки коровы отличались наибольшим долголетием и самым высоким пожизненным 
удоем, в том числе в пересчете на базисные нормы. Слишком раннее осеменение коров черно-пестрой породы (до 15 месяцев) нецелесообразно, так как животные еще не достигли физиологической зрелости и раннее начало первой лактации не позволило животным полностью раскрыть потенциал молочной продуктивности, привело к излишней нагрузке на организм и сократило срок хозяйственного использования животных. Анализ продуктивного долголетия коров холмогорской породы в зависимости от возраста первого плодотворного осеменения показал, что с увеличением возраста первого осеменения происходит увеличение пожизненного удоя и срока хозяйственного использования животных (таблица 2).

У коров холмогорской породы с более поздним сроком плодотворного осеменения (старше 20 месяцев) был самый высокий пожизненный удой - 15346,5 кг, что на 1084,5 кг больше (P > $0,95)$, чем у животных с ранним сроком осеменения (до 15 месяцев). Срок использования этих животных на 1,05 лактации больше, чем осемененных в возрасте до 15 месяцев, и на 0,73 и 0,42 лактации больше, чем осемененных в возрасте 16-17 и 18-19 месяцев соответственно (P > 0,999).

При повышении возраста первого осеменения до 20 месяцев и старше массовая доля жира в молоке снизилась с 3,77-3,78 \% до 3,72 \% или на 0,05-0,06 \% (P > 0,999). У коров, которые были осеменены в 18 месяцев и старше, массовая доля белка в молоке была на 0,02 \% меньше по сравнению с животными, осемененными в более ранние сроки (P $>0,99)$. С увеличением возраста первого осеменения количество молока, полученного от коров в течение всего периода продуктивного использования, в пересчете на базисные нормы повышалось, но различия недостоверны.

Выводы. Коровы черно-пестрой породы превосходили холмогорских коров по пожиз- ненной продуктивности: по удою - на 3416,5 кг, количеству молока в пересчете на базисные нормы - на 6317,7 кг и массовой доле жира в молоке в среднем за все лактации - на 0,47 \% (Р > 0,999). У коров холмогорской породы массовая доля белка в молоке была выше на 0,03 \% (P > 0,999). Срок хозяйственного использования коров двух пород не имел статистических различий и составлял 3,42-3,43 лактации. Оптимальным возрастом первого плодотворного осеменения для животных черно-пестрой породы можно считать 16-17 месяцев, так как при осеменении в эти сроки коровы отличались наибольшим долголетием (3,85 лактаций) и самым высоким пожизненным удоем $(21347,8$ кг), в том числе в пересчете на базисные нормы (27065,6 кг). Слишком раннее осеменение коров черно-пестрой породы (до 15 месяцев) нецелесообразно, так как не позволяет животному полностью раскрыть потенциал молочной продуктивности, приводит к снижению пожизненного удоя (до 15491,4 кг), жирно- и белковомолочности и сокращает срок хозяйственного использования животных до 3,33 лактаций. Наименьшим долголетием (3,07 лактации) отличались чернопестрые коровы, осемененные в возрасте старше 20 месяцев, их пожизненный удой был меньше, чем у осемененных в 16-17 месяцев, на 4724,8 кг $(\mathrm{P}>0,999)$.

У коров холмогорской породы с увеличением возраста первого осеменения происходит увеличение пожизненного удоя (на 1084,5 кг) $(\mathrm{P}>0,95)$ и срока хозяйственного использования (на 1,05 лактации). Но при осеменении коров в возрасте старше 18 месяцев происходит снижение массовой доли белка в молоке (на 0,06 \%), а при осеменении в возрасте старше 20 месяцев снижение массовой доли жира - на 0,02 \% (P > 0,999). Поэтому повышение пожизненного удоя в пересчете на базисные нормы в связи с увеличением возраста первого осеменения не имеет достоверных различий.

\section{Библиографический список}

1. Батанов, С.Д. Продуктивное долголетие и воспроизводительные качества коров чернопестрой породы отечественной и голландской селекции [Текст] / С.Д. Батанов, М.В. Воторопина, Е.И. Шкарупа // Зоотехния. 2011. № 3. C. 2-4.

2. Бычкова, В.А. Влияние мастита на состав молока и пригодность для переработки [Текст] / В.А. Бычкова, Ю.Г. Мануилова // Научное обеспечение инновационного развития
АПК: материалы Всероссийской научно-практической конференции, посвященной 90-летию государственности Удмуртии. Ижевск: Ижевская ГСХА, 2010. С. 113-117.

3. Вильвер, Д.С. Молочная продуктивность коров чёрно-пёстрой породы разного возраста и её связь с живой массой тёлок при первом осеменении [Текст] / Д.С. Вильвер // Известия Оренбургского государственного аграрного университета. 2016. № 3 (59). С. 128-130. 
4. Дмитриева, В.И. Продуктивное долголетие коров и влияние на него ряда факторов [Текст] / В.И. Дмитриева, Д.Н. Кольцов, М.Е. Гонтов, В.К. Чернушенко // Зоотехния. 2009. № 7. С. 18-20.

5. Ижболдина, С.Н. Современные технологии производства молока, способствующие повышению продуктивности коров и их долголетию [Текст]: монография / С.Н. Ижболдина, М.Р. Кудрин. Ижевская ГСХА, 2015. 162 с.

6. Казанцева, Е. С. Влияние генотипических и паратипических факторов на продуктивное долголетие коров черно-пестрой породы Зауралья [Текст]: автореф. дис. ... канд. с.-х. наук: 06.02.10 / Е.С. Казанцева. Курган, 2015. 20 с.

7. Кахикало, В.Г. Влияние возраста первого отела коров черно-пестрой породы на показатели молочной продуктивности [Текст] / В.Г. Кахикало, О.В. Назарченко, Л.А. Шабунин, Н.А. Шабунина // Главный зоотехник. 2015. № 5-6. С. 11-15.

8. Кузьмина, Н.В. Влияние паратипических факторов на продуктивное долголетие коров черно-пестрой породы [Текст] / Н.В. Кузьмина, Д.Н. Кольцов // Национальная ассоциация ученых. 2015. № 9-3 (14). С. 148-151.

9. Любимов, А.И. Взаимосвязь воспроизводительных качеств с продуктивным долголетием коров чёрно-пёстрой породы [Текст] / А.И. Любимов, В.М. Юдин, А.С. Чукавин // Роль молодых учёных-инноваторов в решении задач по ускоренному импортозамещению сельскохозяйственной продукции: материалы Всерос. науч.-практ. конф. 27-29 октября 2015 года, г. Ижевск. Ижевск: Ижевская ГСХА, 2015. C. $68-72$.

10. Мударисов, Р.М. Факторы, влияющие на молочную продуктивность коров черно-пестрой породы немецкой селекции [Электронный ресурс] / Р.М. Мударисов, Г.Р. Ахметзянова // Рос- сийский электронный научный журнал. 2013. № 5. C. 182-189.

11. Рахимкулова, Г.Р. Продуктивное долголетие коров голштинской породы в условиях ГУСП совхоз «Алексеевский» [Текст] / Г.Р. Рахимкулова, Р.М. Мударисов // Современные основы рационализации технологии воспроизводства сельскохозяйственных животных в условиях индустриальной системы производства в АПК. Материалы всероссийской молодежной научной школы в рамках Федеральной целевой программы «Научные и научно-педагогические кадры инновационной России» на 2009-2013 годы (Уфа, Россия, 11-14 сентября 2012 г.). Уфа: Башкирский ГАУ, 2012. С. 147-149.

12. Сарайкин, В.А. Молочное скотоводство: проблемы роста и развития [Текст] / В.А. Сарайкин // Экономика с.-х. и перерабатывающих предприятий. 2015. № 11. С. 26-29.

13. Шарафутдинов, Г.С. Молочная продуктивность первотелок разной селекции в зависимости от возраста первого отела [Текст] / Г.С. Шарафутдинов, Р.Р. Шайдуллин, С.В. Тюлькин, И.И. Хатыпов // Вестник Казанского государственного аграрного университета. 2008. № 4 (10). C. 119-122.

14. Daniel Z. Caraviello Length of Productive Life of High Producing Cows. J. Dairy Updates Reproduction and Genetics. 2009. № 612. Pp. 1-8.

15. Hansen L. B., Cole J. B., Marx G. D. Body size of lactating dairy cows: results of divergent selection for over 30 years. URL: Daniel Z. Caraviello Length of Productive Life of High Producing Cows. J. Dairy Updates Reproduction and Genetics. 2009. No. 612.

16. Schuster Jesse Cantin, Richard, Mason Steve, Kelton F. David, Barkema W. Herman, Orsel Karin. Measures of Longevity in Canadian Dairy Cattle. WCDS Advances in Dairy Technology (2018). Volume 30, Abstract, page 387.

\section{Сведения об авторах}

1. Русских Татьяна Александровна, аспирант кафедры технологии переработки продукции животноводства, ФГБОУ ВО Ижевская ГСХА, г. Ижевск, ул. Студенческая, д. 11, 426000, e-mail: aleksandrovna0301@mail.ru.

2. Бычкова Вероника Анатольевна, кандидат сельскохозяйственных наук, доцент кафедры технологии переработки продукции животноводства, ФГБОУ ВО Ижевская ГСХА, г. Ижевск, ул. Студенческая, д. 11, 426000, e-mail: barsik72@gmail.com.

В статье приведены результаты анализа влияния возраста первого плодотворного осеменения на продуктивное долголетие коров чернопестрой и холмогорской пород в Удмуртской Республике. Срок хозяйственного использова- ния коров двух пород не имел статистических различий и составлял 3,42-3,43 лактации. Коровы черно-пестрой породы превосходили холмогорских коров по пожизненному удою (на 3416,5 кг), содержанию жира в молоке (на 
$0,47 \%$ и и количеству молока в пересчете на базисные нормы (на 6317,7 кг; Р > 0,999). Оптимальным возрастом первого осеменения для животных черно-пестрой породы можно считать 16-17 месяцев, так как при осеменении в эти сроки коровы отличались наибольшим долголетием $(3,85$ лактаций) и самым высоким пожизненным удоем (21347,8 кг), в том числе в пересчете на базисные нормы (27065,6 кг). Слишком раннее осеменение коров черно-пестрой породы (до 15 месяцев) нецелесообразно, так как это приводит к снижению пожизненного удоя (до 15491,4 кг), жирно- и белковомолочности и сокращает срок хозяйственного использования животных до 3,33 лактаций. Наименьшим долголетием (3,07 лактации) отличались чернопестрые коровы, осемененные в возрасте старше 20 месяцев. У коров холмогорской породы с увеличением возраста первого осеменения происходит увеличение пожизненного удоя (на $1084,5$ кг $(\mathrm{P}>0,95))$ и срока хозяйственного использования (на 1,05 лактации (Р > 0,999)). Но вследствие снижения в молоке массовой доли жира (на 0,06 \% (P> 0,999)) и белка (на 0,02\% $(\mathrm{P}>0,999))$ повышение пожизненного удоя в пересчете на базисные нормы в связи с увеличением возраста первого осеменения не имеет достоверных различий.

\section{T. Russkikh, V. Bychkova}

\section{INFLUENCE OF THE AGE AT THE FIRST INSEMINATION ON THE PRODUCTIVE LONGEVITY OF BLACK AND WHITE AND KHOLMOGORY COWS}

Key words: black-and-white breed; Kholmogory breed; age of the first fruitful insemination; duration of productive use; lifelong productivity.

\section{Authors' personal details}

1. Russkikh Tatyana, Post-graduate student of the department of Technology of processing animal products, Federal State Budgetary Educational Institution of Higher Education «Izhevsk State Agricultural Academy», Udmurt Republic, Izhevsk, Student St., 11, e-mail: aleksandrov-na0301@mail.ru.

2. Bychkova Veronika, Candidate of Agricultural Sciences, Associate Professor of the Department of Technology for the Reproduction of Livestock Products, Federal State Budgetary Educational Institution of Higher Education «Izhevsk State Agricultural Academy», Udmurt Republic, Izhevsk, Student St., 11, e-mail: barsik72@gmail.com.

The influence of the age at the first fruitful insemination on the productive longevity of the blackand-white and Kholmogory cows in Udmurt republic was analysed. The study results are presented in the paper. The economic use period of the study cows did not have statistical differences and lasted 3,42-3,43 lactation periods. Black-and-white cows exceeded Kholmogory cows in the lifetime milk yield (by $3416,5 \mathrm{~kg}$ ), fat content in milk (by $0,47 \%$ ) and milk amount in terms of basic standards (by $6317,7 \mathrm{~kg})(\mathrm{P}>0,999)$. The optimal age for the first insemination of black-and-white cows can be considered 16-17 months, since insemination at the specified age ensures highest longevity in cows (3,85 lactations) and the highest lifetime milk yield indices $(21347,8 \mathrm{~kg})$, also expressed in terms of basic standards $(27065,6 \mathrm{~kg})$. Too early insemination of the black-and-white cows (up to 15 months) is not recommended, as it results in the decreased lifetime milk yields (up to $15491,4 \mathrm{~kg}$ ), fat and protein content and shortens the economic use period of the animals up to 3,33 lactation periods. The lowest longevity (3,07 lactation periods) was observed in the black-and-white cows inseminated at the age of more than 20 months. The Kholmogory cows demonstrated an increase in lifetime milk yields $(1084,5 \mathrm{~kg}(\mathrm{P}>0,95))$ and the economic use period $(1,05$ lactation period $(\mathrm{P}>0,999))$ when the age of the first insemination was increased. However, as the fat mass ratio in milk decreased (by $0,06 \%$ $(\mathrm{P}>0,999))$ and the protein mass ratio in milk fell (by $0,02 \%(\mathrm{P}>0,999))$, the increase in lifetime milk yield in terms of basic standards resulted from the increase in the age of the first insemination has no significant differences.

(C) Русских Т.А., Бычкова В.А. 
УДК 637.1(470.620)

DOI: 10.31563/1684-7628-2019-51-3-64-69

B.А. Тараненко, С.Н. Косников

\section{ОЦЕНКА И ПЕРСПЕКТИВЫ РАЗВИТИЯ МОЛОЧНОЙ ПРОМЫШЛЕННОСТИ В КРАСНОДАРСКОМ КРАЕ}

\section{Ключевые слова: молочная продукция; производство; жсивотноводство; завод; хозяйство; транспортировка; модульный цех.}

На рынке животноводческой отрасли отрицательными факторами эффективного развития являются: большая вероятность застоя производства сырья; высокая доля фальсификации молочной продукции до $10 \%$; снижение потребления некоторых молочных продуктов вследствие сокращения доходов населения и подорожания товаров; высокие затраты на транспортировку молочной продукции. Эти факторы увеличивают вероятность образования и наступления коммерческих и производственных рисков в работе предприятий молочной сферы. Именно поэтому всего на $5 \%$ используется потенциал этой сферы, так как транспортировка молочной продукции предполагает определенные затраты, которые многие предприятия могут не выдержать. Требуется максимальное внедрение результатов как зоотехнической и ветеринарной наук, так и применение различных передовых форм, технологии управления, методов, техники.

Чтобы сократить затраты на транспортировку молочной продукции, мы предлагаем постройку мини-завода на предприятиях. Предприятия, выпускающие мини-заводы по переработке молочной продукции в конечный товар, успешно функционируют уже более пяти лет. Мы предполагаем, что организация переработки с последующей продажей производимой молочной продукции даст возможность любому хозяйству повысить финансовую независимость организации и рентабельность молочного производства.

Краснодарский край является важнейшим поставщиком продуктов животноводства: в валовом производстве сельскохозяйственной продукции края удельный вес животноводства составляет $25 \%$. В Российской Федерации Краснодарский край занимает 3-е место по производству скота и птицы на убой в живом весе, а также 3-е и 4-е места по производству яиц и молока соответственно. Данные таблицы 1 подтверждают тот факт, что за последние 5 лет произошло повышение отдельных показателей, характеризующих отрасль животноводства Краснодарского края. Производство молока увеличилось на
61,5 тыс. т (4,7 \%). Надой молока на одну корову увеличился на 789 кг. Однако поголовье крупного рогатого скота по краю сократилось на 20 тыс. гол. (3,6 \%). В Краснодарском крае основными потребителями сырого молока являются молочные заводы. По статистическим данным перерабатывающей промышленности Краснодарского края, загрузка мощностей молочных заводов не превышает $45 \%$, хотя потребляют они более $90 \%$ молока. Уменьшение объемов реализации сырого молока приводит к сильной конкурентной борьбе на сырьевом рынке в условиях повышенной концентрации перерабатывающих предприятий в крае. Переработкой молока в Краснодарском крае заняты около 100 организаций, из них 20 крупных и средних.

В сфере молочного производства комбинаты и заводы Краснодарского края производят большой ассортимент молочных продуктов. Многие предприятия задействованы в производстве цельномолочной и кисломолочной продукции, существуют также специализированные сыродельные производства, например, сгущенное молоко и мороженое выпускает Кореновский молочный консервный комбинат. В крае в настоящий момент перерабатывается около 9 тыс. т молока, 2/3 которых реализуются жителям и гостям Краснодарского края. Одним из основных предприятий, занимающихся изготовлением и разработкой модульных цехов, предназначенных для переработки молока, является Колакс. Поддержка заказчикам оказывается на всех этапах организации молочного производства.

Из Российских молочных комплексов лучшим сейчас является модульный молочный цех, содержащий в себе полный комплект нормативно-разрешительной документации и уникальные технические решения (рисунок 1). Стоимость комплекса составит 12,6 млн руб. При надлежащем его использовании срок эксплуатации оборудования составит 12-13 лет. В стоимость проекта включены все необходимые для монтажа и запуска материалы. Комплексу также 
предоставляется набор устройств, которые позволяют каждый день контролировать в партиях качество кефира, сметаны и молока, а также мо- ющие средства, набор заквасок и любые другие материалы, требующиеся для работы (в расчете на 30 дней).

Таблица 1 Показатели, характеризующие отрасль животноводства Краснодарского края по всем категориям

\begin{tabular}{|l|c|c|c|c|c|c|c|}
\hline \multicolumn{1}{|c|}{ Показатель } & 2013 г. & 2014 г. & 2015 г. & 2016 г. & 2017 г. & $\begin{array}{c}2017 \text { г. к } \\
2013 \text { г., \% }\end{array}$ \\
\hline \multicolumn{2}{|c|}{ Поголовье, тыс. гол. } \\
\hline Крупного рогатого скота & 563 & 543 & 539 & 546 & 543 & 96,4 \\
\hline в том числе коровы & 225 & 218 & 216 & 215 & 213 & 94,7 \\
\hline Свиньи, тыс. гол. & 289 & 334 & 434 & 367 & 410 & 141,9 \\
\hline Овцы и козы, тыс. гол. & 180 & 197 & 208 & 227 & 224 & 124,4 \\
\hline Лошади, тыс. гол. & 13 & 12 & 11 & 11 & 10 & 76,9 \\
\hline Птица, млн гол. & 24 & 23 & 24 & 26 & 27 & 112,5 \\
\hline & \multicolumn{2}{|c|}{ Производство, тыс. т } & \multicolumn{5}{|c|}{} \\
\hline Скот и птица на убой (в живом весе) & 465,2 & 468,8 & 495,7 & 500,1 & 512,6 & 110,2 \\
\hline Скот и птица на убой в убойном весе) из него: & 336,3 & 339,7 & 361,8 & 364,3 & 373,1 & 110,9 \\
\hline крупный рогатый скот & 68,3 & 66,3 & 63,3 & 64,7 & 67,7 & 99,1 \\
\hline свиньи & 42,2 & 43,4 & 56,1 & 64,9 & 54,7 & 129,6 \\
\hline овцы и козы & 1,3 & 1,5 & 1,6 & 1,7 & 1,7 & 130,8 \\
\hline птица & 222,8 & 226,8 & 239,0 & 231,2 & 247,0 & 110,9 \\
\hline Молоко & 1319,4 & 1302,1 & 1327,6 & 1357,0 & 1380,9 & 104,7 \\
\hline Яйца, млн шт. & 1484,6 & 1399,3 & 1543,2 & 1722,4 & 1785,9 & 120,3 \\
\hline Шерсть, т & 251 & 286 & 306 & 325 & 355 & 141,4 \\
\hline Мед (вынутый), т & 2353 & 2347 & 2370 & 2834 & 2828 & 120,2 \\
\hline
\end{tabular}

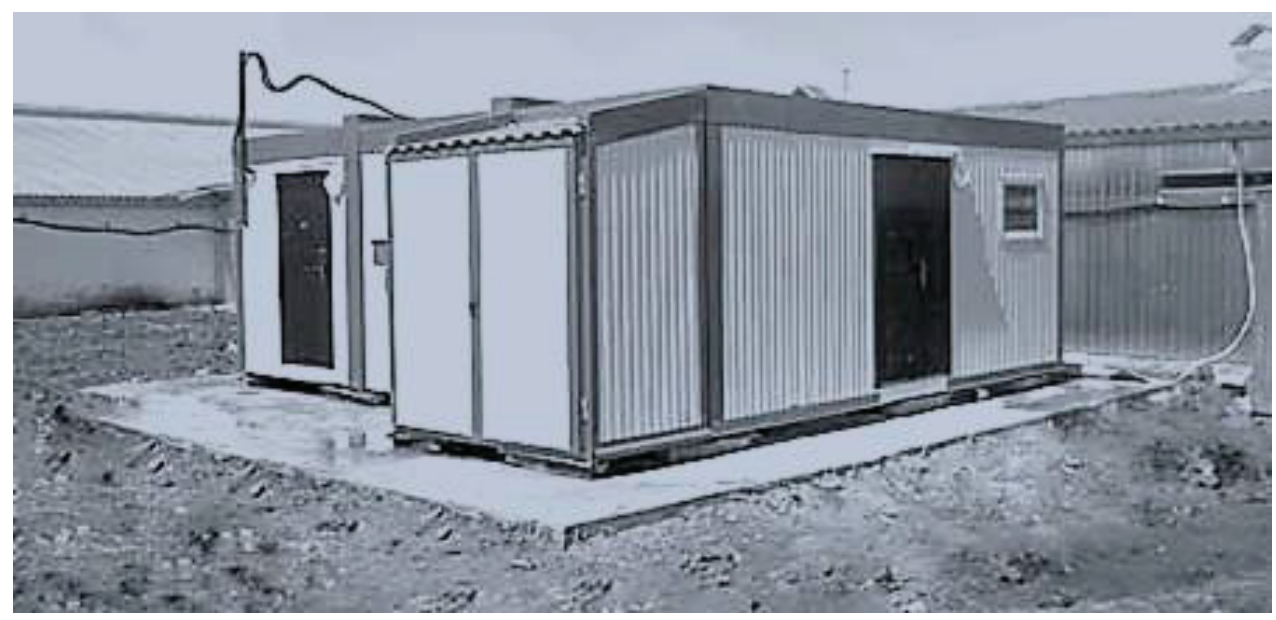

Рисунок 1

Модульные цеха молочного мини-завода

Продолжительность монтажных работ и запуска комплекса, где планируется установка, составляет от одного до пяти рабочих дней. По предварительным подсчетам, подготовка площадки в 2018 г. может обойтись в 560 тысяч рублей. Стоимость запуска оборудования, технологической пробы, обучения персонала и шефмонтажа составит $10 \%$ от стоимости оборудования, т. е. хозяйству обойдется в 1,4 млн руб. Отразим технические характеристики модуля производительностью на 10000 литров в смену в таблице 2 .

В производственном цехе переработка молока проходит следующий путь: из всего посту- пившего в цех молока 40 \% идет на нормализацию, а 60 \% - на сепарирование, все поступившее молоко обязательно пастеризуется. После пастеризации и сепарирования 88 \% является обезжиренным молоком (обрат) и $12 \%$ - сливками (рисунок 2).

Мы планируем запуск комплекса в режиме двух восьмичасовых смен, работающих ежедневно, без выходных. Необходимость мини-завода в сыром молоке составит приблизительно 36500 центнеров в год, учитывая количество рабочих дней и номинальную производительность. В комплекс молочного производства уже 
включена стоимость упаковочной линии, которая представляет собой оборудование в виде настольного комплекса для автоматической герметической упаковки в пакеты вместимостью
0,25, 0,5 и 1,0 л жидких продуктов. Непрерывным потоком поступает охлажденное и стерилизованное молоко после стерилизации пакетов в бумажную трубу.

Таблица 2 Технические характеристики модуля на 10000 литров в смену

\begin{tabular}{|c|c|c|}
\hline \multicolumn{2}{|r|}{ Параметр } & Значение \\
\hline \multirow{4}{*}{ Водоснабжение } & - температура подаваемой воды, ${ }^{\circ} \mathrm{C}$ & не более 7 \\
\hline & - давление подаваемой воды, Атм & от 0,6 до 2,1 \\
\hline & - качество подаваемой воды & В соответствии с ГОСТ 2874-82 \\
\hline & - расход воды, м³/час & 5 \\
\hline Канализация & - скорость отвода стоков, $\mathrm{M}^{3} /$ час & 2,8 \\
\hline \multirow{4}{*}{$\begin{array}{l}\text { Климатические условия } \\
\text { эксплуатации }\end{array}$} & 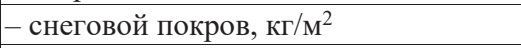 & 250 \\
\hline & - сейсмичность - не более, баллов & 7 \\
\hline & - ветровой напор, кг/м² & 45 \\
\hline & - температура окружающей среды, ${ }^{\circ} \mathrm{C}$ & от -25 до +30 \\
\hline \multirow{4}{*}{ Электроснабжение } & - питающее напряжение, В & $380 / 220$ \\
\hline & - электрическая сеть 5 проводная & L1, L2, L3, N, PE \\
\hline & - частота питающего напряжения, Гц & 50 \\
\hline & - установленная мощность, кВт & 500 \\
\hline Вес, кг & & 60000 \\
\hline
\end{tabular}

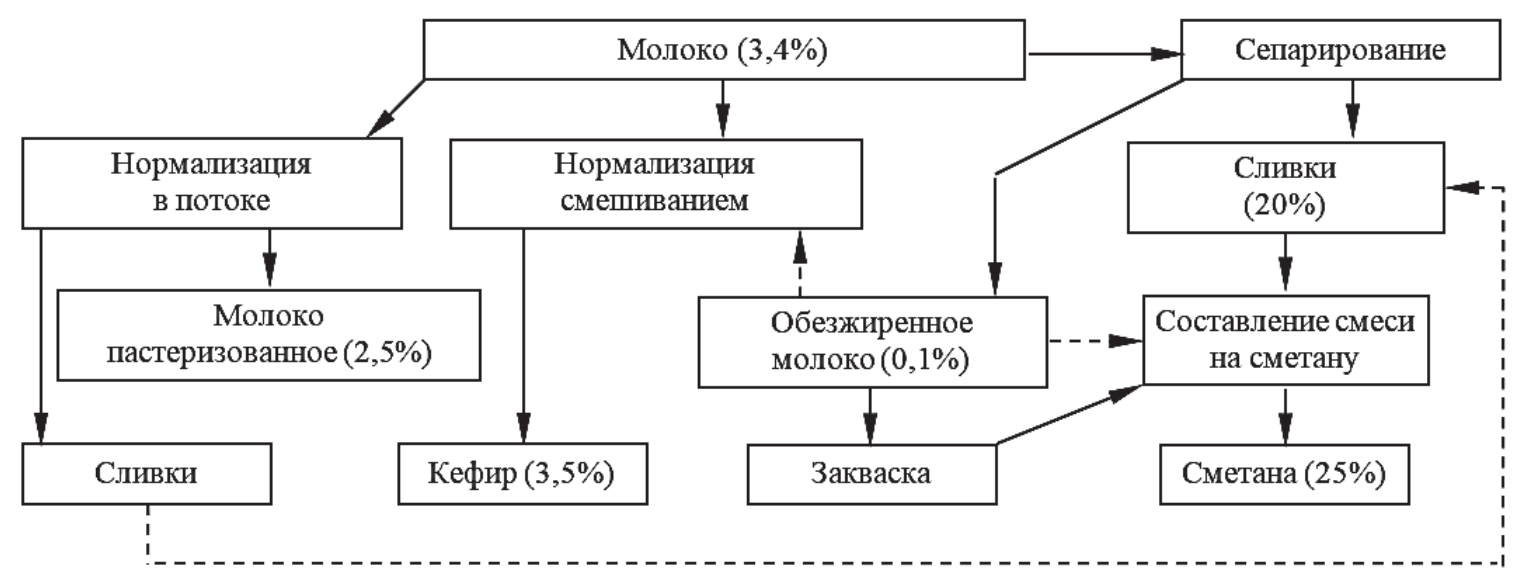

Рисунок 2

Схема распределения сырья

Таблица 3 Расчет затрат на производство годового объема молочной продукции, тыс. руб.

\begin{tabular}{|l|c|}
\hline Наименование затрат & Сумма \\
\hline Сырье (молоко жирностью 3,4 \%) & 45154,0 \\
\hline Амортизация & 930,8 \\
\hline Фильтрованная вода & 368,9 \\
\hline Материал & 1230,0 \\
\hline Оплата труда с начислениями & 4470,2 \\
\hline Упаковка & 3000,0 \\
\hline Электроэнергия & 5590,6 \\
\hline Прочие затраты & 400,0 \\
\hline Итого & 61244,5 \\
\hline
\end{tabular}

В таблице 3 приведен расчет затрат на производство годового объема молочной продукции.

В расчетах средние цены ниже рыночных на сметану и пастеризованное молоко, так как планируется создание благоприятных условий для осуществления ценовой конкуренции при осво- ении новых инновационных технологий ведения бизнеса.

Использование новейших технологических приемов по переработке молочной продукции позволит сельскохозяйственному производителю увеличить уровень рентабельность производства 
и реализации до 80,3 \% (таблица 4), при этом срок окупаемости инвестиции составит всего 0,4 года.

Для более наглядного обоснования эффективности внедрения мини-завода по перера- ботке молока в молочную продукцию представим сравнительную характеристику проектов по реализации молока в виде сырья и продуктов переработки (таблица 5).

Таблица 4 Расчет окупаемости молочного комплекса с объемом переработки молока 10000 кг в смену

\begin{tabular}{|c|c|c|}
\hline & Показатель & Значение \\
\hline \multicolumn{2}{|c|}{ Выручка от реализации продукции за год, тыс. руб. - всего } & 87873,5 \\
\hline \multirow{3}{*}{ в том числе: } & кефира & 15796,4 \\
\hline & сметаны & 12840,7 \\
\hline & молока пастеризованного & 59236,4 \\
\hline \multirow{3}{*}{$\begin{array}{l}\text { Годовой объем } \\
\text { производства, ц: }\end{array}$} & кефира $(3,5 \%)$ & 7898,2 \\
\hline & сметаны (25\%) & 1975,5 \\
\hline & молока пастеризованного (2,5%) & 29618,2 \\
\hline \multicolumn{2}{|c|}{ Срок окупаемости инвестиционных вложений, лет } & 0,4 \\
\hline \multirow{3}{*}{$\begin{array}{l}\text { Цена реализации } 1 \text { кг } \\
\text { продукции, руб/кг: }\end{array}$} & кефира & 30,0 \\
\hline & сметаны & 165,0 \\
\hline & молока пастеризованного & 40,0 \\
\hline \multicolumn{2}{|c|}{ Инвестиционные вложения, тыс. руб. - всего, } & 14140,0 \\
\hline \multirow{3}{*}{ в том числе: } & стоимость площадки & 540,0 \\
\hline & стоимость шефмонтажа & 1200,0 \\
\hline & стоимость оборудования & 12400,0 \\
\hline \multicolumn{2}{|l|}{ Рентабельность, \% } & 80,4 \\
\hline \multicolumn{2}{|l|}{ Прибыль, тыс. руб. } & 39129,0 \\
\hline \multicolumn{2}{|c|}{ Производственные затраты за год, тыс. руб. } & 48744,5 \\
\hline
\end{tabular}

Таблица 5 Сравнение эффективности от реализации молока в сыром виде и продуктов его переработки на проектном молочном комплексе

\begin{tabular}{|c|c|c|c|c|}
\hline \multicolumn{2}{|c|}{ Показатель } & $\begin{array}{c}\text { Реализация } \\
\text { молока в виде }\end{array}$ & $\begin{array}{c}\text { Реализация } \\
\text { продуктов переработки }\end{array}$ & $\begin{array}{c}\text { Изменение, } \\
+/-\end{array}$ \\
\hline \multirow{4}{*}{$\begin{array}{l}\text { Годовой объем реализуемой } \\
\text { продукции, т: }\end{array}$} & молока сырого (3,4%) & 39461,0 & - & - \\
\hline & кефира $(3,5 \%)$ & - & 7898,2 & - \\
\hline & сметаны полужирной (25%) & - & 1975,5 & - \\
\hline & молока пастеризованного (2,5%) & - & 29618,2 & - \\
\hline \multicolumn{2}{|l|}{ Объем переработки, т } & 39461,0 & 39461,0 & - \\
\hline \multicolumn{2}{|c|}{ Производственные затраты за год, тыс. руб. } & 35154,0 & 48744,5 & $+13590,5$ \\
\hline \multirow{4}{*}{$\begin{array}{l}\text { Цена реализации } 1 \text { кг } \\
\text { продукции, руб./кг: }\end{array}$} & кефира $(3,5 \%)$ & 34,9 & - & - \\
\hline & молока сырого (3,4%) & - & 30,0 & - \\
\hline & сметаны полужирной (25 \%) & - & 165,0 & - \\
\hline & молока пастеризованного (2,5%) & - & 40,0 & - \\
\hline \multicolumn{2}{|l|}{ Рентабельность, \% } & 60,3 & 80,3 & $+20,0$ \\
\hline \multicolumn{2}{|c|}{ Выручка от реализации продукции за год, тыс. руб. } & 58985,0 & 87873,5 & $+28888,5$ \\
\hline \multicolumn{2}{|c|}{ Прибыль, тыс. руб. } & 23831,0 & 39129,0 & $+15298,0$ \\
\hline
\end{tabular}

Из данных таблицы 5 видно, что при относительно небольших капиталовложениях, необходимых для возведения мини-завода по переработке молока, прибыль организации увеличится на $64 \%$, а рентабельность - на $20 \%$.

Таким образом, создание мини-заводов по переработке молочной продукции является полностью рациональным, а главное, прибыльным мероприятием для предприятия с любым уровнем дохода и способствует не только снижению затрат на переработку, упаковку молочной продукции, но и повышению конкурентоспособности молочной промышленности, что дает реальную возможность для нормального функционирования отрасли животноводства Краснодарского края. 


\section{Библиографический список}

1. Белкина, Е.Н. Мотивы и стимулы модернизации животноводческих предприятий [Текст] / Е.Н. Белкина. М.: Эксмо, 2014. 156 с.

2. Горлов, И.Ф. Интенсификация кормопроизводства для молочного скотоводства на основе применения адаптивных и высокоэффективных технологий возделывания кормовых культур [Текст] / И.Ф. Горлов, О.П. Шахбазова, В.В. Губарева // Вестник Алтайского государственного университета. 2016. № 11 (121). С. 98-104.

3. Горохова, С.С. Об определении экономической безопасности в контексте новой стратегии ее обеспечения в Российской Федерации
[Текст] / С.С. Горохова. М.: Рос. юстиция, 2018. $144 \mathrm{c}$.

4. Самуэльсон, П.Э. Экономикс [Текст] / П.Э. Самуэльсон. М.: Вильямс, 2018. 132 с.

5. Наркевич, И.А. Управление и экономика фармации [Текст] / И.А. Наркевич. М.: ГЭОТАРМедиа, 2018. 928 с.

6. Лысенко, Е.Г. Экономика сельского хозяйства [Текст] / Е.Г. Лысенко. М.: Лань, 2015. $356 \mathrm{c}$.

7. Мухопад, В.И. Экономика и коммерциализация интеллектуальной собственности [Текст] / В.И. Мухопад. М.: Магистр, 2018. 576 с.

\section{Сведения об авторах}

1. Тараненко Валентина Александровна, студентка 4 курса экономического факультета, ФГБОУ ВО «Кубанский государственный аграрный университет имени И.Т. Трубилина», 350044, г. Краснодар, ул. Калинина, 13, e-mail: valentina97@bk.ru.

2. Косников Сергей Николаевич, кандидат экономических наук, доцент, ФГБОУ ВО «Кубанский государственный аграрный университет имени И.Т. Трубилина», 350044, г. Краснодар, ул. Калинина, 13, e-mail: sn_03@rambler.ru.

Краснодарский край является ключевым поставщиком животноводческой продукции. Удельный вес отрасли животноводства составляет $26 \%$ в валовом производстве сельскохозяйственной продукции Краснодарского края. Отрасль молочного производства должна максимально использовать достижения как ветеринарной и зоотехнической наук, так и различных передовых форм, методов, техники, технологии управления. Высокие затраты, связанные с транспортировкой молочной продукции, являются главным фактором, препятствующим высокой эффективности указанной отрасли. Выходом из сложившейся ситуации может быть создание ав- тономных модульных цехов в хозяйстве. При правильном использовании модульного цеха срок эксплуатации оборудования составит 12-13 лет. В комплект модуля входит необходимое для запуска и монтажа оборудование, которое включено в стоимость проекта. От хозяйства потребуются сравнительно небольшие капиталовложения для внедрения мини-завода по переработке молока. Преимущество данного проекта заключается в том, что оно подойдет для предприятий с различным уровнем дохода. Реализация этого проекта позволит снизить затраты на переработку и упаковку молочной продукции и осуществить её активную реализацию на рынке.

V. Taranenko, S. Kosnikov

\section{DAIRY INDUSTRY IN KRASNODAR TERRITORY: ASSESSMENT AND DEVELOPMENT PROSPECTS}

Key words: dairy products; production; livestock breeding; factory; farm; transportation; modular workshop.

\section{Authors' personal details}

1. Taranenko Valentina, 4th year student of the Economics Faculty, Federal State Budgetary Educational Institution of Higher Education «Kuban State Agrarian University named after I.T. Trubilin», Krasnodar, Kalinina St., 13, e-mail: valentina97@bk.ru.

2. Kosnikov Sergey, Candidate of Economic Sciences, Associate Professor, Federal State Budgetary Educational Institution of Higher Education «Kuban State Agrarian University named after I.T. Trubilin», Krasnodar, Kalinina St., 13, e-mail: sn_03@rambler.ru. 
Krasnodar territory is a key supplier of livestock products. The share of the livestock industry is $26 \%$ of the gross agricultural production of Krasnodar Territory. The dairy industry should maximize the achievements of both veterinary and animal sciences, as well as of advanced forms, methods, techniques and management technology. The main factor hindering the high efficiency of the industry is the high costs associated with transporting dairy products. The problem can be solved through developing autonomous modular workshops on dairy

(C) Тараненко В.А., Косников С.Н. farms. The proper use of the workshop can lengthen the service life of the equipment up to 12 to 13 years. The modular workshop contains the necessary equipment for launch and installation of facilities, which is included in the project cost. The farm will need relatively little investment to introduce a mini-plant for milk processing. The advantage of this project is that it is suitable for enterprises with different levels of income. The project implementation will reduce the milk processing and packaging costs and actively place dairy products on the market.

УДК 636.2:636.082.12

DOI: $10.31563 / 1684-7628-2019-51-3-69-74$

М.Б. Улимбашев

\section{ТИПЫ ТЕЛОСЛОЖЕНИЯ ГОЛШТИНСКОГО СКОТА В ЗАВИСИМОСТИ ОТ УДЕЛЬНО-МАССОВОГО КОЭФФИЦИЕНТА}

\section{Ключевые слова: голштинская порода; коровы; удельно-массовый коэффициент; тип консти- туции; продуктивность.}

Введение. Селекция молочного скота по показателям экстерьера необходима и является важным фактором в повышении конкурентоспособности отечественного молочного скотоводства $[1,2,10,11]$. Создание высокопродуктивных молочных стад наряду с селекцией по признакам молочной продуктивности обусловлено вниманием селекционеров к экстерьерной оценке животных, так как для получения большей прибыли необходимо вести селекцию на выносливость и технологичность $[3,12]$. На основе глазомерной оценки, измерения животных и использования метода модельных отклонений [4] с вычислением индивидуальных индексов Г.Ф. Пустотиной [5] выявлено восемь типов конституции: нежно-плотный лептосомный $(15,4 \%)$, нежно-рыхлый лептосомный $(10,2 \%)$, грубо-плотный лептосомный $(9,0$ \%) грубо-рыхлый лептосомный (17,6 \%), нежно-плотный эйрисомный $(13,8 \%)$, нежно-рыхлый эйрисомный $(12,2 \%)$, грубо-плотный эйрисомный $(10,6 \%)$, грубо-рыхлый эйрисомный $(11,2 \%)$, различающихся между собой по развитию статей и продуктивным качествам. С точки зрения хозяйственной полезности, наиболее желательными являются животные крепкой конституции всех ее сочетаний, так как они достигают высокой живой массы во взрослом состоянии и производят на 1 кг живой массы от 7,2 до 8,1 кг молока с массовой долей жира в молоке 3,72-3,73 \%. На всем протяжении существования зоотехнической науки животные оценивались по внешним формам с целью установления более продуктивного скота и его использования для нужд человечества. Применялись с этой целью разные методы оценки, которые совершенствовались селекционерами, с течением времени уточнялись определенные методики, создавались новые критерии оценки. Процесс определения типа телосложения животного вполне логичен в плане установления уровня его продуктивных качеств, получения продукции с минимальными затратами труда и средств, а также выявления особей с длительным сроком хозяйственного использования, что отражено в ряде исследований [6-8].

В связи с этим нами сделана попытка усовершенствования методических подходов к выявлению типа конституции коров молочного направления продуктивности, в частности голштинской породы, наиболее распространенной в нашей стране, что представляет для селекционеров не только определенный теоретический, но и большой практический интерес.

Цель исследований заключалась в распределении коров голштинской породы черно-пестрой масти по типу конституции на основе предлагаемого способа определения удельно-массового коэффициента (УМК) и выявления обильномолочного типа коров. 
Материалы и методы исследований. Исследования проводили в КФХ «Балагов», расположенном в Баксанском районе Кабардино-Балкарской Республики. Экстерьерно-конституциональные типы коров голштинской породы черно-пестрой масти устанавливали по удельномассовому коэффициенту (УМК) по предложенной нами формуле:

$$
У M K=\frac{2500 \times M}{\Gamma_{2} \times K_{\partial} \times\left(W_{2}+W_{m}\right)},
$$

где $M$ - живая масса коровы, кг; $\Gamma_{2}$ - глубина груди, см; $W_{2}$ - ширина груди, см; $W_{m}$ - ширина в тазобедренных сочленениях, см; $K_{\partial}-$ косая длина туловища (мерной палкой), см.

Распределение коров на типы телосложения проводили по величине УМК: рыхлый $(1,36$ и менее), промежуточный $(1,37-1,54)$ и плотный (1,55 и более). Исследования проводили на 136 полновозрастных коровах, у которых брали соответствующие промеры тела с целью установления УМК, принадлежности к тому или иному типу телосложения, а также определения живой массы. Животные находились на круглогодовом однотипном кормлении, обеспечивающем уровень продуктивности стада в пределах 7000 кг молока в год. Об обменных процессах в организме подопытных животных судили по концентрации в крови общего белка, гемоглобина, эритроцитов и лейкоцитов по общепринятым в клинической практике методикам. Молочную продуктивность подопытного поголовья изучали на основании ежемесячных контрольных доек, содержание жира и белка в молоке - по общепринятым методам в ООО «Нальчикский молочный комбинат». Из показателей воспроизводительной способности учитывали продолжи- тельность сервис-периода, межотельного интервала и коэффициент воспроизводительной способности (КВС) по материалам зоотехнического и ветеринарного учета.

Индекс осеменения (ИО) вычисляли по формуле:

$$
\text { ИО }=K_{o} / C,
$$

где $K_{o}$ - общее число осеменений; $C$ - число стельных маток.

Коэффициент воспроизводительной способности коров (КВС) рассчитывали по формуле:

$$
\text { КВС }=365 / \text { МОП, }
$$

где 365 - количество календарных дней в году, МОП - средний межотельный период, дней.

Полученный цифровой материал исследований обработан биометрически в соответствии с руководством Н.А. Плохинского [9].

Результаты исследований. При распределении подопытного поголовья по удельно-массовому коэффициенту выявили три типа телосложения, что наглядно отражено на рисунке 1. Среди анализируемого поголовья большая часть коров (52,9\% или 72 гол.) относится к плотному типу телосложения, доминирующему в стаде, тогда как сверстниц рыхлого типа насчитывалось 14 голов или 10,3\%. Промежуточный тип телосложения был характерен для 50 голов или 36,8 \%. Различия, характерные по морфобиохимическому составу крови, между коровами разного типа телосложения показаны в таблице 1. Выявили более высокий белковый обмен в организме коров плотного типа телосложения, у которых содержание белка в сыворотке крови было на 4,0 г/л $(\mathrm{P}>0,99)$ выше по сравнению со сверстницами рыхлого типа. Последние также уступали коровам промежуточного типа в среднем на 2,3 г/л $(\mathrm{P}>0,95)$.

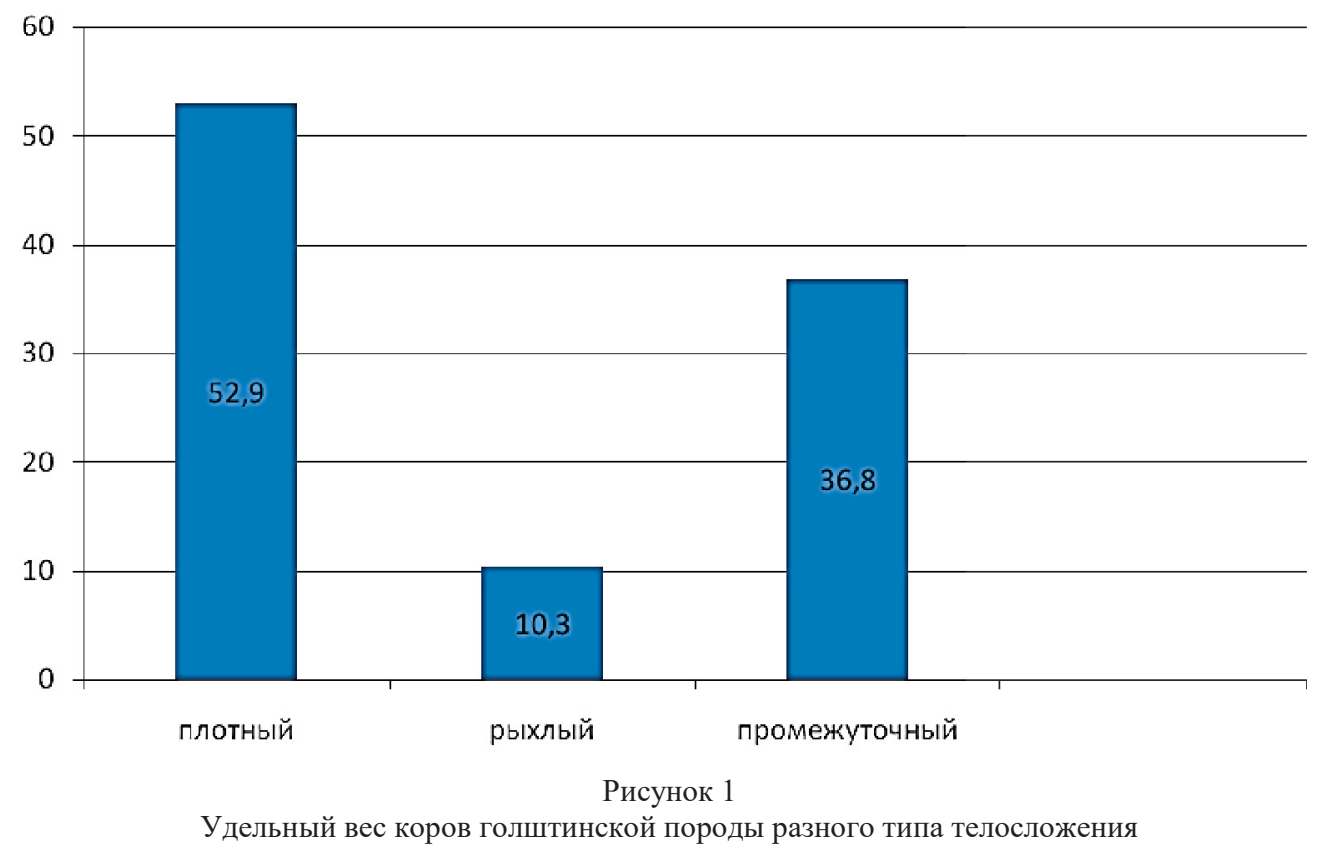


Таблица 1 Гематологические показатели коров разного типа телосложения $(\mathrm{n}=5), \mathrm{X} \pm \mathrm{m}_{\mathrm{x}}$

\begin{tabular}{|l|c|c|c|}
\hline \multirow{2}{*}{ Показатель крови } & \multicolumn{3}{|c|}{ Тип телосложения } \\
\cline { 2 - 4 } & плотный & рыхлый & промежуточный \\
\hline Общий белок, г/л & $81,3 \pm 0,76$ & $77,3 \pm 0,81$ & $114,6 \pm 0,58$ \\
\hline Гемоглобин, г/л & $117,0 \pm 1,15$ & $109,3 \pm 1,03$ & $7,3 \pm 0,07$ \\
\hline Эритроциты, $10^{12} / л$ & $7,5 \pm 0,08$ & $7,0 \pm 0,10$ & $7,6 \pm 0,08$ \\
\hline Лейкоциты, $10^{9} / л$ & $7,4 \pm 0,09$ & $8,1 \pm 0,12$ & \\
\hline
\end{tabular}

Показатели морфологического состава крови были выше и в сыворотке крови коров плотного типа телосложения, что характеризует более интенсивные обменные процессы в их организме. Так, различия по сравнению с особями рыхлого типа составили по содержанию гемоглобина 7,7 г/л (P > 0,999), эритроцитов $-0,5 \times$ $10^{12} /$ Л $(\mathrm{P}>0,99)$.

Сравнительный анализ содержания этих компонентов в крови коров промежуточного типа также выявил их более высокий уровень в сравнении со сверстницами рыхлого типа телосложения. По-видимому, интенсивные окислительно-восстановительные процессы в орга- низме объясняют более высокие молочные качества коров плотного типа телосложения относительно сверстниц других типов. Лейкоциты, как известно, выполняющие в организме защитные функции, были выше в сыворотке крови коров рыхлого типа телосложения, преимущество которых было наибольшим в сравнении с особями плотного типа (на $0,7 \times 10 \%$ л, $\mathrm{P}>0,99$ ), наименьшим - на $0,5 \times 10^{9} /$ л $(\mathrm{P}>0,99)$ относительно животных промежуточного типа. Принадлежность коров голштинской породы к разным типам телосложения обусловила различия в уровне их удоя как в отдельные месяцы, так и за всю лактацию, данные о которых представлены в таблице 2.

Таблица 2 Удои коров голштинской породы разных типов телосложения, $\mathrm{X} \pm \mathrm{m}_{\mathrm{x}}$

\begin{tabular}{|c|c|c|c|}
\hline \multirow{2}{*}{ Месяц лактации } & \multicolumn{3}{|c|}{ Тип телосложения } \\
\hline & плотный $(\mathrm{n}=72)$ & рыхлый (n = 14) & промежуточный $(\mathrm{n}=50)$ \\
\hline 1 & $793 \pm 12,3$ & $710 \pm 27,3$ & $754 \pm 15,2$ \\
\hline 2 & $856 \pm 13,0$ & $754 \pm 32,8$ & $802 \pm 16,3$ \\
\hline 3 & $892 \pm 12,4$ & $830 \pm 29,0$ & $857 \pm 17,0$ \\
\hline 4 & $869 \pm 11,6$ & $803 \pm 28,5$ & $839 \pm 15,3$ \\
\hline 5 & $835 \pm 12,5$ & $782 \pm 33,7$ & $802 \pm 14,4$ \\
\hline 6 & $783 \pm 10,3$ & $760 \pm 30,3$ & $743 \pm 15,0$ \\
\hline 7 & $747 \pm 9,2$ & $704 \pm 26,9$ & $772 \pm 13,8$ \\
\hline 8 & $570 \pm 8,0$ & $539 \pm 22,5$ & $586 \pm 10,6$ \\
\hline 9 & $469 \pm 6,8$ & $431 \pm 18,4$ & $457 \pm 8,7$ \\
\hline 10 & $392 \pm 5,1$ & $326 \pm 12,3$ & $372 \pm 6,3$ \\
\hline За 305 дней лактации & $7206 \pm 96$ & $6639 \pm 187$ & $6984 \pm 127$ \\
\hline
\end{tabular}

Во все месяцы лактации наибольший удой демонстрировали коровы плотного типа телосложения, наименьший - сверстницы рыхлого типа, что свидетельствует о необходимости увеличения в стаде коров плотного типа телосложения. Вместе с тем следует отметить, что наибольшие межгрупповые различия имели место в первую половину лактации - в период максимального производства молока. Преимущество коров плотного типа телосложения в первый месяц лактации над сверстницами рыхлого типа составило в среднем $83(\mathrm{P}>0,99)$, во второй - 102 кг $(\mathrm{P}>0,99)$, в третий - 62, в четвертый $66(\mathrm{P}>0,95)$, в пятый -53 кг. В целом за 305 дней лактации, как и ожидалось, наибольшей продуктивностью отличались коровы плотного типа телосложения, преимущество которых над сверстницами промежуточного типа составило
222 кг или 3,2 \%, рыхлого - 567 кг или 8,5 \% $(\mathrm{P}>0,99)$.

Показатели воспроизводительной способности коров голштинской породы разных типов телосложения представлены в таблице 3. По итогам осеменения коров наибольшей оплодотворяемостью от первого осеменения отличались коровы плотного типа телосложения, у которых она была больше, чем у сверстниц плотного типа, на 5,4 \%, рыхлого - на 12,3\%. Полученные результаты по оплодотворяемости коров плотного типа телосложения после первого осеменения являются положительным фактом, свидетельствующем о более раннем наступлении стельности и возможности получения телят в течение календарного года. Эта закономерность подтверждается и величиной индекса осеменения, который составил 1,6 ед. против 2,0 ед. у 
особей рыхлого типа (P > 0,999). Значения, полученные по затратам доз семени, необходимых для плодотворного осеменения, коров промежуточного типа приближались к уровню, зарегистрированному у представительниц плотного типа телосложения при различиях на уровне 0,1 доз семени $(\mathrm{P}>0,95)$. Более продолжительный сервис-период установлен у особей рыхлого типа - 104 суток, что больше на 13 суток, чем у коров промежуточного типа $(\mathrm{P}>0,95)$, и на 21 суток - плотного типа $(\mathrm{P}>0,99)$. В соответствии с этим различия по межотельному интервалу составили 12 и 19 суток соответственно.

Анализируя коэффициент воспроизводительной способности, характеризующий выход телят в течение года, можно отметить, что этому критерию соответствовали коровы плотного типа телосложения, у которых он составил 0,99 ед., что выше значений, полученных от сверстниц рыхлого типа, на 0,04 ед. (Р>0,95), а животные промежуточного типа занимали срединное положение между крайними значениями признака.

Таблица 3 Репродуктивные качества коров разных типов телосложения, $\mathrm{X} \pm \mathrm{m}_{\mathrm{x}}$

\begin{tabular}{|c|c|c|c|c|}
\hline \multirow{2}{*}{\multicolumn{2}{|c|}{ Показатель }} & \multicolumn{3}{|c|}{ Тип телосложения } \\
\hline & & \multirow{2}{*}{$\begin{array}{c}\text { плотный } \\
50\end{array}$} & \multirow{2}{*}{$\begin{array}{c}\text { рыхлый } \\
8\end{array}$} & \multirow{2}{*}{$\begin{array}{c}\text { промежуточный } \\
32\end{array}$} \\
\hline Оплодотворяемость & гол. & & & \\
\hline после первого осеменения: & $\%$ & 69,4 & 57,1 & 64,0 \\
\hline \multicolumn{2}{|l|}{ Индекс осеменения, доз семени } & $1,6 \pm 0,03$ & $2,0 \pm 0,05$ & $1,7 \pm 0,04$ \\
\hline \multicolumn{2}{|l|}{ Сервис-период, сут. } & $83 \pm 3,0$ & $104 \pm 5,4$ & $91 \pm 2,8$ \\
\hline \multicolumn{2}{|l|}{ Межотельный период, сут. } & $367 \pm 9,3$ & $386 \pm 20,2$ & $374 \pm 12,5$ \\
\hline \multicolumn{2}{|l|}{ KBC } & $0,99 \pm 0,01$ & $0,95 \pm 0,02$ & $0,97 \pm 0,02$ \\
\hline
\end{tabular}

Вывод. В стаде голштинского скота чернопестрой масти доминирующим типом телосложения является плотный (53\%), менее представительным - рыхлый тип (10\%), что имеет положительное значение для увеличения произ- водства молока, так как в отличие от особей промежуточного и особенно рыхлого типов, плотные характеризуются более высоким уровнем удоя, интенсивным обменом веществ в организме и воспроизводительной способностью.

\section{Библиографический список}

1. Стрекозов, Н.И. Совершенствовать методы оценки молочного скота [Текст] / Н.И. Стрекозов, Г.Н. Крылова // Зоотехния. 1997. № 4. C. 2.

2. Амерханов, Х. Особенности селекции крупного рогатого скота молочного направления продуктивности в Российской Федерации [Текст] / Х. Амерханов, И. Янчуков, А. Ермилов, С. Харитонов // Молочное и мясное скотоводство. 2012. № 1. С. 15-18.

3. Любимов, А.И. Экстерьерные особенности и молочная продуктивность коров чернопестрой породы разных генераций [Текст] / А.И. Любимов, Е.Н. Мартынова, Ю.В. Исупова, Е.В. Ачкасова, Е.А. Ястребова // Ученые записки Казанской государственной академии ветеринарной медицины им. Н.Э. Баумана. 2018. T. 233. № 1. С. 98-102.

4. Колесник, Н.Н. Методика определения типов конституции животных [Текст] / Н.Н. Колесник // Животноводство. 1960. №3. С. 48-51.

5. Пустотина, Г.Ф. Экстерьерно-конституциональные типы симментальского скота в зоне Южного Урала [Текст] / Г.Ф. Пустотина // Известия Оренбургского государственного аг- рарного университета. 2005. № 1 (5). С. 112113.

6. Шевелева, О.М. Экстерьер скота разного происхождения [Текст] / О.М. Шевелева, М.А. Свяженина, М.А. Часовщикова // Сибирский вестник сельскохозяйственной науки. 2012. № 5 (228). С. 42-46.

7. Шаталов, С.В. Экстерьер высокоинтенсивного молочного скота [Текст] / С.В. Шаталов, В.С. Шаталов, В.К. Томилин, Я.В. Кочуева // Политематический сетевой электронный научный журнал Кубанского государственного аграрного университета. 2013. № 91. С. 1238-1248.

8. Улимбашев, М.Б. Оценка молочного скота по индексу специализации и производственной типичности [Текст] / М.Б. Улимбашев, Ж.Т. Алагирова, А.С. Гуазова // Российская сельскохозяйственная наука. 2016. № 1. С. 45-47.

9. Плохинский, Н.А. Руководство по биометрии для зоотехников [Текст] / Н.А. Плохинский. М, 1969. 256 с.

10. Тагиров, Х.Х. Продуктивные качества чистопородных и помесных бычков [Текст] / Х.Х. Тагиров, Р. Давлетов, Р. Шакиров // Молочное и мясное скотоводство. 2007. № 3. С. 31-32. 
11. Юсупов, Р. Влияние голштинизации на продуктивность коров и экологическую безопасность продукции [Текст] / Р. Юсупов, Х. Тагиров, Э. Андриянова // Молочное и мясное скотоводство. 2008. № 6. С. 19-20.
12. Тагиров, Х.Х. Факторы, влияющие на мясную продуктивность молодняка крупного рогатого скота [Текст] / Х.Х. Тагиров, Н.В. Гизатова // Вестник мясного скотоводства. 2009. Т. 2. № 62. C. 164-171.

\section{Сведения об авторе}

Улимбашев Мурат Борисович, доктор сельскохозяйственных наук, доцент, ведущий научный сотрудник отдела кормления и кормопроизводства, ФГБНУ «Северо-Кавказский федеральный научный аграрный центр», 356241, Ставропольский край, г. Михайловск, ул. Никонова, 49, e-mail: murat-ul@ yandex.ru.

Предложен метод выявления типа конституции крупного рогатого скота по удельно-массовому коэффициенту (УМК). Цель работы заключалась в распределении коров голштинской породы черно-пестрой масти по типу конституции на основе предлагаемого способа определения удельно-массового коэффициента и выявления обильномолочного типа коров. Исследования проводили в КФХ «Балагов», расположенном в Баксанском районе Кабардино-Балкарской Республики. Экстерьерно-конституциональные типы коров голштинской породы черно-пестрой масти устанавливали по удельно-массовому коэффициенту (УМК) по предложенной нами формуле:

$$
y M K=\frac{2500 \times M}{\Gamma_{2} \times K_{\partial} \times\left(W_{2}+W_{m}\right)},
$$

где $M$ - живая масса коровы, кг; $\Gamma_{2}-$ глубина груди, см; $W_{2}$ - ширина груди, см; $W_{m}$ - ширина в тазобедренных сочленениях, см; $K_{\partial}-$ косая длина туловища (мерной палкой), см. Распределение коров на типы телосложения проводили по величине УМК: рыхлый (1,36 и менее), промежуточный $(1,37-1,54)$ и плотный $(1,55$ и более). Распределение анализируемого поголовья выявило, что большая часть коров (52,9 \% или 72 гол.) относится к плотному типу телосложения, 14 голов или 10,3\% - к рыхлому типу и 50 голов или $36,8 \%$ - к промежуточному типу. За 305 дней лактации наибольшим удоем характеризовались коровы плотного типа телосложения, преимущество которых над сверстницами промежуточного типа составило 222 кг или $3,2 \%$, рыхлого - 567 кг или 8,5 \% (P > 0,99). Более продолжительный сервис-период установлен у особей рыхлого типа - 104 суток, что больше на 13 суток, чем у коров промежуточного типа $(\mathrm{P}>0,95)$, и на 21 суток - плотного типа $(\mathrm{P}>0,99)$. Коэффициент воспроизводительной способности у коров плотного типа телосложения составил 0,99 ед., что выше значений, полученных от сверстниц рыхлого типа, на $0,04$ ед. (P $>0,95)$, а животные промежуточного типа занимали срединное положение между крайними значениями признака.

M. Ulimbashev

\section{HOLSTEIN CATTLE CONSTITUTION TYPES DEPENDING ON THE SPECIFIC WEIGHT RATE}

Key words: Holstein breed; cows; specific weight rate; type of constitution; productivity.

\section{Authors' personal details}

Ulimbashev Murat, Doctor of agricultural sciences, associate professor, leading researcher of the department of feeding and feed production, North-Caucasian Federal Scientific Agrarian Center, 356241, Stavropol krai, Mikhaylovsk, Nikonov Street, 49, e-mail: murat-ul@yandex.ru.

The paper presents a method to identify the type of cattle constitution by the specific weight rate. The aim of the work was to divide black-and-white Holstein cows according to the constitution type based on the proposed method of determining the specific weight rate and revealing cows of the abundant milk type. Studies were conducted in the Balagov farm, located in the Baksan district of the Kabardino-Balkarian Republic. The exterior-constitutional types of black-and-white Holstein cows were determined 
by the specific weight rate according to the formula proposed by us: where $M$ is the live weight of the cow, kg; $G_{g}$ - the depth of the chest, cm; $W_{g}$ - width of the breast, $\mathrm{cm} ; P_{c}-$ width at the hip joints, $\mathrm{cm} ; C_{d}$ - slanting body length (measuring stick), see. Distribution of cows for body types was carried out according to the specific weight rate: loose $(1,36$ or less), intermediate $(1,37-1,54)$ and dense $(1,55$ and more). The distribution of the analyzed livestock revealed that most of the cows $(52,9 \%$ or 72 heads) belong to a dense body type, 14 heads or $10,3 \%$ to a loose type and 50 heads or $36,8 \%$ to an intermediate type. For 305 days of lactation, cows of dense

(c) Улимбашев М.Б. body type were characterized by the highest milk yield, the advantage of which over intermediate peers was $222 \mathrm{~kg}$ or $3,2 \%$, loose $-567 \mathrm{~kg}$ or $8,5 \%$ $(\mathrm{P}>0,99)$. A longer service period of 104 days is found for loose-type cows being 13 days longer than of intermediate-type cows $(\mathrm{P}>0,95)$ and 21 days more than of a dense type cattle $(\mathrm{P}>0,99)$. The reproduction ability coefficient of a dense body type was 0,99 units, that is higher than the values obtained from cows of the loose type by 0,04 units. $(\mathrm{P}>0,95)$. Animals of the intermediate type occupied the middle position between the extreme values of the trait.

УДК 621.313.33:631.3

DOI: $10.31563 / 1684-7628-2019-51-3-74-82$

Р.С. Аипов, Д.С. Леонтьев, В.Ю. Кабашов

\section{ЭКСПЕРИМЕНТАЛЬНОЕ ИССЛЕДОВАНИЕ ЛИНЕЙНОГО ЭЛЕКТРОПРИВОДА ДВУХНОЖЕВОГО РЕЖУЩЕГО АППАРАТА ЖАТКИ ЗЕРНОУБОРОЧНОГО КОМБАЙНА}

\section{Ключевые слова: линейный электропривод; возвратно-поступательное движение; режущий ап- парат; ножевая полоса; плоский линейный асинхронный двигатель; индуктор; вторичный элемент.}

Введение. На сегодняшний день в жатках зерноуборочных комбайнов широко применяются режущие аппараты с возвратно-поступательным движением ножевых полос [10]. Данные аппараты бывают подпорного (сегментнопальцевые) и бесподпорного (двухножевые) типов [4]. Сегментно-пальцевые режущие аппараты нормального резания с одинарным пробегом ножа применяются в широком большинстве [11]. Именно они по умолчанию устанавливаются заводами-изготовителями в жатки комбайнов, предназначенных для уборки зерновых культур [8]. Однако уборку зернобобовых и полегших зерновых культур ссегментно-пальцевыми режущими аппаратами осуществить не всегда представляется возможным, так как происходит постоянное забивание режущей части убираемой культурой, при этом сама уборка происходи на малой поступательной скорости комбайна с большой частотой вращения приводного двигателя. В таких условиях перспективным направлением является применение двухножевых режущих аппаратов, ножи которых совершают встречное возвратно-поступательное движение [7]. При этом режущий аппарат практически не забивается культурой при уборке, и ее можно проводить на повышенной поступательной скорости движения комбайна.
Одним из существенных недостатков, тормозящим применение двухножевых режущих аппаратов в жатках комбайнов, является сложная конструкция привода ножей с большим количеством кинематических звеньев и сложной системой преобразования вращательного движения приводного вала в возвратно-поступательное движение ножей режущего аппарата [12].

Авторами предложена конструкция электропривода двухножевого режущего аппарата на основе линейных асинхронных двигателей, устраняющая выше приведенные недостатки [9].

Цель и задачи исследования - создание и экспериментальное исследование работы режущего аппарата жатки комбайна с линейным электроприводом в лабораторных и полевых условиях. Поставлены и решены следующие задачи: разработан экспериментальный образец линейного электропривода режущего аппарата жатки комбайна и исследована его работа в полевых условиях.

Условия, материалы и методы исследования. Компоновка жатки с электрическим приводом основных элементов представлена на рисунке 1 . При создании образца учитывались рекомендации, ранее изложенные в [5], [9]. 


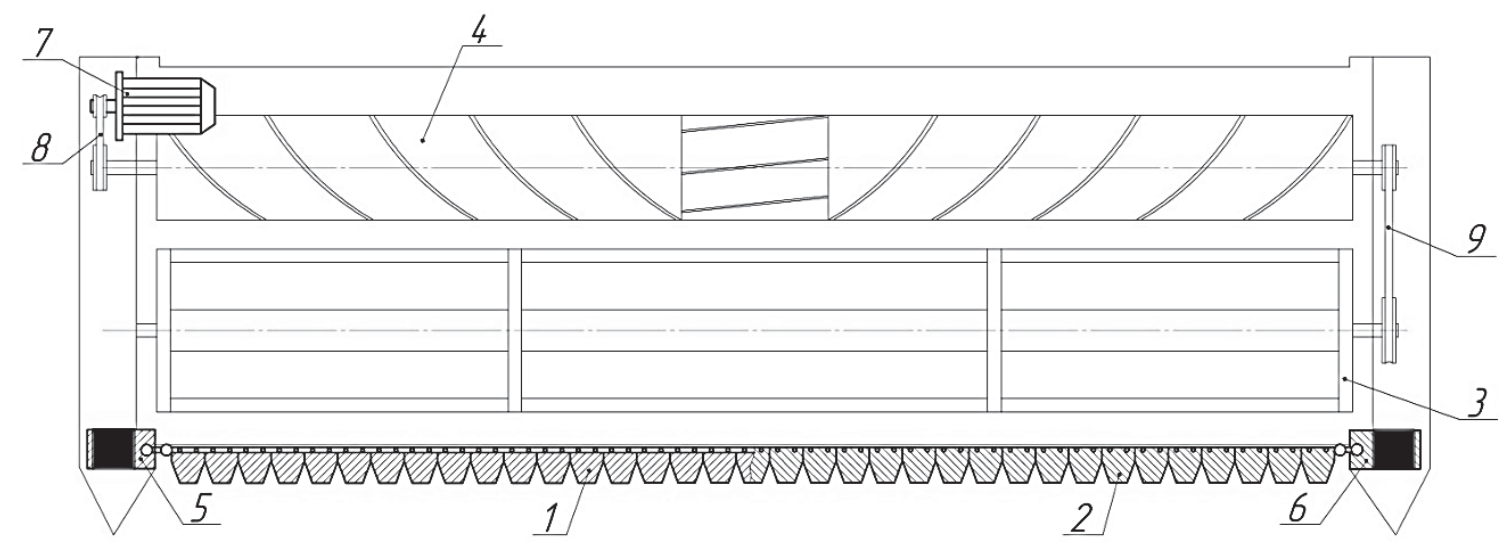

Рисунок 1

Компоновка элементов жатки комбайна с линейным электроприводом режущего аппарата (вид сверху): 1, 2 - верхняя и нижняя ножевые полосы режущего аппарата; 3 - винтовой шнек; 4 - планчатое мотовило; 5, 6- линейные асинхронные двигатели привода ножевых полос; 7 - асинхронный двигатель вращения винтового шнека и планчатого мотовила; 8,9 - клиноременные передачи

В корпусе жатки располагаются режущий аппарат [13], состоящий из верхней 1 и нижней 2 ножевых полос с трапецеидальными сегментами, планчатое мотовило 3, необходимое для подгибания убираемой массы растений к режущему аппарату и винтовой шнек 4, служащий для направления срезанной массы к молотильной части комбайна. Ножевые полосы 1 и 2 режущего аппарата получают колебательное встречное возвратно-поступательное движение непосредственно от линейных асинхронных двигателей 5 и 6 [2]. Планчатое мотовило 3 и винтовой шнек 4 приводятся в движение с помощью асинхронного двигателя вращения 7 через клиноременные передачи 8 и 9. Конструкция электропривода режущего аппарата предусматривает установку линейных электродвигателей [6], [15] в стандартные посадочные места, где ранее располагались преобразователи враща- тельного вида движения в поступательное, например, планетарного типа [10].

Привод каждой ножевой полосы осуществляется от отдельного двухстороннего плоского линейного асинхронного двигателя (ДПЛАД) [1], конструкция которого приведена на рисунке $2, a$. ДПЛАД содержит верхний 1 и нижний 2 индукторы, закрепленные непосредственно в корпусе 3 , жестко присоединенном к корпусу жатки комбайна и обхватывающие вторичный элемент 4. Между индукторами и вторичным элементом ДПЛАД устанавливается наименьший воздушный зазор перемещением индукторов вверх или вниз и закреплением их регулировочными болтами 5. Вторичный элемент 4 ДПЛАД перемещается во фторопластовых подшипниках скольжения 6 и 7, шарнирно соединяется с верхней либо нижней ножевыми полосами режущего аппарата.

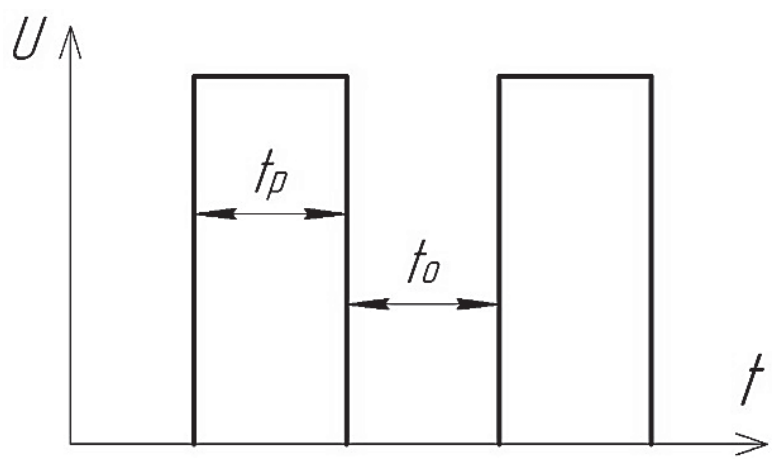

б)

Рисунок 2

Устройство ДПЛАД и иллюстрация его режима питания: a) устройство ДПЛАД; б) питание ДПЛАД в режиме вынужденных колебаний; 1 - верхний индуктор ДПЛАД; 2 - нижний индуктор ДПЛАД; 3 - корпус ДПЛАД; 4 - вторичный элемент ДПЛАД; 5 - крепежно-регулировочные болты индукторов; 6, 7 - фторопластовые подшипники скольжения; $t_{p}$ - время включенного состояния ДПЛАД; $t_{o}-$ время выключенного состояния ДПЛАД 
При создании линейного электропривода экспериментальной установки использовали выпускаемую продукцию ООО «Ставропольский электромеханический завод». В качестве индук-

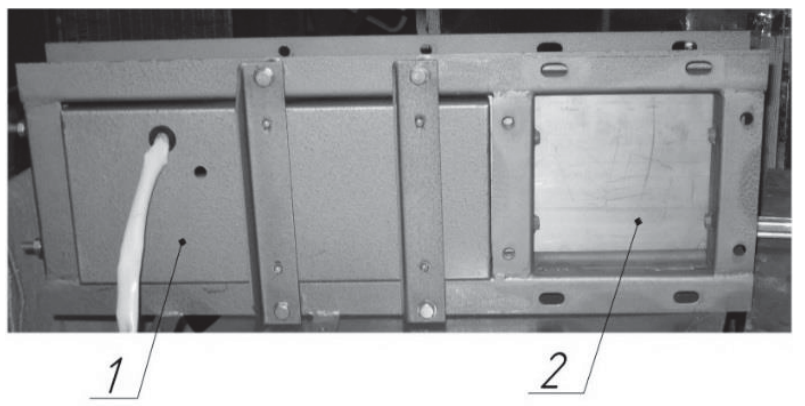

a) торов применялись изделия марки У2-Б3Б20. 00000-01, вторичного элемента - изделия марки У2-Б3Б00.025. Внешний вид элементов, применяемых в ДПЛАД приведены на рисунке 3.
Рисунок 3
Внешний вид элементов ДПЛАД:
a) внешний вид собранного ДПЛАД с установленными индукторами 1 и вторичным элементом 2;
б) внешний вид индукторов ДПЛАД

Параметры индукторов:

- габаритные размеры индуктора (длина $\times$ ширина $\times$ высота): $230 \times 200 \times 60$ мм;

- число полюсов: $2 p=4$;

- полюсное деление: $\tau=0,0425$ м;

- число зубцов: $z=13$;

- напряжение и частота питающей сети: $U_{H}=380 \mathrm{~B}, f=50$ Гц;

- пусковое тяговое усилие $F_{n}=500 \mathrm{H}$;

- синхронная скорость $V_{0}=4,25 \mathrm{~m} / \mathrm{c}$.

Параметры вторичного элемента ДПЛАД:

- габаритные размеры (длина $\times$ ширина $\times$ высота): $230 \times 350 \times 8$ мм;

- материал: алюминиевый лист.

Параметры схемы замещения ДПЛАД [14], согласно данным завода изготовителя, состав- ляют: $R_{1}=6,92$ Ом; $R_{2}{ }^{\prime}=4,09$ Ом; $X_{1}=4,86$ Ом; $X_{2}{ }^{\prime}=0,254$ Ом; $X_{m}=2,67$ Ом.

Использование в ДПЛАД индукторов с числом пар полюсов, равным двум, приводит к усилению краевых эффектов [3], которые проявляются наложением на основную электромагнитную силу, развиваемую ДПЛАД и приводящую в движение режущий аппарат, дополнительной переменной высокочастотной силы с частотой, двукратной частоте переменного напряжения источника. Это повышает эффективность процесса резания ножевыми полосами: уменьшается как усилие резания, так и износ режущих кромок сегментов ножевых полос.

Кинематическая схема линейного электропривода режущего аппарата приведена на рисунке 4.

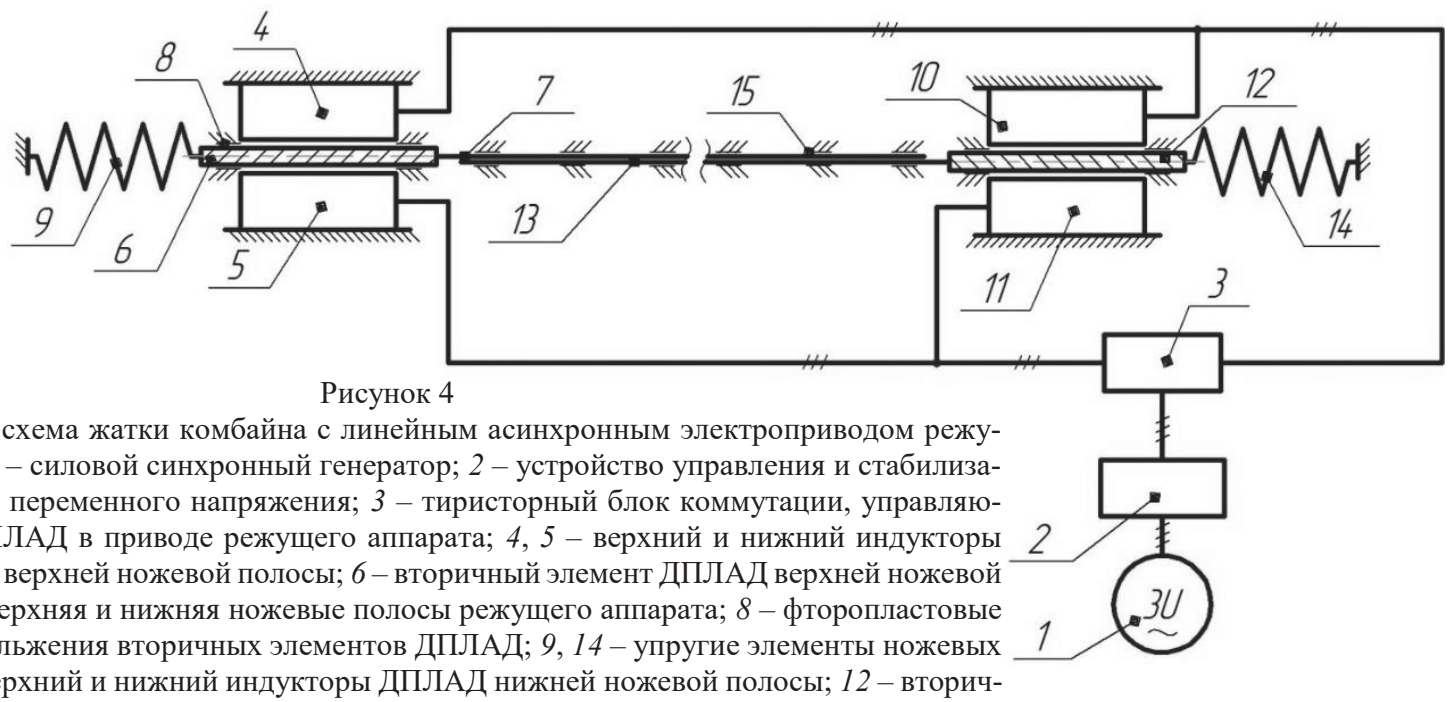

Кинематическая схема жатки комбайна с линейным асинхронным электроприводом режущего аппарата: 1 - силовой синхронный генератор; 2 - устройство управления и стабилизации трехфазного переменного напряжения; 3 - тиристорный блок коммутации, управляющий работой ДПЛАД в приводе режущего аппарата; 4, 5 - верхний и нижний индукторы ДПЛАД привода верхней ножевой полосы; 6 - вторичный элемент ДПЛАД верхней ножевой полосы; 7, 13 - верхняя и нижняя ножевые полосы режущего аппарата; 8 - фторопластовые подшипники скольжения вторичных элементов ДПЛАД; 9, 14 - упругие элементы ножевых полос; 10, 11 - верхний и нижний индукторы ДПЛАД нижней ножевой полосы; 12 - вторичный элемент ДПЛАД нижней ножевой полосы; 15 - прижимные пластины ножевых полос

Линейный электропривод режущего аппарата работает следующим образом. Силовой ге- нератор синхронного типа 1 , приводимый в движение от двигателя внутреннего сгорания ком- 
байна через электромагнитную муфту, вырабатывает трехфазное линейное переменное напряжение величиной 380 В и частотой 50 Гц. Далее это напряжение стабилизируется по величине в устройстве 2 и подается к тиристорному блоку коммутации 3 , управляющего работой ДПЛАД режущего аппарата жатки. Тиристорный блок коммутации подает напряжение на ДПЛАД в импульсном режиме, тем самым обеспечивая режим вынужденных колебаний (рисунок 2,б). В режиме вынужденных колебаний ДПЛАД режущего аппарата подключается и отключается к питающей сети, формируемой силовым генератором, тиристорным блоком коммутации 3 с определенными интервалами, позволяя настраивать необходимую технологическую амплитуду и частоту колебаний ножевых полос.

Привод верхней ножевой полосы работает следующим образом. При подключении ДПЛАД к трехфазной системе питания, электрический ток в индукторах начинает создавать бегущее магнитное поле. Попутно-направленные магнитные поля в верхнем 4 и нижнем 5 индукторах ДПЛАД (рисунок 4), взаимодействуя с токами, индуцируемыми в замкнутом контуре вторичного элемента 6, вызывают появление электромагнитных сил и перемещение вторичного элемента, шарнирно соединенного с ножевой полосой 7 в направлении электромагнитных сил влево от центра жатки. По мере движения вторичного элемента 6 во фторопластовых подшипниках скольжения 8 происходит деформация упругого элемента 9. До момента его полного сжатия происходит отключение ДПЛАД от сети с помощью тиристорного блока коммутации. Под действием накопленной потенциальной энергии в сжатом упругом элементе 9, происходит движение ножевой полосы 7 в обратном направлении - к центру жатки. По мере движения ножевой полосы 7 упругий элемент 9 возвращаются в исходное положение, затем происходит повторное подключение ДПЛАД 5 (рисунок 1) к силовому синхронному генератору. Процесс повторяется.

Привод нижней ножевой полосы работает аналогично приводу верхней. Подключение ДПЛАД 6 (рисунок 1) к трехфазной системе питания, формируемой силовым генератором, происходит одновременно с подключением ДПЛАД 5 , но в противофазном режиме, за счет чего ножевые полосы 1 и 2 движутся встречно по отношению друг к другу.

Для проверки возможности реализации кинематической схемы, приведенной на рисунке 4, на кафедре электрических машин и электрооборудования на основе разработанной математи- ческой модели [5], теоретическое исследование которой производилось в программе объектновизуального моделирования Matlab (приложение Simulink), создан лабораторный экспериментальный образец привода режущего аппарата, внешний вид и некоторые элементы которого приведен на рисунках $5, a, 5,6, \ldots 5, e$, и тиристорный блок коммутации ДПЛАД в приводе, приведенный на рисунке 5,б.

Экспериментальная лабораторная установка позволила исследовать работу ДПЛАД в приводе двухножевого режущего аппарата на холостом ходу, согласовать совместную работу двух ДПЛАД в приводе режущего аппарата, получить экспериментальные амплитудно-частотные характеристики движения ножевых полос, времятоковые характеристики ДПЛАД и т. д. Также отдельно проведено экспериментальное исследование работы тиристорного блока коммутации (рисунок 5,б). Тиристорная коммутация применяется по причине необходимости обеспечения частоты колебаний ножевых полос в диапазоне $3 . .5$ Гц, что не позволяло применить для управления ДПЛАД релейно-контакторной аппаратуры.

Проведенные экспериментальные исследования в лабораторных условиях показали, что для эффективной работы режущего аппарата предпочтительной является работа ДПЛАД в режиме вынужденных колебаний. При этом исключаются датчики положения и появляется возможность настраивать параметры колебаний ножевых полос согласно технологическому процессу резания.

Для проведения полевых испытаний электропривод режущего аппарата на основе ДПЛАД был установлен в жатку комбайна типа ЖВН-6, которая агрегатировалась с шасси на базе самоходной косилки типа КПС. Этапы проведения испытаний приведены на рисунке 6 .

Двухножевой режущий аппарат стандартной длиной 4,2 м с линейным электроприводом установлен в центре жатки, ЖВН-6 длиной 6 м, как приведено на рисунке 6,a. Установка ДПЛАД верхней и нижней ножевых полос приведена на рисунках 6,8 и 6,2. Трехфазное напряжение на ДПЛАД режущего аппарата подавалось с тиристорного блока коммутации (рисунок 6,б), установленным в мобильной дизель-генераторной установке, приведенной на рисунке $6, \partial$.

Полевые испытания проводились во второй половине сентября 2018 года в СПК «Ярославский» Дуванского района Республики Башкортостан. В ходе проведения экспериментальных исследований осуществлялась уборка участка 
поля с полегшим ячменем сорта «Красноуфимский». Уборка злаковых происходила на пяти заранее подготовленных участках поля размером $300 \times 4$ м каждый. На каждом участке уборка велась по заранее подготовленной методике с определенной скоростью движений и частотой колебаний ножевых полос. Скорость движения комбайна на участке № 1 была равна 5 км/ч, на
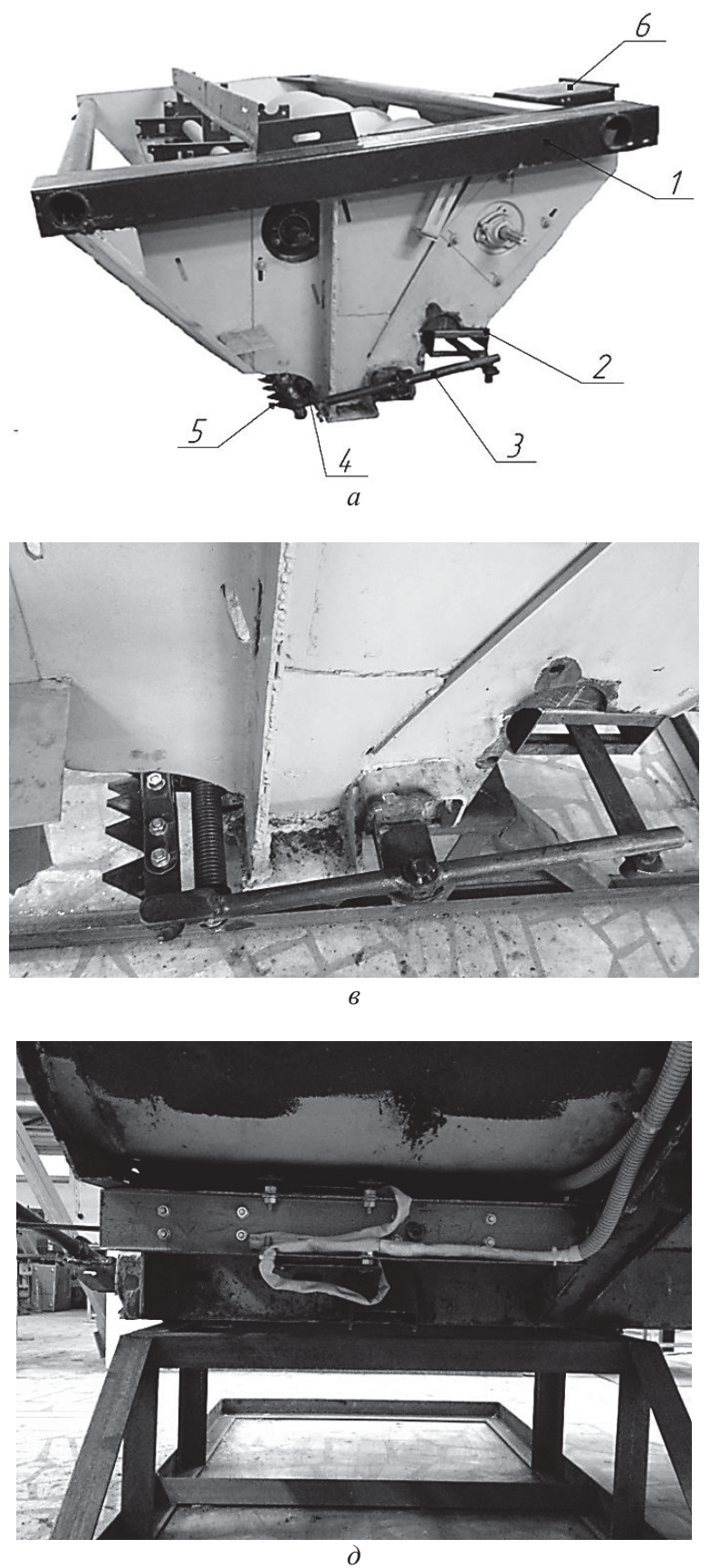

участке № 2 - 6 км/ч, и т. д. На участке № 5 скорость уборки равнялась 9 км/ч. Каждый участок также был разделен на зоны размером $100 \times 4$ м. В зоне № 1 частота колебаний ножевых полос режущего аппарата равнялась 2 Гц, в зоне № 2 3 Гц, в зоне № 3 - 4 Гц. Момент окончания уборки культуры в зоне № 3 участка № 5 приведен на рисунке $6, e$.
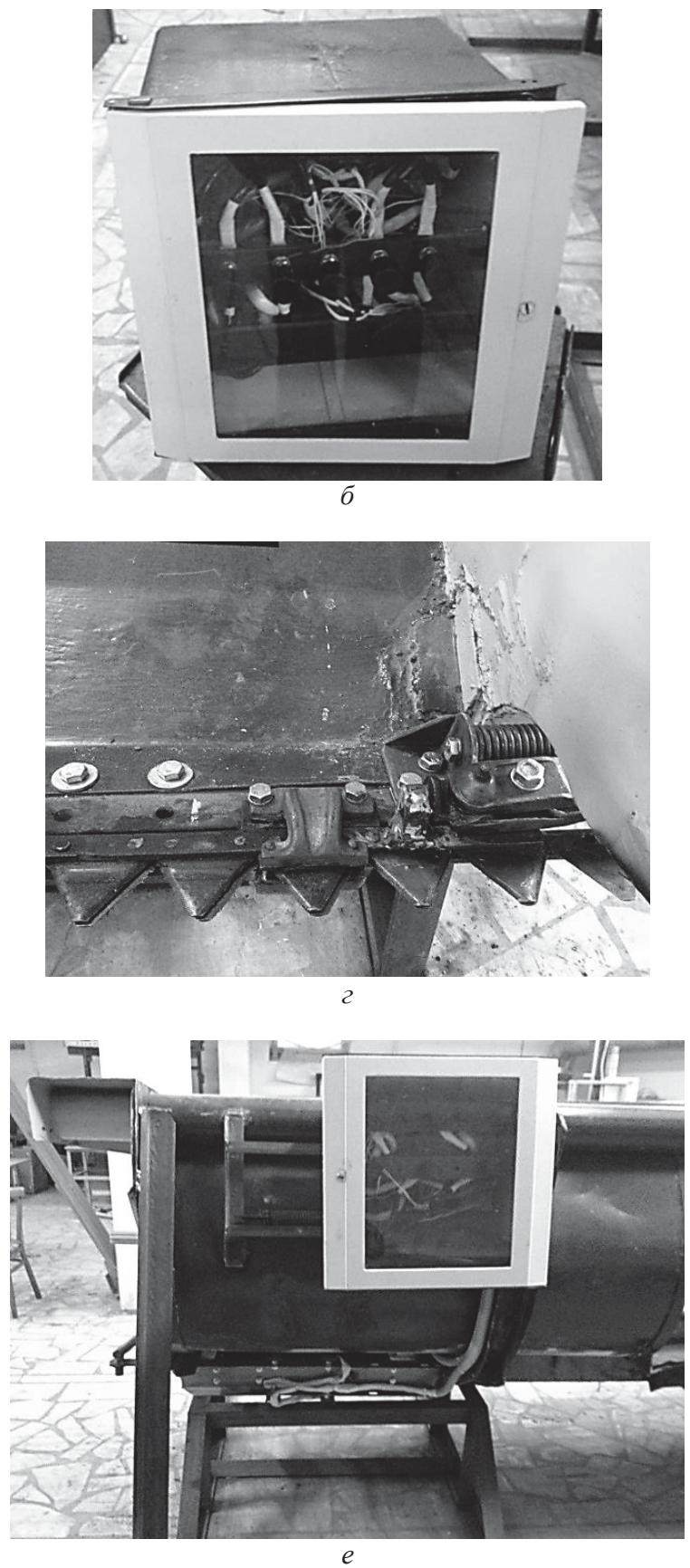

Рисунок 5

Лабораторный экспериментальный образец жатки комбайна с электроприводом двухножевого режущего аппарата на основе ДПЛАД: $a$ - конструкция экспериментального лабораторного образца жатки с электроприводом; $\sigma$ - тиристорный блок коммутации ДПЛАД; $в, 2$ - соединение ДПЛАД с ножевой полосой и положение установленного упругого элемента; $\partial$ - установленный ДПЛАД верхней ножевой полосы в корпусе жатки; $e$ - установленный тиристорный блок коммутации и подключенный к нему ДПЛАД; 1 - корпус жатки; 2 - ДПЛАД привода нижней ножевой полосы; 3 - рычажно-шарнирная система; 4 - упругий элемент нижней ножевой полосы; 5 - верхняя ножевая полоса режущего аппарата; 6 - тиристорный блок коммутации ДПЛАД 


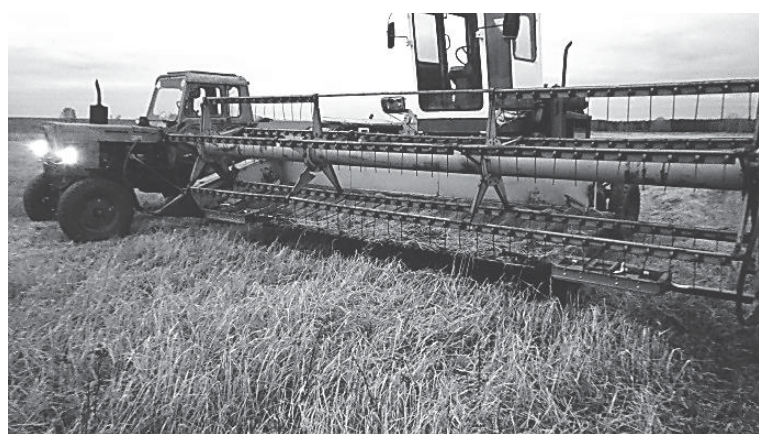

$a$
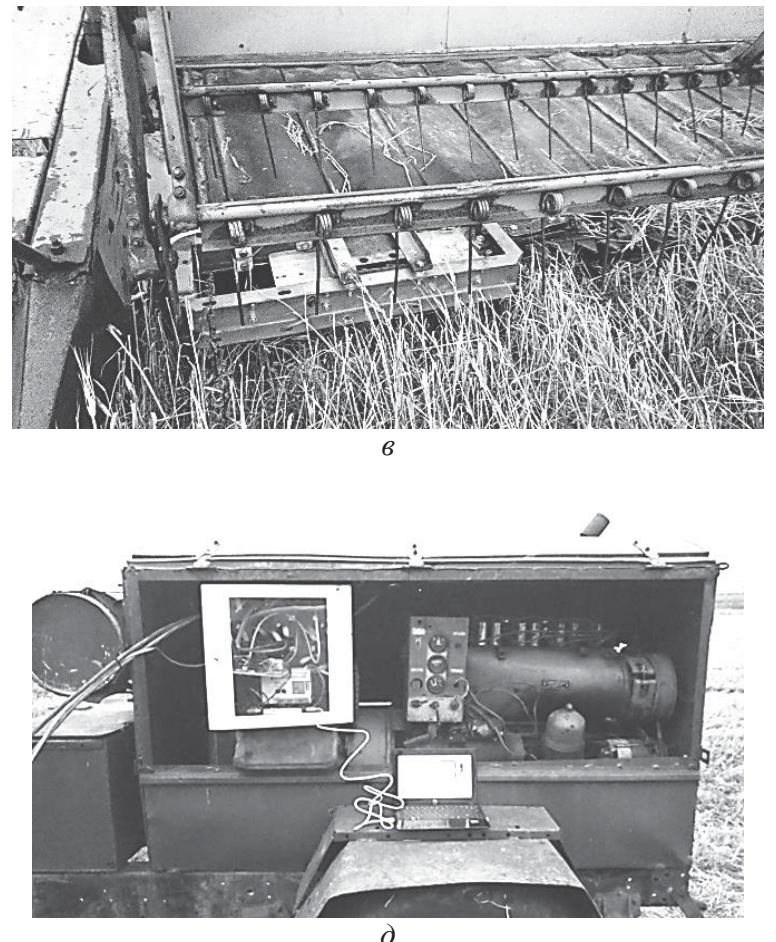
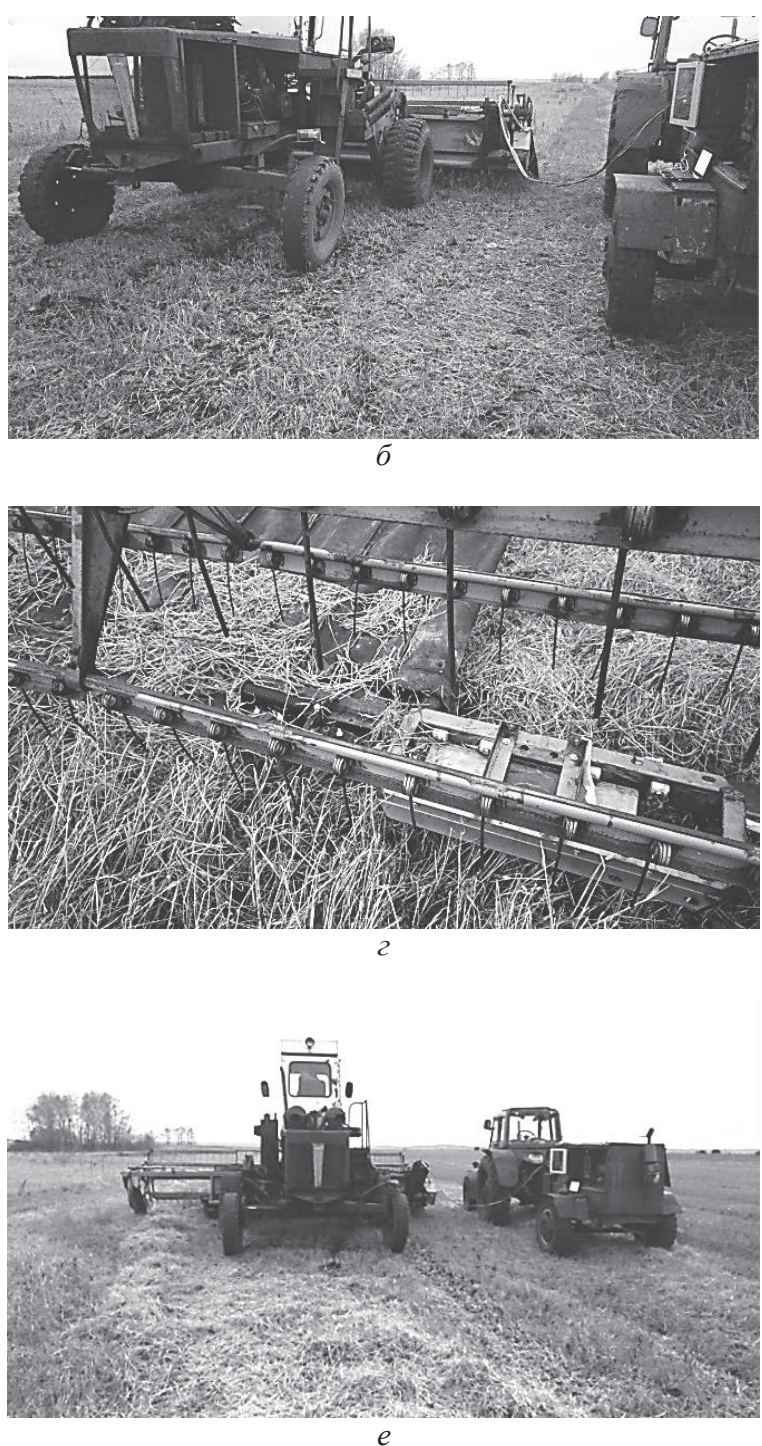

Рисунок 6

Полевые испытания электропривода двухножевого режущего аппарата жатки комбайна на основе ПЛАД: $a$ - жатка комбайна с установленным экспериментальным линейным приводом режущего аппарата; $\sigma$ - подключенный линейный электропривод режущего аппарата к дизель-генераторной установке; 6,2 - установленные ДПЛАД привода верхней и нижней ножевых полос; $\partial$ - мобильная дизель-генераторная установка мощностью 10 кВА; $e-$ момент окончания уборки зоны № 3 участка № 5 при проведения экспериментальных исследований работы режущего аппарата на поле

Для снятия экспериментальных характеристик электропривода режущего аппарата и их дальнейшего анализа в корпусе жатки комбайна были закреплены датчики линейных перемещений марки GEFRAN LTS09N09KB5C, приведенные на рисунке 7,a. Для определения величины токов, потребляемых ДПЛАД, в тиристорном блоке коммутации были установлены датчики тока марки CSLA1CF, приведенные на рисунке 7,6 , позволяющие бесконтактным способом измерять постоянную, переменную и импульсную величину токов.

Bсе измерительные приборы прошли поверку в установленном порядке с выдачей свидетельств.

Для подачи напряжения на датчики использовался многоканальный блок питания БП-98-7-Х.
Измерение перемещений ножевых полос режущего аппарата жатки производилось путем снятия выходного напряжения с датчиков линейного перемещения, которые своей подвижной частью жестко связывались с ножевой полосой, а неподвижной к - основанию жатки. Сигнал с датчиков посредством аналого-цифрового преобразователя (АЦП) (рисунок 7,6) передавался на ноутбук и выводился в рабочем окне специализированной программы с последующим сохранением характеристик.

Результаты исследования. В ходе проведения экспериментов в полевых условиях были получены токовые и амплитудно-частотные характеристики работы линейного привода режущего аппарата. Для сравнения полученных на экспериментальной установке и теоретических 
зависимостей, полученных с помощью математического моделирования [5], совместили их на одном графике. На рисунке 8 приведены характеристики, соответствующие уборке культуры в зоне № 3 участка № 5 поля.

Анализ временных зависимостей величины тока индукторов ДПЛАД (рисунок 8,a) при сравнении по максимальной амплитуде и длительности импульса, потребляемого индукторами ДПЛАД, свидетельствует о том, что при

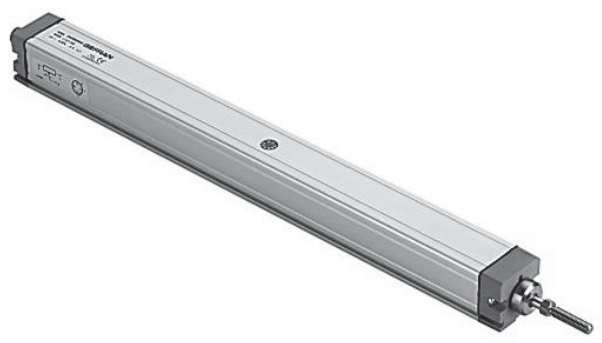

a)
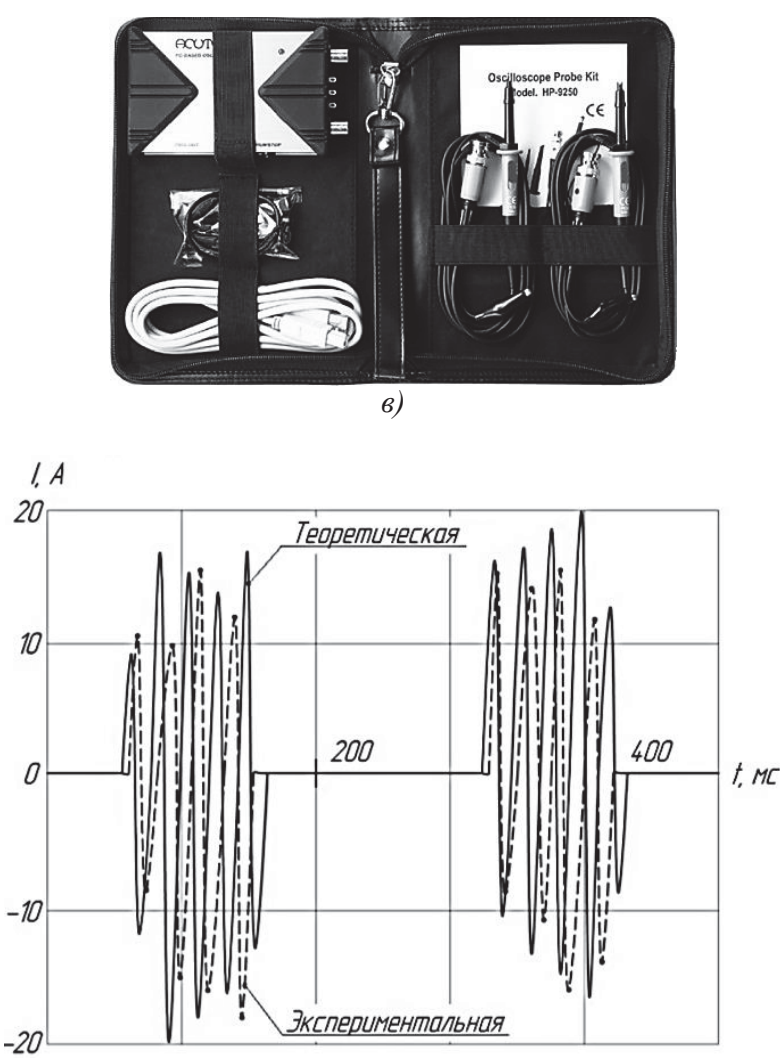

a) работе линейного электропривода режущего аппарата в установившемся режиме различие составляет не более 1,9 А, что составляет не более $8,8 \%$.

Совмещение экспериментальной временной зависимости амплитуды колебаний ножевых полос режущего аппарата с теоретической, позволяет сделать вывод о том, что отличие амплитуды колебаний не выходит за предел 8,4 \% (рисунок 8,6 ).

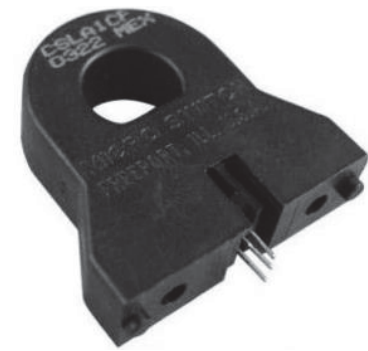

б)

Рисунок 7

Оборудование, применяемое при проведении полевых испытаний электропривода режущего аппарата: a) датчик линейных перемещений GEFRAN LTS09N 09KB5C; б) датчик тока марки CSLA1CF; в) аналого-цифровой преобразователь марки Acute-1102

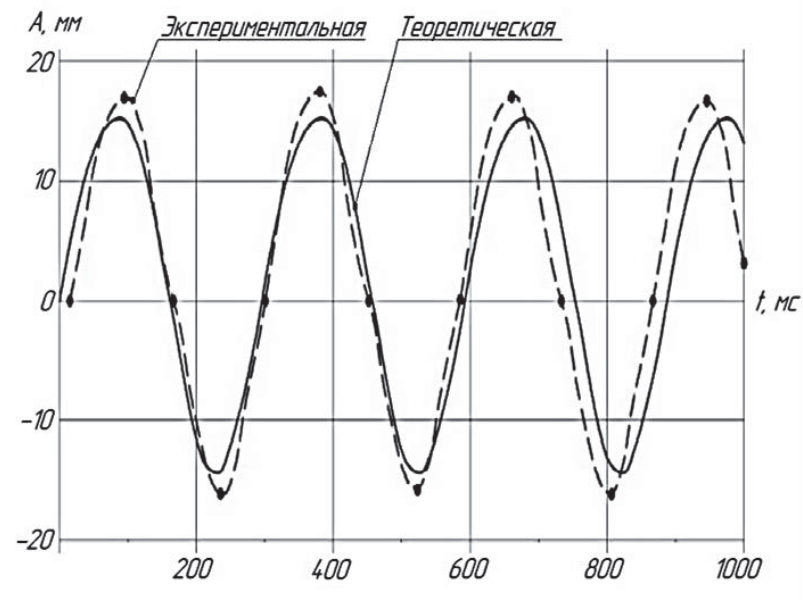

б)

Рисунок 8

Экспериментальная и теоретическая временные зависимости:

a) тока индуктора ДПЛАД; б) амплитуды колебаний ножевых полос режущего аппарата $a$ )

Выводы. Проведено экспериментальное исследование работы режущего аппарата жатки комбайна с линейным электроприводом в лабораторных и полевых условиях. Оценена работоспособность предложенной кинематической схемы. Получены экспериментальные временные зависимости величины тока индуктора
ДПЛАД и амплитуды колебаний ножевых полос. Результаты проведенных экспериментальных исследований не выходят за рамки допустимых значений - 10 \%, в сравнение с теоретическими, что свидетельствуют об адекватности полученной ранее математической модели [5]. 


\section{Библиографический список}

1. Аипов, Р.С. Основы построения и теории линейных асинхронных приводов с упругими накопителями энергии [Текст] / Р.С. Аипов. Уфа: Башкирский ГАУ, 2006. 295 с.

2. Веселовский, О.Н. Линейные асинхронные двигатели [Текст] / О.Н. Веселовский, А.Ю. Коняев, Ф.И. Сарапулов; под общ. ред. О.Н. Веселовского. М.: Энергоатомиздат, 1991. $256 \mathrm{c}$.

3. Вилнитис, А.Я. Концевой эффект в линейных асинхронных двигателях [Текст] / А.Я. Вилнитис, М.С. Дриц. Рига: Зинатке, 1981. 257 с.

4. Кленин, Н.И. Сельскохозяйственные машины [Текст] : учебник для студентов вузов, обуч. по напр. «Агроинженерия» : допущено МСХ РФ / Н.И. Кленин, С.Н. Киселев, А.Г. Левшин. М.: КолосС, 2008. 816 с.

5. Леонтьев, Д.С. Математическая модель линейного электропривода режущего аппарата возвратно-поступательного движения [Текст] / Д.С. Леонтьев // Достижения науки - агропромышленному производству : материалы XLIX Международной научно-технической конференции. Челябинск: Челябинская ГАА, 2010. C. 329-334.

6. Линенко, А.В. Линейные асинхронные электроприводы сложного колебательного движения для технологических машин АПК [Текст] : учебное пособие / А.В. Линенко. Уфа: Башкирский ГАУ, 2015. 183 с.

7. Листопад, Г.Е. Сельскохозяйственные и мелиоративные машины [Текст] / Г.Е. Листопад, Г.К. Демидов, Б.Д. Зонов и др.; под общ. ред. Г.Е. Листопада. М.: Агропромиздат, 1986. 688 с.

8. Ожерельев, В.Н. Современные зерноуборочные комбайны [Текст]: учеб. пособие для студ. вузов, обуч. по спец. «Механизация сельского хозяйства» и «Технология обслуживания и ремонта машин в АПК» : рек. УМО вузов РФ / В.Н. Ожерельев. М.: Колос, 2009. 175 с.

9. Привод режущего аппарата [Текст]: патент на изобретение № 2380882. Российская Федерация, МПК51 A01D 34/30, A01D 34/32, A01D 34/37 / Р.С. Аипов, Д.Е. Валишин, Д.С. Леонтьев, А.В. Линенко; заявитель и патентообладатель ФГОУ ВПО Башкирский ГАУ. № 2008147 456/12; завл. 01.12.2008; опубл. 10.02.2010, бюл. № 4.5 c.

10. Труфляк, Е.В. Современные зерноуборочные комбайны [Текст] : учебное пособие для студентов вузов, обучающихся по направлению «Агроинженерия»/ Е.В. Труфляк, Е.И. Трубилин. 2-е изд., стереотип. Санкт-Петербург Москва - Краснодар: Лань, 2017. 319 с.

11. Халанский, В.М. Сельскохозяйственные машины [Текст] : учеб. для студ. вузов по агрономическим спец. / В.М. Халанский, И.В. Горбачев. М. : КолосС, 2003. 624 с.

12. Резник, Н.Е. Теория резания лезвием и основы расчета режущих аппаратов [Текст] / Н.Е. Резник. М. : Машиностроение, 1975. 311 с.

13. Босой, Е. С. Режущие аппараты уборочных машин (теория и расчет) [Текст] / Е. С. Босой. М. : Машиностроение, 1967. 168 с.

14. Сарапулов, Ф.Н. Основы теории и моделирования линейного асинхронного двигателя как объекта управления [Текст] / Ф.Н. Сарапулов, И.В. Черных. Екатеринбург, 1999. 228 с.

15. Соколов, М.М. Электропривод с линейными асинхронными двигателями [Текст] / М.М. Соколов, Л.К. Сорокин. М.: Энергия, 1974. $136 \mathrm{c}$.

\section{Сведения об авторах}

1. Аипов Рустам Сагитович, доктор технических наук, профессор кафедры электрических машин и электрооборудования, ФГБОУ ВО Башкирский ГАУ, г. Уфа, ул. 50-летия Октября, 34, тел.: (347) 228-36-55.

2. Леонтьев Дмитрий Сергеевич, старший преподаватель кафедры электрических машин и электрооборудования, ФГБОУ ВО Башкирский ГАУ, г. Уфа, ул. 50-летия Октября, 34, e-mail: dimaleon@ mail.ru.

3. Кабашов Владимир Юрьевич, доктор технических наук, профессор кафедры безопасности жизнедеятельности и технологического оборудования, ФГБОУ ВО Башкирский ГАУ, г. Уфа, ул. 50-летия Октября, 34, тел.: (347) 228-07-17.

Статья посвящена разработке и исследованию экспериментальной установки электропривода двухножевого режущего аппарата жатки зерноуборочного комбайна. Приведена компоновка элементов жатки комбайна, режущий аппарат которой снабжается электроприводом на основе двухсторонних плоских линейных асинхронных двигателей. Составлена кинематиче- ская схема линейного электропривода режущего аппарата, оценена ее работоспособность в лабораторных условиях. Выявлено, что для эффективности режущего аппарата предпочтительной является работа приводных асинхронных двигателей в режиме вынужденных колебаний. При этом исключаются датчики положения и появляется возможность настраивать параметры ко- 
лебаний ножевых полос согласно технологическому процессу резания. Также проведено исследование линейного электропривода режущего аппарата жатки комбайна в полевых условиях. Для этого разработанный и испытанный в лабораторных условиях тиристорный блок коммутации и управления работой линейных асинхронных электродвигателей, позволяющий оптимально настраивать параметры колебательного процесса ножевых полос для конкретных условий уборки, подключался к мобильной дизель-генераторной установке. При этом экспериментально были получены временные зависимости величины токов индукторов двухсторонних плоских линейных асинхронных двигателей и амплитуды колебаний ножевых полос режущего аппарата. При сравнении тока, потребляемого индукторами линейных двигателей по максимальной амплитуде и длительности импульса, сделаны выводы о том, что при работе линейного электропривода режущего аппарата в установившемся режиме различие по току составляет не более 8,8 \% по отношению к ранее полученным теоретическим данным. Совмещение экспериментальной временной зависимости амплитуды колебаний ножевых полос режущего аппарата с теоретической позволяет сделать вывод о том, что отличие амплитуды колебаний не выходит за пределы 8,4 \%. Все это свидетельствует об адекватности ранее полученной математической модели.

R. Aipov, D. Leontiev, V. Kabashov

\title{
EXPERIMENTAL STUDY OF LINEAR ELECTRIC DRIVE OF THE DOUBLE-BREED CUTTING MACHINE OF THE GRAIN COMBINE HEADER
}

\author{
Key words: linear electric drive; reciprocating motion; cutting apparatus; knife strip; flat linear asyn- \\ chronous motor; inductor; secondary element.
}

\section{Authors' personal details}

1. Aipov Rustam, Doctor of Technical Sciences, Professor, Head of the Electric Machinery and Equipment Chair, Federal State Budgetary Educational Institution of Higher Education «Bashkir State Agrarian University», 34, 50-letiya Octyabrya Str., Ufa, 450001, phone: (347) 228-36-55.

2. Leontiev Dmitry, senior Lecturer, Head of the Electric Machinery and Equipment Chair, Federal State Budgetary Educational Institution of Higher Education «Bashkir State Agrarian University», 34, 50-letiya Octyabrya Str., Ufa, 450001, e-mail: dimaleon@mail.ru.

3. Kabashov Vladimir, Doctor of Technical Sciences, Professor, Department of Life Safety and Technological Equipment, Federal State Budgetary Educational Institution of Higher Education «Bashkir State Agrarian University», 34, 50-letiya Octyabrya Str., Ufa, 450001, phone: (347) 228-36-55.

The article is devoted to the development and research in the work of an experimental installation of an electric drive of a two-blade cutting apparatus of a combine harvester harvester. The layout of the combine harvester elements is given, the cutting apparatus of which is supplied with electric drive based on two-sided flat linear asynchronous motors. The kinematic diagram of the linear electric drive of the cutting apparatus was compiled, its efficiency was evaluated in laboratory conditions. It was revealed that for efficient operation of the cutting apparatus, the operation of drive induction motors in the mode of forced oscillations is preferable. This eliminates the position sensors and it is possible to adjust the parameters of the oscillations of the knife strips according to the technological process of cutting. A study was also made of the linear electric drive of the cutting apparatus of the combine harvester in field conditions. For this purpose, a thyristor switching and control unit for linear asynchronous electric motors, designed and tested under la- boratory conditions, which allows optimally adjusting the parameters of the oscillating process of knife strips for specific harvesting conditions, was connected to a mobile diesel generator set. In this case, the time dependences of the currents of inductors of two-sided flat linear asynchronous motors and the amplitude of oscillations of the blade strips of the cutting apparatus were experimentally obtained. When comparing the current consumed by inductors of linear motors by the maximum amplitude and pulse duration, it was concluded that when the linear electric drive of the cutting unit operates in a steady state, the current difference is no more than $8,8 \%$ compared to the previously obtained theoretical data. The combination of the experimental time dependence of the oscillation amplitude of the knife strips of the cutting apparatus with the theoretical one allows us to conclude that the difference in the amplitude of oscillations does not go beyond 8,4\%. All this testifies to the adequacy of the previously obtained mathematical model.

(C) Аипов Р.С., Леонтьев Д.С., Кабашов В.Ю. 
УДК 621.316 .13

DOI: $10.31563 / 1684-7628-2019-51-3-83-92$

Л.П. Андрианова, В.Ю. Кабашов, Д.С. Хайрисламов

\section{ИНДИКАТИВНЫЕ ПОКАЗАТЕЛИ НАДЕЖНОСТИ SAIFI И SAIDI СЕЛЬСКИХ ЭЛЕКТРИЧЕСКИХ СЕТЕЙ С ИНТЕЛЛЕКТУАЛЬНЫМИ СЕКЦИОНИРУЮЩИМИ РЕКЛОУЗЕРАМИ}

\section{Ключевые слова: сельские электрические сети; надежность электроснабжения; кольцевой фидер; секционирование; интеллектуальные реклоузеры; индикативные показатели.}

Введение. Низкая надежность электроснабжения сельских потребителей, наличие участков, проходящих в лесистой местности, частые повреждения и длительное время их поиска в воздушных распределительных электрических сетях среднего класса напряжений $(6,10,20$, 35 кВ) [8, 9], обуславливают необходимость перехода к сетям нового технологического уклада с качественно новыми характеристиками надежности, эффективности, доступности и управляемости [1-3]. В соответствии с положением ПАО «Россети» «О единой технической политике в электросетевом комплексе» программой инновационного развития электросетевого комплекса предусматривается внедрение в сетях среднего класса напряжений перспективных технологий на основе интеллектуальных коммутационных аппаратов - реклоузеров. Реклоузер - интеллектуальное устройство автоматического управления и защиты воздушных линий электропередач, выполненное на базе вакуумных выключателей [7].

Цель исследования - анализ методики количественной оценки показателей надежности сельских распределительных электрических сетей 6-35 кВ с секционирующими реклоузерами в соответствии с требованиями действующих законодательно-нормативных документов.

Методика проведения исследования. Повышение надежности электроснабжения сельских распределительных сетей 6-35 кВ, оснащенных секционирующими интеллектуальными реклоузерами, обеспечивается за счет [5, 6]: секционирования сети, что позволяет локализовать поврежденные участки, сохраняя при этом электроснабжение остальных потребителей питающего фидера и подавая питание на неповрежденный участок от резервного источника питания $[15,16]$; сокращения времени обслуживания, ремонта, так как секционирование сети позволяет уменьшить время определения поврежденного участка фидера и его локализацию; наблюдаемости сети с помощью автоматизированных информационно-измерительных систем контроля качества и учета электроэнергии, мониторинга параметров ЛЭП, автоматизации учёта отключений и формирования статистики повреждений и пр. [14]; управляемости сети путем управления отдельными коммутационными аппаратами и ведения режима сети дистанционно из SCADA системы и по месту $[1,12]$. Реклоузеры могут устанавливаться на одной или двух опорах [5-7]. Общий вид реклоузера показан на рисунке 1 . В состав реклоузера входят коммутационный модуль со встроенными датчиками тока, напряжения и шкафом управления, трехфазные разъединители, ограничители перенапряжений и изоляторы. Повышение надежности электроснабжения потребителей радиального и кольцевого фидера может быть обеспечено включением реклоузеров, как показано на рисунке 2. Реклоузер R2 устанавливается в точку нормального разрыва кольцевого фидера, обеспечивая функцию автоматического включения резерва $[5-7,17]$. Для повышения уровня надежности ответственных потребителей количество и места установки реклоузеров рекомендуется выбирать так, чтобы ответственный потребитель был подключен к участку сети наименьшей протяженности (рисунок 3 ). На рисунке 4 показано место установки реклоузера R1 в случае необходимости подключения нового потребителя и (или) разграничения балансовой принадлежности $[5,6,11]$. Наличие реклоузера R1 в точке подключения нового потребителя или разграничения балансовой принадлежности не ухудшает надежность фидера в целом и обеспечивает сохранение текущих показателей надежности. Выбор оптимального количества реклоузеров осуществляется по показателям эффективности реконструкции сети RNRE и ARAE $[3,5,6]$.

Результаты исследований. На рисунке 5 показана зависимость показателей RNRE и ARAE от количества устанавливаемых реклоузеров для радиального фидера.

Показатель RNRE характеризует относительную эффективность реконструкции сети и показывает, насколько снижается среднее количество отключений потребителей в год после установки реклоузеров по сравнению с ситуацией до установки реклоузеров. 


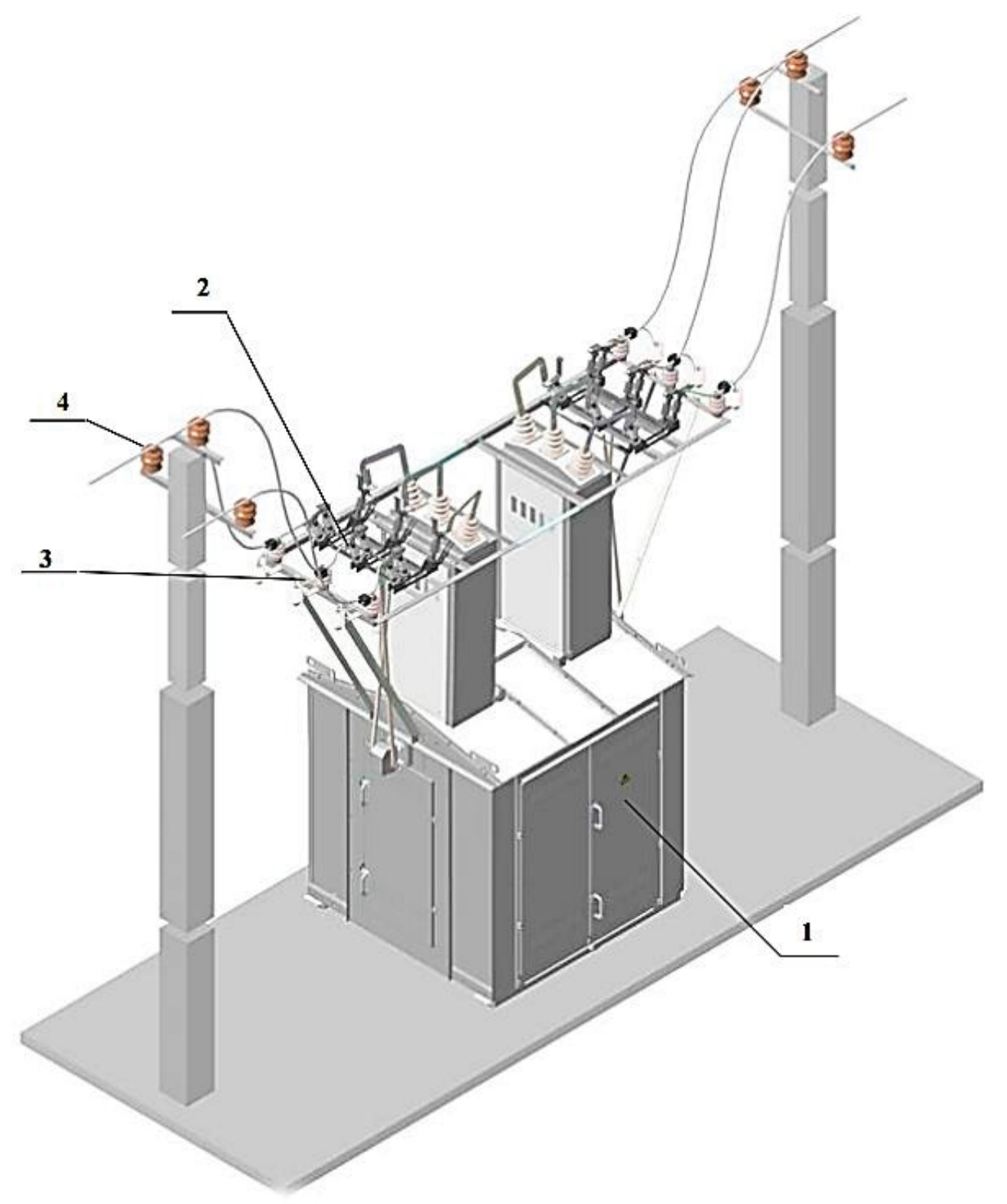

Рисунок 1

Общий вид реклоузера:

1 - коммутационный модуль со встроенными датчиками тока, напряжения и шкафом управления (1 шт.), 2 - разъединитель 3-фазный (2 шт.) 3 - ограничитель перенапряжений (6 шт.), 4 - изолятор (6 шт.)

\section{Подстанция}
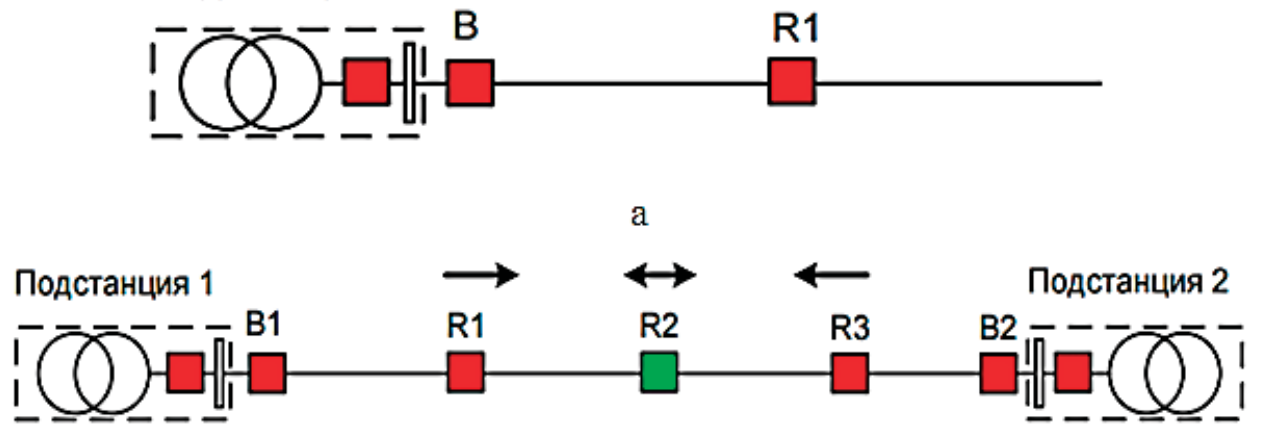

Рисунок 2

Установка реклоузеров: а - радиальный фидер; б - кольцевой фидер; В, В1, В2 - выключатели; R1, R2, R3 - реклоузеры 


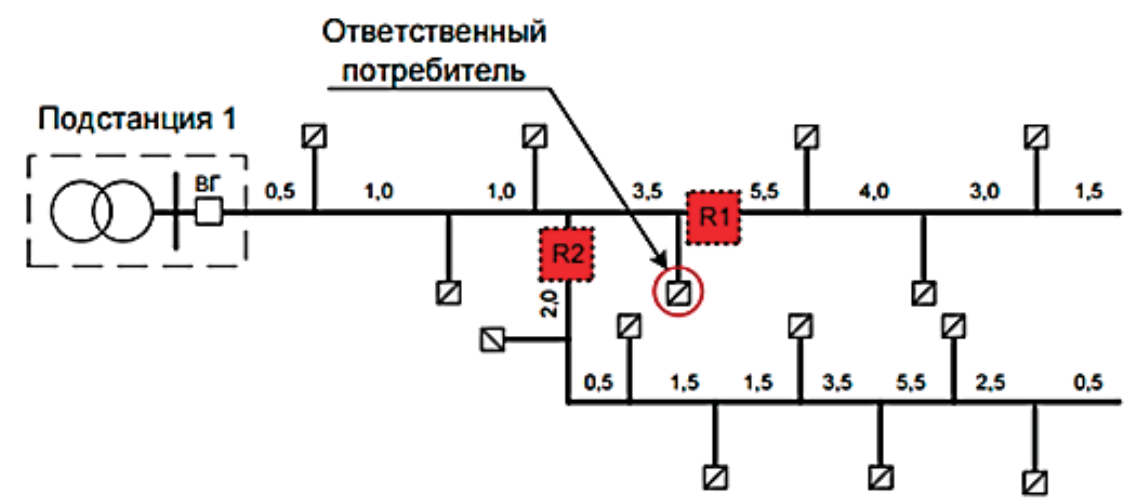

a

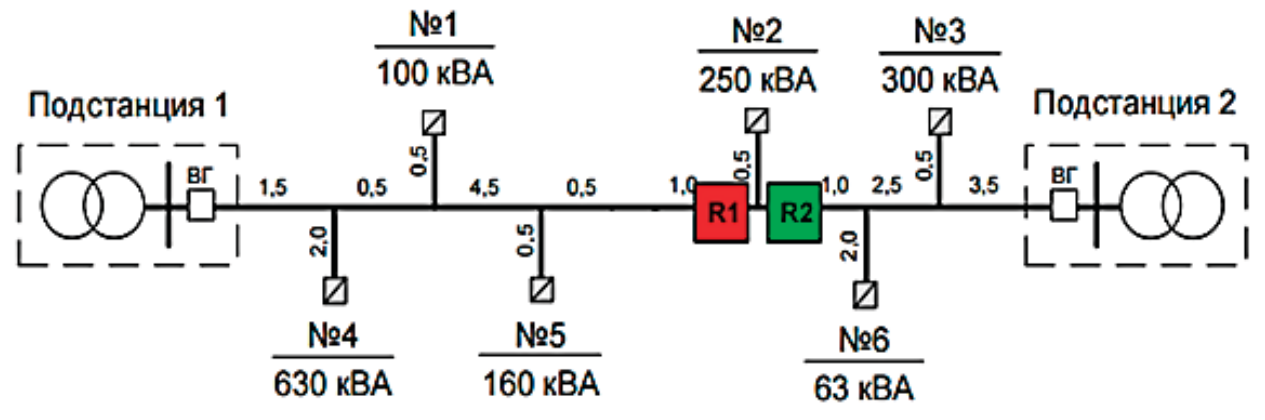

б

Рисунок 3

Установка реклоузеров R1, R2:

$\mathrm{a}$ - на радиальном фидере; б - на кольцевом фидере

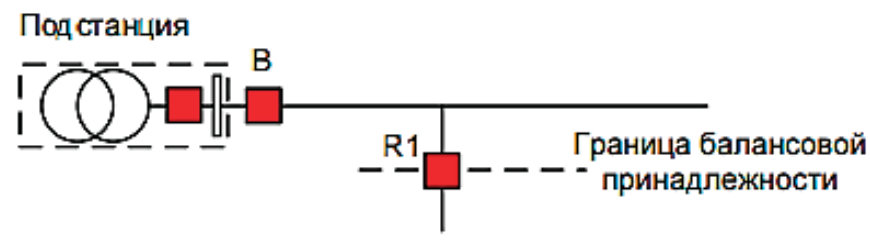

Рисунок 4

Установка реклоузеров для подключения новых потребителей:

В - выключатель; R1 - реклоузер

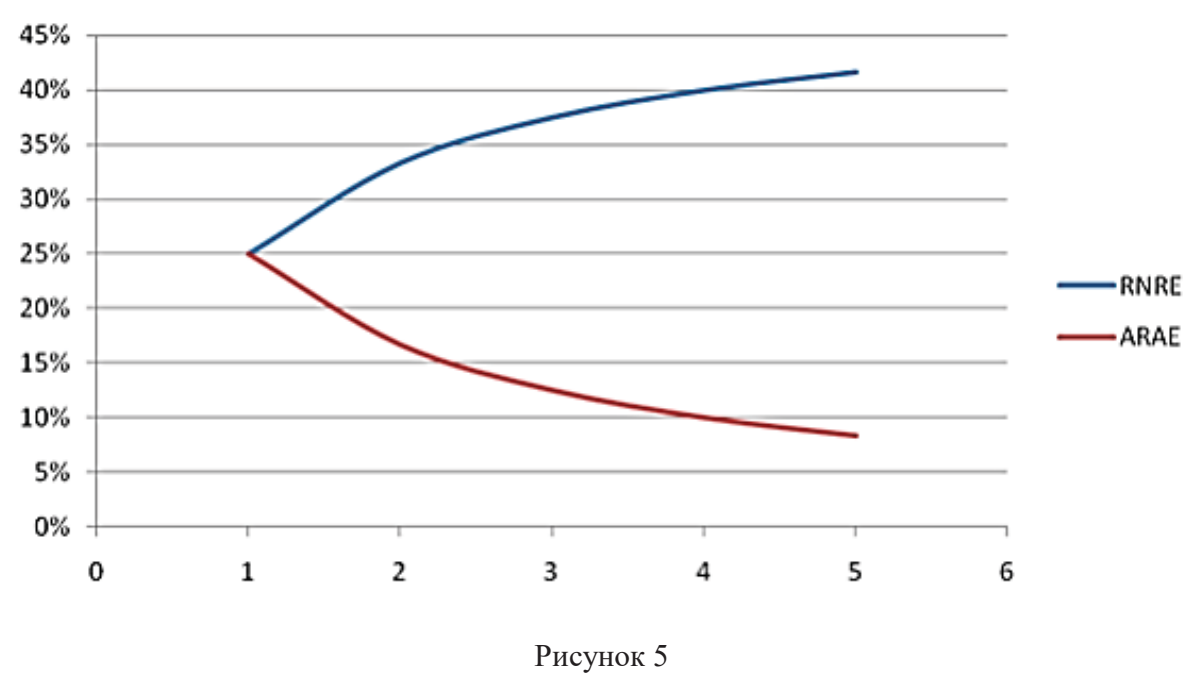

Зависимость показателей RNRE и ARAE от количества устанавливаемых реклоузеров для радиального фидера [5, рисунок 3.8] 


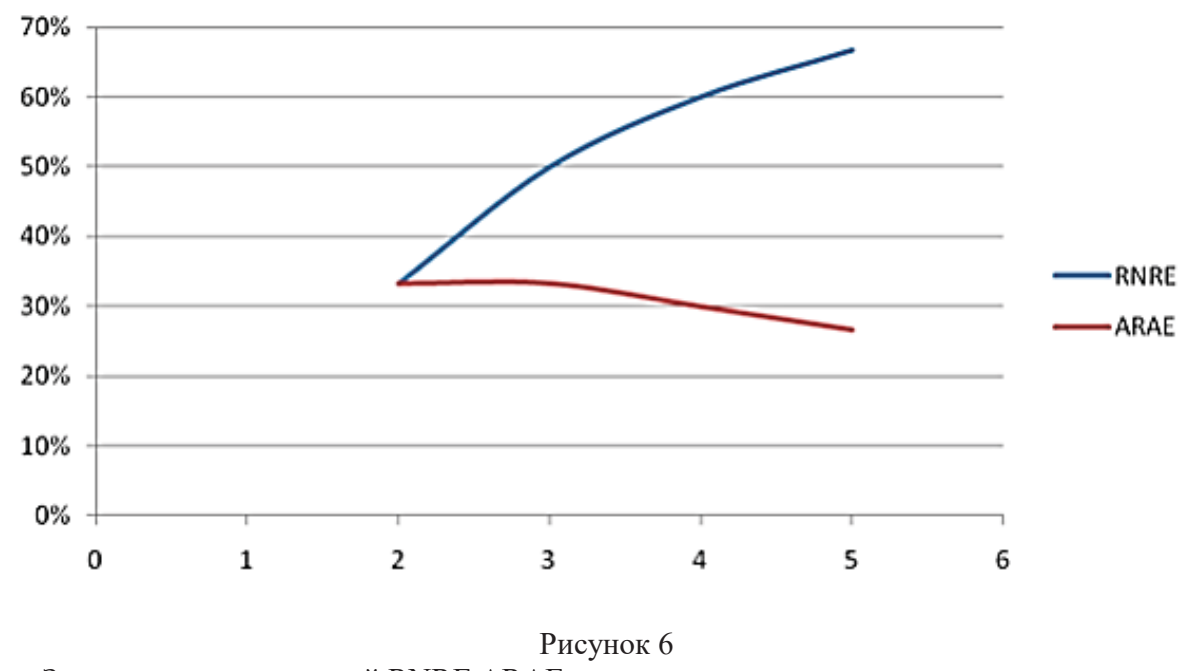

Зависимость показателей RNRE ARAE от количества устанавливаемых реклоузеров кольцевого фидера [5, рисунок 3.9]

Показатель ARAE характеризует среднюю эффективность инвестиций и показывает, сколько инвестиций требуется вложить в реконструкцию сети при установке реклоузеров для увеличения показателя RNRE на $1 \%[5,13]$. Из зависимости, приведенной на рисунке 5 , следует, что средняя эффективность применения реклоузеров на радиальном фидере уменьшается, начиная с одного аппарата, и следовательно, оптимальным вариантом является установка 1-2 реклоузеров. На рисунке 6 показана зависимость показателей RNRE и ARAE от количества устанавливаемых реклоузеров для кольцевого фидера.

Анализ зависимостей, приведенных на рисунке 6, показывает, что средняя эффективность применения реклоузеров на фидере уменьшается, начиная с трёх аппаратов, и следовательно, оптимальным вариантом для кольцевого фидера является установка 3-4 реклоузеров. Из проведенного анализа следует, что эффективнее применять реклоузеры на кольцевых фидерах [5]. В соответствии с приказами Министерства энергетики РФ $[2,3]$ оценка уровня надежности и качества электроснабжения распределительной сети осуществляется по индикативным показателям надежности (SAIFI и SAIDI).

Показатель надежности SAIFI (System Average Interruption Frequency Index - средняя частота появления повреждений в системе) характеризует среднее количество отключений потребителей в год (откл./год) [3, 10]:

$$
\text { SAIFI }=\sum\left(\omega_{i} \cdot N_{i}\right) / \sum N_{i}
$$

где $\omega_{i}-$ количество отключений потребителей $i$-го участка фидера, откл./год; $N_{i}-$ количество потребителей $i$-го участка фидера, шт.; $i$ - количество участков фидера, шт.,

$$
\omega_{i}=0,01 \cdot \omega_{0} \cdot\left(1-k_{\mathrm{Hy}}\right) \cdot L_{i},
$$

где $\omega_{0}$ - удельная частота повреждений на 100 км линии, откл./год; $k_{\text {ну }}$ коэффициент, учитывающий наличие многократных АПВ на устранение неустойчивых повреждений в сети: $k_{\text {ну }}=0$ при отсутствии АПВ; $k_{\text {ну }}=0,6$ при наличии однократного АПВ; $k_{\text {ну }}=0,8$ при наличии двукратного АПВ; $L_{i}$ - суммарная длина участков фидера, при повреждении на которых происходит отключение потребителей $i$-го участка, км:

$$
\omega_{0}=n_{\text {откл }} \cdot 100 / L \text {, }
$$

где $n_{\text {откл }}-$ количество отключений фидера в год, откл./год; $L$ - длина линии, км.

Показатель надежности SAIDI (System Average Interruption Duration Index - средняя продолжительность отключения) характеризует в среднем продолжительность одного отключения в системе в год (ч/год) $[3,10]$ :

$$
S A I D I=\sum\left(T_{i} \cdot N_{i}\right) / \sum N_{i},
$$

где $T_{i}$ - время перерыва электроснабжения потребителей $i$-го участка фидера, ч/год,

$$
T_{i}=\omega_{i} \cdot T \cdot k_{\mathrm{BB}}
$$

где $T$ - среднее время восстановления одного устойчивого повреждения, ч; $k_{\text {вв }}-$ коэффициент, учитывающий влияние сокращения зоны поиска поврежденного участка за счет секционирования на общее время восстановления электроснабжения, при наличии автоматических пунктов секционирования принимается равным $k_{\text {вв }}=$ 0,6 .

$$
T=T_{\text {пер. }} \cdot n_{\text {откл. }},
$$

где $T_{\text {пер. }}-$ общее время перерыва электроснабжения при аварийных отключениях фидера (ч/год); $n_{\text {откл. }}$ - количество аварийных отключений фидера, приводящих к перерыву электроснабжения (откл./год).

Выбор мест установки интеллектуальных реклоузеров осуществляется по критерию минимального значения показателя SAIFI. Мини- 
мальное значение SAIFI достигается при равенстве произведения количества потребителей $(N)$ на протяжённость фидера $(L)$ со всеми отпайками на каждом из участков сети [5].

$$
N_{i} \cdot L_{i} \approx \text { const }
$$

где $N_{i}$ - количество потребителей, подключённых к участку $i ; L_{i}-$ суммарная протяжённость фидера с отпайками на участке $i$, км.

Методика определения уровня надежности сети по индикативным показателям SAIFI и SAIDI до и после установки секционирующих пунктов - реклоузеров рассмотрена на примере кольцевого фидера. С целью повышения надежности электроснабжения потребителей предусматривается установка секционирующих реклоузеров и организация двукратного автома- тического повторного включения (АПВ) и защиты минимального напряжения (3МН) на головных выключателях кольцевого фидера $[5,6]$. Схемы кольцевого фидера до и после установки реклоузеров приведены соответственно на рисунках 7 и 8.

В таблице 1 указаны длины участков фидера, номера и количество потребителей, получающих питание от подстанций 1 и 2. В таблице 2 приведены значения удельной частоты повреждений на 100 км линии в год, среднее время восстановления одного устойчивого повреждения и информация о наличии или отсутствии АПВ на головном выключателе участков фидера, необходимые для расчета индикативных показателей SAIFI и SAIDI.

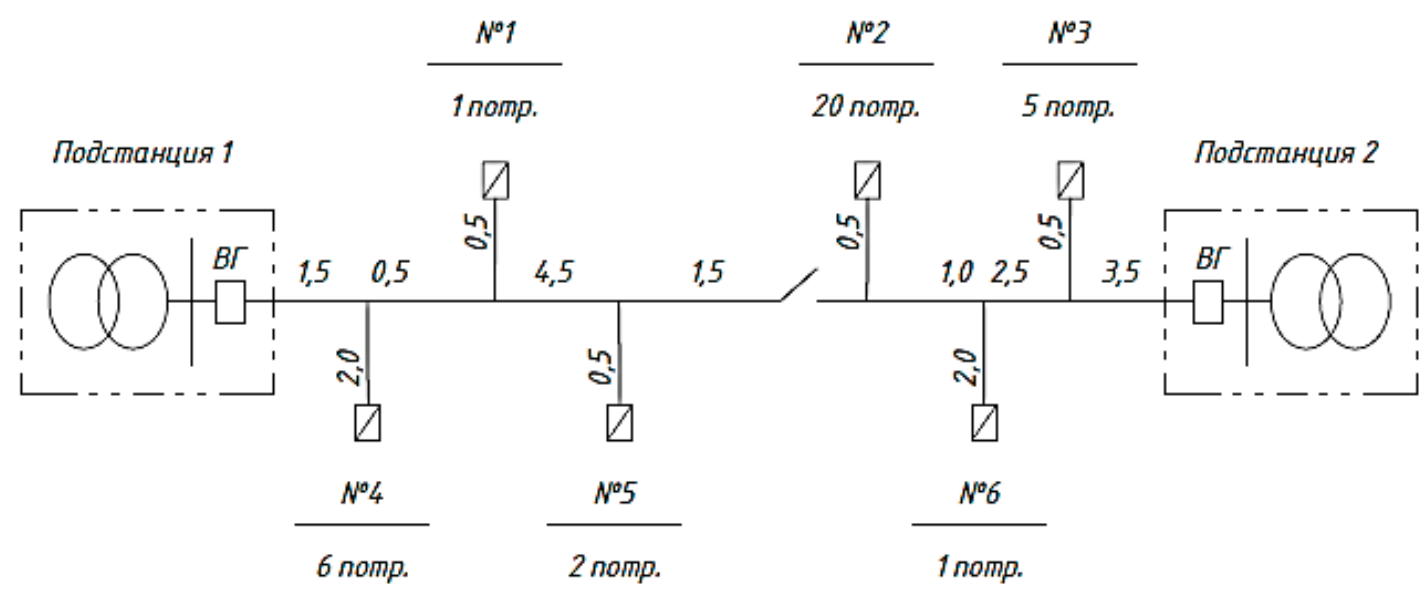

Рисунок 7

Схема кольцевого фидера до установки реклоузеров: № 1, № 4, № 5 - номера потребителей линии 1 от подстанции 1; № 2, № 3, № 6 - номера отпаек линии 2 от подстанции 2

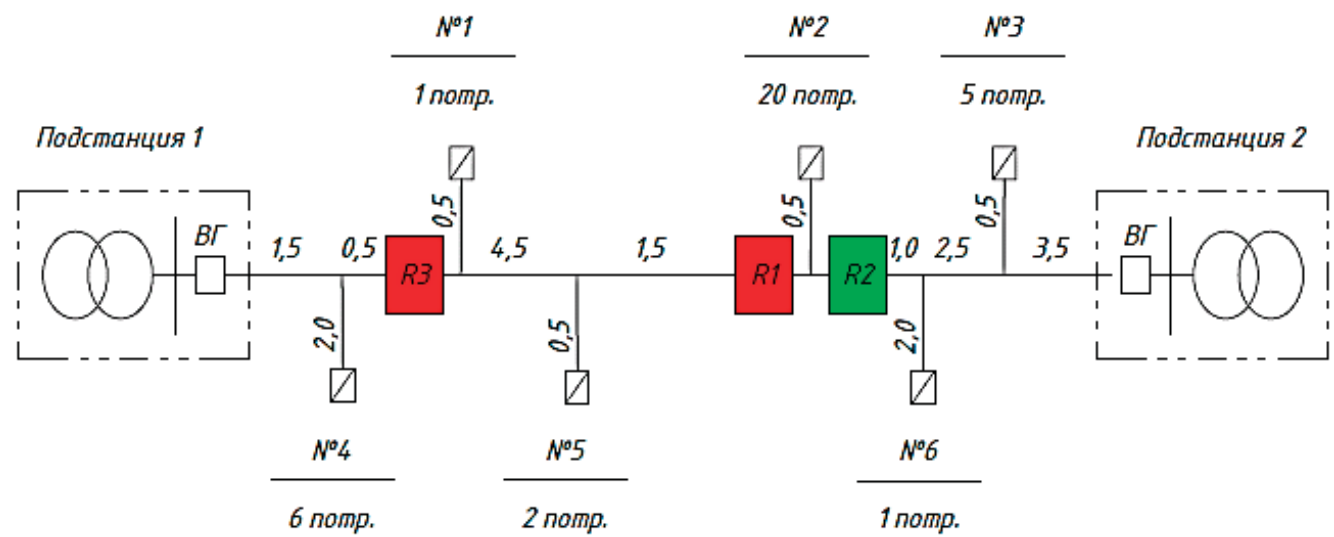

Рисунок 8

Схема кольцевого фидера после установки реклоузеров: R1, R2, R3 - реклоузеры

Таблица 1 Длины участков, номера и число потребителей на участках

\begin{tabular}{|c|c|c|}
\hline Номер участка, номер потребителя & Количество потребителей, $N$, шт. & Длина участка, км \\
\hline 1, № 4 & $N_{1}=6$ & $L_{1}=1,5+0,5+2,0=4$ \\
\hline 2, № 1, № 5 & $N_{2}=1+2=3$ & $L_{2}=0,5+4,5+1,5+0,5=7$ \\
\hline 3, № 2 & $N_{3}=20$ & $L_{3}=0,5$ \\
\hline 4, № 3, № 6 & $N_{4}=1+5=6$ & $L_{4}=1,0+2,0+2,5+0,5+3,5=9,5$ \\
\hline & $N_{\Sigma}=35$ & $L_{\Sigma}=20$ \\
\hline
\end{tabular}


Таблица 2 Исходные данные для расчета

\begin{tabular}{|c|c|c|c|}
\hline Фидер & $\begin{array}{c}\text { Удельная частота повреждений } \\
\text { на } 100 \text { км линии в год, откл. }\end{array}$ & $\begin{array}{c}\text { Среднее время восстановления одного } \\
\text { устойчивого повреждения, ч }\end{array}$ & $\begin{array}{c}\text { АПВ } \\
\text { на головном выключателе }\end{array}$ \\
\hline 1 (участки 1,2) & 30 & 6 & однократное \\
\hline 2 (участки 3,4) & 40 & 6 & отсутствует \\
\hline
\end{tabular}

Для расчета показателей надежности SAIFI и $S A I D I$ кольцевой фидер разбит на участки $1-4$, как показано на рисунке 9. Расчет показателя SAIFI на участках 1, 2 фидера до установки реклоузеров проводится по формуле (откл./год):

$$
\omega_{i}=0,01 \cdot \omega_{0} \cdot\left(1-k_{\mathrm{Hy}}\right) \cdot\left(L_{1}+L_{2}\right),
$$

где $\omega_{1(2)}-$ количество отключений потребителей 1 и 2 участков (откл./Год); $\omega_{0}$ - удельная частота повреждений на 100 км линии в год, $\omega_{0}=30 ; k_{\text {ну }}$ - коэффициент, учитывающий наличие АПВ на головном выключателе, о.е., $k_{\text {ну }}=0,6$, т. к. на головном выключателе имеется однократное АПВ и по статистике снижающее количество отключений потребителей при неустойчивых повреждениях на $60 \%[5,6] ; L_{1}, L_{2}$ - длина первого и второго участков, км,

$$
\begin{gathered}
\omega_{1(2)}=0,01 \cdot 30 \cdot(1-0,6) \cdot(1,5+0,5+2,0+ \\
+0,5+4,5+0,5+1,5)=1,3 \text { (откл./год). }
\end{gathered}
$$

Расчет показателя SAIFI - количества отключений потребителей на участках 3 и 4 проводится по формуле (откл./год):

$$
\omega_{3(4)}=0,01 \cdot \omega_{0} \cdot\left(1-k_{\text {ну }}\right) \cdot\left(L_{3}+L_{4}\right),
$$

где $\omega_{3(4)}-$ количество отключений потребителей 3 и 4 участков (откл./год); $\omega_{0}-$ удельная частота повреждений на 100 км линии в год, $\omega_{0}=40 ; k_{\text {ну }}$ - коэффициент, учитывающий наличие АПВ на головном выключателе, о.е., $k_{\text {ну }}=0$, т. к. на головном выключателе отсутствует АПВ; $L_{3}, L_{4}-$ длина 3 и 4 участков, км;

$$
\begin{gathered}
\omega_{3(4)}=0,01 \cdot 40 \cdot(1-0) \cdot(0,5+1,0+2,0+ \\
+2,5+0,5+3,5) \approx 4,0 \text { (откл./год). }
\end{gathered}
$$

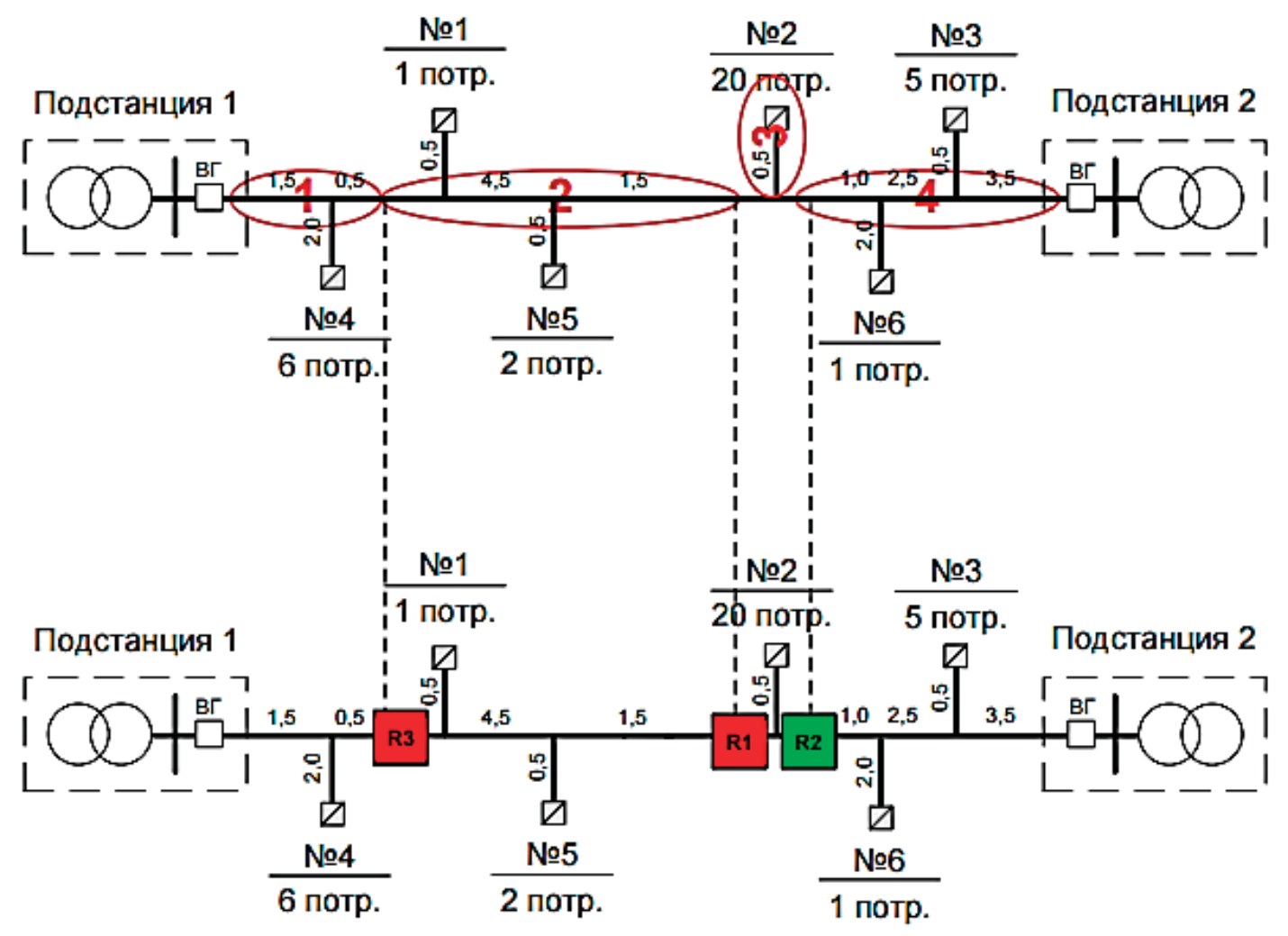

Рисунок 9

Схема кольцевого фидера с разделением на участки

Результирующий показатель SAIFI $\sum 1$ (откл./ год) до установки реклоузеров согласно (1):

$\operatorname{SAIFI~} \sum 1=\sum\left(\omega_{i} \cdot N_{i}\right) / \sum N_{i}=3,3$ (откл./год);

$$
\sum\left(\omega_{i} \cdot N_{i}\right)=\left(\omega_{1} \cdot N_{1}+\omega_{2} \cdot N_{2}+\right.
$$$$
\left.+\omega_{3} \cdot N_{3}+\omega_{4} \cdot N_{4}\right)=115,7 \text { (откл./Год); }
$$

$$
\sum N_{i}=\left(N_{1}+N_{2}+N_{3}+N_{4}\right)=35 \text {, }
$$

где $\omega_{i}-$ количество отключений потребителей $i$-го участка (откл./год); $N_{i}$ - количество потребителей на $i$-м участке; $N_{1}, N_{2}, N_{3}, N_{4}$ - число потребителей на 1-4 участках соответственно.

Расчет времени перерыва электроснабжения (показатель $S A I D I$ ) потребителей на участках 1 , 
2, 3, 4 до установки реклоузеров согласно (5) (ч/год):

$$
T_{i}=\omega_{i} T_{\mathrm{cp}} k_{\mathrm{Bв}}
$$

где $\omega_{i}-$ количество отключений потребителей на $i$-м участке; $T_{\mathrm{cp}}-$ среднее время восстановления одного устойчивого повреждения, $T_{\mathrm{cp}}=6$ ч; $k_{\mathrm{BB}}-$ коэффициент, учитывающий наличие или отсутствие секционирования, при отсутствии секционирования $k_{\mathrm{BB}}=1,0$;

$$
\begin{gathered}
T_{1(2)}=1,3 \cdot 6 \cdot 1=7,8 \text { ч/год; } \\
T_{3(4)}=4 \cdot 6 \cdot 1=24 \text { ч/год. }
\end{gathered}
$$

Результирующий показатель $S A I D I \sum 1$ (ч/год) согласно (4) до установки реклоузеров:

$$
\begin{gathered}
\text { SAIDI } \sum 1=\sum\left(T_{i} \cdot N_{i}\right) / \sum N_{i}=19,8 \text { (ч/год); } \\
\sum\left(T_{i} \cdot N_{i}\right)=\left(T_{1} \cdot N_{1}+T_{2} \cdot N_{2}+\right. \\
\left.+T_{3} \cdot N_{3}+T_{4} \cdot N_{4}\right)=694,2(\text { ч/ год); } \\
\sum N_{i}=\left(N_{1}+N_{2}+N_{3}+N_{4}\right)=35 .
\end{gathered}
$$

Расчет количества отключений потребителей фидера (откл./год) согласно (2) после установки реклоузеров:

- участок 1 :

$$
\begin{gathered}
\omega_{1}=0,01 \cdot \omega_{0} \cdot\left(1-k_{\mathrm{Hy}}\right) \cdot L_{1}, \\
\omega_{1}=0,01 \cdot 30 \cdot(1-0,8) \cdot \\
\cdot(1,5+0,5+2,0)=0,23 \text { (откл./год). }
\end{gathered}
$$

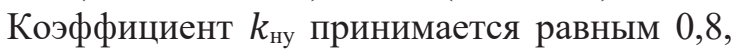
т. к. на головном выключателе и реклоузерах имеется двукратное АПВ и, по статистике, снижающее количество отключений потребителей при неустойчивых повреждениях на 80 \% [4].

- участок 2 :

$$
\begin{gathered}
\omega_{2}=0,01 \cdot \omega_{0} \cdot\left(1-k_{\mathrm{Hy}}\right) \cdot L_{2}, \\
\omega_{2}=0,01 \cdot 30 \cdot(1-0,8) \cdot
\end{gathered}
$$

$\cdot(0,5+4,5+0,5+1,5)=0,43$ (откл./год);

- участок 3 :

$$
\omega_{3}=0,01 \cdot \omega_{0} \cdot\left(1-k_{\text {ну }}\right) \cdot L_{3},
$$

$\omega_{3}=0,01 \cdot 40 \cdot(1-0,8) \cdot 0,5=0,04$ (откл./год);

- участок 4 :

$$
\begin{gathered}
\omega_{4}=0,01 \cdot \omega_{0} \cdot\left(1-k_{\mathrm{Hy}}\right) \cdot L_{4}, \\
\omega_{4}=0,01 \cdot 40 \cdot(1-0,8) \cdot(1,0+2,0+ \\
+2,5+0,5+3,5)=0,7 \text { (откл./год). }
\end{gathered}
$$

Результирующий показатель $S A I F I \sum 2$ после установки реклоузеров:

$$
\begin{gathered}
\text { SAIFI } \sum 2=\sum\left(\omega_{i} \cdot N_{i}\right) / \sum N_{i}=0,21 \text { (откл./год); } \\
\sum\left(\omega_{i} \cdot N_{i}\right)=(0,23 \cdot 6+0,43 \cdot(1+2)+ \\
+0,04 \cdot 20+0,7 \cdot(5+1))=7,67 \text { (откл./год); } \\
\sum N_{i}=\left(N_{1}+N_{2}+N_{3}+N_{4}\right)=35 .
\end{gathered}
$$

Показатель $S A I D I$ после установки реклоузеров определяется согласно (4) с коэффициентом $k_{\mathrm{Bв}}=0,6$, учитывающим сокращение зоны поиска поврежденного участка за счет секционирования:

- участок $1: T_{1}=0,23 \cdot 6 \cdot 0,6=0,8$ (ч/год);

- участок $2: T_{2}=0,43 \cdot 6 \cdot 0,6=1,5$ (ч/год);

- участок $3: T_{3}=0,04 \cdot 6 \cdot 0,6=0,14($ ч/год);

- участок 4: $T_{4}=0,7 \cdot 6 \cdot 0,6=2,5$ (ч/год).

Результирующий показатель $S A I D I \sum 2$ (ч./год), согласно (4) после установки реклоузеров:

$$
\begin{gathered}
\text { SAIDI } \sum 2=\sum\left(T_{i} \cdot N_{i}\right) / \sum N_{i}=0,75(\mathrm{ч} / \text { год }) ; \\
\sum\left(T_{i} \cdot N_{i}\right)=(0,8 \cdot 6+1,5 \cdot(1+2)+ \\
+0,1 \cdot 20+2,5 \cdot(5+1))=26,3(\mathrm{ч} / \text { год }) ; \\
\sum N_{i}=\left(N_{1}+N_{2}+N_{3}+N_{4}\right)=35 .
\end{gathered}
$$

Расчетные значения показателей надежности SAIFI и SAIDI на участках кольцевого фидера до и после установки реклоузеров приведены в таблице 3. Значения результирующих показателей надежности SAIFI и SAIDI фидера до и после установки реклоузеров приведены в таблице 4. Как видно из таблицы 3 , количество и длительность отключений на всех участках кольцевого фидера снижается после установки реклоузеров R1, R2, R3. Значительное снижение этих показателей соответственно в 100 и 171 раз наблюдается на участке 3 , от которого получают питание 20 потребителей, т. к. на этом участке, кроме секционирующего реклоузера R1, установлен также реклоузер R2, выполняющий функции автоматического включения резерва. Расчетные значения результирующих индикативных показателей $S A I F I$ и $S A I D I$ в кольцевом фидере заданной конфигурации значительно ниже после установки реклоузеров. Повышенный уровень надежности потребителей фидера обусловлен снижением количества и длительности перерывов электроснабжения за год в 15 и 26 раз соответственно.

Таблица 3 Количество и длительность отключений на участках фидера до и после установки реклоузеров

\begin{tabular}{|c|c|c|c|c|c|}
\hline \multicolumn{2}{|c|}{$\begin{array}{c}\text { Показатель } S A I F I-\text { количество отключений } \\
\text { на участках фидера, } \omega_{i}, \text { откл./год }\end{array}$} & \multicolumn{3}{|c|}{$\begin{array}{c}\text { Показатель } S A I D I-\text { длительность отключений } \\
\text { на участках фидера, } T_{i}, \text { ч/год }\end{array}$} \\
\hline $\begin{array}{c}\text { до } \\
\text { установки } \\
\text { реклоузера }\end{array}$ & $\begin{array}{c}\text { после } \\
\text { установки } \\
\text { реклоузера }\end{array}$ & $\begin{array}{c}\text { снижение } \\
\text { показателя } S A I F I, \\
\text { раз }\end{array}$ & $\begin{array}{c}\text { до } \\
\text { установки } \\
\text { реклоузера }\end{array}$ & $\begin{array}{c}\text { после } \\
\text { установки } \\
\text { реклоузера }\end{array}$ & $\begin{array}{c}\text { снижение } \\
\text { показателя } S A I D I, \\
\text { раз }\end{array}$ \\
\hline$\omega_{1}=1,3$ & $\omega_{1}=0,23$ & 5,65 & $T_{1}=7,8$ & $T_{1}=0,8$ & 9,75 \\
\hline$\omega_{2}=1,3$ & $\omega_{2}=0,43$ & 3,02 & $T_{2}=7,8$ & $T_{2}=1,5$ & 5,2 \\
\hline$\omega_{3}=4,0$ & $\omega_{3}=0,04$ & 100 & $T_{3}=24$ & $T_{3}=0,14$ & 171 \\
\hline$\omega_{4}=4,0$ & $\omega_{4}=0,7$ & 5,7 & $T_{4}=24$ & $T_{4}=2,5$ & 9,6 \\
\hline
\end{tabular}


Таблица 4 Сравнительный анализ показателей SAIFI и SAIDI до и после установки реклоузеров

\begin{tabular}{|c|c|c|c|c|c|}
\hline \multicolumn{2}{|c|}{ Результирующие показатели SAIFI } & \multicolumn{3}{|c|}{ Результирующие показатели $S A I D I$} \\
(количество отключений потребителей), откл./год & \multicolumn{2}{|c|}{ (длительность отключений потребителей), ч/год } \\
\hline до & после & уменьшение & до & после & уменьшение \\
установки & установки & показателя $S A I F I$, & установки & установки & показателя $S A I D I$, \\
реклоузера & реклоузера & раз & реклоузера & реклоузера & раз \\
\hline 115,7 & 7,67 & $\approx 15$ & 694,2 & 26,3 & $\approx 26$ \\
\hline
\end{tabular}

Выводы. Применение в сельских распределительных сетях 6-35 кВ интеллектуальных секционирующих устройств - реклоузеров направлено на обеспечение децентрализованной автоматизации и управляемости сети, повышение надежности и качества энергоснабжения без проведения традиционной реконструкции фидеров. Секционирующие устройства - реклоузеры целесообразно использовать в сети для организации АВР и АПВ, защиты минимального напряжения, максимальной токовой защиты, защиты от однофазных замыканий на землю, подключения новых потребителей. Оценка уровня надежности и качества электроснабжения распределительной сети осуществляется по индикативным показателям SAIFI и SAIDI, характеризующим соответственно количество и длительность отключений в сети за рассматриваемый период.

\section{Библиографический список}

1. О единой технической политике в электросетевом комплексе [Текст]: Положение ПАО «Россети», утв. Советом директоров ПАО «Россети». Протокол от 22.02.2017 № 252. Москва, 2017. $196 \mathrm{c}$.

2. Об утверждении методических указаний по расчету уровня надежности и качества поставляемых товаров и оказываемых услуг для организации по управлению единой национальной (общероссийской) электрической сетью и территориальных сетевых организаций [Электронный ресурс] / Приказ Министерства энергетики РФ от 29 ноября 2016 г. № 1256. Режим доступа: http://www.garant.ru/products/ipo/prime/doc/ 71478114/, дата обращения 10.12.2018.

3. О внесении изменений в методические указания по расчету уровня надежности и качества поставляемых товаров и оказываемых услуг для организации по управлению единой национальной (общероссийской) электрической сетью и территориальных сетевых организаций, утвержденные приказом Минэнерго России от 29 ноября 2016 г. № 1256 [Электронный ресурс]: приказ Министерства энергетики РФ от 21.06. 2017 г. № 544. Режим доступа: http://www.garant. ru/products/ipo/prime/doc/71625358/, дата обращения 10.12.2018.

4. Правила устройства электроустановок [Электронный ресурс] / ПУЭ, шестое и седьмое издания (все действующие разделы). Режим доступа: https://docplan.ru/Data2/1/4294853/429485 3915.pdf, дата обращения 10.12.2018.

5. Линейное коммутационное оборудование 6-35 кВ - секционирующие пункты (рекло- узеры) [Текст]. Том 1.1 Общие данные: СТО 34.01-2.2-032-2017, введ. 14.11.2017 // Сборник типовых технических решений ПАО «Россети», 2017. $24 \mathrm{c}$.

6. Линейное коммутационное оборудование 6-35 кВ - секционирующие пункты (реклоузеры). Том 1.2 Секционирующие пункты (реклоузеры) [Текст] // Сборник типовых технических решений ПАО «Россети». Книга 1.2.1 Реклоузеры АО «ГК «Таврида Электрик». Книга 1.2.2 Секционирующие пункты $3 \mathrm{AO}$ «ГК «Электрощит» ТМ Самара»: СТО 34.01-2.2-033-2017. Россети, 2017. 24 с.

7. Реклоузеры 6-35 кВ. Общие технические требования: СТО 34.01-3.2-004-2016 [Текст] // Сборник типовых технических решений. Россети, 2016. 24 c.

8. Information and Computer Complex for Identification of Single-Phase Earth Faults in Electric Networks of 6-10 kV. Lyudmila P. Andrianova, Eduard R. Bayburin, Ildar I. Gabitov et al. J. of Engineering and Applied Sciences. 2018. Volume 13. Issue: 9 SI. Page 7141-7149.

9. 6-10 kV Overhead Pover Lines Effiency Researchh under the Influence of Wind and lce Loads. Vladimir Yu. Kabashov, Lyudmila P. Andrianova, Ildar I. Gabitov et al. J. of Engineering and Applied Sciences. 2018. Volume 13. Issue 10 SI. Page No. 8346-8352.

10. Андрианова, Л.П. Оценка уровня надежности в сельской распределительной сети с интеллектуальными реклоузерами по индикативным показателям SAIFI и SAIDI [Текст] / Л.П. Андрианова, В.Ю. Кабашов, Д.С. Хай- 
рисламов // Тенденции развития науки и образования. Декабрь 2018. № 45. Часть 8. Самара: Л-Журнал, 2018. С. 13-19.

11. Васильева, Т.Н. Выбор оптимального места расположения секционирующего реклоузера на радиальных линиях электропередач [Текст] / Т.Н. Васильева // Научное сопровождение инновационного развития агропромышленного комплекса: теория, практика, перспективы: материалы 65-й Межд. науч.-практ. конф. 20 21 мая 2014 г. Рязань: Рязанский государственный агротехнологический факультет, 2014. Ч. 2. $237 \mathrm{c}$.

12. Воротницкий, В.Э. Надежность распределительных электрических сетей 6(10) кВ - автоматизация с применением реклоузеров [Текст] / В.Э. Воротницкий, В.В. Воротницкий // Новости электротехники. 2002. № 5. С. 22-25.

13. Гришин, Д.А. Экономическая эффективность применения вакуумных реклоузеров серии PBA/TEL [Текст] / Д.А. Гришин, T.M. Василькова // Труды Костромской государственной сельскохозяйственной академии. Караваево: Костромская ГСХА, 2016. С. 141-147.

14. Долецкая, Л.И. Оценка эффективности методов повышения надежности распределительных электрических сетей [Электронный ресурс] / Л.И. Долецкая, В.П. Кавченков, Р.В. Солопов // Науковедение. Том 7, № 6 (2015). Режим доступа: https://naukovedenie.ru|PDF|98TVN615. pdf (доступ свободный). Загр. с экрана.

15. Куценко, Г.Ф. Повышение надежности электроснабжения потребителей АПК при использовании пунктов автоматического резервирования [Электронный ресурс] / Г.Ф. Куценко, А.Г. Ус, А.А. Парфенов // Вестник Гомельского государственного технического университета им. П.О. Сухого. Режим доступа: https://cyber leninka.ru/article/v/povyshenie-nadezhnosti-elektro snabzheniya-potrebiteley-apk, дата обращения 01 . 02.2019.

16. Куценко, Г.Ф. Расчет количества отключений потребителя АПК при наличии пунктов автоматического секционирования [Электронный ресурс] / Г.Ф. Куценко О.Ю. Пухальская, О.С. Шведова // Вестник Гомельского государственного технического университета им. П.О. Сухого. Режим доступа: https://cyberleninka. $\mathrm{ru} /$ article/v/raschet-kolichestva-otklyucheniy-potre bitelya-apk-pri-nalichii-punktov-avtomaticheskogo -sektsionirovaniya, дата обращения 01.02.2019.

17. Сазыкин, В.Г. Критерии оптимизации места установки реклоузера в распределительной сети 6-10 кВ [Текст] / В.Г. Сазыкин, А.Г. Кудряков, А.А. Багметов // Электротехнические системы и комплексы. 2018. № 1 (38). C. 33-39.

\section{Сведения об авторах}

1. Андрианова Людмила Прокопьевна, доктор технических наук, профессор кафедры электроснабжения и применения электрической энергии в сельском хозяйстве, ФГБОУ ВО Башкирский ГАУ, г. Уфа, ул. 50-летия Октября, 34, e-mail: alp3003@yandex.ru.

2. Кабашов Владимир Юрвевич, доктор технических наук, доцент кафедры безопасности и жизнедеятельности, ФГБОУ ВО Башкирский ГАУ, г. Уфа, ул. 50-летия Октября, 34, e-mail: kabashov@bk.ru.

3. Хайрисламов Данил Сулейманович, аспирант кафедры электроснабжения и применения электрической энергии в сельском хозяйстве, ФГБОУ ВО Башкирский ГАУ, г. Уфа, ул. 50-летия Октября, 34, e-mail: hairislamow2014@yandex.ru.

Изложены принципы повышения уровня надежности сельских распределительных сетей 6-35 кВ на базе интеллектуальных коммутационных аппаратов - реклоузеров со специализированными интегрированными контроллерами. Показаны типовые места установки реклоузера для радиального и кольцевого фидеров при подключении нового потребителя и разграничения балансовой принадлежности, а также при выделении ответственного потребителя с указанием особенностей схем подключения. Обоснован выбор оптимального количества реклоузеров для радиального и кольцевого фидера по инди- кативным показателям RNRE и ARAE, характеризующим соответственно относительную эффективность реконструкции сети за счет уменьшения количества отключений потребителей в год и среднюю эффективность инвестиций в реконструкцию сети при установке реклоузеров. Приведена методика определения индикативных показателей надежности SAIFI и SAIDI, характеризующих в электрической сети соответственно среднее годовое количество отключений потребителей и среднюю годовую продолжительность одного отключения. 


\title{
SAIFI AND SAIDI INDICATIVE RELIABILITY FIGURES OF RURAL ELECTRIC NETWORKS WITH SMART ISLAND RECLOSERS
}

Key words: rural electric networks; reliability of power supply; ring feeder; islanding; smart reclosers; indicative figures.

\section{Authors' personal details}

1. Andrianova Lyudmila, Doctor of technical sciences, professor of the department of Power Supply and Use of Electric Energy in Agriculture, Federal State Budgetary Educational Institution of Higher Education «Bashkir State Agrarian University», Ufa, 50-letiia Octiabria St., 34, e-mail: alp3003@yandex.ru.

2. Kabashov Vladimir, Doctor of technical sciences, associate professor of the department of Life and Processing Equipment Safety, Federal State Budgetary Educational Institution of Higher Education «Bashkir State Agrarian University», Ufa, 50-letiia Octiabria St., 34, e-mail: kabashov@bk.ru.

3. Khairislamov Danil, Post-graduate student of the department of Power Supply and Use of Electric Energy in Agriculture, Federal State Budgetary Educational Institution of Higher Education «Bashkir State Agrarian University», Ufa, 50-letiia Octiabria St., 34, e-mail: hairislamow2014@yandex.ru.

The paper describes principles of improving the reliability of rural distribution networks of $6-35 \mathrm{kV}$ based on smart switching devices, reclosers with specialized integrated controllers. The typical places to install reclosers for the radial and ring feeders are shown. They are mounted when a new consumer is connected and balance membership is delimited. It is also done to identify a responsible consumer with an indicated connection diagrams. The choice of the optimal number of reclosers for the radial and ring feeders according to indicative

(C) Андрианова Л.П., Кабашов В.Ю., Хайрисламов Д.С. figures RNRE and ARAE, characterizing the relative efficiency of network reconstruction by reducing the number of consumer outages per year, and the average investment efficiency in network reconstruction when installing reclosers, is justified. There is presented a method to find SAIFI and SAIDI indicative reliability figures that characterize the average annual number of customer disconnections and the average annual duration of one disconnection in the electrical network.

УДК 631.363

DOI: $10.31563 / 1684-7628-2019-51-3-92-99$

М.В. Борисова, А.Ю. Титов, В.В. Новиков, В.В. Коновалов

ВЛИЯНИЕ КОЛИЧЕСТВА ВОЗДЕЙСТВИЙ

ЛОПАСТЕЙ ТИХОХОДНОГО СМЕСИТЕЛЯ

НА КАЧЕСТВО ПРИГОТАВЛИВАЕМОЙ СМЕСИ

\begin{abstract}
Ключевые слова: смеситель; смешивание; качество смеси; частота вращения; лопасть; винтообразная форма; количество воздействий.
\end{abstract}

Введение. Для нормального функционирования организма животных и обеспечения их необходимой энергией очень важно вносить в корма зерновые культуры. Из-за низкого качества и недостаточного количества комбикормов генетический потенциал животных реализуется лишь наполовину. Другой важной задачей является снижение энергозатрат на приготовление смеси [1]. Приготовление кормовых смесей осу- ществляется смесителями разнообразной конструкции, а также шнековыми устройствами и экструдерами $[5,6]$. Большее распространение получили горизонтальные смесители с рабочим органом в виде лопастной мешалки, установленной на валу. Конструкция подобных мешалок не всегда удачна, вследствие чего ими потребляется существенное количество энергии. Поэтому совершенствование конструкции лопаст- 
ного смесителя является важной народнохозяйственной задачей. В этом отношении тихоходные смесители являются более экономичными. Однако возникает вопрос определения необходимого количества воздействий лопастей тихоходных смесителей на качество приготавливаемой смеси. К сожалению, работ, посвященных данному вопросу, мало и они не в полной мере раскрывают существующие зависимости $[3,4,7$, $9,10]$. В соответствии с нормативами и зоотехническими требованиями к кормам используемые механические средства должны обеспечивать приготовление кормосмесей с надлежащим качеством, соблюдением нормы выдачи и величины допустимых отклонений от нормы, минимальной энергоемкостью проведения процессов.

Цель исследований - установление выражений, описывающих неравномерность смешивания в зависимости от количества воздействий, приходящихся на единицу массы смеси, а также массы смеси, приходящейся на воздействие лопасти мешалки тихоходного смесителя.

Задачи исследований: 1) установить зависимости неравномерности смешивания в виде функции от массы смеси, приходящейся на воздействие лопасти мешалки тихоходного смесителя; 2) определить зависимости неравномерности смешивания в виде функции от количества воздействий, приходящихся на единицу массы смеси; 3) определить рациональные значения исследуемых факторов.

Условия, материалы и методы исследований. На основании обзора литературы и анализа технологического процесса смешивания зерновой смеси в Самарской ГСХА разработана конструкция смесительного агрегата непрерывного действия сыпучих материалов (рисунок 1) [2, 8]. Смесительная камера предлагаемого агрегата показана на рисунке 1. Методика исследований соответствует СТО АИСТ 19.2-2008 и предусматривает экспериментальное определение числовых значений неравномерности смешивания (как коэффициент вариации содержания контрольного компонента в пробах). В качестве показателя неравномерности смеси в таблице 1 использовалось среднее арифметическое значение коэффициентов вариации по трем повторностям. При определении качества смеси контрольным компонентом использовались зерна ячменя с долей $1 \%$ от массы смеси. Количество взятых проб - 15 шт. с массой пробы $100 \pm 5$ г. Длительность смешивания компонентов смеси составляла 6 мин. Обработка данных результатов исследований с целью получения регрессионных моделей осуществлялась компьютерной программой Statistica 5.5 .

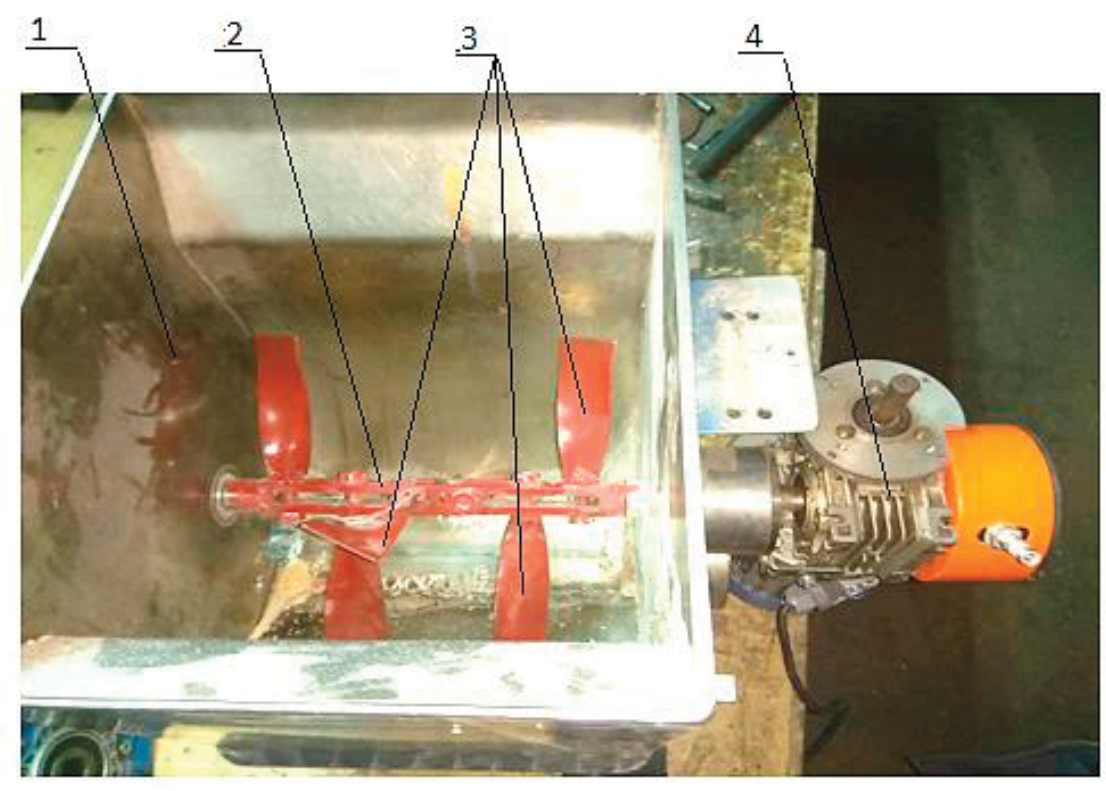

Рисунок 1

Общий вид смесительной камеры:

1 - смесительная камера; 2 - вал; 3 - винтообразные лопасти; 4 - электродвигатель

Результаты исследований. В результате проведения экспериментов по исследованию влияния на неравномерность смеси количества воздействий лопастей на единицу массы приготавливаемой порции смеси в соответствии с пла- ном Бокса - Бенкина для трех факторов (таблица 1) установлено влияние массы кормовой порции M (кг), количества воздействий мешалки за время смешивания К (шт.), количества воздействий мешалки за время смешивания в расчете 
на единицу массы смеси К’М (шт./кг), массы кормовой порции, приходящейся на одно воздействие лопасти мешалки МК' (кг/шт.). Масса приготавливаемой смеси определялась взвешиванием, а степень заполнения емкости смесителя определялась из выражения массы смеси M, кг:

$$
\mathrm{M}=\mathrm{V} \cdot \varepsilon \cdot \rho,
$$

где V - объем смесителя, $0,001 \mathrm{~m}^{3} ; \varepsilon$ - степень заполнения, 0,01\%; $\rho$ - плотность смеси, т/м³.

Количество воздействий лопастей за смешение порции смеси, шт.:

$$
\mathrm{K}^{\mathrm{N}}=\mathrm{n} \cdot \mathrm{Z} \cdot \mathrm{T} \text {, }
$$

где $\mathrm{n}$ - частота вращения, мин ${ }^{-1} ; \mathrm{Z}$ - количество лопастей, шт.; Т - средняя длительность смешивания, сек.
Количество воздействий лопастей на единицу массы, шт./кг [13]:

$$
\mathrm{K}^{\prime} \mathrm{M}=\frac{(\mathrm{n} \cdot \mathrm{Z} \cdot \mathrm{T})}{(\mathrm{V} \cdot \varepsilon \cdot \rho)} .
$$

Масса смеси, приходящаяся на воздействие лопасти, кг/шт.:

$$
\mathrm{MK}^{\prime}=\frac{(\mathrm{V} \cdot \varepsilon \cdot \rho)}{(\mathrm{n} \cdot \mathrm{Z} \cdot \mathrm{T})} .
$$

Наибольший коэффициент парной корреляции между указанными показателями и неравномерностью смешивания $v(\%)-$ у показателя $\mathrm{MK}^{\prime}$, равный $\mathrm{R}=0,925581$, затем у $\mathrm{K}^{`} \mathrm{M}$, равный $\mathrm{R}=-0,9$. Значения для $\mathrm{K}^{\prime}$ и $\mathrm{M}$ были менее 0,85 , что не свидетельствует о хорошей корреляции показателей. Анализ графиков на рисунке 2 показывает отсутствие корреляции между массой и количеством воздействий лопастей между собой.

Таблица 1 Результаты реализации плана Бокса - Бенкина для трех факторов по определению неравномерности смеси и соответствующее количество воздействий лопастей

\begin{tabular}{|c|c|c|c|c|}
\hline $\mathrm{MK}^{\prime}$ & $\mathrm{K}^{\prime} \mathrm{M}$ & $\mathrm{K}^{\prime}$ & $\mathrm{M}$ & $v$ \\
\hline 0,006667 & 150,0 & 1080 & 7,2 & 27,7 \\
\hline 0,004444 & 225,0 & 1080 & 4,8 & 25,5 \\
\hline 0,002222 & 450,0 & 1080 & 4,4 & 21,6 \\
\hline 0,006667 & 150,0 & 720 & 4,8 & 28,4 \\
\hline 0,003333 & 300,0 & 1440 & 7,2 & 23,4 \\
\hline 0,00375 & 266,7 & 1920 & 2,4 & 2,8 \\
\hline 0,00125 & 800,0 & 1920 & 2,4 & 22,7 \\
\hline 0,0025 & 400,0 & 960 & 7,2 & 28,9 \\
\hline 0,0075 & 133,3 & 960 & 4,8 & 23,6 \\
\hline 0,003333 & 300,0 & 1440 & 4,8 & 28,1 \\
\hline 0,006667 & 150,0 & 720 & 7,2 & 28,3 \\
\hline 0,0075 & 133,3 & 960 & 7,2 & 33,2 \\
\hline 0,015 & 66,7 & 480 & 2,4 & 22,2 \\
\hline 0,0025 & 400,0 & 960 & 2,4 & 27,2 \\
\hline 0,005 & 200,0 & 480 & $\mathrm{R}$ & - \\
\hline $\mathrm{R}$ & $-0,9$ & $\mathrm{R}$ & 0,669922 & - \\
\hline 0,925581 & & $-0,71985$ & & \\
\hline
\end{tabular}

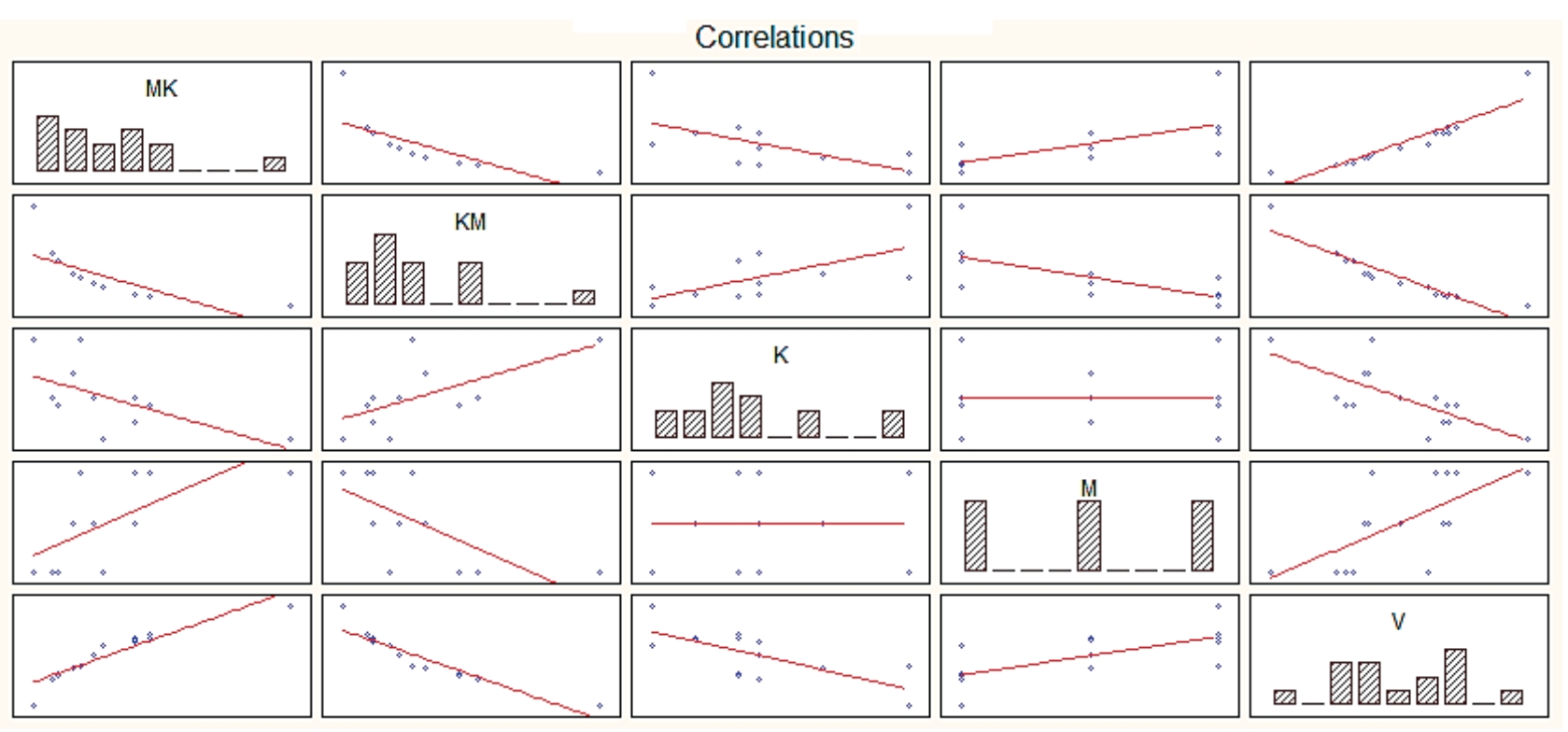

Рисунок 2

График корреляции факторов между собой и неравномерностью смеси $v$ 

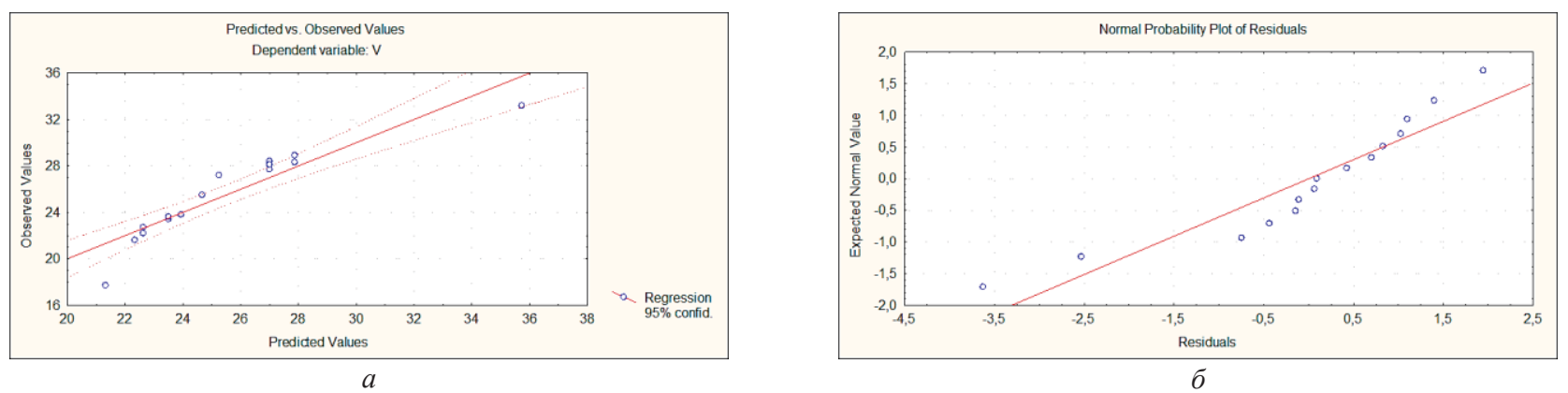

Рисунок 3

Результаты проверки сходимости расчетных и экспериментальных значений на нормальной бумаге: $a$ - распределение значений неравномерности; $\sigma$ - распределение неучтенных отклонений

Показатели К'М и МК' являются производными от данных факторов, что видно из формул (3), (4), а также отражено на рисунке 2. Если для М и К с одной стороны и с другой $-v$ имеется определенный разброс значений (правый столбик рисунка 2), то для К'М и МК' экспериментальные значения четко располагаются по некой кривой. Установим влияние массы смеси, приходящейся на одно воздействие, на неравномерность смеси $v(\%)$ в виде линейной функции. Данная зависимость опишется функцией

$$
v=20,01576+1047,621 \cdot\left(\mathrm{M} / \mathrm{K}^{\prime}\right) \text {. }
$$

Множественный коэффициент корреляции составляет $\mathrm{R}=0,92558127$, доверительная вероятность результата по F-тест менее 0,9 и графический анализ соответствия значений (рисунок 3) свидетельствуют о неадекватности модели.

Неравномерность смеси достаточно хорошо описывается показательной либо гиперболической (как частный случай степенной зависимости с отрицательным значением степени) функциями $[11,12]$. Для описания неравномерности смешивания используем степенную зависимость (рисунок 4):

$$
\begin{gathered}
v=-192,286+ \\
+253,6435 \cdot\left(\mathrm{M} / \mathrm{K}^{\prime}\right)^{0,028089} .
\end{gathered}
$$

Коэффициент корреляции $\mathrm{R}=0,99369$, F-тест $=0,98141$ и графический анализ соответствия значений (рисунки 5, 6) свидетельствуют об адекватности модели. Увеличение массы смеси, приходящейся на воздействие лопасти, повышает неравномерность смеси, что ухудшает качество корма. Уменьшение указанной массы резко улучшает качество смеси. Поэтому перспективна степень заполнения емкости непрерывных смесителей $20 . .25 \%$. Однако это снижает производительность периодического смесителя.

Установим влияние количества воздействий, приходящихся на единицу массы порции, на неравномерность смеси $v(\%)$ в виде линейной функции. Данная зависимость опишется функцией:

$$
v=30,78511-0,11562 \cdot\left(K^{\prime} / M\right) .
$$

Множественный коэффициент корреляции составляет $\mathrm{R}=0,92471523$, доверительная вероятность результата по F-тест менее 0,9 и графический анализ соответствия значений (рисунок 7) свидетельствуют о неадекватности модели.

Для описания неравномерности смешивания используем степенную [14] зависимость (рисунок 8):

$$
\begin{gathered}
v=-196,324+ \\
+257,6336 \cdot\left(K^{\prime} / M\right)^{-0,02758} .
\end{gathered}
$$

Коэффициент корреляции $\mathrm{R}=0,99369$, F-тест $=0,98138$ и графический анализ соответствия значений (рисунки 9, 10) свидетельствуют об адекватности модели.

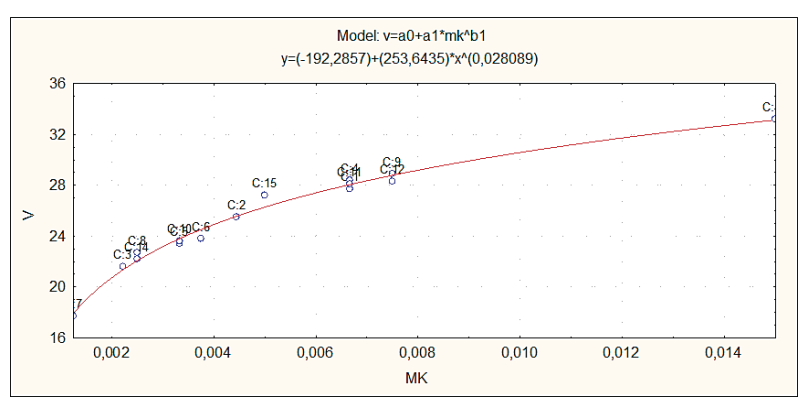

Рисунок 4

Влияние массы материала смеси МК (кг/шт.), приходящейся на воздействие лопасти, на неравномерность смеси $v(\%)$ 

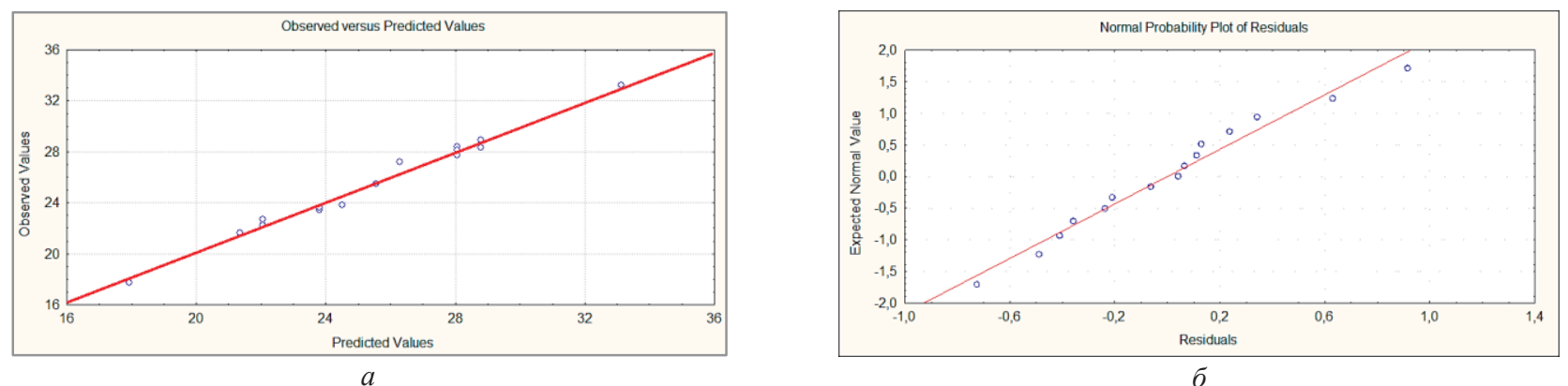

Рисунок 5

Результаты проверки сходимости расчетных и экспериментальных значений на нормальной бумаге: $a$ - распределение значений неравномерности; $\sigma$ - распределение неучтенных отклонений

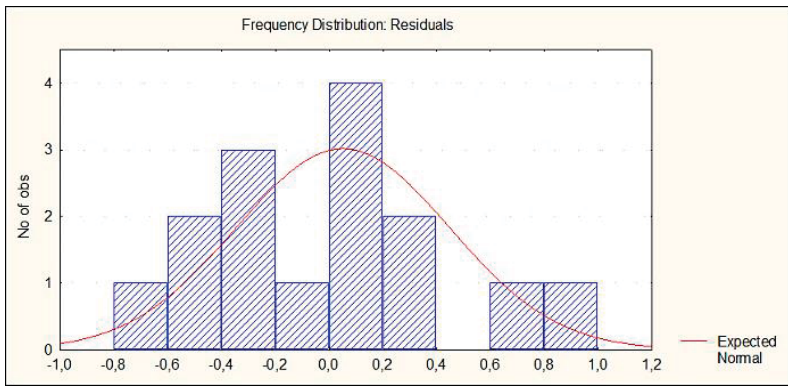

Рисунок 6

Результаты проверки неучтенных остатков на соответствие нормальному закону

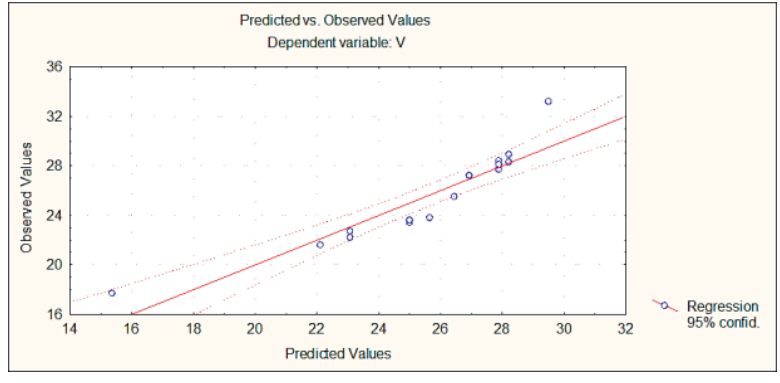

$a$

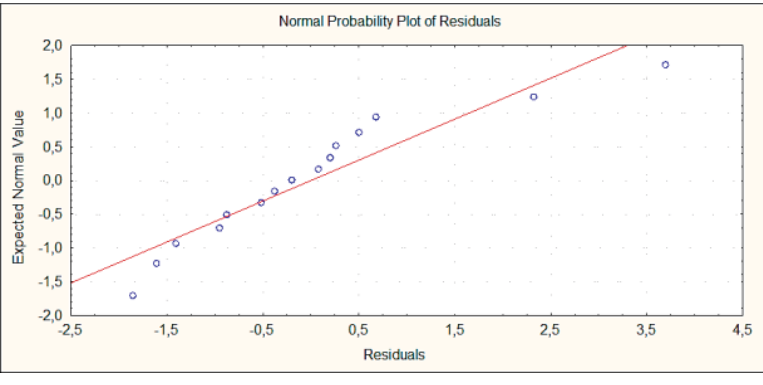

6

Рисунок 7

Результаты проверки сходимости расчетных и экспериментальных значений на нормальной бумаге: $a$ - распределение значений неравномерности; $\sigma$ - распределение неучтенных отклонений

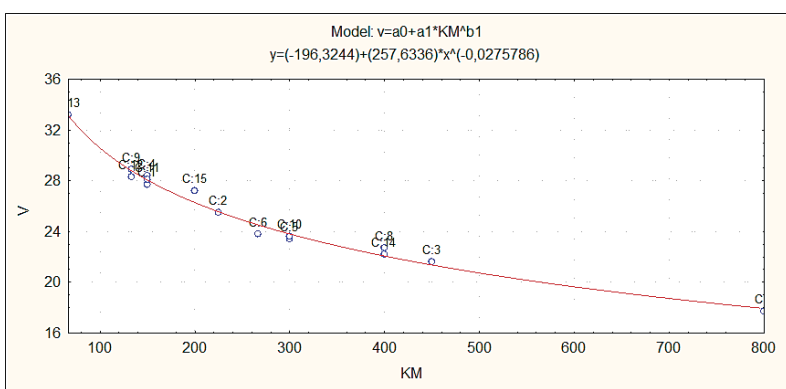

Рисунок 8

Влияние количества воздействий КМ (шт./кг), приходящихся на килограмм приготовленной смеси, на неравномерность смеси $v(\%)$

Увеличение количества воздействий, приходящихся на единицу массы смеси, уменьшает неравномерность смеси $v(\%)$, повышая ее качество. При этом характер изменения неравномерности соответствует гиперболической зависи- мости как одному из частных случаев степенной функции. По мере уменьшения неравномерности смеси резко увеличивается прирост количества воздействий. Сокращение длительности смешивания или массы приготавливаемой 
смеси снижает производительность смесителя, что ухудшает его работу. Учитывая, что количество воздействий определяется в первую оче-

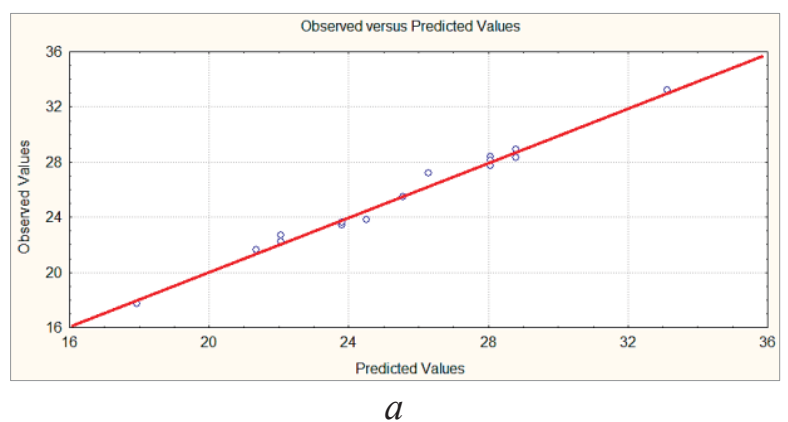

редь частотой вращения мешалки, для улучшения качества приготавливаемой смеси потребуется увеличить ее значения.

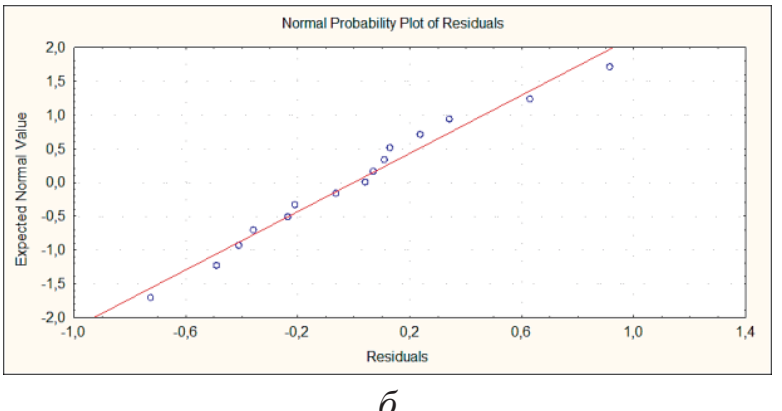

Рисунок 9

Результаты проверки сходимости расчетных и экспериментальных значений на нормальной бумаге: $a$ - распределение значений неравномерности; $\sigma$ - распределение неучтенных отклонений

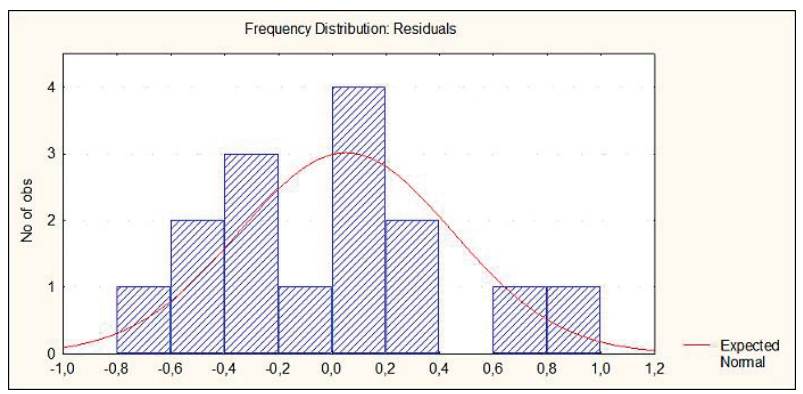

Рисунок 10

Результаты проверки неучтенных остатков на соответствие нормальному закону

Выводы. Проведенные экспериментальные исследования позволили установить выражения, описывающие неравномерность смешивания в зависимости от количества воздействий, приходящихся на единицу массы смеси, а также массы смеси, приходящейся на воздействие лопасти мешалки тихоходного смесителя. Степенная функция адекватно описывает экспериментальные результаты с доверительной вероятностью 98 \%. На исследованных участках изменения независимых факторов рациональные значения количества воздействий, приходящихся на единицу массы смеси К'M, не менее
800 шт./кг, а также массы смеси, приходящейся на воздействие лопасти мешалки тихоходного смесителя МК, не более 0,001 кг/шт. При доле контрольного (меньшего) компонента 1 \% 30отехнические требования к качеству смеси не выполняются. Вследствие этого приготовление смеси на основе премикса с долей $1 \ldots 2 \%$ не обеспечивает соблюдение зоотехнических требований, а в силу того, что доля БВД от состава комбикормовой смеси составляет $10 . .20 \%$, потребуются дополнительные исследования для установления зоны работоспособности смесителя в зависимости от доли контрольного компонента.

\section{Библиографический список}

1. Сыроватка, В.И. Ресурсосбережение при производстве комбикормов в хозяйствах [Текст] / В.И. Сыроватка // Техника и оборудование для села. 2011. № 6. С. 22-26.

2. Новиков, В.В. Методологические основы и обоснование структурно-функциональной схемы зерновой смеси [Текст] / В.В. Новиков, М.В. Борисова // Эксплуатация автотракторной и сельскохозяйственной техники: опыт, проблемы, инновации, перспективы: сб. науч. трудов. Пенза, 2017. С. 82-88.
3. Коновалов, В.В. Оптимизация параметров барабанного смесителя [Текст] / В.В. Коновалов, Н.В. Дмитриев, А.В. Чупшев, В.П. Терюшков // Нива Поволжья. 2013. № 4 (29). С. 4147.

4. Коновалов, В.В. Аналитические аспекты гравитационного смешивания барабанных устройств [Текст] / В.В. Коновалов, Н.В. Дмитриев, В.П. Терюшков, А.В. Чупшев // Известия Самарской государственной сельскохозяйственной академии. 2016. № 2. С. 40-46. 
5. Мартынова, Д.А. Повышение эффективности процесса производства экструдированных кормовых продуктов за счет изменения конструктивных параметров шнека пресс-экструдера [Текст]: дис. ... канд. техн. наук: 05.20.01 / Д.А. Мартынова. Оренбург: Оренбургский государственный университет, 2017. 167 с.

6. Хольшев, Н.В. Совершенствование технологического процесса приготовления сухих рассыпных кормосмесей шнеколопастным смесителем [Текст]: дис. ... канд. техн. наук: 05.20.01 / Н.В. Хольшев. Тамбов: Тамбовский государственный технический университет, 2015. 209 c.

7. Борисова, М.В. Рациональное деформирование лопастей смесителя и его влияние на динамику процесса [Текст] / М.В. Борисова, В.В. Новиков, А.Ю. Титов // Инновационные достижения науки и техники АПК : сб. науч. трудов. Кинель, 2018. С. 376-379.

8. Пат. 179164 Российская Федерация. Смеситель зерновой смеси [Текст] / В.В. Новиков, М.В. Борисова, А.С. Грецов, Д.Н. Котов, В.В. Коновалов. № 2017136899; заявл. 19.10 . 2017; опубл. 03.05.2018. Бюл. № 13.

9. Петрова, С.С. Сравнительные исследования смесителя с круглыми и плоскими лопастями [Текст] / С.С. Петрова, В.П. Терюшков, А.В. Чупшев, М.В. Коновалова // Известия Са- марской государственной сельскохозяйственной академии. 2011. № 3. С. 121-124.

10. Коновалов, В.В. Аналитическое обоснование длительности цикла работы смесителя периодического действия [Текст] / В.В. Коновалов, М.В. Фомина, В.П. Терюшков, А.В. Чупшев // Известия Самарской государственной сельскохозяйственной академии. 2015. № 3. С. 10-15.

11. Chupshev A., Konovalov V., Fomina M. Optimization in work modeling of a mixer. IOP Conf. Series. J. of Physics: Conf. Series 2018. № 1084-012010.

12. Коновалов, В.В. Моделирование изменения качества смеси лопастного смесителя на основе технологических параметров [Текст] / Коновалов В.В., Чупшев А.В., Фомина М.В. // Инновационная техника и технология. 2016. № 3 (8). C. 57-66.

13. Коновалов, В.В. Определение потребного количества воздействия лопастей на смесь [Текст] / В.В. Коновалов, В.П. Терюшков, А.В. Чупшев // Научные труды ГНУ ВНИИМЖ Россельхозакадемии. 2009. Т. 20. № 3. С. 107115.

14. Коновалов, В.В. Обоснование технологических параметров смесителя комбикормов [Текст] / В.В. Коновалов, И.А. Боровиков, С.В. Гусев, В.П. Терюшков // Нива Поволжья. 2006. № 1 (1). C. 27-29.

\section{Сведения об авторах}

1. Борисова Марина Викторовна, аспирант кафедры сельскохозяйственных машин и механизации животноводства, ФГБОУ ВО Самарская ГСХА, 446442, Самарская область, п. г. т. Усть-Кинельский, ул. Учебная, 2, e-mail: morskay6363@mail.ru.

2. Титов Андрей Юрьевич, аспирант кафедры сельскохозяйственных машин и механизации животноводства, ФГБОУ ВО Самарская ГСХА, 446442, Самарская область, п. г. т. Усть-Кинельский, ул. Учебная, 2, e-mail: titova_iv@mail.ru.

3. Новиков Владимир Васильевич, кандидат технических наук, профессор кафедры сельскохозяйственных машин и механизации животноводства, ФГБОУ ВО Самарская ГСХА, 446442, Самарская область, п. г. т. Усть-Кинельский, ул. Учебная, 2, e-mail: morskay6363@mail.ru.

4. Коновалов Владимир Викторович, доктор технических наук, профессор кафедры технологии машиностроения, ФГБОУ ВО Пензенский ГТУ, 440039, Пенза, проезд Байдукова, ул. Гагарина, 1a/11, e-mail: konovalov-penza@rambler.ru.

Установлены выражения, описывающие неравномерность смешивания в зависимости от количества воздействий лопастей смесителя, приходящихся на единицу массы смеси, а также массы смеси, приходящейся на воздействие лопасти мешалки тихоходного смесителя. На основании обзора литературы и анализа технологического процесса смешивания в Самарской ГСХА разработана конструкция лопастного смесителя. Смеситель состоит из корпуса, в котором расположен горизонтальный вал смеси- теля с рабочими органами, выполненными в виде радиальных лопастей винтообразных формы. Получены выражения, позволяющие определить неравномерность смеси от количества воздействий лопастей смесителя, приходящихся на единицу массы смеси, а также от массы смеси, приходящейся на воздействие лопасти мешалки тихоходного смесителя. Степенная функция адекватно описывает экспериментальные результаты с доверительной вероятностью 98 \%. На исследованных участках измене- 
ния независимых факторов оптимальным значением количества воздействий, приходящихся на единицу массы смеси, является не менее
800 шт./кг, а также массы смеси, приходящейся на воздействие лопасти мешалки тихоходного смесителя, - не более 0,001 кг/шт.

M. Borisova, A. Titov, V. Novikov, V. Konovalov

\section{INFLUENCE OF A NUMBER OF IMPACTS OF LOW-SPEED MIXER BLADES ON CONCRETE QUALITY BEING PREPARED}

Key words: mixer; mixing; concrete quality; rotation frequency; blade; helical shape; the number of impacts.

\section{Authors' personal details}

1. Borisova Marina, Post-graduate student of the department of Agricultural machines and mechanization of livestock breeding, Samara State Agrocultural Academy, 446442, Samara region, Ust'-Kinelsky settlement, Uchebnaya st., 2, e-mail: morskay6363@mail.ru.

2. Titov Andrei, Post-graduate student of the department of Agricultural machines and mechanization of livestock breeding, Samara State Agrocultural Academy, 446442, Samara region, Ust'-Kinelsky settlement, Uchebnaya st., 2, e-mail: titova_iv@mail.ru.

3. Novikov Vladimir, Candidate of technical sciences, professor of the department of Agricultural machines and mechanization of livestock breeding, Samara State Agrocultural Academy, 446442, Samara region, Ust'-Kinelsky settlement, Uchebnaya st., 2, e-mail: morskay6363@mail.ru.

4. Konovalov Vladimir, Doctor of technical sciences, professor of the Engineering technology department, Penza State Technological University, 440039, Penza, Baydukov/Gagarin Road, 1A/11, e-mail: konovalov-penza@rambler.ru.

The paper presents purpose equations describing the uneven mixing depending on the number of the mixer blade impacts per unit of concrete weight as well as the weight of the mixture that have an impact on blades of the slow-speed mixer. Based on the literature review and analysis of the mixing process conducted in the Samara State Agricultural Academy, the design of the blade mixer was developed. The mixer consists of a body where there is a horizontal shaft with working bodies, made in the form of radial blades of helical shape. There are received equations that allow determining the con- crete uniformity depending on a number of the impacts of the mixer blades per unit of the concrete weight as well as on the concrete weight that act on the blades of the slow-speed mixer. The power function is adequately described by the experimental results of $98 \%$ confidence probability. In the studied areas of changes in independent factors rational values of the number of impacts per unit of the concrete weight is not less than $800 \mathrm{PCs} / \mathrm{kg}$, as well as the concrete weight having impact on the blade of the slow-speed mixer is not more than $0,001 \mathrm{~kg} / \mathrm{PC}$.

(C) Борисова М.В., Титов А.Ю., Новиков В.В., Коновалов В.В.

УДК 621.43

DOI: $10.31563 / 1684-7628-2019-51-3-99-106$

А.В. Неговора, Р.Ж. Магафуров, А.И. Низамутдинов

\section{ОБОСНОВАНИЕ ТЕМПЕРАТУРЫ РАБОЧЕЙ ЖИДКОСТИ ПРИ ИСПЫТАНИИ ДИЗЕЛЬНЫХ ИНЖЕКТОРОВ}

Ключевые слова: испытание форсунок; топливная аппаратура; характеристика впрыска; термостабилизация; испытательный стенд.

Введение. Известно, что температурный режим топливной аппаратуры, особенно электро-

гидроуправляемых форсунок (инжекторов) типа Common Rail, оказывает значительное влияние 
на показатели топливоподачи в целом вследствие изменения физических свойств рабочей жидкости $[1,2]$. Поэтому при испытании форсунок или ТНВД представляется логичным создавать температурный режим, максимально приближенный к реальным условиям эксплуатации, что требует поддержания температуры измерительного устройства стенда в определенных пределах. Не все современные стенды, предназначенные для испытания топливной аппаратуры, имеют встроенную систему контроля температуры и термостабилизации. Стоит отметить, что в нормативной и технической документации нет четкого обоснования оптимальной температуры испытуемого агрегата или рабочей жидкости при испытании, в результате чего специалисты по ремонту топливной аппаратуры не уделяют должного внимания данному контрольному параметру тест-плана. Все это ведет к нарушению работы системы подачи топлива и снижению технико-экономических показателей работы автотракторной техники [3].
Целью исследования являлось повышение качества ремонта топливной аппаратуры дизелей путем обоснования рациональных допусков к температуре агрегата или рабочей жидкости при его испытании.

Условия, материалы и методы исследования. Данные, полученные при испытании топливной аппаратуры на обычных регулировочных стендах, позволяют оценить только усредненную цикловую подачу топлива, что не раскрывает возможные нарушения как единичных характеристик впрыскивания, так и их стабильность в процессе работы $[4,5]$. В связи с этим для формирования исследовательской базы экспериментально полученных данных нами было разработано устройство для оценки характеристики впрыскивания [6, 7].

Устройство (рисунок 1) состоит из длинного трубопровода 9 заданной длины, программно логической интегральной схемы (ПЛИС) 11 и управляющего оборудования с гидродинамической системой 1 для создания высокого давления.

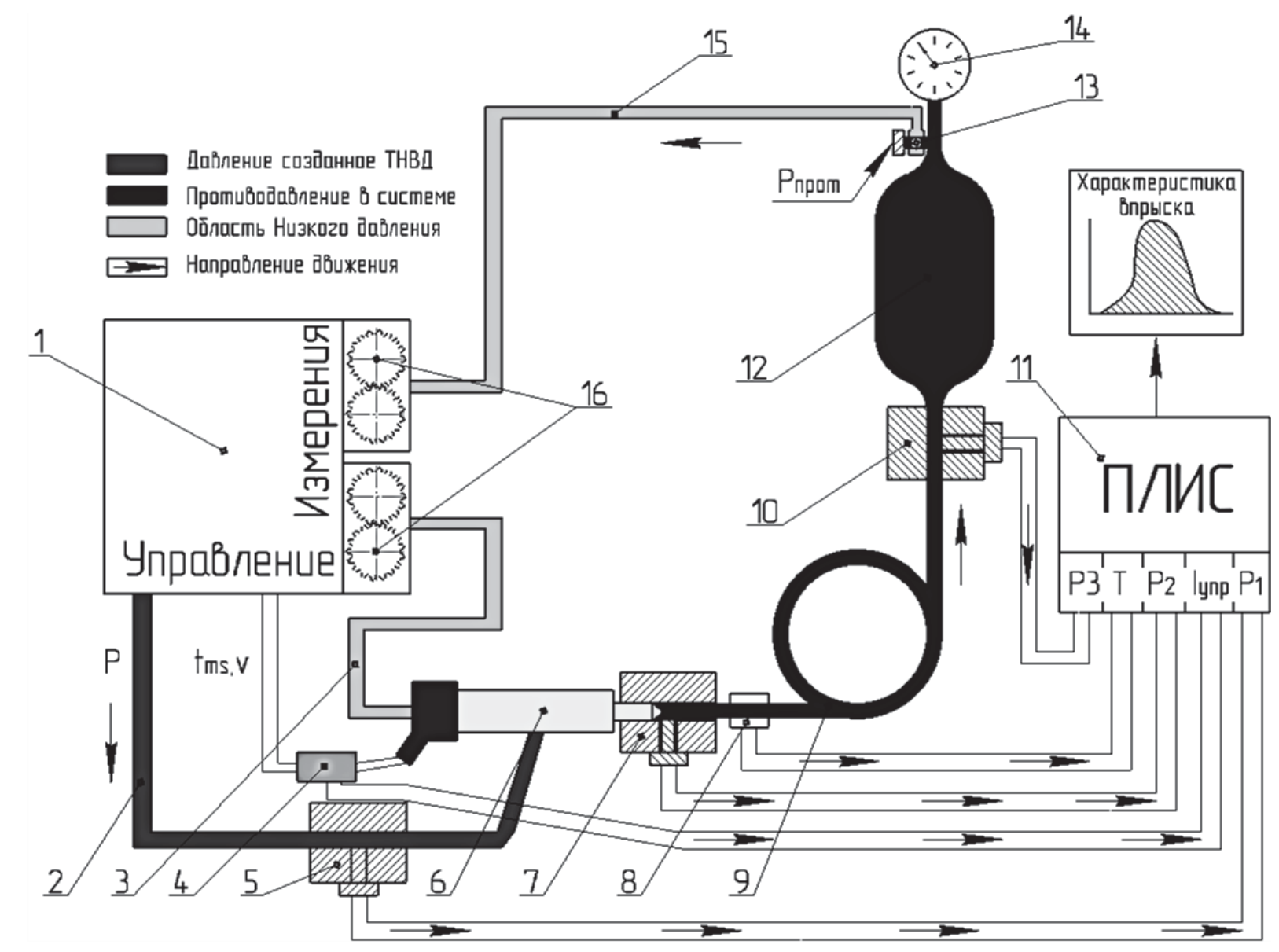

Рисунок 1

Принципиальная схема предлагаемого устройства: 1 - управляющее оборудование; 2 - топливопровод высокого давления; 3 - топливопровод обратного слива; 4 - датчик тока управляющего сигнала форсунки; 5 - датчик давления топлива в аккумуляторе; 6 - испытываемая форсунка; 7 - адаптер впрыска с датчиком давления; 8 - датчик температуры; 9 трубопровод; 10 - адаптер слива с датчиком давления; 11 - программно-логическая интегральная схема; 12 - ресивер; 13 - клапан противодавления впрыску топлива; 14 - манометр; 15 - трубопровод низкого давления; 16 - расходомеры 
Ресивер 12 служит для создания противодавления в трубопроводе 9 и позволяет снизить явление эффекта обратной волны. В начале и в конце трубопровода установлены два тензометрических датчика давления 7 и 10, которые связаны с ПЛИС для отображения изменения давления в определенных точках системы. Датчик давления топлива в аккумуляторе 5 необходим для определения изменения давления у штуцера инжектора в момент впрыска.
За основу разработанного устройства был принят метод оценки характеристик последовательных цикловых подач при впрыскивании топлива в длинный трубопровод [8]. Этот метод достаточно надежен, так как устройство не имеет подвижных и трущихся деталей, не содержит дорогостоящей прецизионной обработки, а главное - обеспечивает линейную зависимость влияния давления впрыскивания на расход топлива через сопла распылителя.

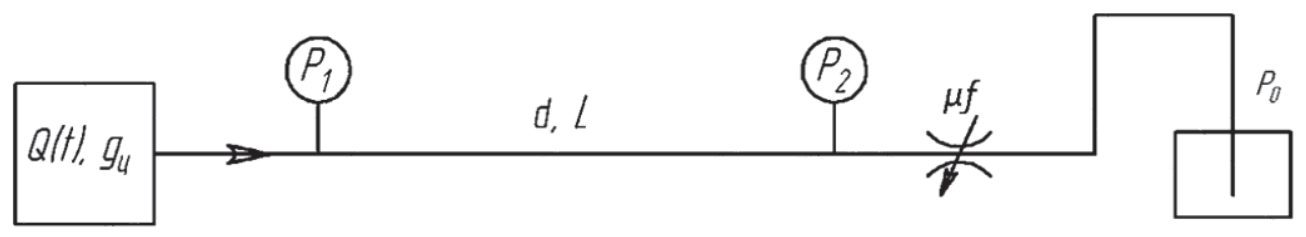

Рисунок 2

Схема устройства для оценки характеристик последовательных цикловых подач

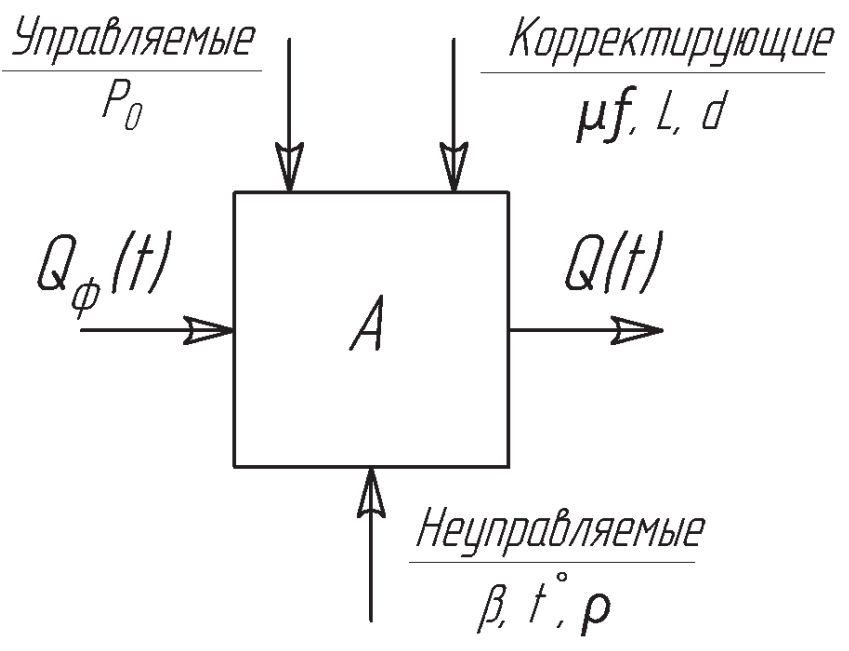

Рисунок 3

Информационная модель рабочего процесса устройства

Информационная модель рабочего процесса разработанного устройства представляется как многопараметрическая система (рисунок 3), где физические свойства рабочей жидкости (температура среды, плотность и сжимаемость жидкости и др.) являются неуправляемыми параметрами (Н). В качестве управляемых параметров $(\mathrm{У})$ определены величина цикловой подачи, частота и продолжительность впрыскивания. Корректировать рабочий процесс устройства можно путем изменения эффективного проходного сечения сливного клапана, длины и диаметра трубопровода, объема ресивера и др. (К).

Таким образом, можно утверждать, что итоговые показатели выходного вектора $\mathrm{Q}(\mathrm{t})$ определенным образом зависят от параметров всех входящих факторов

$$
\mathrm{Q}=\mathrm{F}\{\mathrm{H}, \mathrm{Y}, \mathrm{K}\},
$$

где $\mathrm{F}$ - заданный в аналитической форме оператор преобразования характеристик входящих факторов.

При этом, если зафиксированная и математически описанная устройством характеристика впрыскивания $\mathrm{Q}(\mathrm{t})$ соответствует фактической характеристике $\mathrm{Q}_{\phi}(\mathrm{t})$ в пределах погрешности $\Delta$, то можно считать, что устройство выдает действительную характеристику впрыскивания.

$$
\mathrm{Q}(\mathrm{t})=\mathrm{Q}_{\phi}(\mathrm{t}) \pm \Delta \text {. }
$$

Ниже представлен общий вид собранной экспериментальной установки (рисунок 4). Стабильное высокое давление, необходимое для надежной работы гидродинамической системы устройства, обеспечивалось стендом для испытания форсунок топливных систем типа Common Rail модели ВTC-101ME производства ООО «Башдизель» [9]. Стенд позволяет создать 
стабильное давление в аккумуляторе в диапазоне до 220 МПа независимо от режима работы форсунки, оценить гидроплотность ее прецизи- онных деталей (Leak test) и измерить производительность форсунки путём подачи соответствующих сигналов управления.

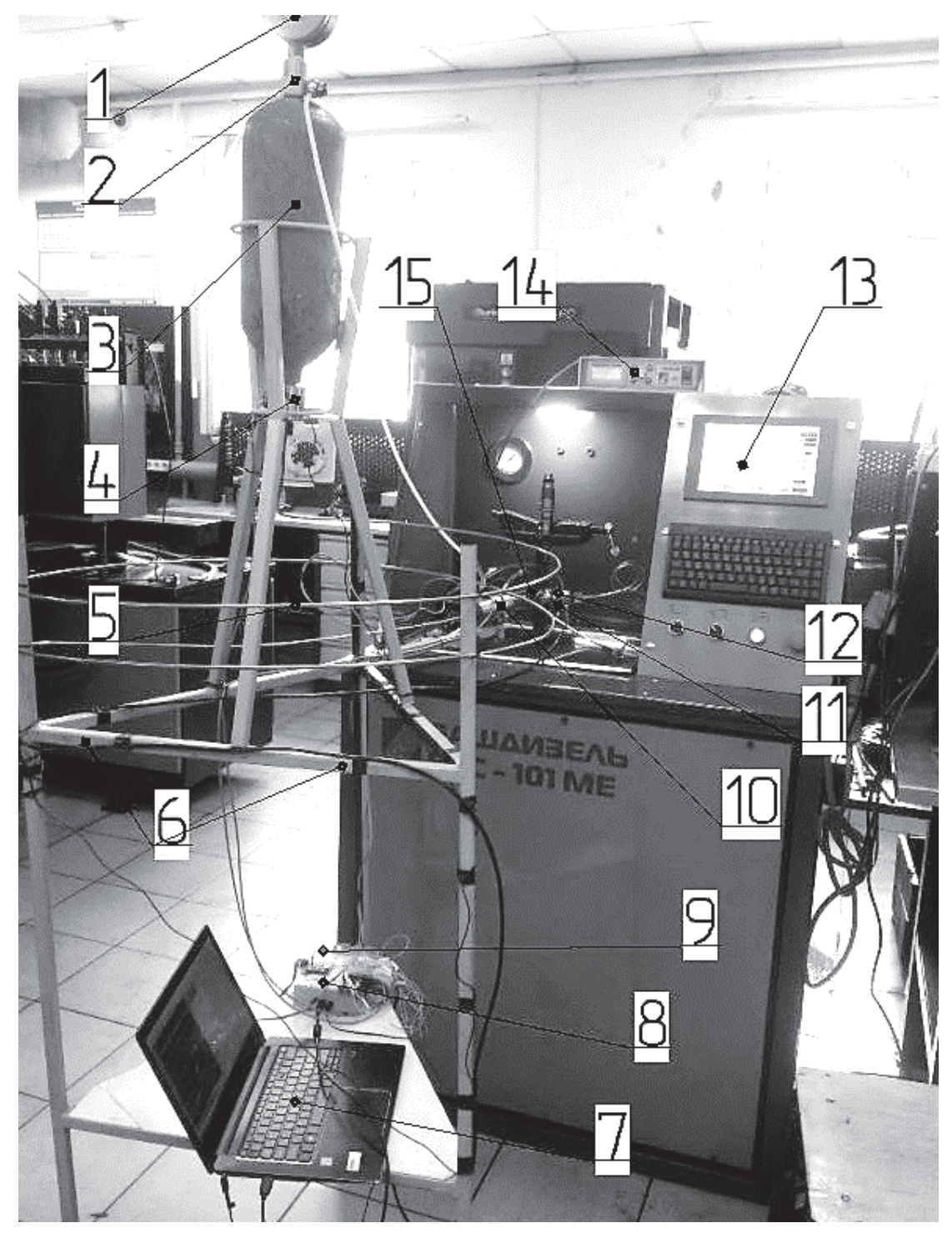

Рисунок 4

Общий вид устройства для оценки характеристики впрыска: 1 - манометр избыточного давления; 2 устройство противодавления впрыска топлива; 3 - ресивер; 4 - адаптер с тензометрическим датчиком давления; 5 - измерительный топливопровод; 6 - стойка; 7 - персональный компьютер; 8 - ПЛИС; 9 операционный усилитель; 10 - адаптер впрыска; 11 - форсунка; 12 - датчик давления перед форсункой; 13 - диагностический стенд ВТС-101ME; 14 - имитатор сигналов; 15 - датчик температуры

Перед началом испытания форсунки в меню управляющего оборудования устанавливается режим его работы, а именно: длительность управляющего сигнала форсунки $\mathrm{t}_{\mathrm{ms}}$, частота впрыскивания $v$, давление топлива в аккумуля-

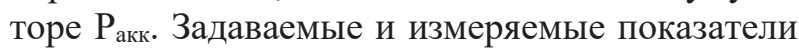
экспериментальной установки представлены в таблице 1.

Для поддержания заданной температуры тестируемой жидкости в ресивере установлен силиконо-керамический нагревательный элемент. Следует сказать, что таким нагревателям требу- ется мало времени для нагрева и снижения температуры, при этом они могут поддерживать необходимую температуру рабочей жидкости посредством ПЛИС с обратной связью по датчику температуры.

При испытаниях температура технологической жидкости фиксировалась датчиком температуры, установленным в адаптер впрыска в трубке, навитой по спиральной траектории. С целью повышения достоверности полученных показаний посадочное место температурного датчика заполнено теплопроводящей пастой. 
Предварительные испытания доказали работоспособность устройства. Установлено, что разработанное устройство позволяет достаточно точно зафиксировать характеристику и определить запаздывание начала впрыскивания от управляющего форсункой Common Rail сигнала и величину предварительного впрыскивания (рисунок 5). При проведении предварительных экспериментов для каждого значения частоты впрыскивания, давления топлива в аккумуляторе и длительности управляющего импульса определялась величина цикловой подачи и площадь под кривой давления с первого датчика. По этим значениям вычислялся коэффициент пропорциональности, значение которого существенно изменялась, что связано как раз с большими колебаниями температурного режима установки.

Таблица 1 Параметры экспериментальной установки

\begin{tabular}{|c|c|c|}
\hline \multicolumn{2}{|r|}{ Параметр } & Тип переменной \\
\hline $\begin{array}{c}\text { Особенности } \\
\text { рабочего процесса }\end{array}$ & $\begin{array}{ll}\text { - } & \text { Давление [MПа] } \\
\text { - } & \text { Противодавление [МПа] } \\
\text { - } & \text { Длительность сигнала [мс] } \\
\text { - } & \left.\text { Частота впрыскивания [мин }{ }^{-1}\right] \\
\end{array}$ & задаваемый \\
\hline Способы оценки & 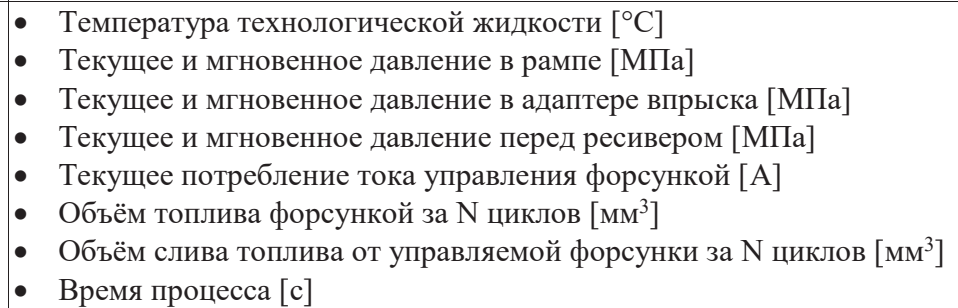 & измеряемый \\
\hline
\end{tabular}

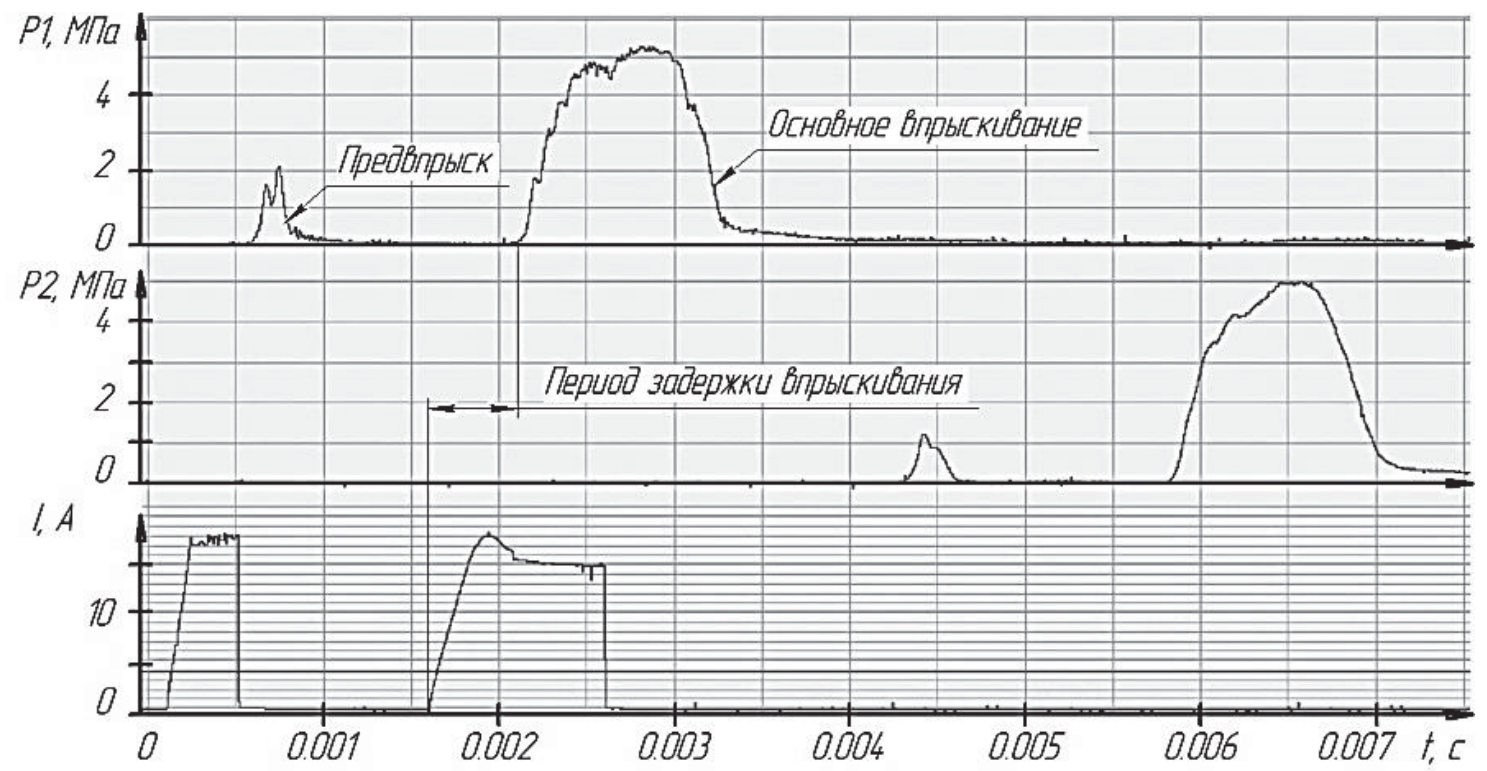

Рисунок 5

Характеристика основного и предварительного впрыскивания

Результаты исследований. Испытания проводились при величине цикловой подачи топлива, равной $30 \mathrm{mм}^{3} /$ ц, и противодавлении в системе, равном атмосферному давлению. Методика исследований по определению влияния температурного режима устройства на показатели работы форсунки подразумевает включение силиконо-керамического нагревательного элемента в циклическом режиме для равномерного нагрева устройства с шагом $5{ }^{\circ} \mathrm{C}$.
Исходя из конструктивных особенностей устройства и опираясь на данные других исследователей $[10,11,12]$, его нагрев ограничили температурой $70{ }^{\circ} \mathrm{C}$, так как чрезмерный нагрев тестовой жидкости и топливной аппаратуры оказывает положительный эффект только в узкой области на частичных нагрузках и при температуре до $100^{\circ} \mathrm{C}$. Там же указано, что влияние температуры топлива на процесс топливоподачи не сильно выражено при рабочих давлениях в 
линии нагнетания до 50 МПа, а это не актуально для современных топливоподающих систем. В случае, когда испытываются форсунки типа Common Rail, давление впрыскивания может достигать 250 МПа, поэтому пренебрегать термостабилизацией измерительного устройства недопустимо.

Полученные экспериментально данные позволили построить графические зависимости (рисунок 6) влияния температуры режима устройства на цикловую подачу топлива форсункой ди-

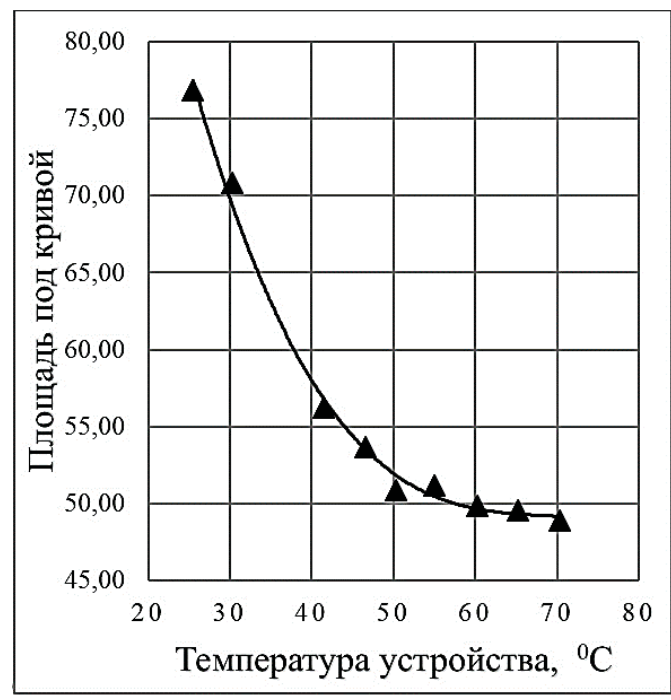

a) зеля. Анализ графиков показывает, что в диапазоне температур до $50{ }^{\circ} \mathrm{C}$ наблюдается существенное изменение площади под кривой давления, характеризующей цикловую подачу. При нагреве тестовой жидкости более $50{ }^{\circ} \mathrm{C}$ и площадь под кривой датчика давления, и скорость распространения волны давления стабилизируются. Подобный тренд имеют известные зависимости изменения сжимаемости топлива и его вязкости от температуры [13], что может быть взято за основу при исследовании подобного процесса.

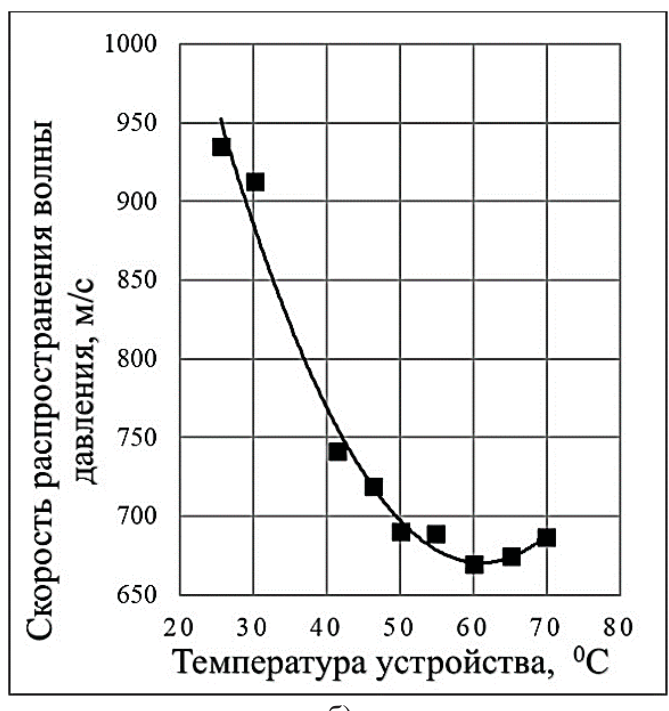

б)

Рисунок 6

Влияние температуры измерительного устройства на основные показатели датчика характеристики впрыскивания топлива: а) на площадь под кривой датчика давления; б) на скорость распространения волны давления

Вывод. Экспериментальные исследования подтвердили теоретические выводы о том, что с увеличением температуры тестовой жидкости и устройства скорость распространения волны давления в измерительном канале снижается. Это позволяет констатировать, что характер изменения в основном определяет вязкость дизельного топлива. Так при увеличении температуры с 25 до $50{ }^{\circ} \mathrm{C}$ скорость распространения волны давления снижается на 260 м/с и наблюдаются потери давления впрыскивания на 2,5 МПа. Минимальная скорость распространения волны давления зарегистрирована при тем- пературе устройства около $60^{\circ} \mathrm{C}$, в данной точке также происходит выравнивание температуры корпуса устройства и технологической жидкости. Данное значение температуры можно обоснованно принять в качестве оптимального температурного режима устройства.

Проведенные испытания позволили выявить, что для получения достоверных показателей при диагностировании топливной аппаратуры дизелей необходимо стабильно поддерживать рабочую температуру устройства в диапазоне $60 \pm 5{ }^{\circ} \mathrm{C}$.

\section{Библиографический список}

1. Грехов, Л.В. Топливная аппаратура и системы управления дизелей [Текст]: учебник для вузов / Л.В. Грехов, Н.А. Иващенко, В.А. Марков. М.: Легион-Автодата, 2004. С. 344.

2. Астахов, И.В. Топливные системы и экономичность дизелей [Текст] / И.В. Астахов, Л.Н. Голубков, В.И. Трусов, А.С. Хачиян. М.: Машиностроение, 1990. 288 с.
3. Габитов, И.И. Обеспечение работоспособности топливоподающих систем дизелей путем индивидуальной корректировки базовых характеристик управления топливоподачей [Текст] / И.И. Габитов, А.В. Неговора // Российская сельскохозяйственная наука. 2016. № 4. С. 84-88.

4. Ягодин, Р.В. Расширение функциональных возможностей стендов для испытания топ- 
ливной аппаратуры дизелей [Текст] / Р.В. Ягодин, А.Р. Валиев, А.А. Козеев // Труды ГОСНИТИ. 2008. Т. 102. С. 56-58.

5. Нигматуллин, Ш.Ф. Совершенствование методов и средств диагностирования топливной аппаратуры автотракторных и комбайновых дизелей [Текст]: дисс. ... канд. техн. наук / Ш.Ф. Нигматуллин. Уфа, 2002. 153 с.

6. Устройство для исследования подачи топлива топливоподающей аппаратурой в дизелях [Текст]: патент на изобретение № 2433299 / И.И. Габитов, А.В. Неговора, А.Г. Габбасов, А.Р. Валиев, А.Ф. Давлетов. Уфа: Башкирский ГАУ, НИЧ. Опубликовано 10.11.2011 г. Бюл. № 31 .

7. Неговора, А.В. Специализированное устройство для исследования закона подачи топлива в системах питания дизелей [Текст] / А.В. Неговора, А.И. Низамутдинов, Р.Т. Хакимов // Технико-технологические проблемы сервиса. 2014. № 3 (29). С. 11-13.

8. Patent № 1954938, F02 M65/00. Method and device for measuring the injection quantity and the injection rate of an injection valve for liquids. Robert Bosch GmbH, Stuttgart. Filed. 09.10.2006. Pub. 31.05.2007.
9. Козеев, А.А. Повышение эффективности диагностирования электрогидроуправляемых форсунок [Текст] / А.А. Козеев, Ш.Ф. Нигматуллин // Аграрный научный журнал. 2016. № 2. C. $50-54$.

10. Gabitov I.I., Insafuddinov S.Z., Akhmetov A.F., Kharisov D.D., Safin F.R. Diagnostics and regulation of fuel equipment of diesels on stands with injection to medium with counter-pressure. J. of Engineering and Applied Sciences. 2018. T. 13. № S11. C. 8782-8788.

11. Gabitov I.I., Saifullin R.N., Farhshatov M.N., Negovora A.V., Mudarisov S.G. Hardening of electrohydraulic injectors valve units of diesels at repair. J. of Engineering and Applied Sciences. 2018. T. 13. № S8. C. 6478-6486.

12. Olshevskiy S.N., Dobrolyubov I.P., Klimenko D.N., Orehov A.K., Borisov A.A. A new method of power system diagnostics for mobile equipment. International Siberian Conference on Control and Communications, SIBCON 2016. Proceedings 2016. Р. 749-802.

13. Файнлейб, Б.Н. Топливная аппаратура автотракторных дизелей [Текст] / Б.Н. Файнлейб. Л.: Машиностроение, 1990. С. 352.

\section{Сведения об авторах}

1. Неговора Андрей Владимирович, доктор технических наук, профессор кафедры автомобилей и машинно-тракторных комплексов, ФГБОУ ВО Башкирский ГАУ, г. Уфа, тел.: (347) 241-68-33, е-таil: negovora@bsau.ru.

2. Магафуров Руслан Жамилевич, старший преподаватель кафедры автомобилей и машиннотракторных комплексов, ФГБОУ ВО Башкирский ГАУ, г. Уфа, e-mail: magafuroffruslan@yandex.ru.

3. Низамутдинов Алмаз Ильдарович, инженер, г. Уфа, e-mail: almaz_nizamutdinov90@mail.ru.

В данной статье обоснованы допустимые пределы температуры рабочей жидкости при испытании топливной аппаратуры дизелей. В нормативной и технической документации не указана оптимальная температура рабочей жидкости при испытании. Результаты подтверждаются экспериментальными данными, полученными на разработанном авторами устройстве для оценки характеристики впрыскивания. За основу разработанного устройства был принят

A. Negovora, R. Magafurov, A. Nizamutdinov метод впрыскивания топлива в длинный трубопровод. Проведенные испытания позволили раскрыть влияние температуры топлива на показатели работы топливной аппаратуры дизелей и доказать, что для получения достоверных показателей при диагностировании топливной аппаратуры дизелей необходимо стабильно поддерживать рабочую температуру устройства в диапазоне $60 \pm 5^{\circ} \mathrm{C}$.

\section{SUBSTATIATION OF THE WORKING FLUID TEMPERATURE WHEN TESTING DIESEL INJECTORS}

Key words: test of injector nozzles; fuel equipment; characteristic of injection; thermal stabilization; test bench. 


\section{Authors' personal details}

1. Negovora Andrey, Doctor of Engineering Science, Professor, Department of the Cars and Tractor Systems, Federal State Budgetary Educational Institution of Higher Education «Bashkir State Agrarian University», Ufa, phone: (347) 241-68-33, e-mail: negovora@bsau.ru.

2. Magafurov Ruslan, senior lecturer, Department of Cars and Tractor Systems, Federal State Budgetary Educational Institution of Higher Education «Bashkir State Agrarian University», Ufa, Russia, e-mail: magafuroffruslan@yandex.ru.

3. Nizamutdinov Almaz, engineer, Ufa, Russia, e-mail: almaz_nizamutdinov90@mail.ru.

This paper substantiates the permissible temperature limits of the working fluid when testing diesel fuel equipment. The normative and technical documentation does not indicate the optimum temperature of the working fluid during the test. The results are confirmed by experimental data obtained on a device developed by the authors for evaluating the injection characteristics. The developed device was

(C) Неговора А.В., Магафуров Р.Ж., Низамутдинов А.И. based on the method of fuel injection into a long pipeline. The tests revealed the effect of fuel temperature on the performance of diesel fuel equipment. Also, the tests proved that in order to obtain reliable indicators when diagnosing diesel fuel equipment it is necessary to stably maintain the operating temperature of the device in the range of $60 \pm 5{ }^{\circ} \mathrm{C}$.

УДК 519.816:004.89

DOI: 10.31563/1684-7628-2019-51-3-106-114

И.Р. Кафиев, П.С. Романов, И.П. Романова, Р.Р. Галиуллин

\section{МЕТОДИКА РАСПОЗНАВАНИЯ НЕЧЕТКИХ СИТУАЦИЙ ПРИ УПРАВЛЕНИИ СЕЛЬСКОХОЗЯЙСТВЕННЫМИ МОБИЛЬНЫМИ РОБОТАМИ}

\section{Ключевые слова: мобильный робот; сельское хозяйство; распознавание ситуаций; нечеткая ситуация; ситуационное управление.}

Введение. Сегодня с помощью мобильных роботов в сельском хозяйстве решается ряд задач: вождение тракторов, комбайнов и другой сельхозтехники; подготовка почвы в теплицах, высев семян, опрыскивание химикатами, сбор готовой продукции (рассады, овощей, фруктов), ее сортировка и укладка в тару; разгрузка, погрузка, хранение и распределение сельхозпродукции на складах, в хранилищах и других пунктах агропромышленной логистики $[1,2]$.

Обычно это интеллектуальные роботы (ИР) с автономной системой навигации и передвижения, действующие в неопределенной окружающей обстановке, с управлением от оператора. В ИР технологии искусственного интеллекта (ИИ) применяют не только в системах управления (для управления собственно роботами), но и для выполнения других задач, таких как обработка сенсорной информации, формирование моделей внешней среды, оценка ситуаций и принятие решений, диалог с оператором [1, 3-7].
Планирование поведения мобильных ИР состоит из этапов: выбор стратегии исполнения задачи; формирование совокупности действий; оперативная корректировка поведения с учетом изменений окружающей обстановки. Предложенная в [7] интеллектуальная система управления (ИСУ) мобильным роботом (МР) учитывает последовательные этапы своего поведения: наблюдение (восприятие), оценивание, принятие решений, управление роботом, прогнозирование дальнейшего поведения, самообучение, которые предполагают различные уровни реализации: от простейших сенсомоторных реакций системы до качественных оценок на основе «здравого смысла».

Надо отметить, что хотя при описании модели многоуровневой ИСУ мобильным роботом больше обсуждалось оптимальное управление движением робота, но модель также призвана решать все задачи, стоящие и возникающие перед ИСУ по управлению мобильным роботом и 
его подсистемами. Так, одной из важных задач управления мобильным роботом является распознавание и оценка текущей ситуации. При этом решения принимаются в зависимости от уровня определенности, полноты и точности информации о ситуации и ее оценки: на первом уровне ИСУ принимаются решения по однозначным ситуациям, на втором - по неоднозначным четким ситуациям, на третьем уровне ИСУ МР принимает решение при неоднозначных нечетких ситуациях. Значения и направления перемещений МР выбираются исходя из требований предотвращения столкновений с другими объектами (в том числе и подвижными) окружающей обстановки. При этом чем более неопределенная информация о состоянии мобильного робота и внешней среды, тем выше уровень ИСУ роботом, на котором решается задача по управлению им $[7,8]$.

Таким образом, разработка методики распознавания и оценки текущей ситуации для адекватного реагирования МР на возникающие ситуации для управления МР сельскохозяйственного назначения является актуальной задачей.

Цель исследования. Необходимо разработать методику распознавания и оценки текущей ситуации для совершенствования управления сельскохозяйственным мобильным роботом (MP) в сложных динамических условиях, когда имеют место неполнота и неточность исходных данных, т. е. неопределенность, затрудняющая применение точных численных методов и подходов для описания технологических процессов выполнения сельскохозяйственных работ, например, управление движением робототехническим средством (беспилотным трактором) при вспашке поля или прополке грядок $[1,2,9]$.

Условия, материалы и методы исследования. Ввиду сложности или невозможности формализации задач управления их решение предполагается проводить с привлечением методов искусственного интеллекта.

Состояния, в которых может находиться объект управления, оценивают по значениям признаков. Совокупность типовых ситуаций в основном полно описывает все состояния объекта управления при условии, что при этом учтены особенности управления им. Но все особенности управления объектом учесть не представляется возможным из-за их непредсказуемости [8].

Так, например, робот, предназначенный для прополки сорняков (типа робота HortiBot), при движении по полю должен учитывать рельеф, влажность почвы, расположение грядок и про- чие особенности поля, погодные условия; при выполнении технологической операции прополки ему необходимо определять тип растений, находящихся на том или ином участке поля, отнести их по совокупности качественных характеристик к культурным или к сорнякам и т. П. Итак, имеет место неполнота и неточность исходных данных, следовательно, есть неопределенность, затрудняющая использование численных методов и подходов в описании типовых ситуаций при использовании данного робота $[1,2]$.

Проведенный анализ показал, что признаки, характеризующие сложные объекты управления сельскохозяйственного назначения, могут быть различной природы: вероятностные, детерминированные, логические, качественные. Но вся совокупность состояний объекта управления сельскохозяйственного назначения можно задать комплектом типовых ситуаций. Притом каждая ситуация представляется в виде совокупности лингвистических переменных. Это обусловлено рядом причин. Во-первых, люди при управлении сложными техническими системами, в том числе сельскохозяйственными МР, используют знания из различных областей, часто ориентируются на интуицию и свой предыдущий опыт, которые при создании модели управления и при описании типовых ситуаций человеку легче дать в неформализованном виде, в форме качественных данных: человек мыслит, прежде всего, в «качествах». Во-вторых, качественное, лингвистическое описание значений признаков, как указывается в [9-11], позволяет сократить число типовых ситуаций более чем на два порядка. Втретьих, человеку удобнее вести диалог с ЭВМ в лингвистической форме [8].

Поэтому для распознавания ситуаций в ИСУ MP предлагается подход, основанный на нечетком ситуационном управлении объектами, описанный в $[9,10]$.

Одним из базовых понятий нечеткого ситуационного управления является термин «нечеткая ситуация».

Нечеткой ситуацией называется совокупность нечетких значений признаков, характеризующих состояние объекта. Набор нечетких ситуаций почти совпадает с комплектом типовых ситуаций.

Формально нечеткую ситуацию определяют следующим образом [9]. Есть множество признаков $Y=\left\{y_{1}, y_{2}, \ldots, y_{p}\right\}$, значениями которых характеризуются состояния объекта при управлении им. Признак $y_{i}(i \in I=\overline{1, p})$ определяется лингвистической переменной $\left\langle y_{i}, T_{i}, D_{i}\right\rangle$, где 
$T_{i}=\left\{T_{1}^{i}, T_{2}^{i}, \ldots, T_{m_{i}}^{i}\right\}$ - терм-множество лингвистической переменной $y_{i}$ (совокупность лингвистических значений признака $y_{i}, m_{i}-$ число значений $\left.y_{i}\right) ; D_{i}-$ универсальное множество $y_{i}$. Сами термы $T_{j}^{i}\left(j \in L=\overline{1, m_{i}}\right)$ (для каждого признака $y_{i}$ ), заданы с помощью нечетких переменных вида $\left\langle T_{j}^{i}, D_{i}, \widetilde{C}_{j}^{i}\right\rangle$, что означает, что значение $T_{j}^{i}$ определяется нечетким множеством $\widetilde{C}_{j}^{i}$ в универсальном множестве $\left.D_{i}: \widetilde{C}_{j}^{i}=\left\{\mu_{C_{j}^{i}}(d) / d\right\rangle\right\} . d \in D_{i}$ [9].
Определение 1. «Нечеткой ситуацией $\tilde{s}$ называется нечеткое множество второго уровня» [9]

$$
\widetilde{s}=\left\{\left\langle\mu_{s}\left(y_{i}\right) / y_{i}\right\rangle\right\}, y_{i} \in Y,
$$

где $\mu_{s}\left(y_{i}\right)=\left\{\left\langle\mu_{\mu_{s}\left(y_{i}\right)}\left(T_{j}^{i}\right) / T_{j}^{i}\right\rangle\right\}, j \in L, i \in I$.

Другим важным понятием нечеткого ситуационного управления является «степень нечеткого равенства».

Определение 2. «Степень нечеткого равенства $\mu\left(\tilde{s}_{i}, \tilde{s}_{j}\right)$ ситуаций $\tilde{s}_{i}$ и $\tilde{s}_{j}$ определяется выражением» [9]:

$$
\begin{gathered}
\mu\left(\widetilde{s}_{i}, \widetilde{s}_{j}\right)=\underset{y_{l} \in Y}{\&} \mu\left(\mu_{s_{i}}\left(y_{l}\right), \mu_{s_{j}}\left(y_{l}\right)\right), \\
\text { где } \mu\left(\mu_{s_{i}}\left(y_{l}\right), \mu_{s_{j}}\left(y_{l}\right)\right)=\underset{T_{k}^{l} \in T_{l}}{\&} C\left(\mu_{\mu_{s_{i}}\left(y_{l}\right)}\left(T_{k}^{l}\right), \mu_{\mu_{s_{j}}\left(y_{l}\right)}\left(T_{k}^{l}\right)\right), \\
C\left(\mu_{\mu_{s_{i}}\left(y_{l}\right)}\left(T_{k}^{l}\right), \mu_{\mu_{s_{j}}\left(y_{l}\right)}\left(T_{k}^{l}\right)\right)=\left\{\begin{array}{c}
\mu_{\mu_{s_{i}}\left(y_{l}\right)}\left(T_{k}^{l}\right) \leftrightarrow \mu_{\mu_{s_{j}}\left(y_{l}\right)}\left(T_{k}^{l}\right), \text { если } \mu_{\mu_{s_{i}}\left(y_{l}\right)}\left(T_{k}^{l}\right) \notin(1-t, t) u \\
\mu_{s_{s_{j}}\left(y_{l}\right)}\left(T_{k}^{l}\right) \notin(1-t, t) ; \\
1, \text { если } \mu_{\mu_{s_{i}}\left(y_{l}\right)}\left(T_{k}^{l}\right) \in(1-t, t) \text { или } \mu_{\mu_{s_{j}}\left(y_{l}\right)}\left(T_{k}^{l}\right) \in(1-t, t) .
\end{array}\right.
\end{gathered}
$$

Процесс оценки нечетких ситуаций можно кратко описать следующим образом. Состояние объекта оценивается через заданные отрезки времени и задается в виде нечеткой ситуации. Эта ситуация $\tilde{s}_{0}$ сравнивается со всеми типовыми нечеткими ситуациями $S=\left\{\tilde{s}_{1}, \tilde{s}_{2}, \ldots, \tilde{s}_{N}\right\}$, которые находятся в базе знаний ИСУ МР. В результате сравнения находится типовая нечеткая ситуация, которая больше всего близка входной ситуации. Сведения о ней поступают в ИСУ, где на основе решающей таблицы (форма задания аналогии между типовыми ситуациями и определенным комплектом правил управления объектом) выявляются необходимые в данном состоянии объекта варианты решения. Например, можно использовать модели нечеткого управления на основе алгоритма нечеткого вывода Мамдани, предложенные в [1].

Степень близости нечеткой ситуации $\tilde{S}_{0}$ нечеткой ситуации $\widetilde{s_{i}} \in S(i \in K=\overline{1, N})$ находят с помощью типовых мер близости: степени нечеткого включения $\tilde{S}_{0}$ в $\tilde{S}_{i}$; степени нечеткого равенства $\tilde{s}_{0}$ и $\tilde{s}_{i}$; степени нечеткой общности $\tilde{s}_{0}$ и $\tilde{s}_{i}$. Подбор меры близости зависит от особенностей объекта управления и модели принятия решений по управлению им $[9,10]$.

Результаты исследований. Предлагается следующая методика распознавания ситуаций на основе ситуационной модели управления «ситуация - действие».

1. Создается каталог эталонных ситуаций $S_{S}$. Различие комплекта типовых $S=\left\{\tilde{s}_{1}, \tilde{s}_{2}, \ldots, \tilde{s}_{N}\right\}$ от совокупности эталонных $S_{S}=\left\{\tilde{s}_{1}, \tilde{S}_{2}, \ldots, \tilde{s}_{N}\right\}$ $(n \leq N)$ ситуаций заключается в том, что $S_{S}$ не включает в свою совокупность нечетко равных ситуаций (при заданном пороге равенства). За счет этого размерность системы правил, находящейся в базе знаний ИСУ, снижается, но это не ведет к снижению эффективности модели управления. Считается, что множество $S_{S}$ полно и ситуация $\tilde{s}_{i}$ имеется в базе знаний для любой входной ситуации $\tilde{s}_{0}$. Каждая эталонная ситуация задана согласно определению 1 по формуле (1).

2. Идентифицируется состояние объекта. На данном этапе производится определение входной ситуации. На основе входной информации проводится описание входной ситуации: каждый признак $y_{i}(i \in I=\overline{1, p})$ характеризуется лингвистической переменной $\left\langle y_{i}, T_{i}, D_{i}\right\rangle$, где $T_{i}=\left\{T_{1}^{i}, T_{2}^{i}, \ldots, T_{m_{i}}^{i}\right\}$ - терм-множество лингвистической переменной $y_{i}\left(m_{i}-\right.$ число значений признака); $D$ - универсальное множество признака $y_{i}$. Термы $T_{j}^{i}\left(j \in L=\overline{1, m_{i}}\right)$ признака $y_{i}$, заданы с помощью нечетких переменных $\left\langle T_{j}^{i}, D_{i}, \widetilde{C}_{j}^{i}\right\rangle$, что означает, что значение $T_{j}^{i}$ определяется нечетким множеством $\widetilde{C}_{j}^{i}$ в универсальном множестве $\left.D_{i}: \widetilde{C}_{j}^{i}=\left\{\mu_{C_{j}^{i}}(d) / d\right\rangle\right\}, d \in D_{i}$ (см. определение 1). При этом учитывается, что информация, поступающая в систему, может различаться в зависимости от формы ее описания. Если поступает словесная информация, то описание лингвистическое. В систему может приходить числовая или «аналоговая» информация. Под «анало- 
говой» понимается информация, которая подается на вход в виде непрерывных функций принадлежности нечетких множеств, а затем аналого-цифровые преобразователи видоизменяют ее на векторы степеней принадлежности.

Если поступает числовая информация, то применяют универсальные шкалы значений признаков и функции отображения определенных предметных шкал на универсальные по методикам, описанным в [9].

Когда приходит «аналоговая» информация, то задаются нечеткие множества на предметных шкалах, в последующем эти нечеткие множества линейно отображаются на универсальные шкалы, далее выявляются степени сходства входного множества и термов универсальной шкалы.

При функционировании ИСУ МР следует ожидать, что наиболее часто системе придется оперировать с лингвистической информацией. При поступлении лингвистической информации, соответствующей нечеткой входной ситуации $\tilde{s}_{0}$, для ее описания используются те же признаки, что и для эталонных ситуаций. Степени принадлежности термов устанавливают как числами из отрезка $[0,1]$, так и с помощью слов, которые характеризуют степень соответствия термов характеристикам исследуемого объекта. При этом слова должны соответствовать словам, заложенным в таблицу лингвистических переменных в базу знаний ИСУ МР. Когда по разным причинам какие-либо термы при описании состояния объекта управления не указаны, то их степень принадлежности к входной ситуации берется равной 0,5. Таким образом, на вход подается нечеткая ситуация, возможно, не полностью определенная, т. к. могут быть не указаны степени принадлежности ряда термов значениям определенных признаков.

Экспертная информация об эталонных ситуациях и их соответствии возможным входным ситуациям может быть представлена системой нечетких высказываний вида [12]:

$$
\widetilde{L}=\left\{\begin{array}{c}
\widetilde{L}_{11}:\left\langle\text { если } \widetilde{A}_{1}, \text { mо } r_{11} / \widetilde{B}_{1}\right\rangle \\
\widetilde{L}_{12}:\left\langle\text { если } \widetilde{A}_{2}, \text { mо } r_{12} / \widetilde{B}_{2}\right\rangle \\
\vdots \\
\widetilde{L}_{n m}:\left\langle\text { если } \widetilde{A}_{n}, \text { mо } r_{1 m} / \widetilde{B}_{m}\right\rangle,
\end{array}\right.
$$

где $r_{i j} \in[0,1], i=\overline{1, n, j}=\overline{1, m},-$ степень соответствия $j$-ой эталонной ситуации (высказывания $\left.\widetilde{B}_{j}\right) i$-ой входной ситуации (высказывание $\tilde{A}_{i}$ ); $n, m$ - числа базовых значений лингвистических переменных (число входных и эталонных ситуаций).
3. Распознавание входной ситуации. Здесь входная ситуация сравнивается с эталонными и выявляется эталонная ситуация, которая может быть близка к входной. Для определения степени близости нечеткой входной ситуации $\tilde{s}_{0}$ нечеткой эталонной ситуации, как отмечалось выше, обычно применяют следующие меры близости: степень нечеткого равенства $\tilde{S}_{0}$ и нечеткой ситуации $\tilde{S}_{i}$; степень нечеткого включения $\tilde{s}_{0}$ в $\tilde{s}_{i}$; степень нечеткой общности $\tilde{s}_{0}$ и $\tilde{s}_{i}$.

Исследования [8] показали, что в ИСУ МР для идентификации входной ситуации наиболее эффективно в качестве меры близости применять степень нечеткого равенства, при этом в множество эталонных ситуаций не включаются плохо определенные ситуации. Здесь имеют место два возможных случая.

Первый случай. На вход ИСУ МР приходят ситуации $\tilde{s}_{0}$, которые относительно порога равенства $t$ хорошо установлены. Тогда отношение нечеткого равенства на множестве $S_{1}=S_{S} \cup S_{0}$ есть отношение нечеткой эквивалентности ( $S_{0}-$ множество входных ситуаций). Причем число классов эквивалентности нечеткого разбиения множества $S_{1}$ совпадает с числом эталонных ситуаций, т. к. множество $S_{S}$ не содержит нечетко равных ситуаций. Всякая эталонная ситуация $\tilde{s}_{l} \in S_{S}$ включена в класс эквивалентности $\tilde{A_{l}}$, который соответствует этой ситуации. Класс $\tilde{A}_{l}$, кроме $\tilde{s}_{l}$, содержит все входные ситуации из множества $S_{0}$, нечетко равные $\tilde{s}_{l}$. Таким образом, всякая входная ситуация $\tilde{s}_{0}$ нечетко равна только одной эталонной ситуации $\tilde{s}_{l} \in S_{S}$. Она выявляется сравнением $\tilde{S}_{0}$ с каждой ситуацией $\tilde{s}_{l} \in S_{S} \quad(l \in I=\{1,2, \ldots, n\})$. Нечеткая ситуация $\tilde{s}_{l}$, для которой выполняется условие $\mu\left(\widetilde{s_{0}}, \widetilde{s_{l}}\right) \geq t$, считается равной ситуации $\tilde{s}_{i}$. Здесь $t$ - некоторый порог нечеткого равенства ситуаций $(t \in[0,6 ; 1])$. Если нечеткие значения соответствующих признаков в ситуациях $\tilde{s}_{i}$ и $\tilde{s}_{0}$ нечетко равны (исходя из определения нечеткого равенства нечетких множеств $(\forall y \in Y)\left(\mu_{s_{0}}(y) \approx \mu_{s_{i}}(y)\right)$, то $\tilde{s}_{0} \approx \tilde{s}_{i}$. При этом $\mu\left(\widetilde{s}_{0},{\widetilde{s_{i}}}\right)=\&_{y \in Y} \mu\left(\mu_{s_{0}}(y) \approx \mu_{s_{i}}(y)\right)$.

Второй случай. Поступающие на вход ИСУ ситуации $\tilde{S}_{0}$ плохо определены. Тогда отношение нечеткого равенства на множестве $S_{1}$ есть отношение нечеткой толерантности. Как и в первом случае, количество классов связанного с ним нечеткого покрытия - $n$, любая нечеткая ситуация $\tilde{S}_{l} \in S_{S}$ соответствует классу покрытия $\tilde{A}_{l}$ 
множества $S_{1}$. Но эти классы покрытия могут содержать нечетко непустые пересечения, состоящие из плохо определенных входных ситуаций множества $S_{0}$. Отсюда следует, что плохо распознанная входная ситуация $\tilde{s}_{0}$, возможно, будет нечетко равной нескольким эталонным ситуациям. При этом допустимы два решения:

1) домерить входную ситуацию, т. е. конкретизировать плохо измеренные признаки. На первых этапах решения задачи не рассматриваются плохо определенные признаки входной ситуации $\tilde{s}_{0}$. Идентификация $\tilde{S}_{0}$ проводится на основе оценки признаков, хорошо определенных в этой ситуации. Необходимо учитывать, что уменьшение количества учтенных признаков ведет к увеличению количества типовых ситуаций, которые будут нечетко равны входной ситуации. Это позволяет увеличить вероятность включения типовой ситуации, которую нужно распознать, в совокупность ситуаций для распознавания.

На последующих этапах решения задачи количество типовых ситуаций, которые могут быть нечетко равны входной ситуации, будет сокращаться (в предельном случае до 1) за счет дополнительного измерения входной ситуации $\tilde{S}_{0}$, а точнее доизмерения признаков, которые плохо определены в $\tilde{S}_{0}$. Дальнейшие действия выполняют по первому варианту;

2) определить подмножество эталонных ситуаций $S_{S}$, которые будут нечетко равны $\tilde{s}_{0}$. Полагать ситуацию $\tilde{s}_{i}$, которая имеет максимальную степень равенства с $\tilde{s}_{0}\left(\mu\left(\tilde{s}_{0}, \widetilde{S}_{i}\right)=\right.$ $\left.=\max _{\widetilde{s} \in S_{S}^{0}} \mu\left(\widetilde{s}_{0}, \widetilde{s}_{i}\right)\right)$, наиболее близкой $\tilde{s}_{0}$.

Определение степени нечеткого равенства ситуаций проводят на основании определения 2 по формуле (2). Если полученных ситуаций будет несколько, то решение по выбору той или иной ситуации, наиболее близкой к входной, принимают в зависимости от условий управления объектом.

4. Выдача информации о результатах идентификации входной ситуации в следующий блок ИСУ МР. Передается информация об эталонной нечеткой ситуации, наиболее близкой входной ситуации. Она поступает в ИСУ, где на основе решающей таблицы (форма задания соответствия между всеми возможными ситуациями и некоторым набором вариантов возможных решений задачи) определяются необходимые в данном состоянии объекта варианты решения. Например, как указывалось ранее, можно использовать модели нечеткого управления на основе алгоритма нечеткого вывода Мамдани, предложенные в [1].
Решение методического примера. Необходимо распознать и оценить текущую ситуацию для дальнейшего управления движением мобильного робота сельскохозяйственного назначения. Например, беспилотным трактором (трактором модели New Holland или другим подобным, например, МТ3-82, [13, 14]) при выполнении полевых работ, в частности вспашке поля.

На основе данных, поступающих от подсистемы восприятия мобильного робота (функционально-структурная схема ИСУ МР предложена в [7]), проводится формирование нечетких ситуаций, которые представляют собой совокупность значений признаков, описывающих состояние объекта управления в определенный момент времени. Признаки представляют собой набор внутренних характеристик самого робота и характеристики внешних условий.

Постановка задачи. Управление беспилотным трактором-роботом при выполнении работ описывают тремя признаками:

$y_{1}-$ скорость движения (меняется от 4,5 до 9 км/ч с дискретностью 0,5 км/ч);

$y_{2}$ - расстояние до соседней борозды (от 0,1 до 1 м с дискретностью 0,1 м);

$y_{3}$ - расстояние до гранищь поля (меняется от 5 до 50 м с дискретностью 5 м). Данные по параметрам вспашки поля взяты из [15].

Пусть имеется каталог эталонных ситуаций $S_{S}=\left\{\widetilde{s}_{k}\right\}$, где $\widetilde{s}_{k}=\left\{\left\langle\mu_{s}\left(y_{i}\right) / y_{i}\right\rangle\right\}, y_{i} \in Y$ описывается лингвистической переменной $\left\langle y_{i}, T_{i}, D_{i}\right\rangle\left(T_{i}=\left\{T_{j}^{i}\right\}\right)$, где $\mu_{s}\left(y_{i}\right)=\left\{\left\langle\mu_{\mu_{s}\left(y_{i}\right)}\left(T_{j}^{i}\right) / T_{j}^{i}\right\rangle\right\}$, $j=\overline{1, m_{i}}, k=\overline{1, n}, i=\overline{1, p}$. При создании каталога определены следующие признаки ситуаций:

$y_{1}-$ скорость движения;

$y_{2}$ - расстояние до соседней борозды;

$y_{3}$ - расстояние до гранищь поля.

Заданы базовые множества:

$D_{l}=\{4.5 ; 5.0 ; 5.5 ; 6.0 ; 6.5 ; 7.0 ; 7.5 ; 8.0 ; 8.5 ; 9.0\}$. Скорость движения трактора по полю при вспашке может меняться от 4, 5 км/ч до 9 км/ч через каждые $0,5 \kappa \mathrm{\kappa} /$.

$D_{2}=\{0.1 ; 0.2 ; 0.3 ; 0.4 ; 0.5 ; 0.6 ; 0.7 ; 0.8 ; 0.9 ; 1.0\}$. Расстояние до соседней борозды может принимать значения от 0,1 до 1,0 м через 0,1 м.

$D_{3}=\{5 ; 10 ; 15 ; 20 ; 25 ; 30 ; 35 ; 40 ; 45 ; 50\}$. Pacстояние до границь поля может принимать значения от 5 до 50 м с шагом 5 м.

Терм-множества $T_{i}=\left\{T_{j}^{i}\right\}$ определены следующим образом:

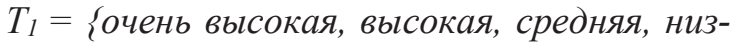
кая, очень низкая $\}$;

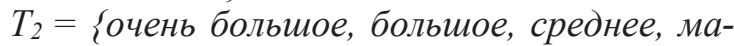
лое, очень малое $;$;

$T_{3}=\{$ очень большое, большое, среднее, малое, очень малое, 
где элементы $T_{j}^{i}$ терм-множеств $T_{i}$ заданы лингвистическими нечеткими множествами (в качестве функций принадлежности взяты стандартные функции принадлежности, полученные в [16]):

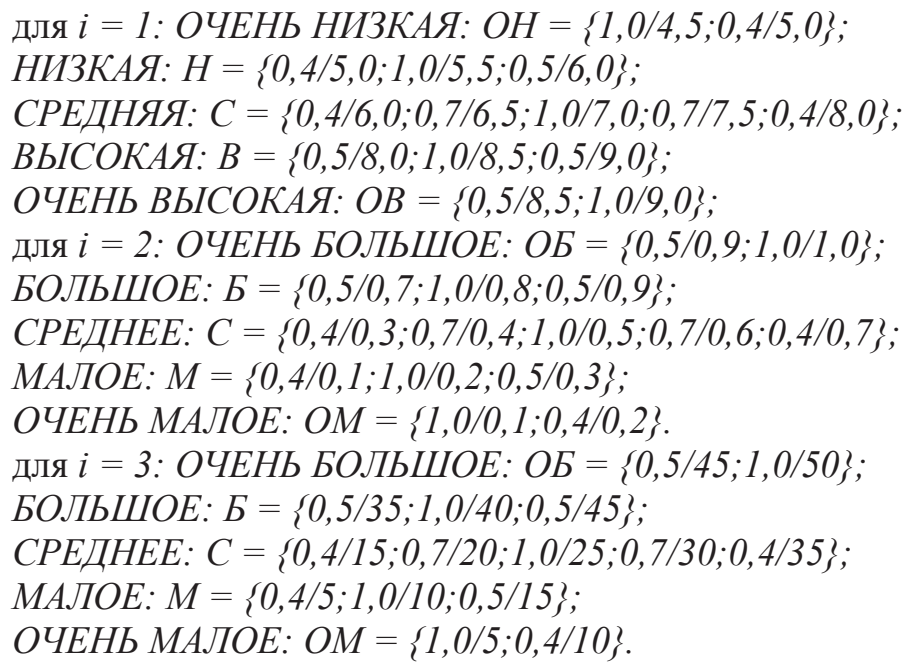

Формальная постановка задачи. На основе входной информации $y_{i}$ и каталога эталонных ситуаций $S_{S}=\left\{\tilde{s}_{k}\right\}, \quad \widetilde{s}_{k}=\left\{\left\langle\mu_{s}\left(y_{i}\right) / y_{i}\right\rangle\right\}, y_{i} \in Y$ идентифицировать входную ситуацию $\tilde{s}_{0}: \tilde{s}_{0} \approx$ $\tilde{s}_{l}, \quad \tilde{s}_{0} \in S_{0}, \widetilde{s}_{l} \in S_{S}$, где $\mu_{s}\left(y_{i}\right)=\left\{\left\langle\mu_{\mu_{s}\left(y_{i}\right)}\left(T_{j}^{i}\right) / T_{j}^{i}\right\rangle\right\}$, $j=\overline{1, m_{i}}, \quad k=\overline{1, n}, i=\overline{1, p}$, при заданном пороге $t \geq 0,7$ и определить положение беспилотного трактора-робота на поле, соответствующее данной ситуации.

Решение задачи.

1. Пусть в каталоге имеется следующая эталонная ситуация $\tilde{s}_{l} \in S_{S}$, которая описывается следующим множеством:

$$
\begin{gathered}
\tilde{s}_{l}=\left\{\left\langle\left\langle 0,7 / T_{1}^{1}\right\rangle,\left\langle 1,0 / T_{2}^{1}\right\rangle,\left\langle 0,8 / T_{3}^{1}\right\rangle,\left\langle 0,4 / T_{4}^{1}\right\rangle,\left\langle 0,1 / T_{5}^{1}\right\rangle / y_{1}\right\rangle ;\right. \\
\left\langle\left\langle 0,9 / T_{1}^{2}\right\rangle,\left\langle 1,0 / T_{2}^{2}\right\rangle,\left\langle 0,7 / T_{3}^{2}\right\rangle,\left\langle 0,2 / T_{4}^{2}\right\rangle,\left\langle 0 / T_{5}^{2}\right\rangle / y_{2}\right\rangle ; \\
\left.\left\langle\left\langle 0,4 / T_{1}^{3}\right\rangle,\left\langle 1,0 / T_{2}^{3}\right\rangle,\left\langle 0,8 / T_{3}^{3}\right\rangle,\left\langle 0,5 / T_{4}^{3}\right\rangle,\left\langle 0,2 / T_{5}^{3}\right\rangle y_{3}\right\rangle\right\} .
\end{gathered}
$$

2. Определена входная ситуация $\tilde{s}_{0} \in S_{0}$, по входной информации $y_{i}$ :

$$
\begin{gathered}
\tilde{s}_{0}=\left\{\left\langle 0,6 / T_{1}^{1}\right\rangle,\left\langle 0,9 / T_{2}^{1}\right\rangle,\left\langle 1,0 / T_{3}^{1}\right\rangle,\left\langle 0,5 / T_{4}^{1}\right\rangle,\left\langle 0,2 / T_{5}^{1}\right\rangle / y_{1}\right\rangle ; \\
\left\langle\left\langle 0,8 / T_{1}^{2}\right\rangle,\left\langle 1,0 / T_{2}^{2}\right\rangle,\left\langle 0,8 / T_{3}^{2}\right\rangle,\left\langle 0,3 / T_{4}^{2}\right\rangle,\left\langle 0,1 / T_{5}^{2}\right\rangle / y_{2}\right\rangle ; \\
\left.\left\langle\left\langle 0,4 / T_{1}^{3}\right\rangle,\left\langle 0,9 / T_{2}^{3}\right\rangle,\left\langle 1,0 / T_{3}^{3}\right\rangle,\left\langle 0,6 / T_{4}^{3}\right\rangle,\left\langle 0,2 / T_{5}^{3}\right\rangle y_{3}\right\rangle\right\} .
\end{gathered}
$$

Данная ситуация приближенно соответствует следующему вербальному описанию: скорость движения трактора-робота - низкая; расстояние до соседней борозды скорее большое, чем среднее; расстояние до границы поля - среднее.
3. Для идентификации входной ситуации определим меру близости нечетких ситуаций. При определении нечеткого равенства двух ситуаций, как было определено ранее, в качестве меры близости используется $\mu\left(\widetilde{s}_{0}, \widetilde{s}_{l}\right) \geq t$.

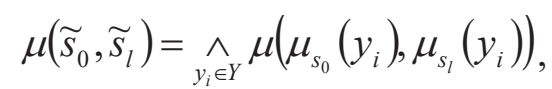

где $\mu\left(\mu_{s_{0}}\left(y_{i}\right), \mu_{s_{l}}\left(y_{i}\right)\right)=\underset{T_{j}^{i} \in T_{i}}{\wedge} c\left(\mu_{\mu_{s_{0}}\left(y_{i}\right)}\left(T_{j}^{i}\right), \mu_{\mu_{s_{l}}\left(y_{i}\right)}\left(T_{j}^{i}\right)\right)$,

$$
c\left(\mu_{\mu_{s_{0}}\left(y_{i}\right)}\left(T_{j}^{i}\right), \mu_{\mu_{s_{l}}\left(y_{i}\right)}\left(T_{j}^{i}\right)\right)=\left\{\begin{array}{l}
\mu_{\mu_{s_{0}}\left(y_{i}\right)}\left(T_{j}^{i}\right) \leftrightarrow \mu_{\mu_{s l}\left(y_{i}\right)}\left(T_{j}^{i}\right), \text { если } \mu_{\mu_{s_{0}}\left(y_{i}\right)}\left(T_{j}^{i}\right) \notin(1-t, t) \text { и } \\
\mu_{\mu_{s_{l}}\left(y_{i}\right)}\left(T_{j}^{i}\right) \notin(1-t, t) ; \\
1, \text { если } \mu_{\mu_{s_{0}}\left(y_{i}\right)}\left(T_{j}^{i}\right) \in(1-t, t) \text { или } \mu_{\mu_{s l}\left(y_{i}\right)}\left(T_{j}^{i}\right) \in(1-t, t) .
\end{array}\right.
$$


для $i=1$ :

$$
\begin{gathered}
\mu\left(\mu_{s_{0}}\left(y_{1}\right), \mu_{s_{l}}\left(y_{1}\right)\right)=c\left(\mu_{\mu_{s_{0}}\left(y_{1}\right)}\left(T_{1}^{1}\right), \mu_{\mu_{s l}\left(y_{1}\right)}\left(T_{1}^{1}\right)\right) \wedge c\left(\mu_{\mu_{s_{0}}\left(y_{1}\right)}\left(T_{2}^{1}\right), \mu_{\mu_{s_{l}}\left(y_{1}\right)}\left(T_{2}^{1}\right)\right) \wedge \\
\wedge c\left(\mu_{\mu_{s_{0}}\left(y_{1}\right)}\left(T_{3}^{1}\right), \mu_{\mu_{s_{l}}\left(y_{1}\right)}\left(T_{3}^{1}\right)\right) \wedge c\left(\mu_{\mu_{s_{0}}\left(y_{1}\right)}\left(T_{4}^{1}\right), \mu_{\mu_{s l}\left(y_{1}\right)}\left(T_{4}^{1}\right)\right) \wedge c\left(\mu_{\mu_{s_{0}}\left(y_{1}\right)}\left(T_{5}^{1}\right), \mu_{\mu_{s_{l}}\left(y_{1}\right)}\left(T_{5}^{1}\right)\right)= \\
=(1) \wedge(0,9 \leftrightarrow 1,0) \wedge(1,0 \leftrightarrow 0,8) \wedge(1) \wedge(1)=0,8 ;
\end{gathered}
$$

для $i=2$ :

$$
\begin{gathered}
\mu\left(\mu_{s_{0}}\left(y_{2}\right), \mu_{s_{l}}\left(y_{2}\right)\right)=c\left(\mu_{\mu_{s_{0}}\left(y_{2}\right)}\left(T_{1}^{2}\right), \mu_{\mu_{s l}\left(y_{2}\right)}\left(T_{1}^{2}\right)\right) \wedge c\left(\mu_{\mu_{s_{0}}\left(y_{2}\right)}\left(T_{2}^{2}\right), \mu_{\mu_{s_{l}}\left(y_{2}\right)}\left(T_{2}^{2}\right)\right) \wedge \\
\wedge c\left(\mu_{\mu_{s_{0}}\left(y_{2}\right)}\left(T_{3}^{2}\right), \mu_{\mu_{s_{l}}\left(y_{2}\right)}\left(T_{3}^{2}\right)\right) \wedge c\left(\mu_{\mu_{s_{0}}\left(y_{1}\right)}\left(T_{4}^{2}\right), \mu_{\mu_{s_{l}}\left(y_{1}\right)}\left(T_{4}^{2}\right)\right) \wedge c\left(\mu_{\mu_{s_{0}}\left(y_{1}\right)}\left(T_{5}^{2}\right), \mu_{\mu_{s_{l}}\left(y_{1}\right)}\left(T_{5}^{2}\right)\right)= \\
=(0,8 \leftrightarrow 0,9) \wedge(1,0 \leftrightarrow 1,0) \wedge(0,8 \leftrightarrow 0,7) \wedge(1) \wedge(1)=0,7 ;
\end{gathered}
$$

аналогично рассчитаем $\mu\left(\mu_{s_{0}}\left(y_{3}\right), \mu_{s_{l}}\left(y_{3}\right)\right)$ для $I=3$ и получим: $\mu\left(\mu_{s_{0}}\left(y_{3}\right), \mu_{s_{l}}\left(y_{3}\right)\right)=0,8$.

Далее рассчитаем $\mu\left(\widetilde{s}_{0}, \widetilde{s}_{l}\right)=\min (0,8 ; 0,7 ; 0,8)=0,7$.

4. Сравним $\mu\left(\tilde{s}_{0}, \tilde{s}_{l}\right)$ с заданным порогом $t$, т. к. $\mu\left(\tilde{s}_{0}, \tilde{s}_{l}\right)=t=0,7$, то делаем вывод о том, что $\tilde{s}_{0} \approx \tilde{s}_{l}$.

5. Выдача информации о результатах идентификации входной ситуации в следующий блок выбора варианта решения ИСУ, где на основе результатов распознавания определяется состояние, в котором находится беспилотный трактор-робот на поле, и производится выбор уровня ИСУ и процедуры решения задачи.

Вывод. Предложена методика распознавания нечетких ситуаций при управлении сельскохозяйственными мобильными роботами, которая позволяет распознавать и оценивать текущую ситуацию в сложных динамических усло- виях, когда имеют место неполнота и неточность исходных данных. Ее применение позволит повысить эффективность управления сельскохозяйственными мобильными роботами в сложных условиях.

Методика основана на нечетком ситуационном управлении объектами, в основе которого лежит ситуационная модель управления «ситуация - действие», предложенная Поспеловым Д.А. Данная методика может быть реализована при проектировании программного обеспечения для управления мобильными роботами сельскохозяйственного назначения и мобильными интеллектуальными роботами, применяемых в других отраслях экономики.

\section{Библиографический список}

1. Кафиев, И.Р. К вопросу нечеткого управления электроприводами сельскохозяйственных интеллектуальных роботов [Электронный ресурс] / И.Р. Кафиев, П.С. Романов, И.П. Романова // Российский электронный научный журнал. 2017. № 4. Режим доступа: journal.bsau.ru/ number4-2017.php. 12.12.2017.

2. Шаныгин, С.В. Роботы как средство механизации сельского хозяйства [Текст] / С.В. Шаныгин // Известия высших учебных заведений. Машиностроение. 2013. № 3. С. 39-42.

3. Интеллектуальные роботы [Текст] / И.А. Каляев, В.М. Лохин, И.М. Макаров, С.В. Манько, М.П. Романов, Е.И. Юревич; под общ. ред. Е.И. Юревича. М.: Машиностроение, 2007. $360 \mathrm{c}$.

4. Костров, Б.В. Искусственный интеллект и робототехника [Текст] / Б.В. Костров, В.Н. Ручкин, В.А. Фулин. М.: Диалог-МИФИ, 2008. 224 c.

5. Линенко, А.В. Нечеткая система управления линейным электроприводом зерноочистительной машины [Текст] / А.В. Линенко,
М.Ф. Туктаров, В.Г. Байназаров // Достижения науки - агропромышленному производству: материалы LV Международной научно-технической конференции. Часть 3. Челябинск: ЮжноУральский государственный аграрный университет, 2016. С. 205-210.

6. Линенко, А.В. Нечеткий регулятор в системе управления линейным электроприводом зерноочистительной машины [Текст] / А.В. Линенко, М.Ф. Туктаров, Ш.Ф. Сираев, В.Г. Байназаров // Электротехнические и информационные комплексы и системы. 2016. Т. 12. № 4. C. 34-40.

7. Романов, П.С. Подходы к созданию интеллектуальной системы управления мобильным роботом [Электронный ресурс] / П.С. Романов, И.П. Романова // Инженерный вестник Дона. 2018. № 1. Режим доступа: ivdon.ru/ru/ magazine/archive/n1y2018/4692.

8. Романов, П.С. Обоснование путей построения автоматизированных систем управления артиллерийскими формированиями на основе новых информационных технологий 
[Текст] / П.С. Романов. Коломна: КГПИ, 2005. $398 \mathrm{c}$.

9. Мелихов, А.Н. Ситуационные советующие системы с нечеткой логикой [Текст] / А.Н. Мелихов, Л.С. Берштейн, С.Я. Коровин. М.: Наука. Гл. ред. физ.-мат. лит., 1990. 272 с.

10. Поспелов, Д.А. Ситуационное управление: теория и практика [Текст] / Д.А. Поспелов. М.: Наука. Гл. ред. физ.-мат. лит., 1986. 288 с.

11. Борисов, А.Н. Принятие решений на основе нечетких моделей. Примеры использования [Текст] / А.Н. Борисов, О.А. Крумберг, И.П. Федоров. Рига: Зинатне, 1990. 184 с.

12. Берштейн, Л.С. Нечеткий логический вывод на основе определения истинности нечеткого правила modus ponens [Текст] / Л.С. Берштейн, А.В. Боженюк // Методы и системы принятия решений. Системы, основанные на зна- ниях: материалы науч. тр. Рига: Риж. политехн. ин-т, 1989. С. 74-80.

13. Самоходные тракторы от New Holland [Электронный ресурс]. Режим доступа: https:// bespilot.com/tip/bespilotnye-traktora. 11.12.2018.

14. Иванов, А. Сельское хозяйство по-умному [Текст] / А. Иванов, В. Моисеев // Control Engineering. Россия IІоТ. Апрель 2017. С. 35-41.

15. Казаков, А.В. Технология проведения вспашки [Текст]: методическое пособие для учебной практики по подготовке трактористовмашинистов сельскохозяйственного производства / А.В. Казаков, В.Ю. Логинов, Д.В. Гутовский, А.Н. Кузьмичев. Н. Новгород: НГСХА, 2013. $59 \mathrm{c}$.

16. Борисов, А.Н. Методы интерактивной оценки решений [Текст] / А.Н. Борисов, А.С. Левченков. Рига: Зинатне, 1982. 232 с.

\section{Сведения об авторах}

1. Кафиев Иршат Рашитович, кандидат технических наук, доцент, доцент кафедры электрических машин и электрооборудования, ФГБОУ ВО Башкирский ГАУ, e-mail: kafiev02@mail.ru.

2. Романов Петр Сергеевич, доктор технических наук, профессор, профессор кафедры автоматизации производства и информационных технологий, Коломенский институт (филиал) ФГБОУ ВО «Московский политехнический университет», e-mail: romanov_p_s@mail.ru.

3. Романова Ирина Петровна, кандидат технических наук, доцент, доцент кафедры виноделия и неорганической аналитической химии, ФГБОУ ВО «Московский государственный университет технологий и управления имени К.Г. Разумовского (Первый казачий университет)», e-mail: i-p-romanova@, yandex.ru.

4. Галиуллин Рустам Рифович, доктор технических наук, заведующий кафедрой электроснабжения и применения электрической энергии в сельском хозяйстве, ФГБОУ ВО Башкирский ГАУ, 450001, г. Уфа, 50-летия Октября, 34, e-mail: rustam6274@mail.ru.

В статье предлагается методика распознавания нечетких текущих ситуаций при управлении сельскохозяйственными мобильными роботами, которая позволяет выявлять и оценивать текущую ситуацию в сложных динамических усло- виях, когда имеют место неполнота и неточность исходных данных. Методика основана на нечетком ситуационном управлении объектами, в основе которого лежит ситуационная модель управления «ситуация - действие».

I. Kafiev, P. Romanov, I. Romanova, R. Galiullin

\section{RECOGNITION METHODS \\ OF FUZZY SITUATIONS TO MANAGE MOBILE ROBOTS IN FARMING}

Key words: mobile robot; agriculture; situation recognition; fuzzy situation; situational management.

\section{Authors' personal details}

1. Kafiev Irshat, Candidate of technical sciences, assistant professor of the Electric Machines and Equipment department, Federal State Budgetary Educational Institution of Higher Education «Bashkir State Agrarian University», Ufa, 50-letiia Oktiabria St., 34, e-mail: kafiev02@mail.ru. 
2. Romanov Petr, Doctor of technical sciences, professor of the Production Automation and Information Technologies department, Kolomna Institute (branch) of «Moscow Polytechnical University», Moscow district, Kolomna, Oktyabr'skaya Revolutsia St., 408, e-mail: romanov_p_s@mail.ru.

3. Romanova Irina, Candidate of technical sciences, assistant professor of the «Winemaking and inorganic analytical chemistry» department, K.G. Razumovsky Moscow State University of technologies and management, 109004, Moscow, Zemlyanoj Val St., 73, e-mail: i-p-romanova@yandex.ru.

4. Galiullin Rustam, Doctor of Technical Sciences, Federal State Budgetary Educational Institution of Higher Education «Bashkir State Agrarian University», 450001 Bashkortostan, Ufa, 50-letiya Oktyabrya St., 34, e-mail: rustam6274@mail.ru.

The paper offers a method to recognize current fuzzy situations in management of mobile robots in farming. It allows to understand and evaluate the current situation in complex dynamic conditions, when there is an incompleteness and inaccuracy of

(с) Кафиев И.Р., Романов П.С., Романова И.П. the original data. The technique is based on fuzzy situational management of objects, which is based on the situational management model «situation action».

УДК 631.348: 631.54

DOI: $10.31563 / 1684-7628-2019-51-3-114-120$

Э.Р. Хасанов, Д.И. Маскулов, Р.3. Мусин

\section{ОБОСНОВАНИЕ ПОКАЗАТЕЛЕЙ КАЧЕСТВА РАБОТЫ СКАРИФИКАТОРА СЕМЯН КОЗЛЯТНИКА}

\section{Ключевые слова: скарификация; скарификатор семян; всхожесть; вращающийся диск; сте- пень скарификации; степень дробления.}

Введение. Важную роль при производстве бобовых культур имеет семенной материал, качество которого, наряду с другими параметрами, определяется всхожестью, на которой неблагоприятно отражается твердая, герметичная оболочка семян, приводящая к затягиванию сроков прорастания всходов, потере части высеянных семян, снижению урожайности [1].

Нарушение герметичности оболочки семян различными способами в процессе подготовки семян к посеву называется скарификацией, а технические устройства, применяемые для данного процесса, - скарификаторами [2].

Кроме семян трав и кормовых культур, различные способы скарификации эффективны для сельскохозяйственных культур - пшеница, овес, ячмень, горох, лук, морковь, шпинат, редис, свекла, петрушка, капуста, томат, кинза, укроп, а также для семян лесных культур [3].

К применяемым на практике способам скарификации семян перед посевом относятся: механическая (физическое воздействие); химическая (обработка кислотой); термическая (прогревание и промораживание). В России и за рубежом существуют различные точки зрения на эффективность и преимущества того или иного способа скарификации.

Ученые Bichoff R.S., de Albuquerque A.N., Mariano D.C. [4] провели полностью рандомизированные исследования с четырьмя повторностями в Бразилии с древесным бобом, скарифицируя его наждачной бумагой (механическая скарификация), погружением в концентрированную $\mathrm{H}_{2} \mathrm{SO}_{4}$ (химическая) и в горячую воду (термическая) в интервале времени 5..20 мин с шагом 5 мин. Наиболее эффективной обработкой в их случае оказалась химическая (20 мин обработки с прорастанием 93,0 \% жизнеспособных семян), наименьшую эффективность показала термическая обработка. К тем же выводам пришли чешские исследователи [5] при скарификации бобовой культуры mucuna-preta и ученые [6], проводившие скарификацию для бобовых культур в условиях Аравийской пустыни в Катаре.

В свою очередь аргентинские исследователи [7], проводившие эксперименты с бобовыми культурами, установили, что наибольшую эффективность на вид T. subterraneum имеет термическая обработка. 
Южноафриканскими [8], американскими [910], индийскими [11] учеными получены данные, говорящие о преимуществах механической обработки. На наш взгляд, химическая и термическая скарификации семян при всех своих достоинствах на производстве применяются редко. При механической скарификации в случае массовой предварительной обработки крупных партий семян при применении технических устройств - скарификаторов, значительно снижающих трудоемкость процесса, возможно добиться требуемого качества обработки с высоким уровнем всхожести семян.

Исследователями Luo J., Sun J., Yang L. [12] создана и апробирована конструкция машины 9BQS-3,0 с пневматическим скарификационным и посевным комплексом, которая неплохо себя зарекомендовала при одновременных операциях скарифицирования и посева семян в Китае. Американскими учеными Lukas S.B., DeFrank J., Baldos O.C. [13] для скарифицирования семян Waltheria indica применялся механический электрический барабанный скарификатор, покрытый наждачной бумагой с зернистостью 80 , обеспечивший всхожесть семян после обработки в течение 15 или 30 сек на 95 и $99 \%$ соответственно. В России также широко применяется механическая скарификация в области сельского и лесного хозяйства, модернизируются действующие скарификаторы и проектируются новые, вводятся параметры для оценки качественных показателей работы скарификатора [14].

Изучив имеющиеся источники литературы, мы провели экспериментальные исследования имеющихся в Республике Башкортостан скарификаторов на семенах бобовых культур, определив, что имеющиеся конструкции несовершенны и обладают рядом недостатков, что подтверждается и другими исследователями: недостаточно высокое качество скарификации [15]; повторные удары у части семян по скарифицирующей поверхности и соответственно их повышенная травмируемость [16]. Кроме того, на производстве часто стоит задача обработки скарифицированных семян бобовых культур микробиологическим препаратом ризоторфин, которая проводится вручную.

Цели исследования: предложить техническое решение, обеспечивающее повышение качества скарификации и последовательно выполняющее две операции - скарификацию и обработку микробиологическим препаратом; произвести оценку технологического процесса.
Условия, материалы и методы исследований. Для исследований предложена конструкция дискового скарификатора (рисунок 1), технологический процесс работы которого следующий. Семена козлятника восточного загружаются в бункер и включается привод. Дозирующим устройством устанавливают подачу семян на вращающийся диск с лопастями, на котором семена двигаются по траектории, близкой к логарифмической спирали, пока не встретятся с лопастью. Лопасти изменяют направление движения семян, при этом возрастает их скорость. Сходя с диска, семена соприкасаются с абразивной поверхностью шлифовального круга, тем самым подвергаются скарификации путем нанесения царапин на твердую оболочку и создания возможности проникновения к зародышам влаги и воздуха. Форма лопастей и их меняющийся угол установки позволяет регулировать угол соприкосновения семян с абразивной поверхностью. После соприкосновения образовавшаяся пыль и примеси от абразивной поверхности шлифовального круга захватываются воздушным потоком вентиляторов (на рисунке не показано) и уходят за пределы установки.

Далее семена подвергаются обработке ризоторфином. Микробиологический препарат из бака по трубопроводу поступает на вращающуюся тарелку. За счет вращения тарелки происходит распыл препарата, который в виде образующихся капель аэрозоля покрывает скарифицированные семена, проходящие вниз. После этого обработанные семена поступают в тару.

При исследовании качественных показателей скарификации семян козлятника при средней влажности $9 \%$ определялись параметры: всхожесть семян, \%; степень скарификации, \% и степень дробления семян, \% при режимах вращения диска 700, 900, 1100, 1300, 1500 об/мин.

В основу методики определения показателей взят способ определения показателей качества работы скарификаторов, предложенный Бурковым А.И., Симоновым М.В., Мокиевым В.Ю [17]. Перед каждым опытом в соответствии с ГОСТ 12036-85 [18] из фракции исходного материала отбирали две навески семян козлятника по 500 г массой каждая. Из первой навески (контроль) и из второй, которую пропускали через скарификатор, отбирали четыре пробы по 100 семян для определения всхожести. Кроме того, из второй навески отбирали среднюю пробу массой 20 г и определяли методом разбора [19] количество в ней дробленых семян. После пересчета на общую массу скарифицированных семян получали массу дробленых семян. 
Степень дробления семян определяли по выражению, \%:

$$
d=\frac{m_{\text {дc }}}{m_{\mathrm{H} 2}} 100
$$

где $m_{\text {дс }}-$ масса дробленых семян во второй навеске, кг; $m_{\mathrm{H}_{2}}-$ масса второй навески, кг.

Для определения всхожести использовали метод проращивания семян между бумагой пробы, характеризующие посевные качества семян до и после обработки соответственно. Для этого по окончании 14 дней подсчитывали количество проросших и твердых (которые к установленному сроку определения всхожести не набухли и не изменили внешний вид) семян.

Всхожесть определяли как (\%):

$$
B=\frac{(\mathrm{B}+K)}{R} 100,
$$

где Б - общее количество семян, проросших по истечении 14 суток; $K$ - количество твердых се- мян, $R$ - количество твердых семян, закладывается в пробе.

За результат анализа принимали среднеарифметическое значение всех проанализированных проб. Если отклонение значений параметра в одной из проб от среднеарифметического значения больше на величину, то всхожесть определяли по результатам анализа оставшихся трех проб. Если такое отклонение имеет еще одна проба, то анализ повторяли.

Степень скарификации определяли как отношение разности количества твердых семян в пробах до и после обработки к количеству твердых семян в пробах до обработки, \%:

$$
C=\frac{K_{1}-K_{2}}{K_{1}} 100
$$

где $K_{1}$ - количество твердых семян в пробе до обработки; $K_{2}-$ количество твердых семян в пробе после обработки.

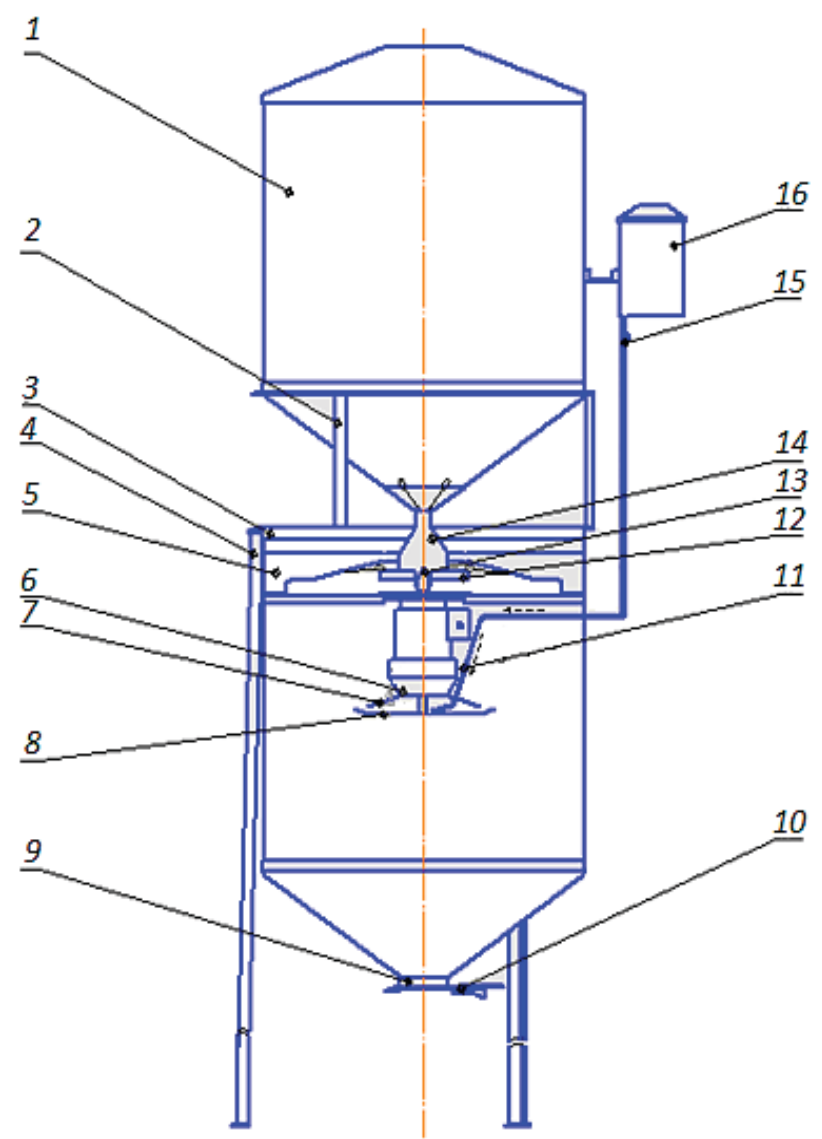

Рисунок 1

Схема экспериментального скарификатора семян: 1 - бункер для семян; 2 - опора; 3 - приемный бункер; 4 - стойка; 5 - абразивная поверхность шлифовального круга; 6 - электродвигатель; 7 - защитный кожух; 8 - тарелка; 9 - выходное окно; 10 - заслонка; 11 - трубопровод; 12 - вращаюшийся диск; 13 - фланец; 14 - конус; 15 - регулировочный кран; 16 - бак с микробиологическим препаратом

Результаты исследования. Для сопоставления экспериментальных данных проведены сравнительные исследования предлагаемого нами скарификатора со скарификатором СКВ-
300 (ФГУП «Уфимское агрегатное производственное объединение»), представленным на рисунке 2 . 


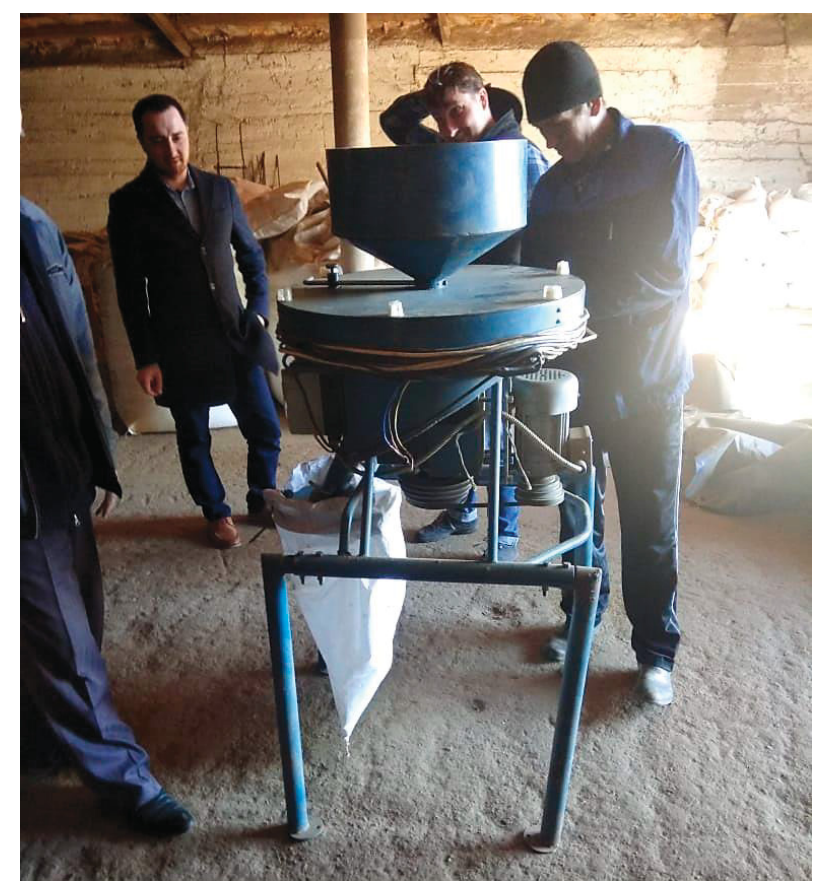

Рисунок 2

Проведение экспериментов

На рисунке 3 приведены полученные данные по всхожести и степени скарификации семян козлятника после обработки на предлагаемом скарификаторе и существующем скарификаторе СКВ-300. Анализ данных по всхожести свидетельствует о том, что качественные показатели работы предлагаемого скарификатора выше, чем у существующего, то же самое наблюдается по показателям степени скарификации. Рекомендуемыми режимами в данном случае является диапазон $900 \ldots 1100$ оборотов диска, при котором степень всхожести семян составит $90 \ldots 91 \%$ без обработки ризоторфином, а степень скарификации - 87...92 \%. Данные степени скарификации семян, представленные на рисунке 1 , говорят о том, что с увеличением количества оборотов и соответственно скорости удара семян об абразивную поверхность (степень шероховатости абразивного круга - 40 мкм), степень скарификации увеличивается с $84 \%$ при 700 об/мин до 98 \% при 1500 об/мин.

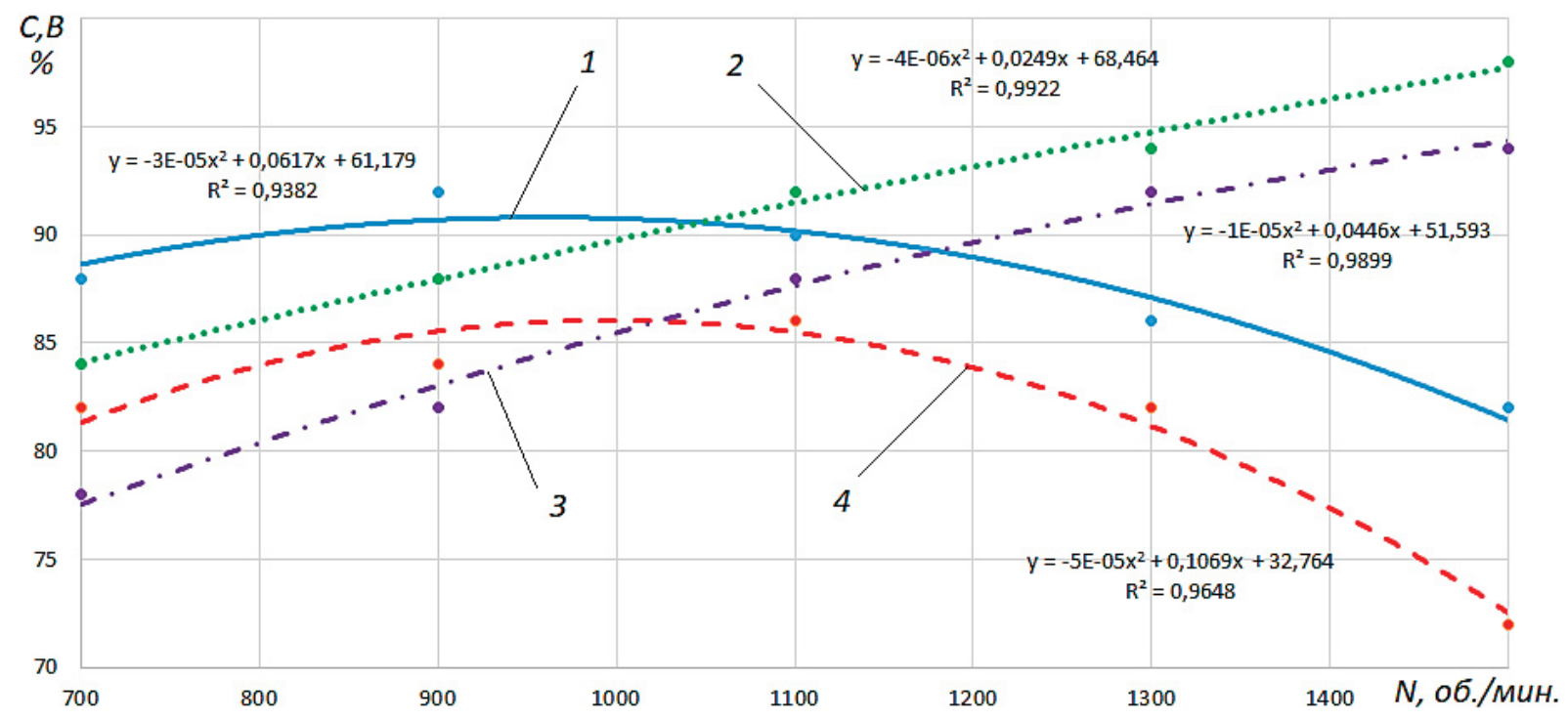

Рисунок 3

Зависимость показателей качества работы предлагаемого и существующего скарификаторов от количества оборотов диска (степень всхожести: 1 - предлагаемого скарификатора, 4 - скарификатора СКВ-300; степени скарификации:

2 - предлагаемого скарификатора, 3 - скарификатора СКВ-300) 
Но вместе с этим увеличивается и степень дробления семян, что является неблагоприятным фактором при обработке (рисунок 4). При рекомендованном выше режиме диапазона обо- ротов диска $900 \ldots 1100$ степень дробления семян составит $1,2 \ldots 2,0 \%$, что допустимо агротехническими нормами.

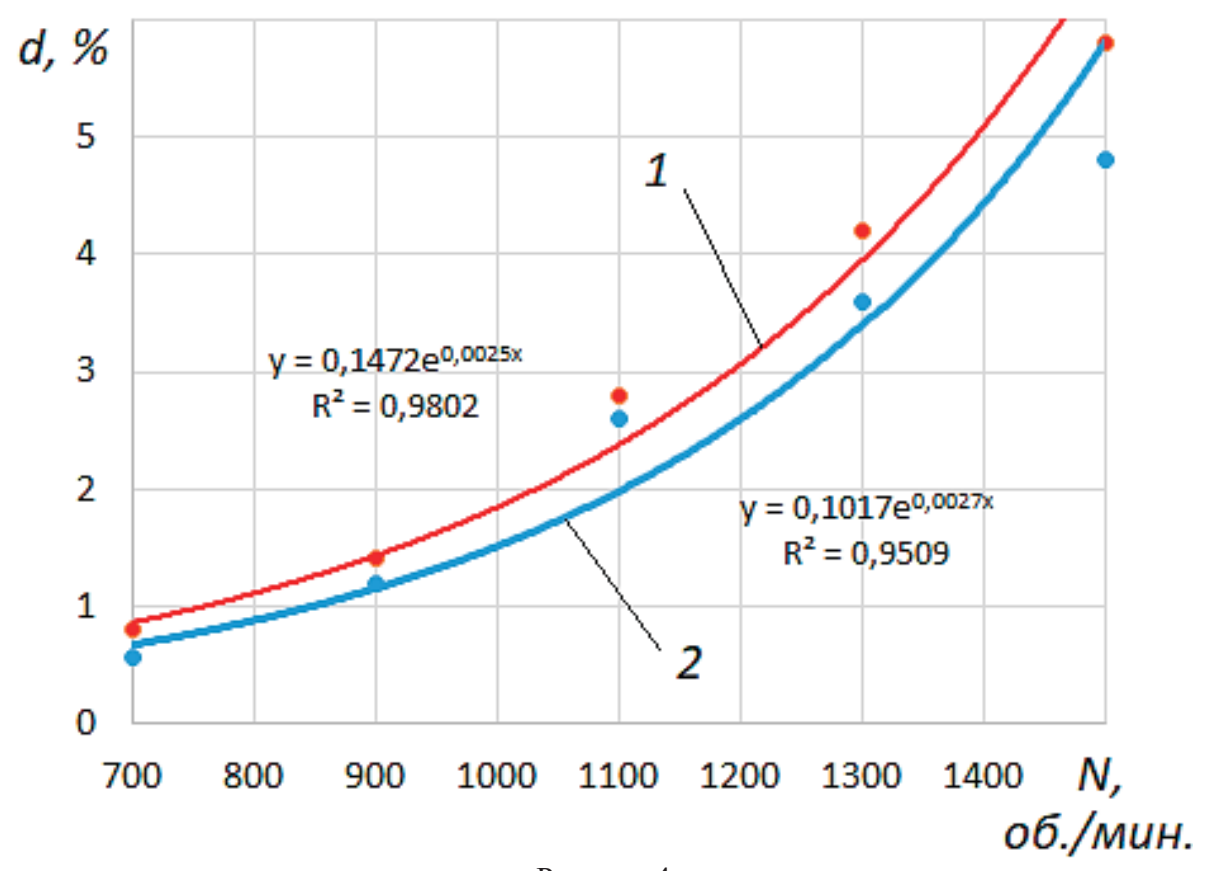

Рисунок 4

Зависимость показателя степени дробления предлагаемого и существующего скарификаторов от количества оборотов диска ( 1 - скарификатора СКВ-300; 2 - предлагаемого скарификатора)

Выводы. В предложенном скарификаторе последовательно выполняются две операции скарификация и обработка микробиологическим препаратом. Применение разработанного устройства для скарификации семян козлятника обеспечила качественную предпосевную обра- ботку семян. В сравнении с существующим скарификатором в рекомендуемом диапазоне оборотов диска 900...1100 предлагаемый скарификатор показал снижение степени дробления семян на $0,2 \ldots 0,4 \%$, повышение степени скарификации на $2 \ldots .3 \%$ и степени всхожести на $4 . . .5 \%$.

\section{Библиографический список}

1. Мокиев, В.Ю. Обоснование конструктивно-технологической схемы и основных параметров вытирающе-скарифицирующего устройства семян трав [Текст]: дис. ... кандидата технических наук / В.Ю. Мокиев. Киров: Зональный научно-исследовательский институт сельского хозяйства Северо-Востока имени Н.В. Рудницкого, 2017. 153 с.

2. Янушко, С.В. Приемы повышения посевных качеств семян бобовых трав [Текст] / С.В. Янушко // Мелиорация. 2010. № 1 (63). C. $187-189$.

3. Куриленко, Н.И. Скарификация семян кедра сибирского [Текст] / Н.И. Куриленко // Актуальные вопросы развития аграрной науки в современных экономических условиях: материалы IV-ой Международной научно-практической конференции молодых учёных. Астрахань: ПНИИАЗ, 2015. С. 112-114.
4. Bichoff R.S., de Albuquerque A.N., Mariano D.C., (...), Sodré D.C., Valente G.F. Overcoming seed dormancy and evaluation of viability in Leucaena leucocephala. Australian Journal of Crop Science, 2018, 12 (1), 68-172.

5. De Oliveira J.D., da Silva J.B., Alves C.Z. Treatments to increase, accelerate and synchronize emergence in seedlings of mucuna-preta. Revista Ciencia Agronomica, 2017, 48 (3), c. 531-539.

6. Bhatt A., Carón M.M., Verheyen K., Elsarrag E., Alhorr Y. Germination and seedling performance of five native legumes of the Arabian Desert. Flora: Morphology, Distribution, Functional Ecology of Plants, 2016, 220, c. 125-133.

7. Mira S., Schnadelbach A., Correa E.C., Pérez-García F., González-Benito M.E. Variability of physical dormancy in relation to seed mechanical properties of three legume species. Seed Science and Technology, 2017, 45(3), c. 540-556. 
8. Müller F.L., Raitt L.M., Cupido C.F., (...), Samuels M.I., Boatwright J.S. Dormancy-breaking treatments in two potential forage crop legumes from the semi-arid rangelands of South Africa. South African Journal of Botany, 2017, 113, c. 133 136.

9. Statwick J.M. Germination pretreatments to break hard-seed dormancy in Astragalus cicer L. (Fabaceae). PeerJ, 2016, (11), e2621.

10. Mirsky S.B., Wallace J.M., Curran W.S., Crockett B.C. Hairy vetch seedbank persistence and implications for cover crop managemen. Agronomy Journal, 2015, 107(6), c. 2391-2400.

11. Nagar R.P., Meena S.S. Effect of physical and chemical scarification and ageing on hardseededness in Clitoria ternatea. Range Management and Agroforestry, 2015, 36(1), c. 79-83.

12. Luo J., Sun J., Yang L., (...), Li W., Dong Z. Design and experiment of type 9BQS-3.0 pneumatic scarifying and sowing compound operation machine. Nongye Jixie Xuebao. Transactions of the Chinese Society for Agricultural Machinery, 2013, 44(SUPPL.1), c. 51-55+66.

13. Lukas S.B., DeFrank J., Baldos O.C. Optimization of Waltheria indica seed dormancy relief treatments and seed storage parameters. Hort Science, 2016, 51(9), c. 1184-1187.

14. Shevchenko A.P., Bankrutenko A.V., Koval V.S., Begunov M.A., Demchuk E.V. Scarification of Seeds as an Increasing Element of Perennial Legume Grasses Productivity. Journal of Physics: Conference Series, 2018, 1059 (1), 012011.

15. Вербовский, А.В. Обоснование параметров и режимов работы дискового скарификатора для предпосевной обработки семян многолетних бобовых культур [Текст]: дис. ... кандидата технических наук / А.В. Вербовский. Новосибирск: Сибирский научно-исследовательский институт механизации и электрификации сельского хозяйства Сибирского отделения Российской академии сельскохозяйственных наук, 2009. $137 \mathrm{c}$.

16. Лукин, А.Н. Параметры пневматического скарификатора для предпосевной обработки семян многолетних бобовых культур [Текст]: дис. ... кандидата технических наук / А.Н. Лукин. Новосибирск: Сибирский научноисследовательский институт механизации и электрификации сельского хозяйства Сибирского отделения Российской академии сельскохозяйственных наук, 2013. 142 с.

17. Способ определения показателей качества работы скарификаторов [Текст]: пат. на изобретение 2564874 РФ, А 01 С1/00 / А.И. Бурков, М.В. Симонов, В.Ю. Мокиев (Россия). № 2014116933/13; заявл. 25.04.2014; опубл. 10. 10.2015, бюл. № 28.

18. ГОСТ 12036-85. Семена сельскохозяйственных культур. Правила приемки и методы отбора проб [Текст]. Введ. 01.07.86. М.: Госстандарт России: Изд-во стандартов, 2011. 13 с.

19. ГОСТ 12037-81. Семена сельскохозяйственных культур. Методы определения чистоты и отхода семян [Текст]. Введ. 01.07.82. М.: Госстандарт России: Изд-во стандартов, 2011. $20 \mathrm{c}$.

\section{Сведения об авторах}

1. Хасанов Эдуард Рифович, доктор технических наук, профессор кафедры сельскохозяйственных и технологических машин, ФГБОУ ВО Башкирский ГАУ, г. Уфа, ул. 50-летия Октября, 34, тел.: (347) 228-08-71, e-mail: hasan_ed@mail.ru.

2. Маскулов Дамир Ильиатович, аспирант кафедры сельскохозяйственных и технологических машин, ФГБОУ ВО Башкирский ГАУ, г. Уфа, ул. 50-летия Октября, 34, тел.: (347) 228-08-71, е-mail: dmaskulov@mail.ru.

3. Мусин Радик Забирович, аспирант кафедры сельскохозяйственных и технологических машин, ФГБОУ ВО Башкирский ГАУ, г. Уфа, ул. 50-летия Октября, 34, тел.: (347) 228-08-71, e-mail: musin-radik @mail.ru.

На основе проведенных исследований создан скарификатор семян, последовательно выполняющий две операции - скарификацию и обработку микробиологическим препаратом. Форма лопастей и их меняющийся угол установки на вращающемся диске позволяет регулировать угол соприкосновения семян с абразивной поверхностью и за счет этого повышать качество обработки. Применение разработанного устройства для скарификации семян козлятника обеспечило качественную предпосевную обработку семян. В сравнении с существующим скарификатором в рекомендуемом диапазоне оборотов диска 900...1100 предлагаемый скарификатор показал снижение степени дробления семян на $0,2 \ldots 0,4 \%$, повышение степени скарификации - на $2 \ldots 3 \%$ и степени всхожести - на $4 \ldots .5 \%$. 


\section{SUBSTANTIATION OF WORK QUALITY INDICATORS \\ OF THE EASTERN GALEGA SEEDS SCARIFICATOR}

Key words: scarification; seeds scarificator; germination; a rotating disk; scarification degree; degree of crushing.

\section{Authors' personal details}

1. Khasanov Eduard, Doctor of technical sciences, professor of the Road Construction, Municipal and Farm Machinery department, Federal State Budgetary Educational Institution of Higher Education «Bashkir State Agrarian University», Ufa, 50-letiya Octyabrya st., 34, e-mail: hasan_ed@mail.ru.

2. Maskulov Damir, Post-graduate of chair of construction and road, municipal and farm vehicles, Federal State Budgetary Educational Institution of Higher Education «Bashkir State Agrarian University», Ufa, 50-letiya Octyabrya str., 34, e-mail: dmaskulov@mail.ru.

3. Musin Radik, Post-graduate of chair of construction and road, municipal and farm vehicles, Federal State Budgetary Educational Institution of Higher Education «Bashkir State Agrarian University», Ufa, 50-letiya Octyabrya str., 34, e-mail: musin-radik@mail.ru.

Based on the studies, a seed scarifier has been created that sequentially performs two operations scarification and treatment with a microbiological preparation. The shape of the blades and their changing installation angle on a rotating disk allows to adjust the angle of contact of the seeds with the abrasive surface and thereby improve the quality of processing. The use of the developed device for scarification of Eastern galega seeds ensured highquality pre-sowing treatment of seeds. Compared with the existing scarifier, in the recommended range of disc speeds of $900 \ldots 1100$, the proposed scarifier showed a decrease in the degree of crushing of seeds by $0,2 \ldots 0,4 \%$, an increase in the degree of scarification by $2 \ldots 3 \%$ and the degree of germination by $4 \ldots . .5 \%$.

(С Хасанов Э.Р., Маскулов Д.И., Мусин Р.3. 


\section{Требования к научным статьям и условия публикации}

Для публикации в научном периодическом (4 номера в год) издании - журнале «Вестник Башкирского государственного аграрного университета» (далее по тексту: Журнал) принимается ранее не опубликованное автором (авторами) произведение по отраслям наук: 05.00.00 Технические науки, 06.00.00 Сельскохозяйственные науки и Ветеринарные науки по группам специальностей: 05.20.00 Процессы и машины агроинженерных систем, 06.01.00 Агрономия, 06.02.00 Ветеринария и Зоотехния. Статья должна быть актуальной, содержать постановку научной задачи (проблемы), описание собственных результатов исследования и состоять из следующих блоков: введение; иель и задачи исследования; условия, материалы и методы исследования; результаты исследования; выводы.

В редакцию авторы предоставляют:

$\checkmark$ Материалы публикации в электронной форме в редакторе Word c расширением *.rtf, оригинал статьи, подписанный авторами - почтой.

$\checkmark$ Отчет о проверке рукописи статьи в программе «Антиплагиат» (www.antiplagiat.ru). При оригинальности работы менее 75 \% она возвращается на доработку.

$\checkmark$ Лицензионный договор с автором(ами) о передаче исключительных прав сроком на 5 лет издательству Башкирского ГАУ. Образец договора, размещенный на сайте Журнала www.vestnik.bsau.ru, заполняется, подписывается автором(ми) в 2-х экземплярах и пересылается в сканированной форме по электронной почте в редакцию Журнала со статьей, а оригиналы договора - почтой.

$\checkmark$ Выписку из протокола заседания кафедры или научного отдела о рекомендации статьи для публикации в Журнале, заверенную подписью и печатью организации

\section{Правила оформления статьи:}

1. Объем статьи 8-15 страниц формата A4, шрифт Times New Roman, размер - 14 кегль, межстрочный интервал - 1,0; абзац - 0,9 см; поля 20 мм со всех сторон.

2. Рисунки, схемы и графики в черно-белом цвете предоставляются в электронном виде, включенными в текст, в стандартных графических форматах с обязательной подрисуночной подписью, и отдельными файлами с расширением *.jpeg, *.tif.

3. Таблицы предоставляются в редакторе Word, шрифт размером - 12 кегль. Формулы и математические символы в тексте набираются в стандартном редакторе формул Microsoft Equation; формулы нумеруются, после формулы приводится расшифровка символов, содержащихся в ней, в том порядке, в котором символы расположены в формуле.

4. На первой странице указываются: индекс по универсальной десятичной классификации (УДК) - слева в верхнем углу; на следующей строке - инициалы, фамилия автора (авторов); на следующей строке - название статьи на русском языке заглавными буквами; на следующей строке - ключевые слова или словосочетания (не менее 5) на русском языке (слова отделяются друг от друга точкой с запятой).

5. Далее по порядку следует текст статьи.

6. В конце статьи оформляется в соответствии с ГОСТ 7.1-2003 библиографический список из 15-20 источников, в т. ч. не менее $50 \%$ ссылок на публикации из периодических изданий - журналов; не менее $30 \%$ ссылок на публикации из peферативных баз Web of Science и (или) Scopus; публикации должны быть не старше 3 лет, допускается не более 10 \% ссылок старше 10 лет. Ссылки на источники в тексте приводятся в квадратных скобках, например [1]; в библиографическом списке приводятся только те источники, на которые есть ссылка в тексте. Самоцитирование - не более $20 \%$.

7. Сведения об авторе (авторах) на русском языке: фамилия, имя, отчество (полностью), ORCID (при наличии), ученая степень, ученое звание, должность, название организации, служебный адрес, телефон, е-таil.

8. Аннотация на русском языке (200-250 слов). НЕ повторяется название статьи. НЕ разбивается на абзацы. Структура аннотации кратко отражает структуру работы. Вводная часть минимальна. Изложение результатов содержит КОНКРЕТНЫЕ сведения (выводы, рекомендации и т. п.). Нежелательно использовать аббревиатуры и сложные элементы форматирования (например, верхние и нижние индексы). Избегайте использования вводных слов и оборотов! Числительные, если не являются первым словом, передаются цифрами. Все русские аббревиатуры передаются в расшифрованном виде, если у них нет устойчивых аналогов в англ. яз. (допускается: ВТО - WTO, ФАО - FАО и т. п.).

9. Инициалы, фамилии авторов на английском языке. При переводе на английский язык недопустимо использование машинного перевода!

10. Название статьи на английском языке.

11. Ключевые слова на английском языке.

12. Сведения об авторе (авторах) на английском языке

13. Аннотация на английском языке.

Материалы в электронном виде необходимо направлять по e-mail: vestnik-bsau@mail.ru. Материалы в печатном виде направляются по адресу: 450001, г. Уфа, ул. 50-летия Октября, 34, каб. 139, редакция Журнала «Вестник Башкирского государственного аграрного университета». Представленные в редакцию рукописи авторам не возвращаются.

Несоответствие представленных материалов по одному из выше перечисленных пунктов может служить основанием для отказа в публикации.

Все рукописи, представляемые авторами для публикации в Журнале, подлежат проверке в системе «Антиплагиат.ВУЗ» для выявления возможных некорректных заимствований с последующим прохождением института рецензирования (экспертной оценки), по результатам чего редакционная коллегия принимает окончательное решение о целесообразности опубликования поданных автором материалов. Информацию о прохождении статьи можно получить по телефону (347) 228-15-11.

Отчет о проверке рукописи статьи в системе «Антиплагиат.ВУЗ» хранится в издательстве в течение срока действия лицензионного договора.

За фактологическую сторону поданных в редакцию материалов юридическую и иную ответственность несут авторы. Редакция оставляет за собой право вносить редакционные изменения и производить сокращение в статье. Корректура статей авторам не предоставляется.

Плата за публикацию статьи в Журнале, в том числе с аспирантов, не взимается.

Подробная информация о журнале и требованиях к статьям размещена на сайте: www.vestnik.bsau.ru. 


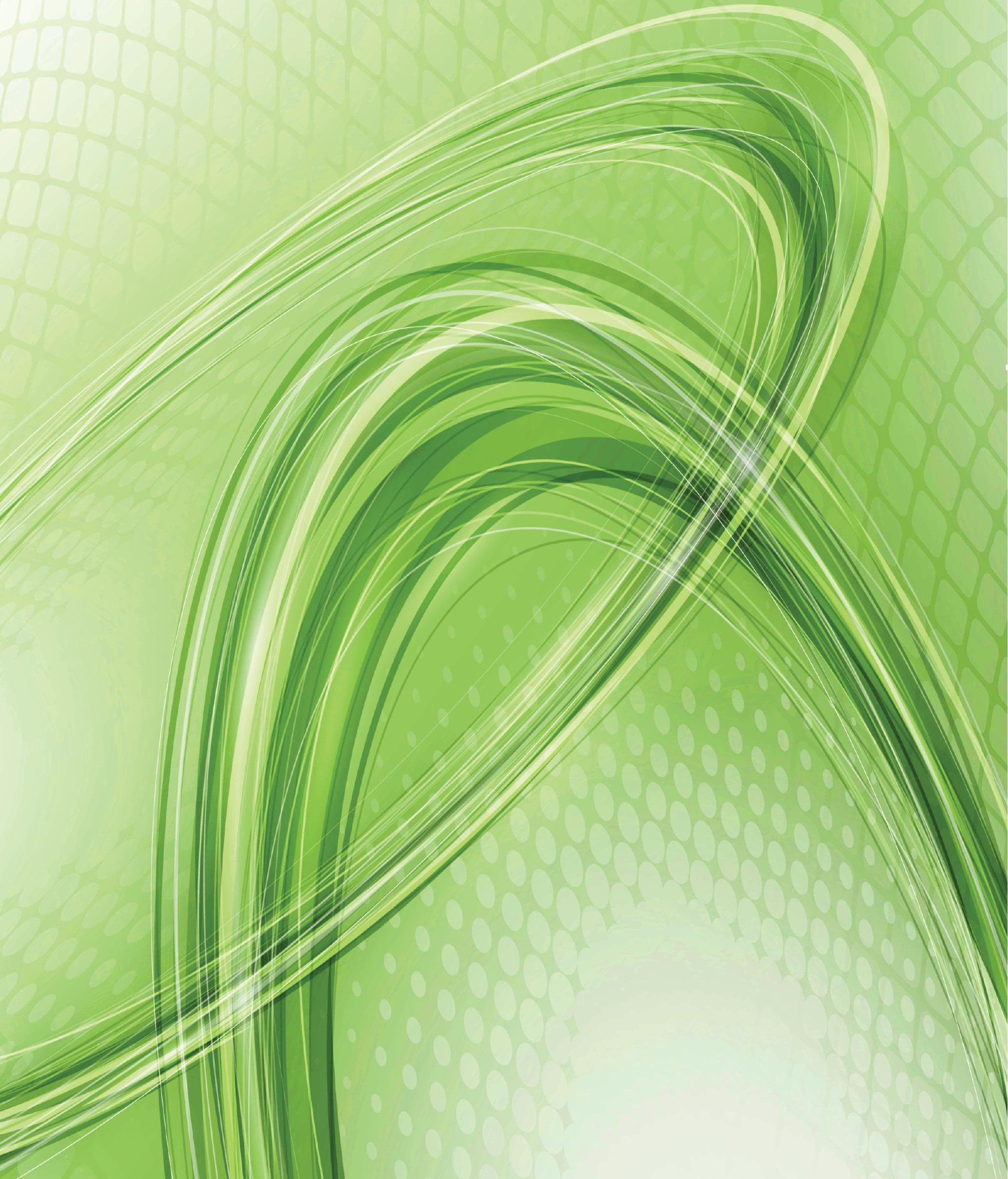

